\title{
GROUND-WATER FLOW AND DISTRIBUTION OF VOLATILE ORGANIC COMPOUNDS, RUTGERS UNIVERSITY BUSCH CAMPUS AND VICINITY, PISCATAWAY TOWNSHIP, NEW JERSEY
}

Water-Resources Investigations Report 99-4256

Prepared in cooperation with RUTGERS, THE STATE UNIVERSITY OF NEW JERSEY 


\section{GROUND-WATER FLOW AND DISTRIBUTION OF VOLATILE ORGANIC COMPOUNDS, RUTGERS UNIVERSITY BUSCH CAMPUS AND VICINITY, PISCATAWAY TOWNSHIP, NEW JERSEY}

By Jean C. Lewis-Brown and Vincent T. dePaul

U.S. GEOLOGICAL SURVEY

Water-Resources Investigations Report 99-4256

Prepared in cooperation with RUTGERS, THE STATE UNIVERSITY OF NEW JERSEY

West Trenton, New Jersey 2000

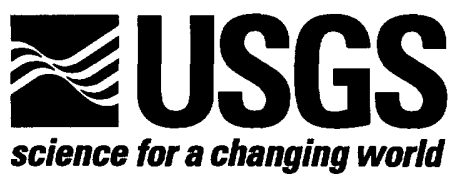




\title{
U.S. DEPARTMENT OF THE INTERIOR \\ BRUCE BABBIT, secretary
}

\author{
U.S. GEOLOGICAL SURVEY \\ Charles G. Groat, Director
}

For additional information write to:

District Chief

U.S Geological Survey Mountain View Office Park

810 Bear Tavern Road

West Trenton, NJ 08628
Copies of this report can be purchased from:

\section{U.S. Geological Survey}

Branch of Information Services

Box 25286

Denver, CO 80225-0286 


\section{CONTENTS}

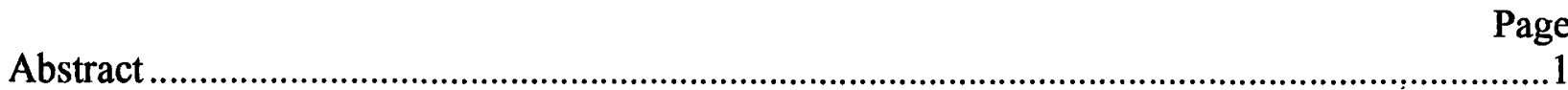

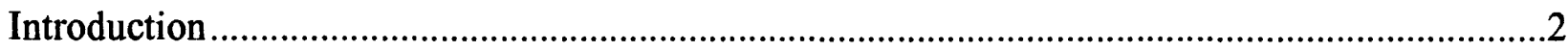

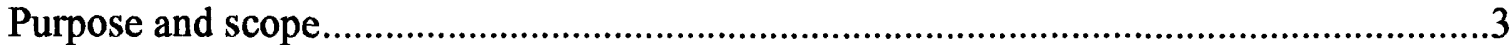

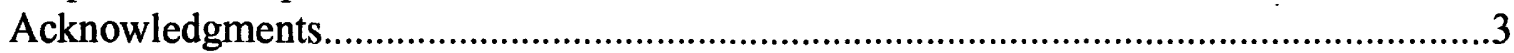

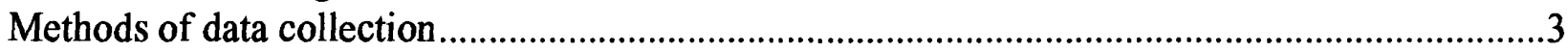

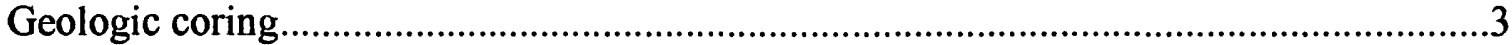

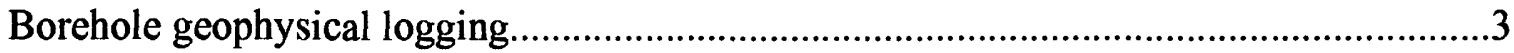

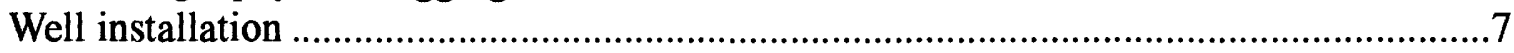

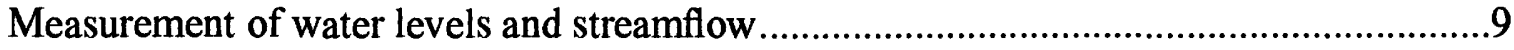

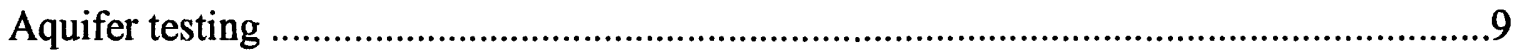

Collection and analysis of water-quality samples ...........................................................10

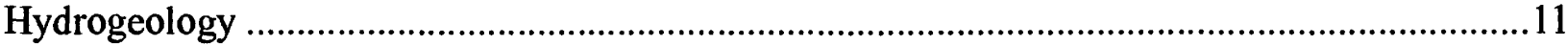

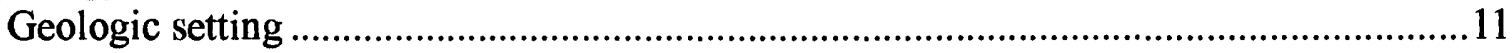

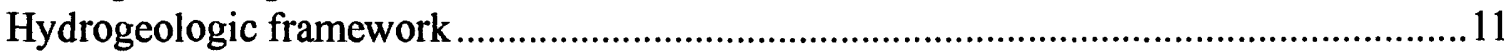

Estimates of hydraulic properties.................................................................................14

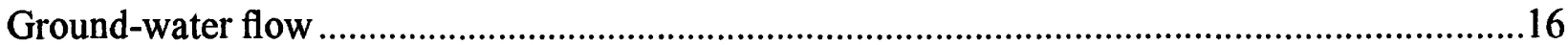

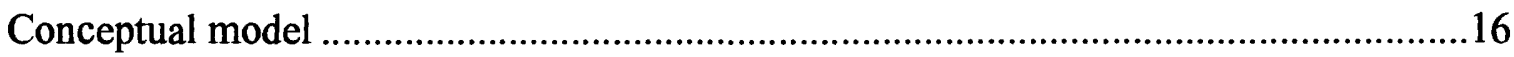

Simulated ground-water flow system...........................................................................18

Description of digital model .............................................................................18

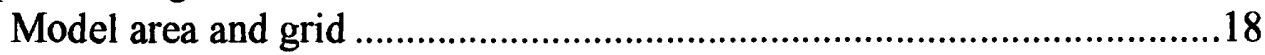

Model boundaries......................................................................................22

Assumptions, limitations, and appropriate uses of the model .....................22

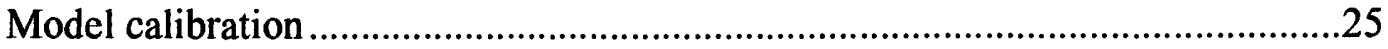

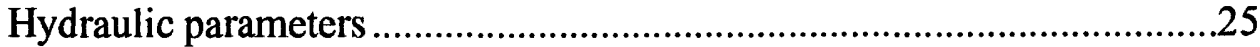

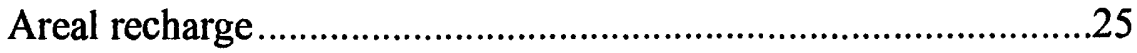

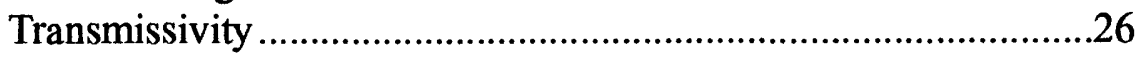

Vertical hydraulic conductivity and vertical leakance ....................27

Streambed hydraulic conductance ................................................28

Specific yield and storage coefficient ..........................................29

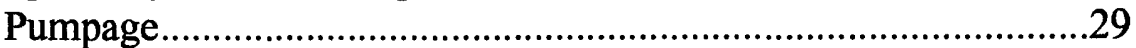

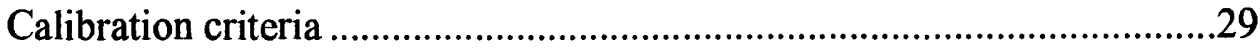

Simulated ground-water budget ...............................................................................31

Ground-water quality and distribution of volatile organic compounds ...........................................31

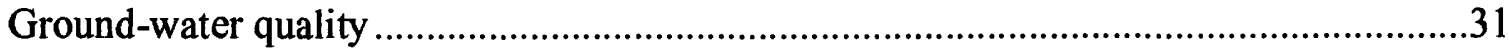

Quality assurance procedures ...............................................................................................

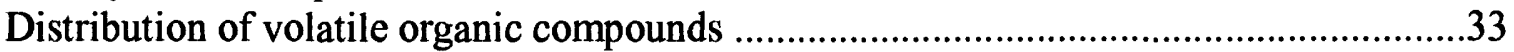

Carbon tetrachloride and tetrachloroethylene .......................................................33

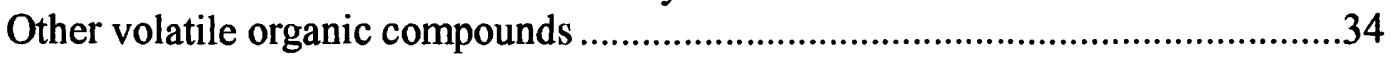

Relation of distribution of contaminants to ground-water flow paths ...................35

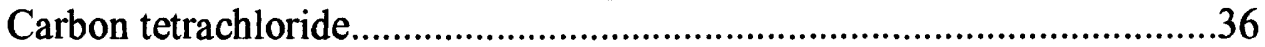

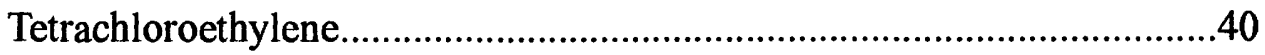

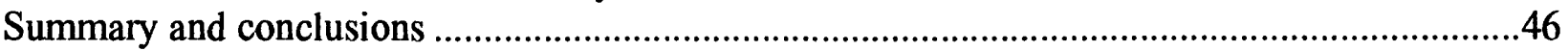

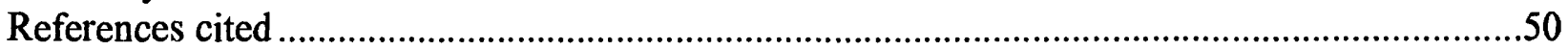




\section{ILLUSTRATIONS}

Figure 1. Map showing location of the study area, Rutgers University Busch Campus and vicinity, Piscataway Township, New Jersey

Page

2. Map showing location of wells and coreholes in the sudy area............

2. Map showing location of wells and coreholes in the study area................................5

3. Generalized section along dip of bedding showing transmissivity measured at wells and interpreted location of hydrogeologic units in the study area...

4. Map of area of ground-water flow model showing horizontal discretization and lines of hydrogeologic section.

5. Section B-B' along strike of bedding showing interpreted hydrogeologic framework in the study area and assumed framework outside the study area in the area of the ground-water flow model.

6. Section C-C' along dip of bedding showing interpreted hydrogeologic framework in the study area and assumed framework outside the study area in the area of the ground-water flow model.

7. Section C-C' showing vertical discretization of ground-water flow model ............23

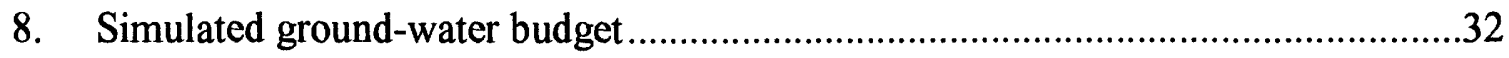

9. Map showing concentration of carbon tetrachloride in water samples collected from wells in 1995 and simulated ground-water flow paths from the assumed carbon tetrachloride source area under steady-state conditions with no pumpage from the irrigation well

10. Map showing concentration of carbon tetrachloride in water samples collected from wells in 1995 and simulated ground-water flow paths from the assumed carbon tetrachloride source area under steady-state conditions with average annual pumpage from the irrigation well.

11. Map showing concentration of carbon tetrachloride in water samples collected from wells in 1995 and simulated ground-water flow paths from the assumed carbon tetrachloride source area under steady-state conditions with maximum pumpage from the irrigation well

12. Section A-A' showing hydrogeologic framework, concentration of carbon tetrachloride in water samples collected from wells in 1995, and simulated area containing ground-water flow paths from the assumed carbon tetrachloride source area under steady-state conditions with no pumpage from the irrigation well

13. Section A-A' showing hydrogeologic framework, concentration of carbon tetrachloride in water samples collected from wells in 1995, and simulated area containing ground-water flow paths from the assumed carbon tetrachloride source area under steady-state conditions with both average annual and maximum pumpage from the irrigation well

14. Map showing concentration of tetrachloroethylene in water samples collected from wells in 1995 and simulated ground-water flow paths from the assumed tetrachloroethylene source area under steady-state conditions with no pumpage from the irrigation well 


\section{ILLUSTRATIONS--Continued}

Page

Figure 15. Map showing concentration of tetrachloroethylene in water samples collected from wells in 1995 and simulated ground-water flow paths from the assumed tetrachloroethylene source area under steady-state conditions with average annual pumpage from the irrigation well

16. Map showing concentration of tetrachloroethylene in water samples collected from wells in 1995 and simulated ground-water flow paths from the assumed tetrachloroethylene source area under steady-state conditions with maximum pumpage from the irrigation well

17. Section A-A' showing hydrogeologic framework, concentration of tetrachloroethylene in water samples collected from wells in 1995, and simulated area containing ground-water flow paths from the assumed tetrachloroethylene source area under steady-state conditions with no pumpage from the irrigation well

18. Section A-A' showing hydrogeologic framework, concentration of tetrachloroethylene in water samples collected from wells in 1995, and simulated area containing ground-water flow paths from the assumed tetrachloroethylene source area under steady-state conditions with both average annual and maximum pumpage from the irrigation well

\section{TABLES}

Table 1. Borehole geophysical logs collected in wells and coreholes at the Rutgers University Busch Campus and vicinity, Piscataway Township, New Jersey

2. Construction information for wells and piezometers at the Rutgers University Busch Campus and vicinity

3. Transmissivity and horizontal hydraulic conductivity at selected wells, Rutgers University Busch Campus and vicinity.

4. Transmissivity in the weathered zone, water-bearing units, and confining units, Rutgers University Busch Campus and vicinity .....

5. Hydraulic parameters used in digital model of ground-water flow, Rutgers University Busch Campus and vicinity.

6. Measured and simulated water levels on October 28, 1996, and drawdown on October 29, 1996, in wells in the study area, Rutgers University Busch Campus and vicinity

7. Concentrations of selected volatile organic compounds in, and chemical and physical properties of, water samples from wells, Rutgers University Busch Campus and vicinity, 1993-96 


\begin{abstract}
APPENDIXES
Page

Appendix 1. Water-level altitudes in wells, Rutgers University Busch Campus and vicinity, Piscataway Township, New Jersey, 1992-96 ..................................................56

2. Volatile organic compounds determined in ground-water samples, Rutgers University Busch Campus and vicinity ..........................................................63

3. Selected chemical constituents in ground-water samples collected at the Rutgers University Busch Campus and vicinity, 1993-94 .64

4. Maximum contaminant levels for selected organic compounds and inorganic constituents, New Jersey

5. Results of analyses of quality-assurance blank samples for selected organic compounds, 1993-96.




\section{CONVERSION FACTORS, VERTICAL DATUM, AND ABBREVIATED WATER-QUALITY UNITS}

Multiply

inch

foot (ft)

mile (mi)

square foot $\left(\mathrm{ft}^{2}\right)$

square mile $\left(\mathrm{mi}^{2}\right)$

gallon (gal)

gallon (gal)

million gallons (Mgal)

cubic foot $\left(\mathrm{ft}^{3}\right)$

foot per day ( $\mathrm{ft} / \mathrm{d})$

cubic foot per second $\left(\mathrm{ft}^{3} / \mathrm{s}\right)$

gallon per minute ( $\mathrm{gal} / \mathrm{min}$ )

million gallons per day (Mgal/d)

degree Fahrenheit $\left({ }^{\circ} \mathrm{F}\right)$

foot per day (ft/d)
By

Length

25.4

0.3048

1.609

Area

0.09294

2.590

Volume

$\begin{array}{cl}3.785 & \text { liter } \\ 0.003785 & \text { cubic meter } \\ 3,785 & \text { cubic meter } \\ 0.02832 & \text { cubic meter }\end{array}$

Flow

0.3048

0.02832

0.06308

0.04381

Temperature

${ }^{\circ} \mathrm{C}=5 / 9 \times\left({ }^{\circ} \mathrm{F}-32\right)$

degree Celsius $\left({ }^{\circ} \mathrm{C}\right)$

Hydraulic conductivity
0.3048

meter per day 


\section{CONVERSION FACTORS, VERTICAL DATUM, AND ABBREVIATED WATER-QUALITY UNITS--Continued}

Multiply

square foot per day $\left(\mathrm{ft}^{2} / \mathrm{d}\right)^{1}$ $\underline{\text { By }}$

Transmissivity

0.09290
To obtain

square meter per day

Vertical datum: In this report "sea level" refers to the National Geodetic Vertical Datum of 1929-a geodetic datum derived from a general adjustment of the first-order level nets of the United States and Canada, formerly called Sea Level Datum of 1929.

Water-quality abbreviations:

$\mathrm{mg} / \mathrm{L} \quad$ - milligrams per liter

$\mu \mathrm{g} / \mathrm{L} \quad$ - micrograms per liter

$\mathrm{mS} / \mathrm{cm}$ - microsiemens per centimeter at 25 degrees Celsius

VOC - volatile organic compound

$\mu \mathrm{m} \quad$ - micrometer

\footnotetext{
${ }^{1}$ This unit is used to express transmissivity, the capacity of an aquifer to transmit water. Conceptually, transmissivity is cubic feet (of water) per day per square foot ( of aquifer area) times feet (of aquifer thickness), or $\left(\mathrm{ft}^{3} / \mathrm{d}\right) / \mathrm{ft}^{2} \times \mathrm{ft}$. In this report, this expression is reduced to its simplest form, $\mathrm{ft}^{2} / \mathrm{d}$.
} 


\title{
GROUND-WATER FLOW AND DISTRIBUTION OF VOLATILE ORGANIC COMPOUNDS, RUTGERS UNIVERSITY BUSCH CAMPUS AND VICINITY, PISCATAWAY TOWNSHIP, NEW JERSEY
}

\author{
By Jean C. Lewis-Brown and Vincent T. dePaul
}

\section{ABSTRACT}

Volatile organic compounds, primarily carbon tetrachloride and tetrachloroethylene (PCE), were detected in shallow ground water near the Chemical Engineering building--also called the $\mathrm{C}$-Wing building--at the Rutgers University Busch Campus in Piscataway Township, Middlesex County, New Jersey. The C-Wing building overlies the Passaic Formation, which comprises a water-supply aquifer, and is about 2,500 feet north-northeast of several domestic wells.

In the area of the Busch Campus, the Passaic Formation consists of dipping layers of extensively fractured coarse-grained siltstone and sandstone alternating with layers of sparsely fractured finer grained siltstone and mudstone. Ground water is primarily stored in and transmitted through interconnected fractures in these rocks. The extensively fractured layers comprise water-bearing units; the sparsely fractured layers comprise confining units. The rock layers dip $11^{\circ}$ to the northwest. Near land surface, the rocks are weathered. Clay and silt derived from the weathering process fills many of the fractures in the weathered zone, causing it to be less permeable than the underlying water-bearing units. Four waterbearing units, alternating with confining units, are present in the study area. The median transmissivity of the water-bearing units and confining units, respectively, is 84 and $3.7 \mathrm{ft}^{2} / \mathrm{d}$ (feet squared per day). The median transmissivity of the weathered zone is $4.8 \mathrm{ft}^{2} / \mathrm{d}$.

Recharge to the ground-water flow system is by downward leakage of infiltrated precipita- tion. The transmissivity contrasts and the dipping hydrogeologic units of the multiunit aquifer system cause large-scale anisotropic flow. Ground-water flow through the system is predominantly southwest, parallel to the strike of the rock layers. Ground-water discharges predominantly to the Raritan River and its tributaries; minor amounts flow to a pumped irrigation well and several domestic wells. The northeastern half of the study area is a recharge area and the southwestern half, which is nearer to the Raritan River, is a discharge area.

A digital model was developed to simulate both steady-state and transient ground-water flow in the study area. The configuration of simulated ground-water flow paths from the vicinity of the $\mathrm{C}$-Wing building are primarily horizontal in the water-bearing units and vertical in the confining units. Horizontal flow generally is parallel or subparallel to the strike of the rock layers. When the irrigation well is not being pumped, all water that passes through the vicinity of the $\mathrm{C}$-Wing building discharges to the Raritan River and its tributaries. Pumping from the irrigation well causes flow lines to shift toward the well and away from the nearby domestic wells.

Water samples were collected from 25 wells in the study area at least once during 1993-96. The spatial distributions of the two primary contaminants at Busch Campus--carbon tetrachloride and PCE--differ from each other. The carbon tetrachloride plume is localized near the $\mathrm{C}$-Wing building, although trace amounts were detected in wells as far as 750 feet from the building. The occurrence of PCE, in contrast, is discontinuous. This compound 
was detected in concentrations greater than the New Jersey maximum contaminant level of 1.0 microgram per liter at several locations in the study area. Concentrations were highest in shallow wells less than 10 feet from the $\mathrm{C}$ Wing building and in the irrigation well, which is 2,370 feet from it. PCE was not detected in samples from nine wells between the C-Wing building and the irrigation well, however.

All wells in which carbon tetrachloride was detected are within the area encompassed by the simulated flow lines from the assumed carbon tetrachloride source area at the C-Wing building, and the concentration of carbon tetrachloride decreases along the flow lines. Therefore, the flow-path analysis supports the hypothesis that all of the carbon tetrachloride detected in the study area originated in the CWing area. Some wells that contained PCE, however, are outside the area encompassed by the flow lines from the assumed PCE source area at the $\mathrm{C}$-Wing building. Consequently, both the simulated flow paths and the discontinuous distribution of PCE are inconsistent with the hypothesis that all of the PCE detected in the study area originated at the broken pipe near the C-Wing building. Because actual ground-water flow paths through the fracturedrock aquifer system are undoubtedly more complex than the simulated paths, however, the possibility that all of the PCE originated at the broken pipe cannot be conclusively ruled out.

\section{INTRODUCTION}

In 1988, during a renovation in the basement of the Chemical Engineering building (hereafter called the C-Wing building) at the Rutgers University Busch Campus, volatile organic compounds (VOC's) were detected in excavated soils surrounding a former laboratory. Concentrations of total VOC's as great as $125,000 \mu \mathrm{g} / \mathrm{L}$ subsequently were detected in ground-water samples collected near the $C$ -
Wing building (ENSR Consulting and Engineering, 1989). The contaminants may have originated from a damaged sump piping system in the basement of the building (ENSR Consulting and Engineering, 1989). This piping system served as a drain for acid wastes and organic solvents used in the C-Wing building. The major compounds identified in the groundwater samples are carbon tetrachloride and tetrachloroethylene (PCE). The C-Wing building overlies the Passaic Formation, which comprises a regional water-supply aquifer, and is about 2,500 ft north-northeast of several domestic wells.

In 1991, the U.S. Geological Survey, in cooperation with Rutgers, the State University of New Jersey, began an investigation of the hydrogeology and extent of contamination in the vicinity of the $\mathrm{C}$-Wing building. The study was conducted in two phases. The first phase, which was conducted during 1991-92, consisted of reconnaissance of contamination in the unsaturated zone and shallow ground water near the $C$-Wing building, including collection and analysis of soil-gas samples, ground-water samples, water-level data, and electrical-resistivity data (dePaul, 1996). In the second phase of the investigation, which was conducted during 1993-97, the study area was expanded to include areas potentially affected by contaminated ground-water flowing from the C-Wing building. This report describes the second phase of the investigation.

The study area is within the Newark Basin, which extends from southeastern New York, through New Jersey, and into Pennsylvania. The Newark Basin comprises a fractured-rock aquifer composed of layered sedimentary rocks. Methods used in this investigation to characterize the hydrogeologic framework and to simulate ground-water flow using a digital model may be applicable to other areas in the Newark Basin where site-specific groundwater flow patterns are of concern. 


\section{Purpose and Scope}

This report describes the hydrogeologic framework, the development of and results of simulations made with a digital model of ground-water flow, and the extent of VOC contamination in the vicinity of the Rutgers University Busch Campus, Piscataway Township, northwestern Middlesex County, New Jersey (fig. 1). The study area comprises $0.3 \mathrm{mi}^{2}$, including parts of the Rutgers University Busch Campus and the Rutgers University Golf Course. Results of field investigations conducted in the study area from May 1993 to October 1996 are presented, including collection of geologic cores, borehole video surveys, and geophysical logs; installation of 19 monitor wells; collection and analysis of water samples from 25 wells; aquifer testing; and measurement of ground-water levels and streamflow.

\section{Acknowledgments}

The authors thank Michael Quinlan and Martin Costello of the Rutgers Environmental Health and Safety Department for providing facilities for the storage of equipment and supplies, coordinating site safety during drilling, and providing equipment for removal of hazardous waste during drilling and sampling. The assistance of Joseph Spang in providing access to the Rutgers University Golf Course also is appreciated. The authors also thank Michael Ayres of Rutgers University Grounds Operation and Facilities Maintenance Services for allowing access to Busch Campus grounds during field work. The assistance of Nicholas Smith and Eric Jacobsen of the U.S. Geological Survey during collection of water samples and installation of monitor wells also is appreciated.

\section{METHODS OF DATA COLLECTION}

Most of the data used in this study were collected in accordance with procedures approved by the U.S. Geological Survey, the U.S. Environmental Protection Agency, or the New Jersey Department of Environmental Protection. Types of data collection for which these agencies have not issued approved procedures were performed according to established practices of the U.S. Geological Survey.

\section{Geologic Coring}

In order to determine the hydrogeologic framework, three coreholes were drilled in the study area. Corehole sites were chosen to encompass sediments overlain by the C-Wing building, while presumably lying outside the contaminant plume (fig. 2). Coreholes $\mathrm{CH}-1$ and $\mathrm{CH}-2$ were aligned approximately along strike; corehole $\mathrm{CH}-3$ was approximately $600 \mathrm{ft}$ downdip from the other two coreholes. The overburden at each site was stabilized by installing temporary casing to 10 or $15 \mathrm{ft}$ below land surface. Continuous 10 - $\mathrm{ft}$ lengths of 2-inch-diameter core were collected at each site by the wireline method. $\mathrm{CH}-1, \mathrm{CH}-2$, and $\mathrm{CH}-$ 3 were cored to 110,100 , and $221 \mathrm{ft}$ below land surface, respectively. Upon removal from the core barrel, the rock cores were placed in wooden boxes and catalogued on site. After all borehole geophysical logs were collected and borehole video surveys were completed, each corehole was sealed with cement grout to land surface.

\section{Borehole Geophysical Logging}

Geophysical logs were collected in nine boreholes in the study area. These logs provide information on the physical characteristics of the formation intersected by the well bore as well as the borehole fluid. The geophysical logs, together with borehole video surveys, were used to help determine the three-dimensional hydrogeologic framework in the study area. A summary of the logs collected in each borehole and the principal application of each $\log$ are presented in table 1. 


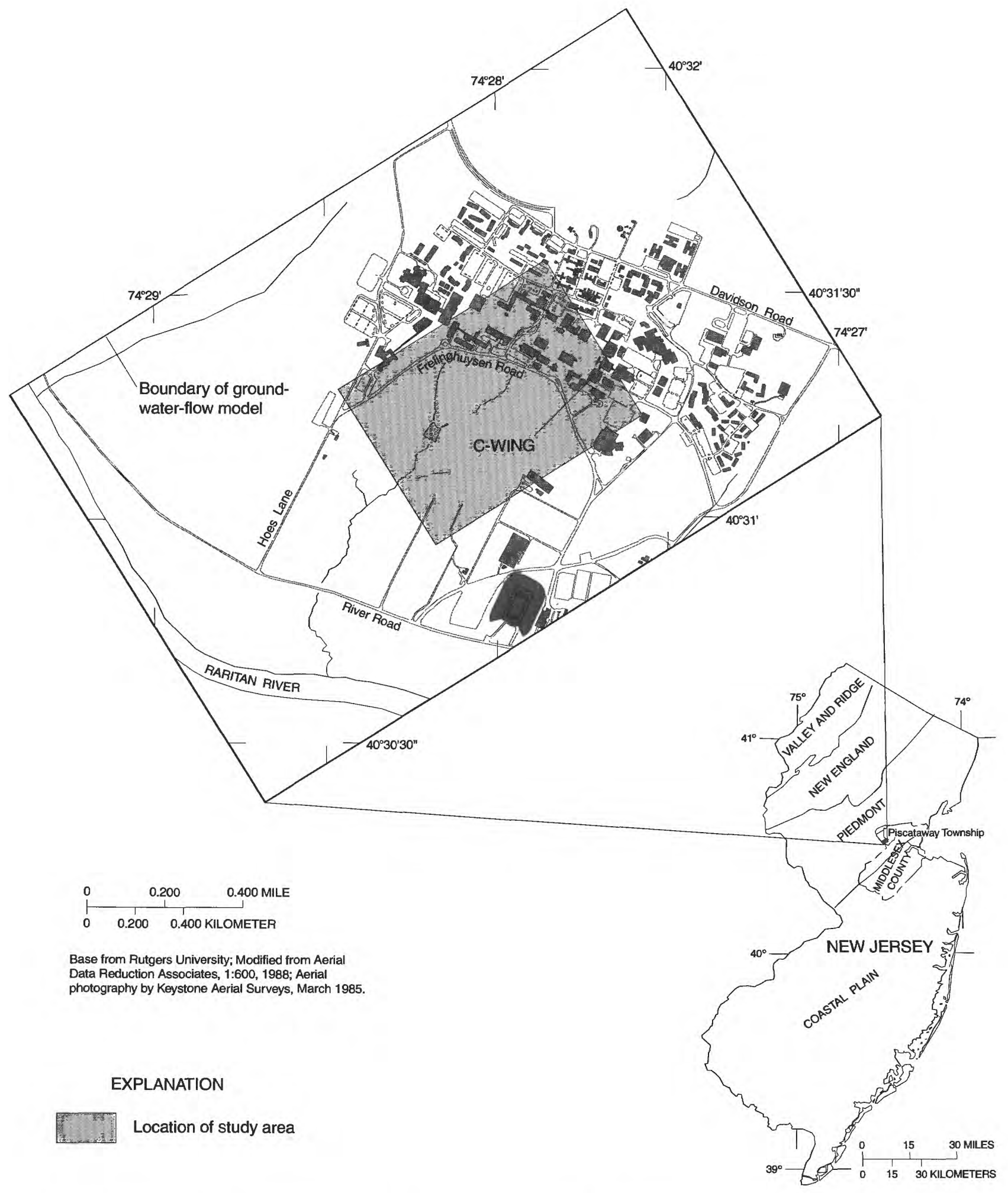

Figure 1. Location of the study area, Rutgers University Busch Campus and vicinity, Piscataway Township, New Jersey. 


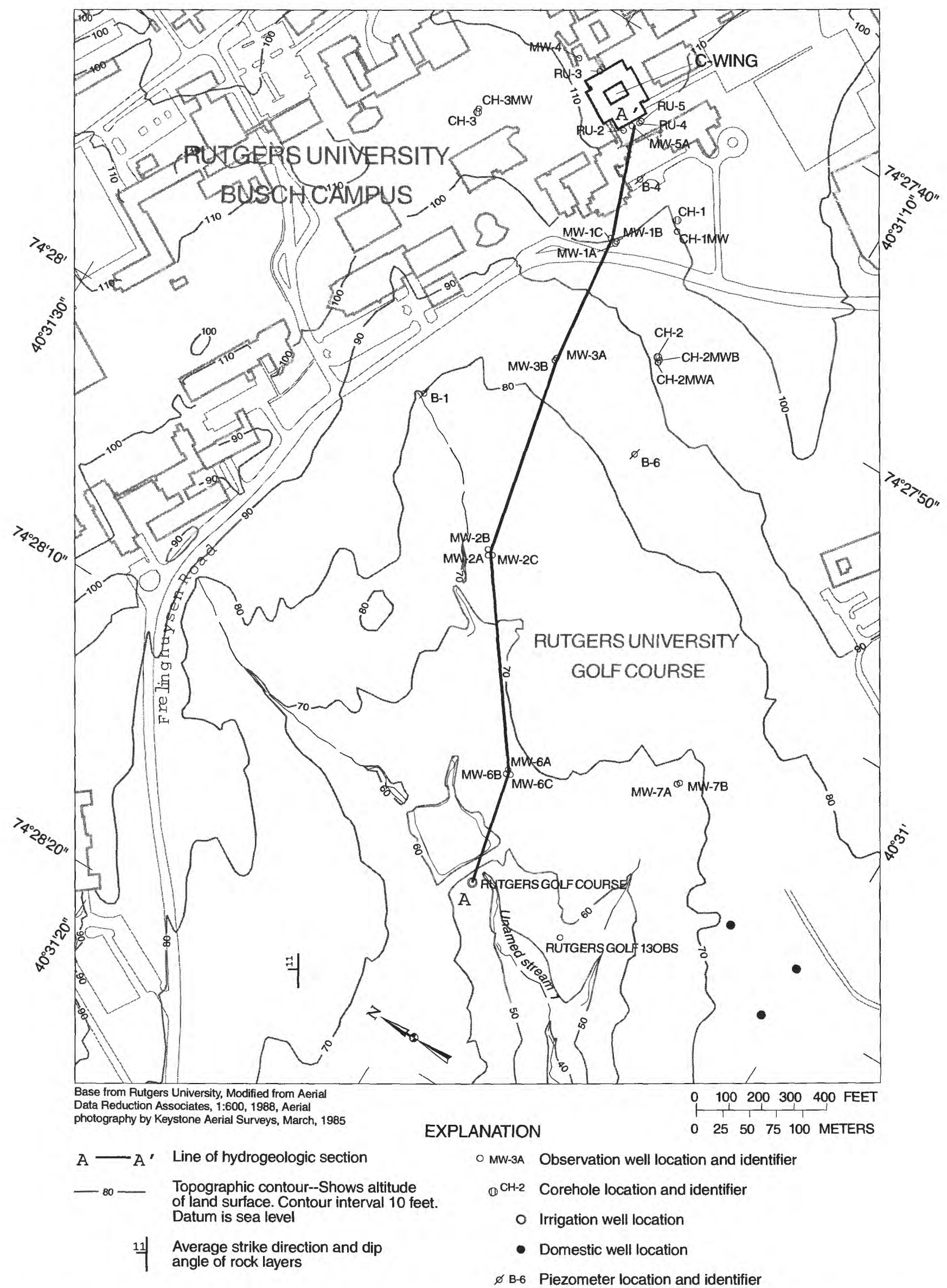

Figure 2. Location of wells and coreholes in the study area, Rutgers University Busch Campus and vicinity, Piscataway Township, New Jersey. 


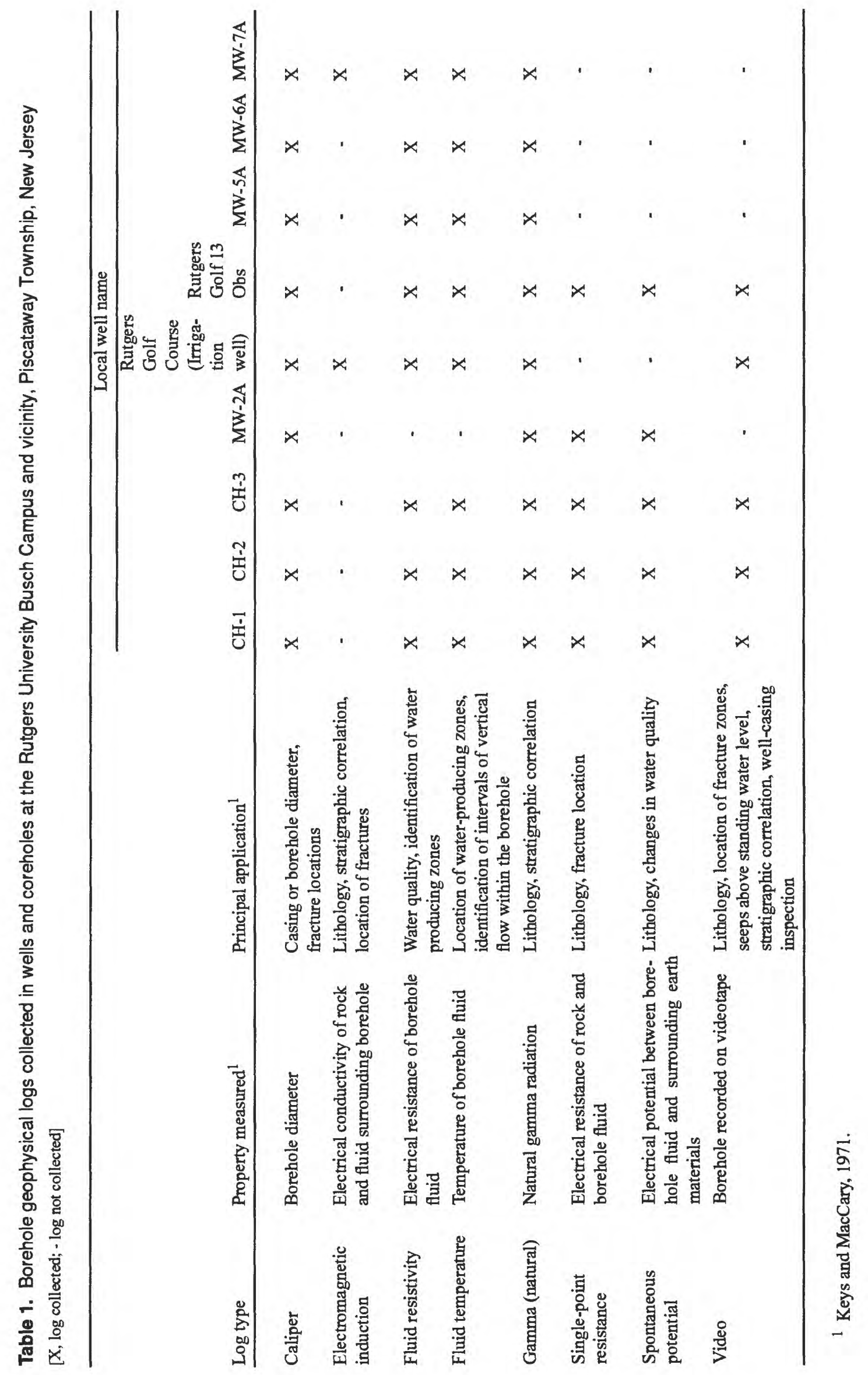




\section{Well Installation}

In order to refine the description of the hydrogeologic framework and to provide a monitor-well network to observe changes in contaminant concentrations and ground-water levels over time, nineteen 4-inch-diameter wells were installed in the study area. Well installation was completed during two phases of drilling from 1993 to 1995 . Six wells and three piezometers that had been installed prior to 1993 also were used during this study. Locations of all wells and piezometers are shown in figure 2. Construction information for all wells and piezometers in the study area is presented in table 2.

During the first phase of drilling, MayJune 1993, 13 wells were installed. Wells were grouped at sites and screened at different depths to facilitate determination of hydraulic characteristics, vertical-flow gradients, and water quality in discrete water-bearing units. Open and screened intervals were selected on the basis of a framework derived from measured strike and dip and previous identification of water-bearing units at well RU-5 (fig. 2). Some well positions and depths were altered during the drilling process as interpretation of new data (geophysical logs and drilling observations) warranted. These monitor wells ranged in depth from 30 to $170 \mathrm{ft}$ below land surface.

Six monitor wells were installed during the second phase of drilling, August-September 1995. A cluster of three wells--MW-6A, MW6B, and MW-6C--was installed approximately $350 \mathrm{ft}$ northeast of the Rutgers Golf Course well (hereafter referred to as the irrigation well) to provide additional information regarding the source and distribution of contaminants near the irrigation well. Open intervals were chosen to intersect three discrete water-bearing units that contribute to the irrigation well. Two wells--MW-7A and MW-7B--were installed approximately $470 \mathrm{ft}$ northeast of the nearest domestic well. This site was chosen to provide a detection point between the $\mathrm{C}$-Wing building and downgradient domestic wells. These wells are open to the same water-bearing units as the nearest domestic well. Well MW-5A was completed between existing monitor wells along the southwestern wall of the C-Wing building in order to provide a deeper sampling point in the area where contaminant concentrations are highest. The monitor wells installed during the second phase of drilling range in depth from 90 to $265 \mathrm{ft}$ below land surface.

All drilling and well construction were performed by private contractors under the supervision of a New Jersey-licensed well driller. The air-rotary method was used. Occasionally, potable water was injected to control dust and to cool the bit until sufficient water was produced in the formation.

Three types of wells were installed. Shallow wells were completed by lowering 4-inchdiameter black carbon-steel casing attached to $10 \mathrm{ft}$ of stainless-steel continuous-slot wirewound screen with 0.020 slotted openings into a nominal 8-inch-diameter borehole. A fine gravel pack was placed around the screen. One to $2 \mathrm{ft}$ of fine-grained sand and then $2 \mathrm{ft}$ of bentonite pellets were placed above the gravel pack to prevent infiltration of the casing seal. The remaining annular space was sealed from the bottom up by pressure grouting through a tremie pipe with either a neat cement slurry or a portland cement/bentonite mixture.

Most deeper wells were completed by installing 4-inch-diameter black carbon-steel casing in a nominal 8-inch diameter borehole from land surface to the top of the proposed open interval. The annular space was sealed with either a neat cement slurry or a portland cement/bentonite mixture as described above. After the annular seal had set, the proposed open interval of the well was drilled through the casing with a 3-7/8-inch bit. No screens were installed in these deeper wells because the bedrock surrounding the open intervals is assumed to be sufficiently competent to preclude collapse of the aquifer material. 
Table 2. Construction information for wells and piezometers at the Rutgers University Busch Campus and vicinity, Piscataway Township, New Jersey

[PVC, polyvinylchloride; SS, stainless steel; W, weathered zone; CU, confining unit]

\begin{tabular}{|c|c|c|c|c|c|c|c|c|c|c|}
\hline $\begin{array}{l}\text { U.S. } \\
\text { Geolog- } \\
\text { ical } \\
\text { Survey } \\
\text { well } \\
\text { number }\end{array}$ & $\begin{array}{l}\text { Local well } \\
\text { name }\end{array}$ & $\begin{array}{l}\text { Latitude } \\
\text { (degrees) }\end{array}$ & $\begin{array}{l}\text { Longi- } \\
\text { tude } \\
\text { (degrees) }\end{array}$ & $\begin{array}{l}\text { Layer } \\
\text { num- } \\
\text { ber }\end{array}$ & $\begin{array}{l}\text { Date of } \\
\text { well } \\
\text { con- } \\
\text { struc- } \\
\text { tion }\end{array}$ & $\begin{array}{l}\text { Altitude } \\
\text { of land } \\
\text { surface } \\
\text { (feet } \\
\text { above } \\
\text { sea } \\
\text { level) }\end{array}$ & $\begin{array}{l}\text { Depth of } \\
\text { screened } \\
\text { or open } \\
\text { interval } \\
\text { (feet } \\
\text { below } \\
\text { land sur- } \\
\text { face) }\end{array}$ & $\begin{array}{l}\text { Dia- } \\
\text { meter } \\
\text { of } \\
\text { screen } \\
\text { or open } \\
\text { Interval } \\
\text { (Inches) }\end{array}$ & $\begin{array}{l}\text { Cas- } \\
\text { ing } \\
\text { mate- } \\
\text { rial }\end{array}$ & $\begin{array}{l}\text { Type of } \\
\text { opening } \\
\text { or } \\
\text { screen } \\
\text { material }\end{array}$ \\
\hline $23-1191$ & B-1 & 403118 & 742757 & w & $11-16-91$ & 79.47 & $14-15$ & .5 & PVC & PVC \\
\hline $23-1190$ & B-4 & 403117 & 742743 & w & $12-17-91$ & 96.14 & $2-4$ & .5 & PVC & PVC \\
\hline $23-1187$ & B-6 & 403112 & 742754 & w & $06-23-92$ & 84.01 & $14-16$ & .75 & PVC & PVC \\
\hline $23-1221$ & CH-1MW & 403115 & 742746 & w & $06-21-93$ & 99.75 & $30-40$ & 4 & Steel & SS \\
\hline 23-1218 & CH-2MWB & 403114 & 742751 & w & $06-28-93$ & 91.31 & $30-40$ & 4. & Steel & SS \\
\hline 251710 & cla & 1493114 & 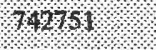 & $4 \%$ & 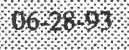 & 6103 & $10 \%$ & 9 & Steerlo & Wowilot \\
\hline 13125 & WHOWW & \%or1 & \% & 9 & $06698 \%$ & $109 \%$ & 140,160 & 4 & sion & oponknow \\
\hline (1) 126 & Wy & 40311 & 14294 & 140 & 606401 & $6 \%$. & 80.100 & w & s.o6) & Vyentido \\
\hline 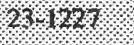 & WWW & 40317 & $14 \% 48$ & $1 \%$ & 606247 & $0 \% 00$ & 120,140 & \% & ortor & 101017016 \\
\hline 1312,8 & 1nuto & 40111 & 142748 & W & $60,24 \% 3$ & $97 \%$ & $30 \%$ & x & sifod & S8 \\
\hline $23-1223$ & MW-2A & 403115 & 742801 & CU9 & $06-24-93$ & 72.80 & $150-170$ & 4 & Steel & Open hole \\
\hline 23-1224 & MW-2B & 403115 & 742801 & 9 & $06-24-93$ & 72.43 & $90-110$ & 4 & Steel & Open hole \\
\hline $23-1225$ & MW-2C & 403115 & 742801 & CU8 & $06-24-93$ & 72.51 & $60-80$ & 4 & Steel & Open hole \\
\hline 23-1229 & MW-3A & 403117 & 742753 & CU9 & $06-25-93$ & 83.16 & $120-140$ & 4 & Steel & Open hole \\
\hline $23-1230$ & MW-3B & 403117 & 742753 & 9 & $06-25-93$ & 83.06 & $70-90$ & 4 & Steel & Open hole \\
\hline 13.125 & WW & 40312 & 14272 & W & $1062^{24} 93$ & 110.84 & $20 \%$ & 4 & story & SS \\
\hline 11260 & Who & 403110 & 4,74 & 11 & $00000 \%$ & $10 \%$ & 170,201 & 箱 & ofoor & ss \\
\hline 60176 & $11 \% 6$ & 100311 & 14080 & m & 6011005 & $65 \%$ & $30 \%$ & 4 & steø & \% \\
\hline $23 \% 1066$ & Ww68 & . & 7.4980 & 1 & 69118.63 & 65 & $100 \%$ & \% & stinel & 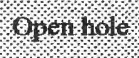 \\
\hline 23146 & 14k60 & 40311 & 142808 & 9 & $09 \% 20 \% 5$ & $65 \% 4$ & 15000 & 4 & ster & Qpontrol \\
\hline $23-1263$ & MW-7A & 403107 & 742805 & 11 & $09-22-95$ & 67.73 & $110-136$ & 4 & Steel & SS \\
\hline $23-1264$ & MW-7B & 403107 & 742805 & 10 & $09-23-95$ & 67.92 & $65-90$ & 4 & Steel & Open hole \\
\hline $23-1184$ & RU-2 & 403118 & 742743 & w & $08-25-88$ & 108.67 & $7-27$ & 4 & PVC & PVC \\
\hline $23-1186$ & RU-3 & 403120 & 742742 & w & $08-25-88$ & 110.93 & $7-27$ & 4 & PVC & PVC \\
\hline $23-1185$ & RU-4 & 403118 & 742743 & w & $08-30-88$ & 107.45 & $7-27$ & 4 & PVC & PVC \\
\hline 20118 & Nut & 40310 & 9487 & 6 & 09006.88 & $10 \%$ & (3) & \% & Wro & W \\
\hline 28.1166 & hulgors gol & 103108 & $7.481 \%$ & 101 & 1062980 & 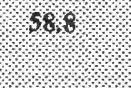 & $30.20 \%$ & 6 & freed & $10 p, 114010$ \\
\hline 6105 & 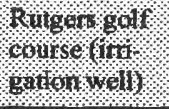 & 403110 & 142812 & 911 & $606=3000$ & $4 \%$ & 5. & 8 & 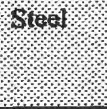 & 10071010 \\
\hline
\end{tabular}


Three of the deeper wells--MW-5A, MW$6 \mathrm{~A}$, and MW-7A--were completed with $25 \mathrm{ft}$ of stainless-steel screen instead of an open hole so that the entire borehole could be geophysically logged at one time. The continuous geophysical logs from these deep boreholes were used to select open intervals of proposed shallower wells at the same sites. A large slot size of 0.10 was used so as not to restrict the natural flow through the fractured bedrock.

Wells MW-1A, MW-1B, and MW-5A were constructed with an 8-inch-diameter outer casing set in a 12-3/4-inch-diameter borehole to 40,40 , and $80 \mathrm{ft}$, respectively. This was done in order to reduce the risk of downward migration of contaminants during drilling.

All wells were finished to land surface with a concrete collar and a water-resistant flush-mounted cover. After completion, wells were developed by surging and pumping with a stainless-steel submersible pump until the water was relatively clear and free of debris. Wells that had low yields--CH-1MW and MW4--were later redeveloped by use of a surge block and a centrifugal pump. Altitudes of land surface and top of casing were surveyed to the nearest hundredth of a foot, and the location was determined to the nearest tenth of a second.

In order to reduce the possibility of introducing foreign contaminants and of cross-contamination during well installation, all well casings and screens were washed with laboratory-grade detergent and potable water, then steam-cleaned inside and out. All other equipment (drill rod, bits, pumps, and hoses) including the drill rig was steam-cleaned prior to use at each site. At sites near the C-Wing building, drill cuttings and borehole water were assumed to be hazardous. The water and cuttings were collected in a portable basin and subsequently removed and placed in containers for testing and proper disposal. At sites farther away from the C-Wing building, drill cuttings and borehole water were not expected to contain significant contamination. Water encountered during drilling was allowed to discharge to the ground in the vicinity of the well. Drill cuttings were removed from the well sites and stockpiled at a location designated by Rutgers University.

\section{Measurement of Water Levels and Streamflow}

Water levels in all wells and piezometers were measured synoptically 12 times during September 1993-October 1996 to determine head gradients and to provide data for calibration of the digital ground-water flow model used in this study. In addition, water levels in each well were recorded during routine site visits. Water-level data are presented in appendix 1 .

Water levels were measured manually with either with a steel or an electric tape that was decontaminated with laboratory soap and deionized water at each well site. The water level in the irrigation well, a flowing artesian well, was measured by attaching a clear plastic extension to a fitting near the well head and measuring the height of the water column above land surface.

On March 13, 1995, and October 28, 1996, base-flow discharge measurements were made on unnamed stream 1. (The location of these measurements is shown in figure 4, farther on.) The measurement was made volumetrically, because all flow was concentrated in two culverts and could easily be diverted into a container. This is the most accurate method for measuring small discharges (Rantz and others, 1982, p. 262).

\section{Aquifer Testing}

Slug tests were chosen as a means of estimating the transmissivity and horizontal hydraulic conductivity of the aquifer because slug tests do not require the handling and disposal of large volumes of potentially contaminated water, and testing can be completed in a 
relatively short period of time. The main limitation of slug tests is that the results can be applied only to a small area surrounding the well and are dependent on well construction in addition to the formation characteristics.

The slug tests were conducted by using a solid polyvinyl chloride (PVC) cylinder that was decontaminated between sites. Water levels were measured by using a 2.5 -psi pressure transducer and a data logger. At each well, several static-water-level measurements were made; then a transducer was placed in the well and allowed to stabilize to water temperature. A static-water-level measurement was then made with the transducer in the well. The PVC cylinder was then quickly lowered into the well, and the decline in water level was measured. Measurements were made at 1-, 2-, or 5 -second intervals on the basis of expected response time for a particular well. The cylinder was then removed and the rise in water level recorded. The static water level was measured again at the end of the test.

\section{Collection and Analysis of Water-Quality Samples}

Water-quality samples were collected from 25 wells in the study area during four rounds of sampling from August 1993 to October 1996. No newly installed monitor wells were sampled until at least 30 days after development. Wells were purged by pumping three to five casing volumes of water whenever possible, and samples were collected after water temperature, $\mathrm{pH}$, specific conductance, and dissolved-oxygen concentration had stabilized to ensure that the sample was representative of aquifer water. For low-yielding wells that were slow to recover, standing water was evacuated at a low pumping rate to the top of the open interval one to two times, then allowed to recover sufficiently before sampling. Well purging at most sites was accomplished by using a variablepumping-rate stainless-steel submersible pump attached to $1 / 2$-inch-diameter polyethylene hose. In shallow wells in which the static water level was less than $20 \mathrm{ft}$ below land surface, a peristaltic pump outfitted with silicone and polyethylene hose was used. All samples except that from the irrigation well were collected with Teflon bailers attached to Tefloncoated stainless-steel wire. Water in the irrigation well was evacuated by using its high-volume pump, and the sample was drawn through a stainless-steel fitting attached to a sampling spigot near the wellhead. Samples to be analyzed for dissolved constituents were filtered in the field with an $0.45-\mu \mathrm{m}$ filter. Immediately following collection, samples were preserved and prepared for shipment to the laboratory.

In order to reduce the potential for crosscontamination during sampling, wells were sampled in ascending order of known or expected total-VOC concentration. The hose used for well purging was flushed with deionized water prior to use and disposed of after one use. Submersible pumps used for purging were decontaminated between uses by an external wash with laboratory-grade detergent and tap water, an internal flush with a detergent-andwater solution, a cold tap-water rinse and flush, and, finally, a deionized-water rinse and internal flush. When pumps were used to purge wells in which total-VOC concentrations were $500 \mu \mathrm{g} / \mathrm{L}$ or greater, the final step was preceded by an external methanol rinse and internal flushing with a methanol/deionized-water solution. In addition, several times during each sampling event, the pumps were disassembled in the laboratory and thoroughly cleaned. Bailers were dedicated to one well per sampling day and returned to the laboratory for cleaning. Bailers and bailer parts were decontaminated by scrubbing with a solution of tap water and laboratory-grade detergent, rinsing with tap water, rinsing with deionized water, rinsing with reagent-grade methanol, purging with pure nitrogen or allowing them to thoroughly air-dry, rinsing with deionized water, and then 
air-drying. Equipment used to collect water to be analyzed for organic constituents was wrapped in aluminum foil; equipment used to collect water to be analyzed for inorganic constituents was sealed in polyethylene until use.

During the initial round of sampling in 1993, purge and equipment-cleaning water from all wells except the irrigation well and Rutgers golf 13 obs was placed in containers. Thereafter, all purge and equipment-cleaning water only from wells known or suspected to have significant contamination was pumped directly into 55-gallon drums for proper disposal.

VOC's in ground-water samples were determined by gas chromatography-mass spectrometry according to U.S. Environmental Protection Agency method 524.2 (U.S.

Environmental Protection Agency, 1991, 1992, and 1994). Compounds measured and their respective reporting limits are listed in appendix 2. All VOC analyses were performed by two laboratories certified by the New Jersey Department of Environmental Protection: Quanterra-East of Somerset, New Jersey, and Analab Inc., of Edison, New Jersey. All other analyses were performed by Quanterra-East.

\section{HYDROGEOLOGY}

\section{Geologic Setting}

The study area is within the Piedmont Physiographic Province. In New Jersey, this province coincides with the Newark Basin, which is the largest of a series of fault-block basins that extend from Nova Scotia to South Carolina (Froelich and Olsen, 1985). The basins were formed during initial continental rifting during the Triassic Period (Van Houten, 1969). The Newark Basin consists of Triassicand Jurassic-age red shales, siltstones, mudstones, sandstones, argillites, and intrusive and extrusive igneous rock. The Passaic Formation, which is part of the Newark Supergroup (Olsen, 1980 ), forms the bedrock in the study area.

\section{Hydrogeologic Framework}

In the study area, the Passaic Formation consists of interbedded layers of reddish-brown mudstone and siltstone with a few thin zones of reddish-brown shale and sandstone. Two zones of fine-grained purple siltstone about $10 \mathrm{ft}$ thick also are present. The uppermost of these purple beds was observed in rock cores and cuttings from 10 boreholes throughout the study area. The orientation of the plane formed by the top of this bed in the 10 boreholes indicates that bedding consistently strikes $\mathrm{N} .57^{\circ} \mathrm{E}$. and dips $11^{\circ}$ to the northwest throughout the study area. This bedrock orientation is consistent with the findings of dePaul (1996), which are based on measurements at outcrops. The pervasiveness of the purple marker bed in the study area also indicates that each rock stratum probably is continuous throughout the study area.

The Passaic Formation is a gently dipping, multiunit leaky aquifer system that consists of thin water-bearing units and thick intervening confining units, all of which are parallel to bedding. The rock has little primary porosity or permeability as a result of compaction and cementation; therefore, the principal means of ground-water movement is through a network of interconnected fractures.

Rock fractures in the study area are either parallel or perpendicular to bedding. Fractures perpendicular to bedding are near-vertical. Most of these near-vertical fractures are either parallel to the strike of bedding or perpendicular to it. On the basis of observations of 29 nearvertical fractures in outcrops in and near the study area, these two vertical sets contain a similar number of fractures. A few vertical fractures oriented in other directions also are present (dePaul, 1996). Fractures parallel to bedding are more continuous and extensive than vertical fractures (Michalski, 1990). Many 
vertical fractures terminate at contacts between rock types (Houghton, 1990).

Two types of water-bearing units are present in the Passaic Formation. One type is formed by major fractures parallel to bedding. The other type consists of thin geologic strata that are intensely fractured both parallel and perpendicular to bedding. All water-bearing units are bounded by confining units that are only sparsely fractured. Widely spaced vertical fractures through confining units allow water to leak from one water-bearing unit to another (Michalski, 1990).

Rocks near land surface are weathered. Clay and silt from the weathering process have partly filled the fractures in these rocks and reduced their permeability. Consequently, the framework of dipping water-bearing units and confining units is draped by a shallow weathered zone that is less permeable than deeper water-bearing units. Hydraulic-conductivity data from three sites in the Newark Basin indicate that the transition from the weathered zone to the unweathered zone occurs at a depth of about 50 to $60 \mathrm{ft}$ (Michalski, 1990). For purposes of this study, the base of the weathered zone was assumed to be at $50 \mathrm{ft}$ below land surface.

The upper part of the aquifer system is unconfined because the well-connected fractures in this material are open to the atmosphere and contain water under atmospheric pressure. At increasing depth, fractures are increasingly isolated from the atmosphere by confining units. Below a certain depth, which varies from about 50 to about $150 \mathrm{ft}$, the aquifer system is semiconfined (Houghton, 1990). For purposes of this study, the base of the unconfined zone was assumed to be at the same position as the base of the weathered zone-- $50 \mathrm{ft}$ below land surface.

At least 23 fracture zones are present in the strata penetrated by boreholes and coreholes in the study area. These zones were identified on the basis of observations of rock cores and borehole video logs and interpretations of geophysical logs. Transmissivity data from wells completed in these boreholes, however, indicate that only four of these fracture zones are capable of transmitting significant volumes of water. The interpreted position of these four water-bearing units in a section through the study area along the dip of bedding is shown in figure 3. The open intervals of all wells in which transmissivity was measured are projected onto this section. Mean transmissivity is shown for wells in which transmissivity was measured more than once. Confining units were delineated on the section by connecting the open intervals of wells in which the measured transmissivity is relatively low (less than $11 \mathrm{ft}^{2} / \mathrm{d}$ ). Water-bearing units were delineated likewise by connecting the open intervals of wells in which the measured transmissivity is relatively high (greater than $43 \mathrm{ft}^{2} / \mathrm{d}$ ). The lines delineating the units are drawn along the dip of the bedding-- $11^{\circ}$. During this process, waterbearing units and confining units were assumed to be continuous throughout the study area. In addition, it was recognized that a water-bearing unit probably intersects only part of the open interval of a well where high transmissivity was measured, whereas a confining unit probably spans the entire open interval of a well where low transmissivity was measured. Consequently, the lines separating water-bearing units from confining units are not necessarily coincident with the tops and bottoms of open intervals of wells. The transmissivity data used in this analysis are discussed in detail later in the report.

Two anomalies are present in the section (fig. 3). The transmissivity measured in well $\mathrm{CH}-2 \mathrm{MWA}$ is relatively high although this well appears to be open to the same strata as four wells (MW-2A, MW-3A, MW1A, and MW1B) in which the measured or estimated transmissivity was less than $11 \mathrm{ft}^{2} / \mathrm{d}$. The anomalously high transmissivity in the immediate vicinity 


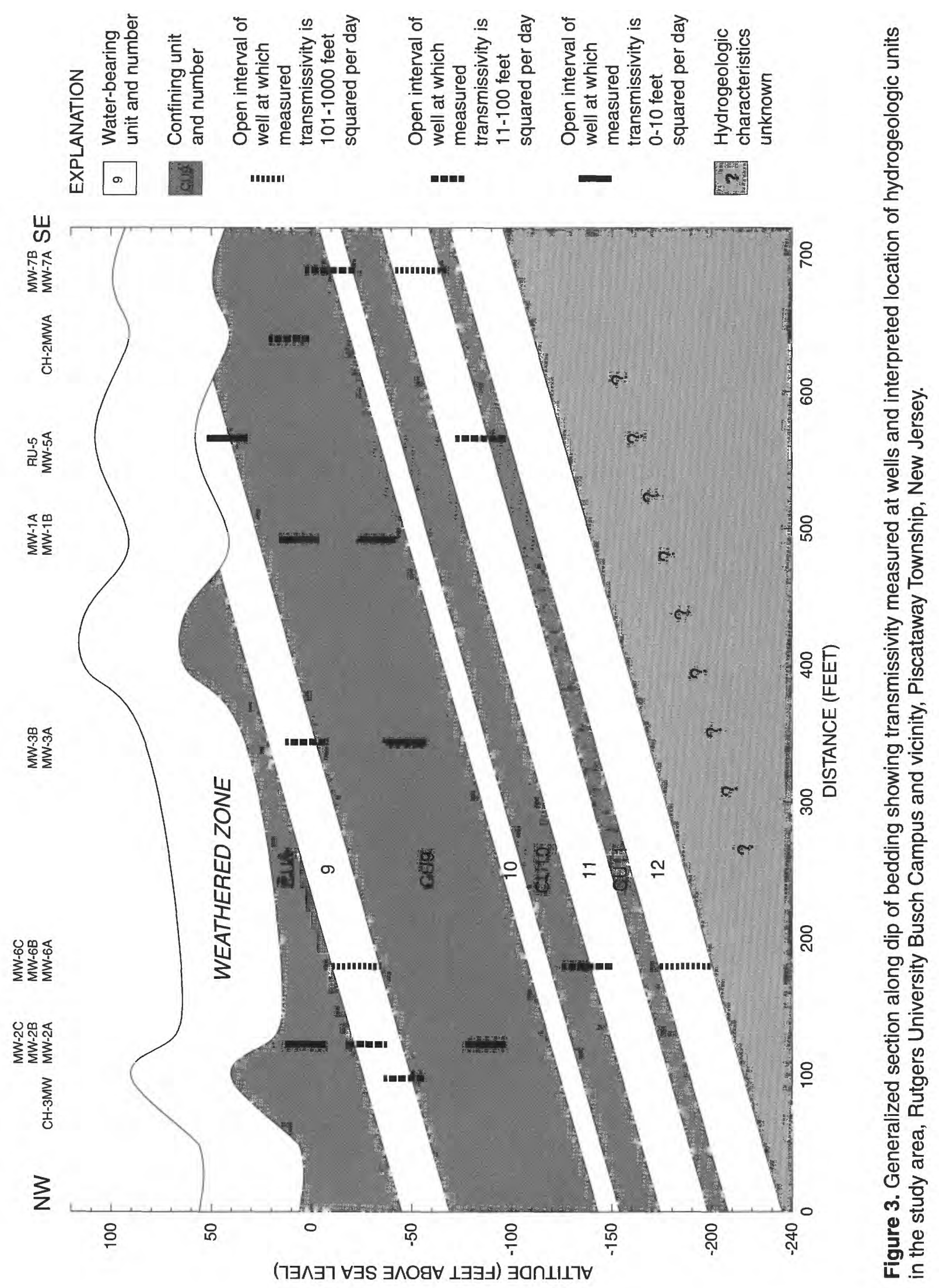


of well CH-2MWA probably is caused by a vertical fracture. A vertical fracture is present in cores from the adjacent corehole at the same depth as that of the screen in well CH-2MWA. The vertical fracture probably is one of the widely spaced fractures that are present in confining units.

The other anomaly is at well RU-5, where the measured transmissivity is relatively low-$2 \mathrm{ft}^{2} / \mathrm{d}$--although the transmissivity at four other wells in the same stratum (CH-3MW, MW2B, MW6C, and MW3B) is greater than $40 \mathrm{ft}^{2} / \mathrm{d}$. The reason for this anomaly is unknown.

Data from drilling and geophysical logs indicate that the four water-bearing units in the study area are relatively coarse-grained. Zones where loss or gain of water was significant in boreholes during drilling and zones where drilling rods were observed to drop quickly during drilling are coarse-grained siltstone and, in some cases, sandstone. Low natural-gammaradiation counts measured in these zones also indicate that these water-bearing units are relatively coarse-grained. On the basis of these findings, it is assumed that the four water-bearing units identified in the study area comprise sandstone and coarse-grained siltstone strata whereas the confining units comprise finegrained siltstone and mudstone. In the waterbearing units, fractures oriented both parallel and perpendicular to bedding are observed in rock cores and borehole video logs. Whether one or both types of fractures actually transmit water in these water-bearing units is unknown.

\section{Estimates of Hydraulic Properties}

The hydraulic properties of the rocks in the study area were estimated for use in determining the location and thickness of hydrogeologic units (described earlier) and in developing the ground-water flow model. Horizontal hydraulic conductivity and transmissivity, which are measures of the ability of a permeable medium to transmit water in the horizontal direction, were determined at wells in the study area by slug testing. The methods of Bouwer and Rice (1976) and Hvorslev (1951) were used to analyze data from slug tests conducted in wells open to the unconfined weathered zone. The method of Cooper and others (1967) was used to analyze data from slug tests conducted in the deeper wells considered to be open to confined parts of the aquifer system.

At the time of testing, the water level in some wells was recovering or being drawn down in response to recent pumping at the irrigation well. If interference was minimal, data from these tests were adjusted to remove the effects of this pumping. Otherwise, the test was repeated at a later time.

The methods used to analyze slug-test data from wells in the unconfined zone provide an estimate of horizontal hydraulic conductivity of the tested aquifer, whereas the method used to analyze slug-test data from wells in the confined zone provides an estimate of transmissivity of the tested aquifer. The transmissivity of an aquifer is equal to its horizontal hydraulic conductivity multiplied by its saturated thickness. Hydraulic conductivity in the unconfined zone ranges from 0 to $1.2 \mathrm{ft} / \mathrm{d}$, with a median of $0.12 \mathrm{ft} / \mathrm{d}$. If this zone is assumed to be $40 \mathrm{ft}$ thick (the distance from the water table, which is approximately $10 \mathrm{ft}$ below land surface, to the base of the unconfined zone at $50 \mathrm{ft}$ below land surface), then the median transmissivity of this zone is $4.8 \mathrm{ft}^{2} / \mathrm{d}$. The median transmissivity measured in wells in the confined water-bearing and confining units, respectively, is 84 and $3.7 \mathrm{ft}^{2} / \mathrm{d}$. Detailed results of slug testing are listed in table 3 and summarized in table 4. 
Table 3. Transmissivity and horizontal hydraulic conductivity at selected wells, Rutgers University Busch Campus and vicinity, Piscataway Township, New Jersey

$[\mathrm{CU}$, the confining unit below the indicated layer; W, weathered zone; NA, not applicable; C, Cooper and others, 1967; E, estimate based on extremely low recovery after insertion or removal of slug; B, Bouwer and Rice, 1976; H, Hvorslev, 1951. Well locations shown in fig. 2]

\begin{tabular}{|c|c|c|c|c|c|c|}
\hline $\begin{array}{l}\text { Local well } \\
\text { name }\end{array}$ & $\begin{array}{l}\text { Layer } \\
\text { number }\end{array}$ & $\begin{array}{l}\text { Depth of } \\
\text { screened } \\
\text { or open } \\
\text { Interval } \\
\text { (feet below } \\
\text { land } \\
\text { surface) }\end{array}$ & $\begin{array}{l}\text { Date of } \\
\text { test }\end{array}$ & $\begin{array}{l}\text { Transmissivity } \\
\text { (feet squared } \\
\text { per day) }\end{array}$ & $\begin{array}{l}\text { Hydraulic } \\
\text { conductivity } \\
\text { (feet per day) }\end{array}$ & $\begin{array}{l}\text { Analytical } \\
\text { method }\end{array}$ \\
\hline CH1-MW & W & $30-40$ & 09-08-94 & NA & 0 & $\mathbf{E}$ \\
\hline CH-2MWA & CU9 & $70-90$ & $\begin{array}{l}09-01-94 \\
11-20-96\end{array}$ & $\begin{array}{l}140 \\
54\end{array}$ & NA & $\mathrm{C}$ \\
\hline CH-2MWB & W & $30-40$ & $08-30-94$ & NA & .065 & $\mathrm{~B}, \mathrm{H}$ \\
\hline CH-3MW & 9 & $140-160$ & $08-31-94$ & 94 & NA & C \\
\hline MW-1A & CU9 & $80-100$ & $08-24-94$ & 1.4 & NA & C \\
\hline now & 140 & $1 \% 0,10$ & $08 \% 404$ & 10 & Wh & \% \\
\hline moro & 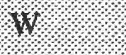 & 30,40 & $060 \% 29 \%$ & Ka & 6\% & \%1\% \\
\hline $61 \%$ & 6190 & 160,170 & $08 \% 3 \%$ & 10. & Wh & \% \\
\hline $14 W$ & 90 & 90,110 & 108\% & $110 \%$ & No & \% \\
\hline woro & 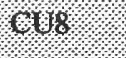 & $60 \% 80$ & 60.4096 & 60 & Wh & \% \\
\hline MW-3A & CU9 & $120-140$ & 09-01-94 & 10 & NA & C \\
\hline MW-3B & 9 & $70-90$ & 09-01-94 & 44 & NA & $\mathrm{C}$ \\
\hline MW-5A & 11 & $178-204$ & $11-19-96$ & 70 & NA & $\mathrm{C}$ \\
\hline MW-6A & 12 & $239-265$ & $11-20-96$ & 910 & NA & $\mathrm{C}$ \\
\hline MW-6B & 11 & $190-215$ & $11-18-96$ & 58 & NA & $\mathrm{C}$ \\
\hline $1106 \%$ & \% & 16100 & $118.6 \%$ & 10 & Wx & \% \\
\hline $10 \%$ & w & W10 136 & 110,96 & 180 & NK & \% \\
\hline $140 \%$ & \% & 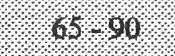 & W\% 196 & 10 & WX & \% \\
\hline no & W & 17 & 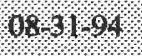 & 14 & x. & ow \\
\hline Ro & W & 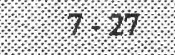 & $00.08 \%$ & na & 14 & 18\% \\
\hline RU-5 & 9 & $55-75$ & $09-08-94$ & 2.0 & NA & C \\
\hline
\end{tabular}


The transmissivity contrasts and the dipping hydrogeologic units of the aquifer system cause large-scale anisotropic flow. The predominant direction of ground-water flow through the aquifer system is the direction of strike of the bedding units, although minor variations from that direction attributable to topography, flow boundaries, and pumping are possible (Michalski, 1990). Because of this anisotropy, no attempt was made to derive flow directions from hydraulic-head gradients.

Vertical head gradients are useful in delineating ground-water recharge and discharge areas. Water-level altitudes measured on October 28,1996 , were used for this purpose because they include data from all wells on the campus and golf course. During the 8-day period preceding the measurements, only 0.08 inch of rain was recorded in the vicinity of the study area, and the irrigation well had not been pumped for at least 3 days. Water-level data indicate that these time lapses allow water levels to return to static conditions after being stressed by precipitation or by pumping the irrigation well. The irrigation well is the only well that affects water levels in wells on the campus and golf course. Therefore, these water levels represent steady-state, nonpumping conditions.

A downward vertical gradient (decreasing head with depth) was observed at well clusters at relatively high altitudes in the study area-clusters MW-1, MW-2, MW-3, CH-2, and the cluster composed of wells RU-4, RU-5, and MW-5A (fig. 2). An upward vertical gradient was observed, however, at the MW6 and MW7 well clusters, which are at lower altitudes and closer to the Raritan River than the other clusters. Water in both Rutgers golf 13 obs and the irrigation well flows under artesian pressure when water levels are high. Water levels as high as 3.0 and $17.6 \mathrm{ft}$ above land surface, respectively, have been observed at these wells. These wells are the closest to the Raritan River. The upward gradients and flowing wells near the Raritan River are indicative of an area of ground-water discharge. Therefore, the transition from a recharge area to a discharge area apparently occurs somewhere between well clusters MW2 and MW6.

Drawdowns in water levels resulting from pumping are useful in determining the effectiveness of confining units in this multiunit aquifer system. To obtain drawdown data, the pump in the irrigation well was turned on after water levels were measured on October 28, 1996. After the well was pumped continuously for 19 hours and 11 minutes, water levels were measured again. Water levels continued to decline after these measurements were made. Therefore, this data set represents transient conditions.

In the weathered zone, drawdown was greatest $(1.96 \mathrm{ft})$ in well MW1C; drawdown in 8 of the 10 wells in the weathered zone was less than $0.5 \mathrm{ft}$. Drawdown in the confined waterbearing units was much greater. Drawdown in water-bearing unit 9 ranged from a minimum of $6.81 \mathrm{ft}$ in well RU-5 to a maximum of $18.98 \mathrm{ft}$ in well MW-6C, and in water-bearing unit 11 ranged from a minimum of $13.08 \mathrm{ft}$ in well MW-7A to a maximum of $29.52 \mathrm{ft}$ in well MW-6B.

The relatively minor drawdown in the weathered zone compared to drawdown in the confined water-bearing units indicates a lack of hydraulic connection between the weathered zone and the confined water-bearing units. The irrigation well is cased through the weathered zone and open to water-bearing units 9 through 12. Another reason for the relatively minor drawdown in the weathered zone may be that the sediments that fill the fractures in the weathered zone increase ground-water storage.

The wide range in drawdown in the confined water-bearing units is caused partly by the difference in the distance of the wells from the irrigation well. The unit to which the well is open appears to be a more important factor, however. For example, drawdown in wells 
Table 4. Transmissivity in the weathered zone, waterbearing units, and confining units, Rutgers University Busch Campus and vicinity Piscataway Township, New Jersey

$\left[\mathrm{ft}^{2} / \mathrm{d}\right.$, feet squared per day]

\begin{tabular}{lcc}
\hline & $\begin{array}{c}\text { Median } \\
\left(\mathrm{ft}^{2} / \mathrm{d}\right)\end{array}$ & $\begin{array}{l}\text { Range } \\
\left(\mathrm{ft}^{2} / \mathrm{d}\right)\end{array}$ \\
\hline Weathered zone & 4.8 & $0-48$ \\
Water-bearing units & 84 & $2-910$ \\
Confining units & 3.7 & $0-97$ \\
\hline
\end{tabular}

The vertical hydraulic conductivity of rocks similar to those in the study area was estimated at four locations in previous studies by model calibration. The vertical conductivity of the Passaic Formation at a site in northern Mercer County, New Jersey, is on the order of $0.0001 \mathrm{ft} / \mathrm{d}$ (Carleton and others, 1999). In parts of Mercer, Somerset, and Hunterdon Counties, New Jersey, the vertical conductivity of the Passaic Formation is about $32 \mathrm{ft} / \mathrm{d}$ in rocks less than $75 \mathrm{ft}$ below land surface and $0.032 \mathrm{ft} / \mathrm{d}$ in rocks at depths between 75 and $500 \mathrm{ft}$ below land surface (Lewis-Brown and Jacobsen, 1995). Gerhart and Lazorchick (1988) report vertical conductivities ranging from 0.13 to $3.34 \mathrm{ft} / \mathrm{d}$ in fractured sedimentary rocks in the Gettysburg Triassic rift basin in Pennsylvania and Maryland. Chichester (1996) reports a range of 0.1 to $0.6 \mathrm{ft} / \mathrm{d}$ in the vertical conductivity of rocks in the Cumberland Valley of Pennsylvania, which includes parts of the Gettysburg Triassic rift basin. The overall range in vertical hydraulic conductivity at these locations is 0.0001 to $32 \mathrm{ft} / \mathrm{d}$.

Estimates of vertical hydraulic conductivity made on the basis of calibration of digital models of ground-water flow rely on the premise that the values of other parameters in the model are much better known because they are based on field measurements. The value of vertical hydraulic conductivity is then solved for by adjusting this value until the simulated ground-water system closely matches the real system. The ground-water system in most of these models, however, was reported to be relatively insensitive to the value of vertical hydraulic conductivity. Consequently, the wide range of reported values is not unexpected.

\section{GROUND-WATER FLOW}

Ground-water flow in the study area is controlled primarily by the distribution of waterbearing fractures in the dipping strata that make up the hydrogeologic framework and by contrasts in transmissivity within the aquifer system. Both a conceptual and a digital model were used to analyze the flow system in the study area and its effect on the distribution of contaminants.

\section{Conceptual Model}

Recharge to the ground-water system is by downward leakage of precipitation. After passing vertically through the unsaturated zone, water reaches the top of the weathered zone. Because the weathered zone is much less permeable than the underlying water-bearing units, water probably flows only a few hundred feet laterally before reaching the bottom of the weathered zone and flowing into one of the underlying confined water-bearing units.

Water that reaches one of the confined water-bearing units water typically flows in that unit for some distance before reaching the contact between the water-bearing unit and a confining unit. The water then typically passes through a vertical fracture in the confining unit and into the next water-bearing unit. Flow through confining units generally is vertical as a result of head differences between the waterbearing units. Ground water discharges primarily to the Raritan River and its tributaries.

Smaller amounts of water discharge to the irrigation well and 11 domestic wells in the study area. 
MW-6A, MW-6B, and MW-6C, all of which are equidistant from the irrigation well, was $63.68,29.52$, and $18.98 \mathrm{ft}$, respectively. These wells are open to water-bearing units 12,11 , and 9 , respectively (fig. 3 ). The irrigation well is open to all of these units. The large differences in drawdown among these wells probably result from effective separation of these units from one another by the intervening confining units.

Water levels and drawdowns in wells on October 28 and 29, 1996, are shown in table 6 (farther on). All water-level data for wells in the study area are presented in appendix 1 .

\section{Simulated Ground-Water Flow System}

A digital model of the ground-water flow system was developed for three purposes: (1) to test hypotheses developed in the conceptual model concerning the movement of ground water, (2) to help guide the placement of new monitor wells, and (3) to estimate potential paths of contaminated water from the vicinity of the C-Wing building. The model was used to simulate both steady-state and transient flow conditions, although the transient simulation was used only for calibration.

\section{Description of digital model}

A three-dimensional, finite-difference Fortran code (MODFLOW) developed by McDonald and Harbaugh (1988) was used. No modifications were made to the published code.

\section{Model area and grid}

The model area was extended beyond the study area to include natural hydrologic boundaries. It encompasses $2.3 \mathrm{mi}^{2}$, including McEttis Brook near its northwestern boundary and the Raritan River at its southwestern boundary (fig. 4). The model grid was oriented so that the columns are parallel to the strike of the rock layers. The model was discretized horizontally into 100 rows and 63 columns. Model cells are smallest in the part of the model that represents the study area, where each cell is $49 \mathrm{ft}$ long and $49 \mathrm{ft}$ wide. At the edges of the model, cells are $217 \mathrm{ft}$ long and $217 \mathrm{ft}$ wide.

The model is discretized vertically into 20 layers. Throughout the model area, layer 1 represents the $40-\mathrm{ft}$-thick unconfined weathered zone just below the water table. The other 19 model layers represent dipping water-bearing units. Confining units are represented by low rates of vertical leakance between water-bearing units, as described by McDonald and Harbaugh (1988).

Model layers 9-12 represent the four water-bearing units identified in the study area. Because the geologic strata dip to the northnorthwest, these four units are increasingly deep in parts of the model area north-northwest of the study area and increasingly shallow south-southeast of the study area. Water-bearing units similar to these four units are assumed to be present stratigraphically above and below them in the northwestern and southeastern parts of the model area, respectively. Layers 2-8 and 13-20 represent these hypothetical water-bearing units that are stratigraphically above and below layers 9-12. These additional layers are assumed to have the same strike, dip, and hydraulic properties as those in the study area. Each hypothetical unit was assigned a thickness approximately twice the average thickness of the units in the study area to minimize the number of hypothetical units needed to fully represent the model area and, in turn, reduce computation time during model calibration. This assumed hydrogeologic framework in the model area is shown in sections B-B' (parallel to strike) and C-C' (parallel to dip) in figures 5 and 6, respectively.

Representation of water-bearing units as model layers is complicated by the fact that the units dip. The model code requires that each model layer be represented in some way over the full extent of the model area even though 


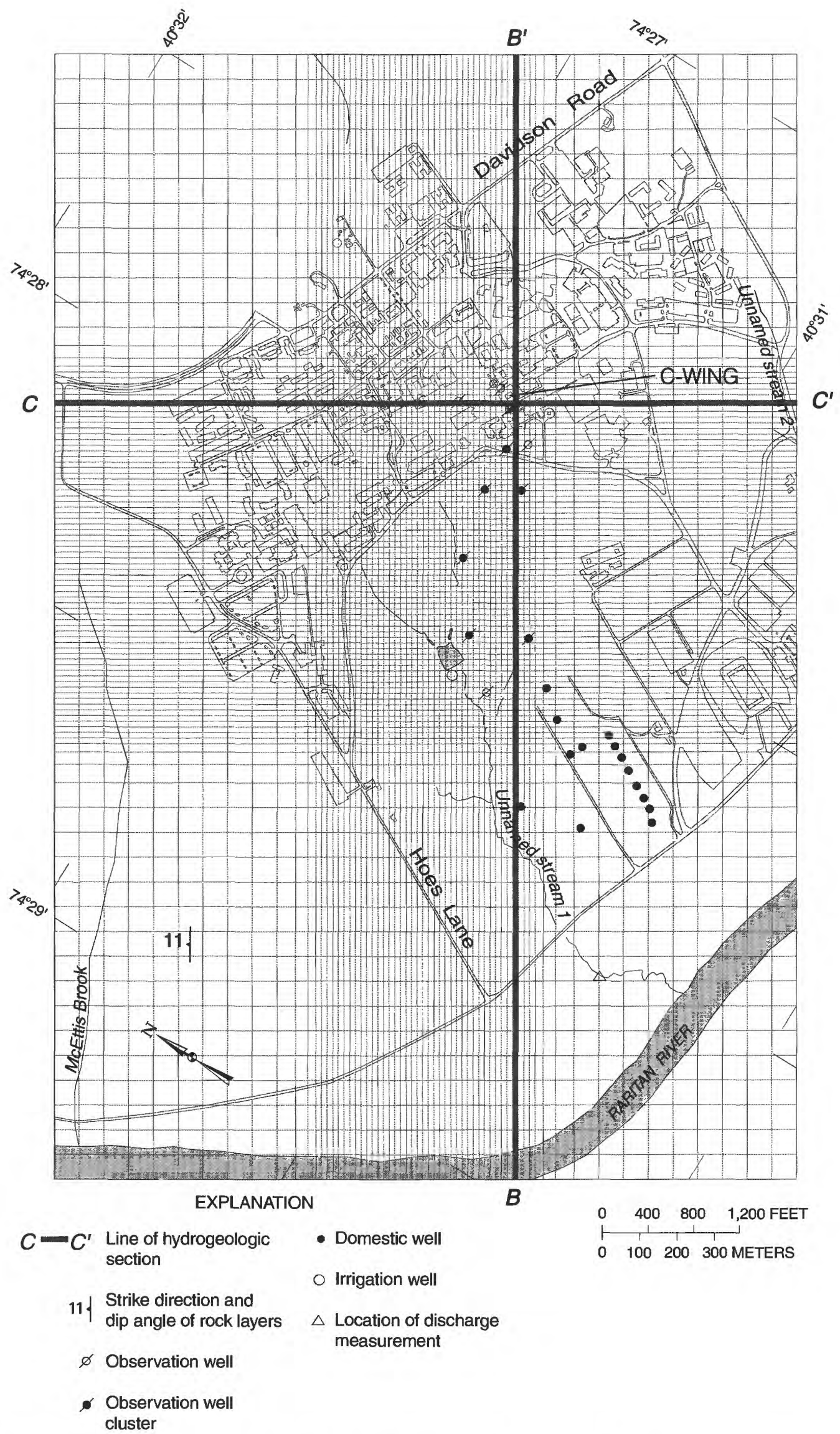

Figure 4. Area of ground-water flow model showing horizontal discretization and lines of hydrogeologic sections, Rutgers University Busch Campus and vicinity, Piscataway Township, New Jersey. 


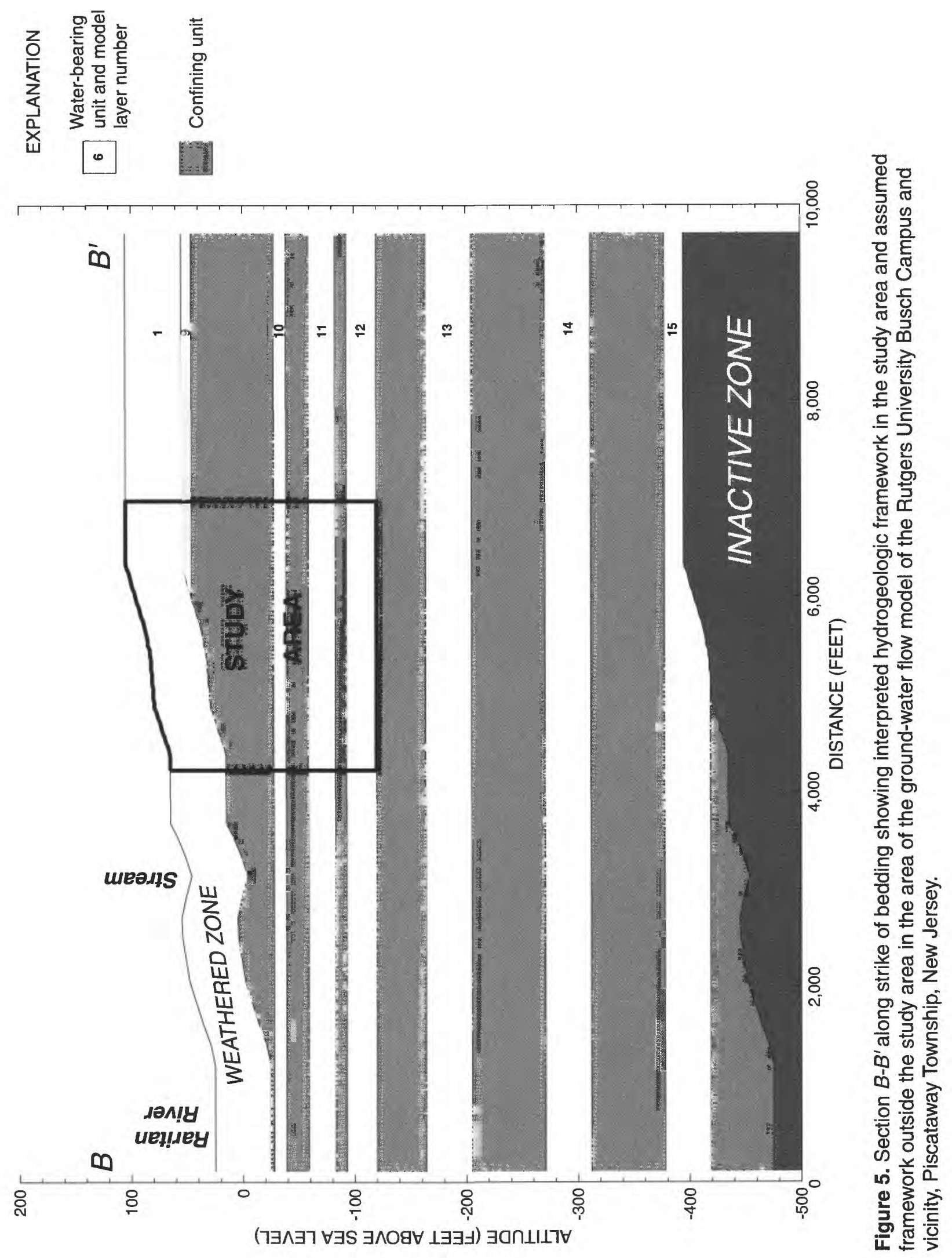



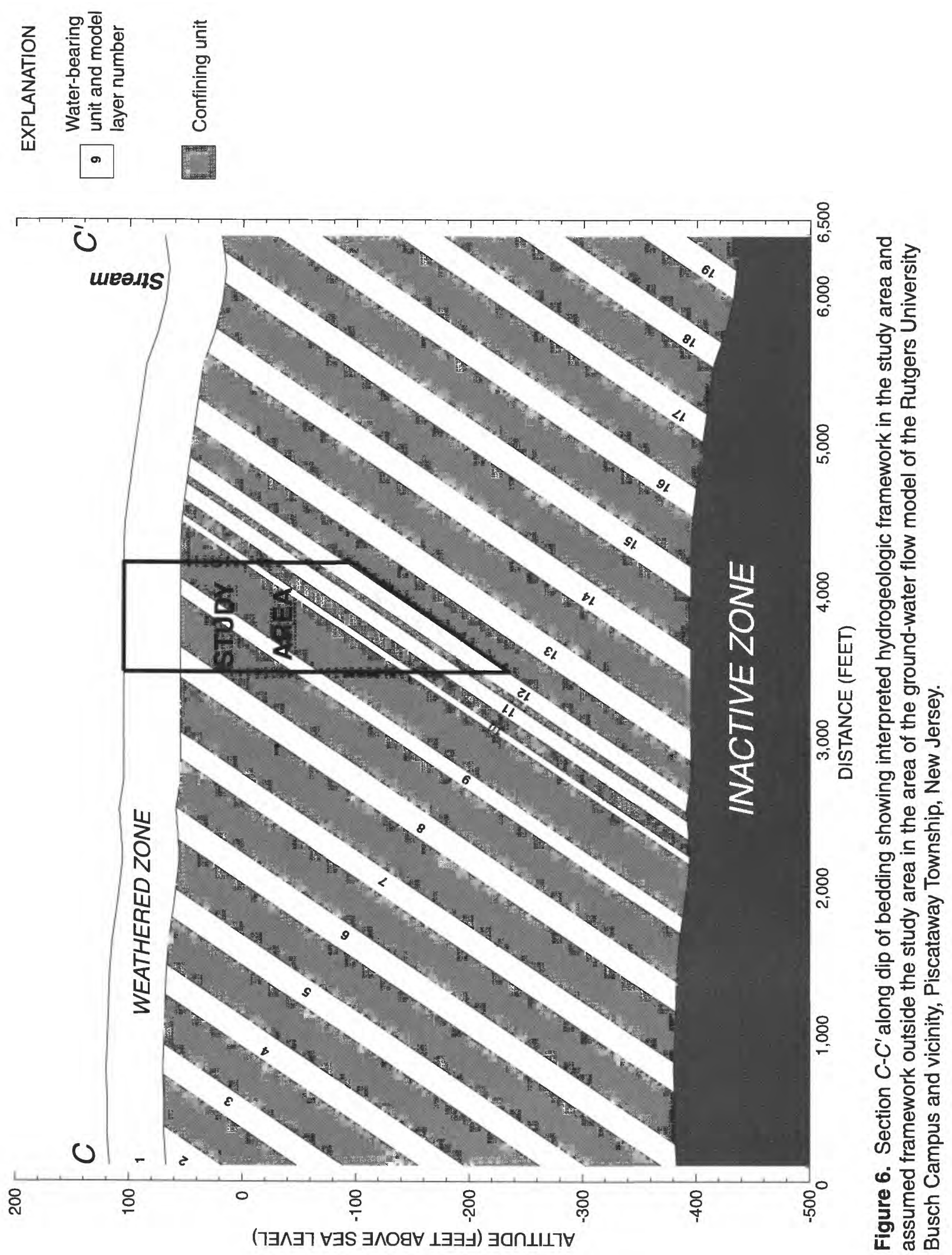
the actual water-bearing units are not present over the full area. Each water-bearing unit terminates updip at the base of the weathered zone. Although each water-bearing unit probably extends thousands of $\mathrm{ft}$ downdip, groundwater flow is assumed to be negligible at depths greater than $500 \mathrm{ft}$ below land surface, as explained in the section on model boundaries (below). In order to represent these changes in the character of each water-bearing unit, each model layer is made up of three segments. These segments are illustrated for hydrogeologic section C- C', as represented in the model, in figure 7 . The most downdip of these segments is an inactive zone and represents the part of the water-bearing unit that is deeper than $500 \mathrm{ft}$ below land surface. The next segment is the active zone, representing the part of the water-bearing unit between the weathered zone and $500 \mathrm{ft}$. The next segment is pseudoactive and represents the imaginary extension of the water-bearing unit updip from its outcrop. Although this part of a model layer represents imaginary sediments above the weathered zone, the entire model layer is positioned below the weathered zone. Therefore, the pseudoactive segment is modeled as active in order to allow water to flow from the weathered zone, through the pseudo-active zone, to the first water-bearing unit that is actually beneath the weathered zone.

\section{Model boundaries}

The upper boundary of the model represents the water table and is the top of model layer 1, the weathered zone. A specified flux is applied to the top of this uppermost layer to represent areal recharge from precipitation. The northwestern and southeastern edges of the model area are bounded by no-flow cells. Because these boundaries are parallel to the strike of the rock layers, and ground water flows parallel or subparallel to the strike direction, it is assumed that these boundaries are parallel to flow lines and that a negligible amount of water crosses them.
The southwestern limit of the active model area coincides with the Raritan River. This boundary was simulated as a head-dependent flux boundary. In cells beneath the river, it was assumed that ground-water flow is vertically upward toward the river and that no horizontal flow occurs beneath the river. Model cells southwest of the river are inactive (no-flow boundaries).

The northeastern boundary of the model initially was placed at a surface-water drainage divide near the northeastern border of the study area. During model calibration, however, it became evident that some ground water probably crosses that boundary from the northeast, but a flow rate could not be determined. Therefore, a no-flow boundary was placed throughout row 1 of the model, which is $2,800 \mathrm{ft}$ northeast of the study area. Although some flow probably crosses this boundary, it is assumed that any such flow is sufficiently far from the study area that its effect on simulated flow in the study area is minimal.

The bottom of the active model is $500 \mathrm{ft}$ below land surface throughout the modeled area. All model cells that represent parts of water-bearing units deeper than $500 \mathrm{ft}$ are inactive. This depth was chosen for two reasons: (1) The deepest well in the study area is $300 \mathrm{ft}$ deep; therefore, no field data for depths greater than $300 \mathrm{ft}$ are available. (2) It is assumed that any flow that may occur below $500 \mathrm{ft}$ is separated by confining units from flow occurring in the 0-to-300-ft-depth zone and, therefore, ground-water flow and contaminant transport in the study area are not affected by any flow that may occur at depths greater than $500 \mathrm{ft}$.

\section{Assumptions, limitations, and appropriate uses of the model}

Ground-water flow in fractured rocks is too complex to be succinctly simulated with a digital model. If several necessary but simplifying assumptions are made, however, a model can be constructed that is capable of approximating flow through the fractured framework. 


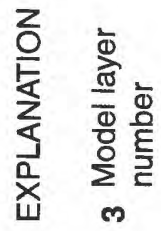

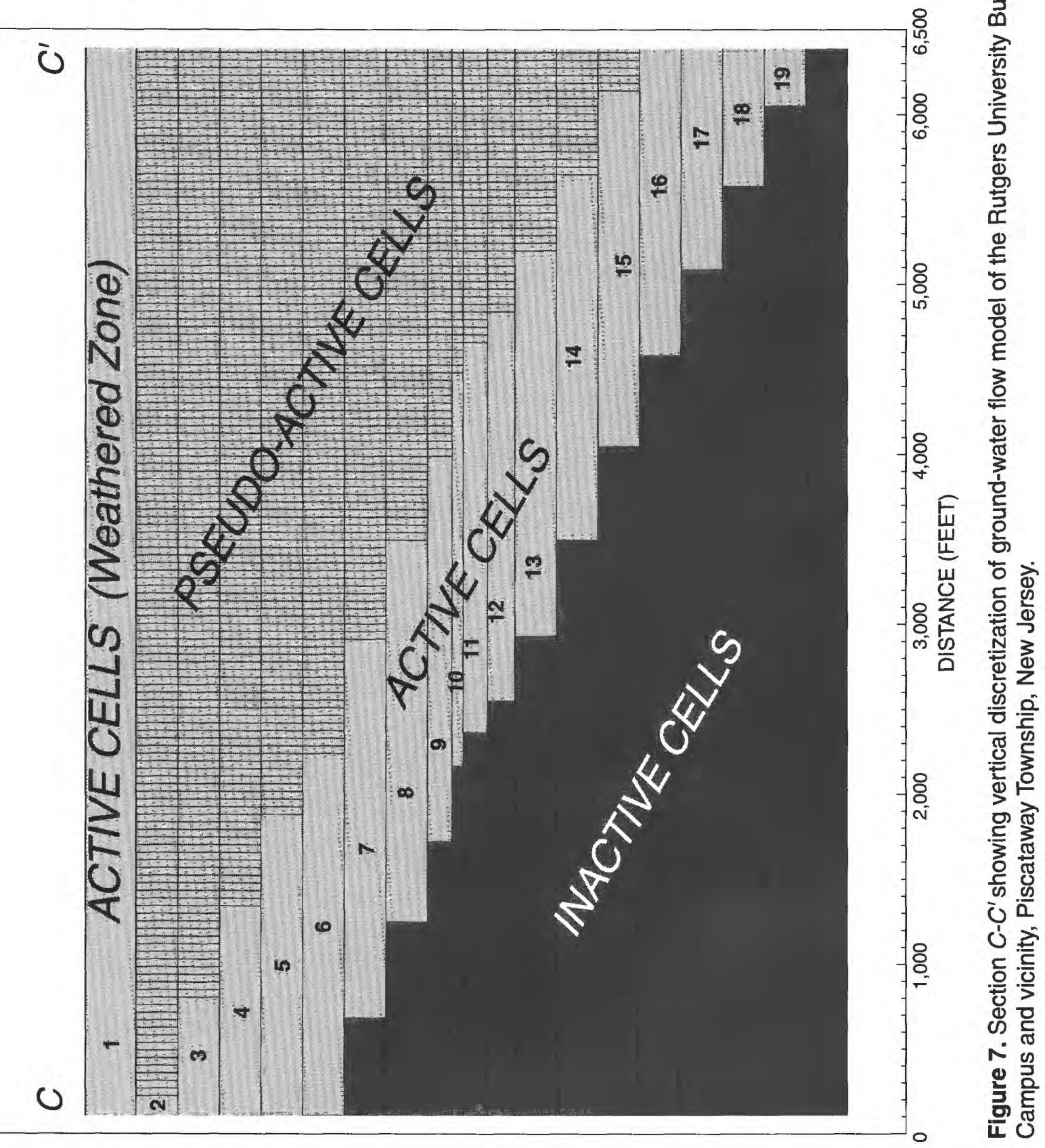


The model structure is based on a simplified conceptualization of the ground-water flow system. The fractured rocks are modeled as equivalent porous media. Thus, we assume that ground-water flow can be described by using a standard three-dimensional flow equation based on Darcy's Law. In this approach, the hydraulic-conductivity and storativity values used in the model represent the bulk properties of the fractured rock represented by each model layer. Water flux, which in reality may occur in only a small fraction of the layer that is occupied by fractures, is simulated as being distributed throughout each layer. This assumption means that the model cannot be used to simulate local or small-scale ground-water flow paths that are controlled by a few discrete fractures. Each model cell represents a volume of aquifer material that contains many fractures. The model calculates the flow path from one cell to the next by simulating the net effect of all of the fractures in that interval. Therefore, the model cannot be used to simulate paths on a scale smaller than the cell size. In the study area, this means that paths on a scale that is smaller than a $49-\mathrm{ft}$ by 49-ft square cannot be simulated.

The primary intended use of this model is simulation of ground-water flow and advective contaminant transport in the study area. Most of the data used to calibrate the model are from the study area. Therefore, use of the model to obtain detailed predictions of ground-water conditions outside the study area would be inappropriate.

The digital model used in this study simulates only the advective flow of ground water. Dilution and dispersion of dissolved contaminants, movement of dense non-aqueous phase liquids due to gravity effects, and mixing of variable-density fluids are not simulated in the model. The model can be used to estimate flowpaths; however, it cannot appropriately be used alone to identify or rule out suspected sources of contamination.
The model can be used to estimate the effects of stresses such as ground-water pumping, drought, or artificial recharge on the flow system. If the effects of simulated pumping extend beyond the model boundaries, however, drawdown within the model area will be overestimated.

The model was calibrated by using water levels measured in October 1996. Although water levels generally are low in early fall, 1996 was an unusually wet year. Precipitation during 1996 was the second highest of that in all years during 1968-97. Consequently, the water levels used to calibrate the model probably were somewhat higher than mean water levels under static conditions. Ideally, a steadystate model is calibrated to average conditions, when the amount of water entering the groundwater system equals the amount leaving it. Under wet conditions, more water is entering the system than leaving it.

The use of wet-condition water levels to calibrate the model probably has little effect on the simulated flow paths. The relatively high water levels probably caused the hydraulichead gradient to be steeper than average, however, especially in the weathered zone. A steep gradient would cause more water to flow through the system at higher velocities than average, but flow paths would not be different.

The hydraulic parameters determined by model calibration probably are different than they would have been if average water levels had been used during calibration. Recharge and storativity may be overestimated, and the horizontal hydraulic conductivity, vertical hydraulic conductivity, and streambed conductivity may be underestimated in the model. These potential overestimates and underestimates need to be considered if these parameters are used in other applications. 
Model Calibration

During calibration of the digital model, values of hydraulic parameters were varied within reasonable ranges until acceptable matches were achieved between measured and simulated static ground-water levels, drawdown, and base flow to unnamed stream 1 .

\section{Hydraulic parameters}

The hydraulic parameters that were adjusted during calibration are areal recharge, transmissivity, vertical hydraulic leakance, streambed conductance, specific yield, and storage coefficient. Values that were relatively well known were adjusted over smaller ranges than values that were less well known. The value of each parameter used in the final calibrated model is listed in table 5 .

\section{Areal recharge}

Areal recharge was considered to be one of the better known parameter values because an estimate of recharge to the Passaic Formation was available from a previous study (LewisBrown and Jacobsen, 1995). That estimate of 8.2 inches per year was derived from measurements of base flow, ground-water pumpage, and sewage inflows to streams in west-central New Jersey and was used as the starting value of recharge during calibration. Land use differs between the two areas, however. In the westcentral New Jersey study area, most land is either undeveloped or farmed, whereas the Busch Campus has been extensively developed. Many buildings, roads, and parking lots intercept precipitation at the campus, and most of the intercepted precipitation flows to storm sewers. In addition, several drains have been installed in grassy areas of the campus and golf course to prevent these areas from becoming

Table 5. Hydraulic parameters used in digital model of ground-water flow, Rutgers University Busch Campus and vicinity, Piscataway Township, New Jersey

[ft/d, feet per day; $\mathrm{ft}^{2} / \mathrm{d}$, feet squared per day]

\begin{tabular}{|c|c|c|c|}
\hline Parameter & Value & Comments & $\begin{array}{l}\text { Governing } \\
\text { equation }\end{array}$ \\
\hline Areal recharge & $0.0017 \mathrm{ft} / \mathrm{d}$ & & \\
\hline $\begin{array}{l}\text { Transmissivity } \\
\text {-Layer } 1 \text { (weathered zone) } \\
\text {-Layers } 2-8 \text { and } 13-20 \\
\text {-Layers } 9 \text { and } 12 \\
\text {-Layers } 10 \text { and } 11\end{array}$ & $\begin{array}{l}16 \mathrm{ft}^{2} / \mathrm{d} \\
110-440 \mathrm{ft}^{2} / \mathrm{d} \\
120-500 \mathrm{ft}^{2} / \mathrm{d} \\
470-1,900 \mathrm{ft}^{2} / \mathrm{d}\end{array}$ & $\begin{array}{l}\text { Decreases with depth } \\
\text { Decreases with depth } \\
\text { Decreases with depth }\end{array}$ & $\begin{array}{l}4550 / \text { depth }^{0.6} \\
5200 / \text { depth }^{0.6} \\
19,500 / \text { depth }^{0.6}\end{array}$ \\
\hline $\begin{array}{l}\text { Vertical hydraulic conductivity } \\
\text {-Layer } 1 \text { (weathered zone) }\end{array}$ & $4.0 \times 10^{-3} \mathrm{ft} / \mathrm{d}$ & & \\
\hline $\begin{array}{l}- \text { Confining units below layers } 2-8 \\
\text { and } 10-19\end{array}$ & $1.9 \times 10^{-8}-7.7 \times 10^{-5} \mathrm{ft} / \mathrm{d}$ & Decreases with depth & $10^{2} /$ depth $^{3.6}$ \\
\hline $\begin{array}{l}\text {-Confining unit below layer } 9 \\
\text {-Streambeds and riverbed }\end{array}$ & $\begin{array}{l}1.9 \times 10^{-4}-7.7 \times 10^{-1} \mathrm{ft} / \mathrm{d} \\
1.0 \mathrm{ft} / \mathrm{d}\end{array}$ & $\begin{array}{l}\text { Conductivity is high } \\
\text { because confining unit is } \\
\text { leaky }\end{array}$ & $10^{6} / \mathrm{depth}^{3.6}$ \\
\hline $\begin{array}{l}\text { Storage coefficient } \\
\text {-Layer 1 } \\
\text {-Layers 2-20 }\end{array}$ & $\begin{array}{l}3.0 \times 10^{-2} \\
4.0 \times 10^{-7}\end{array}$ & & \\
\hline
\end{tabular}


muddy. Therefore, the amount of areal recharge at the west-central New Jersey study area was considered to be the maximum reasonable value of recharge in the current study area. In the calibrated model, simulated water levels and base flow best matched the measured values when an areal recharge of 7.4 inches per year $(0.0017 \mathrm{ft} / \mathrm{d})$ was applied.

\section{Transmissivity}

Transmissivity was considered to be one of the better known parameter values in the model because estimates were available from analysis of slug-test data. The actual values of measured transmissivity were assumed to be subject to a potential error of about one order of magnitude because of uncertainty related to curve-matching and interference caused by pumping at the irrigation well.Therefore, adjustments of up to about one order of magnitude from the measured values were allowed during calibration.

In the digital model, the weathered zone was initially assigned a transmissivity of 4.8 $\mathrm{ft}^{2} / \mathrm{d}$--the mean transmissivity measured in this zone by slug testing. During model calibration, the transmissivity in this zone was adjusted to $16 \mathrm{ft}^{2} / \mathrm{d}$.

The water-bearing units represented by model layers $2-20$ were initially assigned a transmissivity of $84 \mathrm{ft}^{2} / \mathrm{d}$--the mean transmissivity measured in water-bearing units 9-12. During model calibration, it was found that simulated water levels, drawdown, and base flow better matched the measured values if the transmissivity in each of these units decreased with depth. Although the transmissivity data obtained in the study area by slug testing do not indicate any trend as a function of depth, only 10 wells are open to water-bearing units; therefore, it is not surprising that no trend is indicated in so few data. In a previous study in west-central New Jersey, however, the specific capacity per foot of open hole of 709 wells in the Passaic Formation was found to decrease with depth (Lewis-Brown and Jacobsen, 1995).
There the median specific capacity per foot of open hole in wells 76 to $100 \mathrm{ft}$ deep is 0.00771 , and the median specific capacity of deeper wells is increasingly smaller. The specific capacity per foot of open hole of the deepest wells (251-300 ft deep) is 0.00051. Specific capacity per foot of open hole is a parameter used to estimate transmissivity (Heath, 1983).

During model calibration, it was also determined that simulated conditions best match measured conditions when the transmissivity assigned to model layers 9 and 12 ranges from $120 \mathrm{ft}^{2} / \mathrm{d}$ at the greatest depths to $500 \mathrm{ft}^{2} / \mathrm{d}$ at the shallowest depths; the transmissivity assigned to model layers 10 and 11 ranges from 470 to $1,900 \mathrm{ft}^{2} / \mathrm{d}$; and the transmissivity assigned to all of the hypothetical layers ranges from 110 to $440 \mathrm{ft}^{2} / \mathrm{d}$. The depthdependent transmissivity at each model cell was calculated by using a computer program separate from the model. The equations used to determine transmissivity at each cell are listed in table 5.

During model calibration, several model runs were made with anisotropy incorporated into each water-bearing unit by varying the ratio of horizontal hydraulic conductivity in the strike direction to that in the dip direction. Ratios varying from 1:2 to 1:10 were tested. The best model calibration was achieved when no anisotropy was incorporated into individual model layers; however, the large-scale anisotropy present in the study area, wherein water flows preferentially in the strike direction, is simulated by the model. The large-scale anisotropy is a result of transmissivity contrasts in the aquifer system. Water is impeded from flowing horizontally across units in the dip direction because of the low transmissivity of the confining units (fig. 6). Likewise, water is impeded from flowing any great distance downdip within a water-bearing unit because the transmissivity of each unit decreases with depth. Consequently, water flows along the path of least resistance (greatest transmissivity), which 
is through a water-bearing unit and in the strike direction (into the page in figure 6). All of these transmissivity contrasts are represented in the model, with the result that simulated flow paths are predominantly along strike.

Pseudo-active cells were assigned a transmissivity of zero. The purpose of this zone, as described earlier, is to allow instantaneous vertical flow, but no horizontal flow, through parts of model layers that represent non-existent extensions of water-bearing units updip from their outcrops.

\section{Vertical hydraulic conductivity and vertical leakance}

All of the estimates of vertical hydraulic conductivity in rocks similar to those in the study area, which vary from 0.0001 to $32 \mathrm{ft} / \mathrm{d}$, apply to the bulk vertical conductivity of aquifer systems composed of both water-bearing and confining units. Therefore, vertical hydraulic conductivity was allowed to vary over several orders of magnitude during model calibration.

Simulated heads, drawdown, and base flow best matched measured conditions when the vertical conductivity of the weathered zone was $4.0 \times 10^{-3} \mathrm{ft} / \mathrm{d}$ and the vertical conductivity of each confining unit, like the horizontal transmissivity of the water-bearing units, decreased with depth. The best model calibration was achieved when all confining units except the one below water-bearing unit 9 were assigned vertical-conductivity values ranging from $1.9 \mathrm{x}$ $10^{-8}$ to $7.7 \times 10^{-5} \mathrm{ft} / \mathrm{d}$. The confining unit below water-bearing unit 9 was assigned vertical-conductivity values four orders of magnitude higher than those of the other confining units. This is an indication that this confining unit is leakier than the others. Values of vertical hydraulic conductivity used in the model and the equations used to calculate the depthdependent values are listed in table 5.

Vertical leakance, rather than vertical hydraulic conductivity, is the parameter actu- ally incorporated into the model. Vertical leakance is the vertical conductivity of the depth interval between the center of a model cell and the center of the model cell beneath it divided by the length of that interval. The vertical leakance applied to model cells representing the weathered zone depends on the type of unit that is below the weathered zone. In some places, a water bearing unit is directly beneath the weathered zone, and in other places a confining unit is directly beneath the weathered zone (fig. 6 ). The case in which a water-bearing unit directly underlies the weathered zone is analogous to the situation described by McDonald and Harbaugh (1988) in which two adjacent model layers are used to represent two vertically adjacent hydrogeologic units. In this case, the vertical leakance assigned to the cell representing the weathered zone is defined as

$$
\text { Vcont }=\frac{1}{\frac{m_{W}}{2 K_{z w}}+\frac{m_{w b}}{2 K_{z w b}}}
$$

where

Vcont is the vertical leakance,

$\mathrm{m}_{\mathrm{w}}$ is the thickness of the weathered zone,

$\mathrm{m}_{\mathrm{wb}}$ is the thickness of the water-bearing unit directly beneath the weathered zone,

$\mathrm{K}_{\mathrm{zW}}$ is the vertical hydraulic conductivity of the weathered zone, and

$\mathrm{K}_{\mathrm{zwb}}$ is the vertical hydraulic conductivity of the water-bearing unit directly beneath the weathered zone.

An analysis of the reasonable ranges of values of the parameters in equation 1 indicates that the vertical conductivity of the weathered zone controls the value of vertical leakance because the vertical conductivity of the weathered zone is orders of magnitude lower than that of the water-bearing units. Consequently, the terms for vertical conductivity and thickness of the water-bearing unit underlying the 
weathered zone can be disregarded, and the resulting equation is

$$
V c o n t=\frac{2 K_{z W}}{m_{w}} .
$$

The case in which a confining unit is present between the weathered zone and the underlying water-bearing unit is analogous to the situation described by McDonald and Harbaugh (1988) in which two adjacent model layers are used to represent two water-bearing units separated by an interbedded confining unit. In this case, the vertical leakance assigned to the cell representing the weathered zone is defined as

$$
\text { Vcont }=\frac{1}{\frac{m_{w}}{2 K_{z w}}+\frac{m_{c}}{K_{z c}}+\frac{m w b}{2 K_{z} w b}}
$$

where and

$m_{c}$ is the thickness of the confining unit,

$\mathrm{K}_{\mathrm{zc}}$ is the vertical hydraulic conductivity of the confining unit.

In this case, the vertical conductivity of both the weathered zone and the confining unit is much lower than that of the water-bearing unit, so the terms representing the thickness and conductivity of the water-bearing unit can be disregarded, and the resulting equation is

$$
\text { Vcont }=\frac{1}{\frac{m_{w}}{2 K_{z w}}+\frac{m_{c}}{K_{z c}}} .
$$

Model layers 2-19 each represent a waterbearing unit that is underlain by a confining unit which, in turn, is underlain by another water-bearing unit. In this situation, the vertical conductivity of the confining unit is orders of magnitude smaller than that of the water-bearing units, and the vertical leakance is defined by the equation:

$$
\text { Vcont }=\frac{K_{z_{c}}}{m_{c}} .
$$

A computer program separate from the model was used to calculate the leakance at each model cell according to equation 2,3 , or 4 . Pseudo-active cells were assigned a vertical leakance of $100 \mathrm{ft} / \mathrm{d}$ to allow near-instantaneous vertical flow through these cells.

\section{Streambed hydraulic conductance}

Streams were simulated as head-dependent flux boundaries by using the "river module" of MODFLOW. In this module, the head in the stream is specified, and water flows between the aquifer and the stream through the streambed. The rate of flow between the aquifer and the stream is controlled by the head difference between the stream and the aquifer, and the hydraulic conductance of the streambed.

McDonald and Harbaugh (1988) define this conductance according to the equation:

$$
C r i v=\frac{K_{S} L W}{m_{S}}
$$

where

$\mathrm{C}_{\text {riv }}$ is the hydraulic conductance of the stream-aquifer interconnection;

$\mathrm{K}_{\mathrm{s}}$ is the vertical hydraulic conductivity of the streambed material,

$L$ is the length of the reach,

$\mathrm{W}$ is the width of the stream, and

$\mathrm{m}_{\mathrm{s}}$ is the thickness of the streambed.

Streambed material in the study area consists of silt or fractured bedrock with silt filling the fractures. Heath (1983) estimated the horizontal hydraulic conductivity of silt to range from 0.003 to $10 \mathrm{ft} / \mathrm{d}$. In the calibrated model, simulated heads, drawdown, and base flow were nearest measured conditions when a vertical conductivity of $1 \mathrm{ft} / \mathrm{d}$ was assigned to the bed material of the Raritan River and its tributaries. 
The length of the tributaries to the Raritan River within each model cell was determined from topographic maps by means of a geographic information system. The width of these three streams was estimated to be $3 \mathrm{ft}$ on the basis of measurements at a few representative sites. Because the Raritan River is about $300 \mathrm{ft}$ wide in the model area, its area $(\mathrm{Lx} \mathrm{W})$ within each model cell was determined by digital scanning of topographic maps. The thickness of the streambed was estimated to be $5 \mathrm{ft}$ in the tributaries and $10 \mathrm{ft}$ in the Raritan River.

\section{Specific yield and storage coefficient}

Specific yield is used to define the storage capacity of model layer 1 , the weathered zone, which is assumed to be unconfined. Specific yield is defined as the ratio of the volume of water that can be drained from a rock to the volume of the rock. In the calibrated model, the specific yield of the weathered zone was set at $3.0 \times 10^{-2}$.

The storage term used in the model for confined water-bearing units below the weathered zone is storage coefficient--specific storage of the water-bearing unit multiplied by the thickness of the water-bearing unit. Specific storage is the amount of water released from or taken into storage per unit volume of aquifer material per unit change in head. Rima and others (1962) found that the storage coefficient of the upper part of the Stockton Formation in southeastern Pennsylvania is about $1.37 \times 10^{-4}$. Because the transmissivity of the Passaic Formation is lower than that of the Stockton Formation, it is assumed that the storage coefficient of the Passaic Formation is less than $10^{-4}$. As a result of model calibration, specific storage in layers $2-20$ was set at $4.0 \times 10^{-7}$.

\section{Pumpage}

In the study area, the only wells from which water is withdrawn are 11 domestic wells and the irrigation well. Pumpage at the domestic wells was estimated by assuming that each household includes four persons and that each person uses $75 \mathrm{gal}$ of water per day. The pumping rate at the domestic wells was assumed to be constant over time.

Pumpage at the irrigation well initially was distributed equally among the four model layers intersected by the well opening (layers 9 12). During calibration of the transient model, the pumpage was redistributed until the best match between measured and simulated drawdown was achieved. In the calibrated model, $18,17,22$, and 43 percent of the total pumpage is applied to layers $9,10,11$, and 12 , respectively. This distribution also was used in the steady-state simulations.

The total volume of water pumped over the 19-hour period simulated by the transient model was $40,561 \mathrm{ft}^{3}$. No records were kept of any changes in pumping rate over that period, but it is assumed that the rate decreased with time because of drawdown in the well. Therefore, in the transient model, the total pumping time is divided into five equal stress periods; the pumping rate decreases from each stress period to the next, and in the last stress period it is approximately one-half the pumpage in the first period.

\section{Calibration criteria}

The digital model was calibrated by adjusting values of hydraulic parameters until acceptable matches were achieved between measured and simulated static ground-water levels and drawdown. Base flow to unnamed stream 1 also was used in calibrating the model.

Water levels used in calibration of the steady-state model were measured on October 28,1998 . As explained earlier, these water levels are representative of steady-state conditions with no pumping from the irrigation well. Measured and simulated water levels at each well are listed in table 6. Simulated water levels in wells open to confining units are approximate because flow in confining units is not expressly 
Table 6. Measured and simulated water levels on October 28, 1996, and drawdown on October 29, 1996, in wells in the study area, Rutgers University Busch Campus and vicinity, Piscataway Township, New Jersey [CU, confining unit]

\begin{tabular}{|c|c|c|c|c|c|c|c|}
\hline \multirow[b]{2}{*}{$\begin{array}{l}\text { Local well } \\
\text { name }\end{array}$} & \multirow{2}{*}{$\begin{array}{l}\text { Model } \\
\text { layer } \\
\text { number }\end{array}$} & \multicolumn{3}{|c|}{$\begin{array}{l}\text { Static water level, October 28, } 1996 \\
\text { (feet above sea level) }\end{array}$} & \multicolumn{3}{|c|}{$\begin{array}{l}\text { Drawdown, October 29, } 1996 \\
\text { (feet) }\end{array}$} \\
\hline & & Measured & Simulated & $\begin{array}{l}\text { Simulated } \\
\text { minus } \\
\text { measured }\end{array}$ & Measured & Simulated & $\begin{array}{l}\text { Simulated } \\
\text { minus } \\
\text { measured }\end{array}$ \\
\hline B-1 & 1 & 75.64 & 83.64 & 8.00 & 0.15 & 0.04 & -0.11 \\
\hline B-4 & 1 & 95.54 & 88.73 & -6.81 & .05 & .09 & .04 \\
\hline B-6 & 1 & 79.92 & 80.10 & .28 & .33 & .10 & -.23 \\
\hline CH-IMW & 1 & 86.58 & 84.89 & -1.69 & .06 & .09 & .03 \\
\hline CH-2MWA & CU9 & 72.12 & 75.71 & 3.59 & 8.00 & 4.53 & -3.47 \\
\hline (4) $14141 \%$ & \% & \%6x & 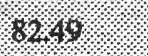 & \% & \%6 & $0 \%$ & x \\
\hline 161, & \% & \% & 10,67 & w6. & $60 \%$ & 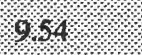 & x \\
\hline 17w & 640 & \% & 10086 & $\%$ & \%10 & \%, & \%xg \\
\hline $4 x^{2} 18$ & $16 \%$ & \% 18 & \%68 86 & Wo & \% 19 & 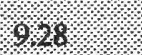 & \%60 \\
\hline $14 x+10$ & 1\% & $1 \% 60$ & $00 \%$ \% & $6 \%$ & \% & 86 & \% \\
\hline MW-2A & CU9 & 59.92 & 66.64 & 6.72 & 6.10 & 11.45 & 5.35 \\
\hline MW-2B & 9 & 61.13 & 66.71 & 5.58 & 12.73 & 12.82 & .10 \\
\hline MW-2C & CU8 & 68.21 & 70.76 & 2.55 & 3.61 & 6.43 & 2.83 \\
\hline MW-3A & CU9 & 67.91 & 68.79 & .88 & 19.04 & 9.93 & -9.11 \\
\hline$M W-3 B$ & 9 & 68.66 & 68.95 & .29 & 9.43 & 10.69 & 1.26 \\
\hline 114. & \%x & 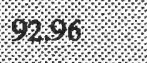 & $9 \%$ & \% 64 & \%6\% & $6 \%$ & 6 \\
\hline$h_{4}$ \% & \% & \%og & 63.3 & \%68 & 16\% & 16/8 & \%og \\
\hline 1) & \%x & 6.7.8. & $64.6 \%$ & .2. & 6.6. & $6431 \%$ & 68 \\
\hline WW: & 㭃 & $6 \%$ & $60 \%$ x & x. & W. & \% & \% \\
\hline 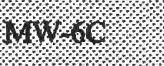 & \% & \% & $6 \%$ \% & $6 \%$ & 18: & 16, & \%66 \\
\hline MW-7A & 11 & 61.94 & 60.38 & -1.56 & 13.08 & 20.43 & 7.35 \\
\hline MW-7B & 10 & 61.92 & 64.30 & 2.38 & 8.50 & 10.36 & 1.86 \\
\hline RU-3 & 1 & 99.32 & 97.62 & -1.70 & .08 & .05 & -.03 \\
\hline RU-4 & 1 & 94.33 & 90.81 & -3.52 & 0 & .09 & .09 \\
\hline RU-5 & 9 & 73.23 & 71.08 & -2.15 & 6.81 & 9.20 & 2.39 \\
\hline
\end{tabular}


simulated in the model. The approximated water level is the average of the water levels simulated in the water-bearing units above and below the confining unit. These approximations were made to provide additional data points for calibration purposes.

All simulated water levels were within $14 \mathrm{ft}$ of the measured levels, and 60 percent were within $2.6 \mathrm{ft}$ of the measured levels. All simulated head-gradient directions matched actual gradient directions.

Base flow of $0.407 \mathrm{ft}^{3} / \mathrm{s}\left(35,200 \mathrm{ft}^{3} / \mathrm{d}\right)$ was measured in unnamed stream 1 near its confluence with the Raritan River (fig. 4) on October 28,1996 , the same day the steady-state water levels were measured. Streamflow on that day was assumed to consist entirely of base flow because only a trace of precipitation had fallen during the 8-day period preceding the measurement and because streamflow in nearby gaged streams was at base-flow conditions (R.S. Schopp, U.S. Geological Survey, oral commun., 1996). Simulated base flow at the measurement site is $32,300 \mathrm{ft}^{3} / \mathrm{d}--92$ percent of the measured base flow. Consequently, the model is considered to be adequately calibrated with respect to base flow.

The transient model was calibrated to the total drawdown observed in wells after the irrigation well had been pumped for 19 hours and 11 minutes. All simulated drawdowns were within $9.2 \mathrm{ft}$ of the measured levels, and 60 percent were within $1.9 \mathrm{ft}$ of the measured levels.

\section{Simulated Ground-Water Budget}

Data from the calibrated model can be used to estimate the ground-water-flow budget in the study area. Most of the inflow into the model area is areal recharge, and most of the outflow is discharge to the Raritan River and its tributaries. Regional flow into the model area across the northeastern boundary accounts for the rest of the inflow, and pumping from wells accounts for the rest of the outflow. When the irrigation well is pumped at its average annual rate, 78 percent of the water captured by the well is intercepted base flow to unnamed stream 1. The remainder is intercepted base flow to the Raritan River. Budgets for the simulations with no pumping and with average annual pumpage from the irrigation well are shown schematically in figure 8 .

\section{GROUND-WATER QUALITY AND DISTRIBUTION OF VOLATILE ORGANIC COMPOUNDS}

Water samples were collected from each accessible well in the study area at least once during 1993-96 and analyzed for VOC's. Samples were collected from 15 wells during August-September 1993, from 17 wells during June-July 1994, from 24 wells in 1995, and from 25 wells in 1996. The shallow upgradient well (MW-4) was sampled twice in 1995 because attempts to sample this well in 1993 and 1994 were not successful because of its low yield.

\section{Ground-Water Quality}

All water samples were analyzed for VOC's. Eleven VOC's were present at concentrations above the reporting limit (table 7, at end of report). The reporting limits of these 11 compounds, as well as the 48 VOC's for which the samples were analyzed but were not detected in concentrations above the reporting limit, are listed in appendix 2. The areal distribution of VOC's in the study area did not vary greatly from 1993 to 1996.

Samples from 12 of the wells in the study area were analyzed for dissolved cations, anions, nutrients, metallic trace elements, and phenols, and samples from 11 wells were analyzed for polychlorinated biphenyls. Results of these analyses are listed in appendix 3 . No primary maximum contaminant level (MCL) for any of these constituents was exceeded in any 


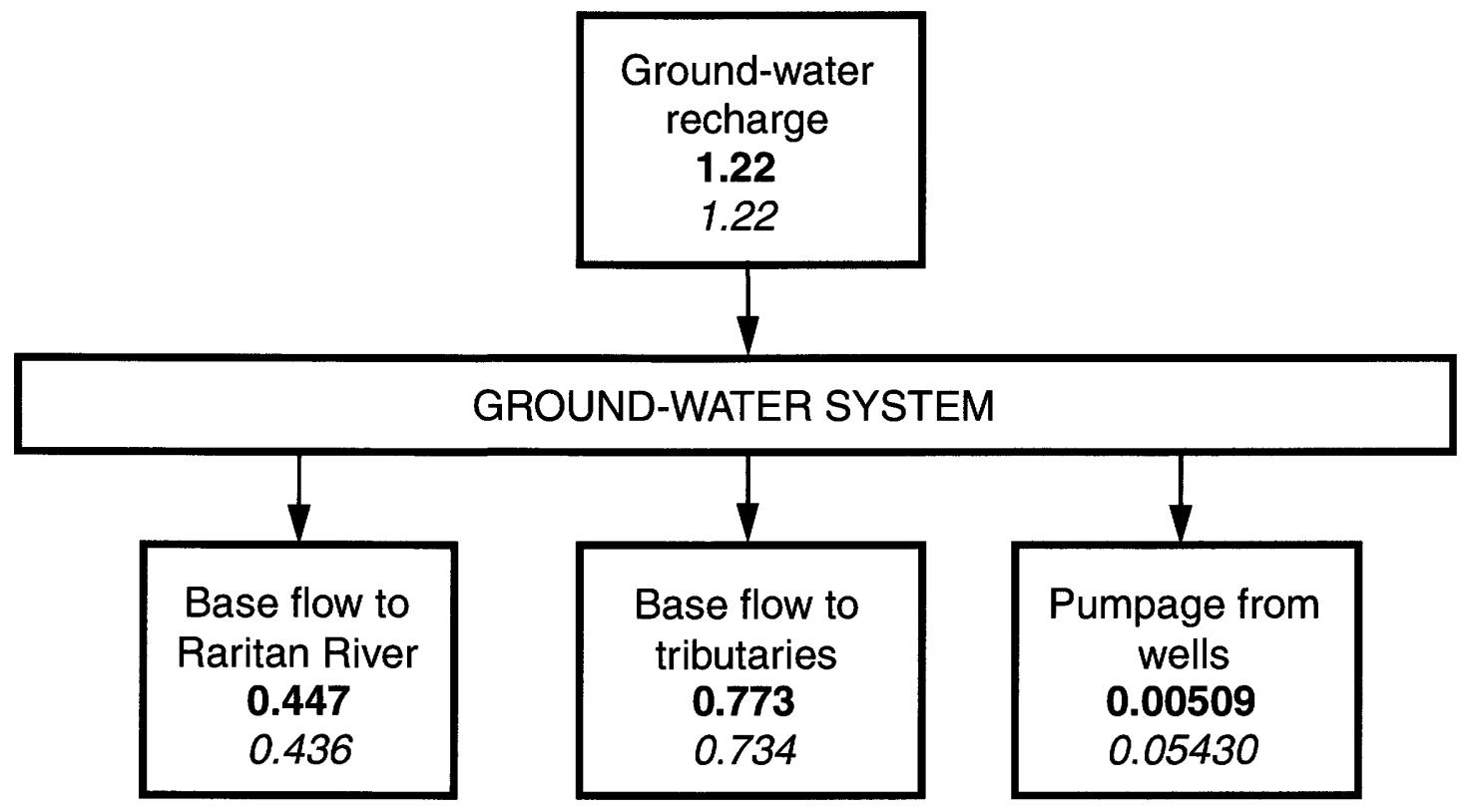

\section{EXPLANATION}

1.22 No pumpage at irrigation well.

Value in cubic feet per second

1.22 Average annual pumpage at irrigation well.

Value in cubic feet per second

Figure 8. Simulated ground-water budget, Rutgers University Busch Campus and vicinity, Piscataway Township, New Jersey. 
of these samples, and no polychlorinated biphenyls were detected in any sample. The MCL is the maximum concentration of a constituent allowable in public drinking water. MCLs are generally based on health criteria. MCLs for selected inorganic constituents and organic compounds are listed in appendix 4.

\section{Quality Assurance Procedures}

VOC-concentration data were reviewed to verify the results of the laboratory analyses. Recoveries of the surrogate analyte added to all samples prior to analysis as well as the accuracy of the measurement of compounds of interest in the laboratory-fortified blanks were within accepted precision limits.

Twelve sequential replicate samples were submitted blind to the laboratory for analysis for VOC's during 1993-96. Results of analyses of these samples are included in table 7 . Of the 708 sets of analyses (including those for compounds listed in appendix 2 that were not detected in any sample), 688 were duplicated exactly. Only two sets of analyses had relative percent differences greater than 27 percent; these two were analyses for methylene chloride, a common laboratory contaminant. For the purposes of this study, the quality of the replicate analyses are acceptable.

Thirty-one field blanks and 23 trip blanks also were submitted for VOC analysis. Results of these analyses are presented in appendix 5 . Methylene chloride was the prevalent compound found in blanks; this compound was detected in concentrations up to $6.3 \mu \mathrm{g} / \mathrm{L}$ in 13 field blanks and up to $5.0 \mu \mathrm{g} / \mathrm{L}$ in 9 trip blanks. In most cases, methylene chloride was detected also in the associated laboratory method blank; therefore, occurrence of this compound in blanks is attributed to contamination originating in the analyzing laboratory. A concentration of $0.6 \mu \mathrm{g} / \mathrm{L}$ of chloroform was detected in the trip blank for September 19, 1995, and a concentration of $0.6 \mu \mathrm{g} / \mathrm{L}$ of 1,2-dichloropro- pane was detected in the trip blank for October 4, 1996, but neither of these compounds was detected in other samples in the same shipments. No other organic compounds were detected.

As a simple check on analyte loss during transportation and laboratory holding time and on GC/MS accuracy, samples collected from two wells (MW-2A and CH3-MW) in 1995 were spiked in the field with a known concentration of an organic compound. The only compound detected in these two samples was this field surrogate; percent recoveries for this surrogate were 100 and 87 percent, respectively.

\section{Distribution of Volatile Organic Compounds}

\section{Carbon tetrachloride and tetrachloroethylene}

Carbon tetrachloride was detected at higher concentrations than any other VOC and was detected in samples from 5 wells. Concentrations of this compound ranged from less than $0.5 \mu \mathrm{g} / \mathrm{L}$ to $24,000 \mu \mathrm{g} / \mathrm{L}$ and were highest in samples from wells less than $10 \mathrm{ft}$ from the $\mathrm{C}$ Wing building--RU-2, RU-4, and RU-5. These wells are 27,27 , and $75 \mathrm{ft}$ deep, respectively. Concentrations of carbon tetrachloride in all samples from these wells greatly exceeded the MCL of $2.0 \mu \mathrm{g} / \mathrm{L}$ (New Jersey Administrative Code, 1990). Carbon tetrachloride also was detected consistently in samples from well MW-3B, which is $750 \mathrm{ft}$ from the C-Wing building and $90 \mathrm{ft}$ deep, and intermittently in samples from well MW-1A, which is $370 \mathrm{ft}$ from the $\mathrm{C}$-Wing building and $100 \mathrm{ft}$ deep. The concentrations of carbon tetrachloride in all samples from these two wells were below the MCL. Trace amounts of carbon tetrachloride (below the reporting limit of $0.5 \mu \mathrm{g} / \mathrm{L}$ ) were detected in water from wells MW-1A, MW-3A, MW-2B, and MW-2C in 1993. These wells are $330,750,1,380$, and $1,380 \mathrm{ft}$ from the $\mathrm{C}$-Wing building and are 100,140,110, and $80 \mathrm{ft}$ deep, respectively. 
Well MW-5A, which was installed in 1995 to help define the vertical distribution of contaminants near the $\mathrm{C}$-Wing building, is screened from 179 to $204 \mathrm{ft}$ below land surface. It is more than $100 \mathrm{ft}$ deeper than the adjacent well, RU-5, which is $75 \mathrm{ft}$ deep. The sample from well MW-5A contained no detectable carbon tetrachloride although the samples from well RU-5 contained up to $8,500 \mu \mathrm{g} / \mathrm{L}$ of this compound.

The analytical data indicate that the carbon tetrachloride contaminant plume--as defined by points where this compound has been detected at concentrations exceeding the MCL--is localized in an area within $10 \mathrm{ft}$ of the C-Wing building and to a depth of somewhere between 75 and $179 \mathrm{ft}$.

The areal distribution of PCE is very different from and much more discontinuous than the distribution of carbon tetrachloride. PCE, the most frequently detected compound, was present in 22 samples from nine wells in concentrations ranging from less than 0.5 to 1,300 $\mu \mathrm{g} / \mathrm{L}$. PCE was detected in concentrations exceeding the MCL $(1.0 \mu \mathrm{g} / \mathrm{L})$ in all samples from wells RU2, RU-4, RU-5, MW-5A, CH$2 \mathrm{MWB}$, and the irrigation well. These wells are 5 to $2,370 \mathrm{ft}$ from the $\mathrm{C}$-Wing building and 27 to $300 \mathrm{ft}$ deep.

Concentrations of PCE were highest in samples from wells less than $10 \mathrm{ft}$ from the $\mathrm{C}$ Wing building--RU-2, RU-4, and RU-5, which are 27,27 , and $75 \mathrm{ft}$ deep, respectively. The sample from well MW-5A, the 204-ft-deep well near the $\mathrm{C}$-Wing building, contained $1.4 \mu \mathrm{g} / \mathrm{L}$ of PCE. The presence of PCE, but not carbon tetrachloride, at this depth may be the result of an earlier release time for PCE or its slightly greater specific density ( 1.63 compared to 1.59 ) and lower viscosity.

The next highest concentrations of PCE were found in the irrigation well, which is $2,370 \mathrm{ft}$ from the C-Wing building. PCE concentrations detected in this well range from 16 to $23 \mu \mathrm{g} / \mathrm{L}$. The irrigation well is $300 \mathrm{ft}$ deep and open to water-bearing units 9-12.

No PCE was detected in many wells between the $\mathrm{C}$-Wing building and the irrigation well (all wells in clusters MW- 1 and MW-3 and the deepest wells in clusters MW-2 and MW-6). Moreover, where PCE was detected in wells between the C-Wing building and the irrigation well, concentrations were low (at or below the MCL). At the well cluster closest to the irrigation well, PCE was detected at $0.5 \mu \mathrm{g} / \mathrm{L}$ in well MW-6C, which is open to water-bearing unit 9, but was not detected in samples from the two deeper wells open to water-bearing units 11 and 12.

PCE also was consistently present in samples from Rutgers golf 13 obs. This well is 200 $\mathrm{ft}$ deep, open to water-bearing units 9-11, and $2,500 \mathrm{ft}$ from the $\mathrm{C}$-Wing building--farther from the building than is the irrigation well. Concentrations of PCE in samples from this well are either slightly above or below the MCL.

\section{Other volatile organic compounds}

Four other VOC's were detected in concentrations exceeding their MCL's. Trichloroethylene (TCE) was detected in concentrations exceeding the MCL $(1.0 \mu \mathrm{g} / \mathrm{L})$ in water from well MW-5A in 1995 and 1996, from RU-4 in 1994, and from well CH-1MW in 1993. TCE was detected in a concentration below the MCL in water from well RU-5 in 1994. TCE in the study area commonly is associated with PCE and cis-1,2-dichloroethene. PCE degrades to TCE, to the 1,2-dichloroethenes, and finally to vinyl chloride by the process of reductive dehalogenation (Freedman and Gossett, 1989). Therefore, TCE in the study area probably is a degradation product of $\mathrm{PCE}$.

Benzene was detected in samples from two wells in concentrations greater than the MCL of $1.0 \mu \mathrm{g} / \mathrm{L}$-well CH-1MW in $1993(2.9 \mu \mathrm{g} / \mathrm{L})$ and well RU-4 in $1994(3.4 \mu \mathrm{g} / \mathrm{L})$. The 1994 
water sample from well RU-4 also contained $36 \mu \mathrm{g} / \mathrm{L}$ of 1,2-dichloroethane, which exceeds the MCL of $2.0 \mu \mathrm{g} / \mathrm{L}$. These results, however, were not duplicated in previous or subsequent sampling. The only water sample in which the MCL of $100 \mu \mathrm{g} / \mathrm{L}$ for total trihalomethanes was exceeded was collected from well RU-2 in 1994. Chloroform, one of the trihalomethanes, was detected in this sample at a concentration of $110 \mu \mathrm{g} / \mathrm{L}$.

The only VOC's detected at the MW-7 well cluster were toluene and chloroform. These compounds were detected in concentrations of 29 and $0.6 \mu \mathrm{g} / \mathrm{L}$, respectively, which are far below the MCL's of 1,000 and $100 \mu \mathrm{g} / \mathrm{L}$. This well cluster is between the CWing building and the domestic wells but is much closer to the domestic wells. It was installed to serve as an early warning to detect any contaminants that may be moving from the C-Wing building area toward the domestic wells.

\section{Relation of Distribution of Contaminants to Ground-Water Flow Paths}

The digital model was used to approximate the configuration of ground-water-flow paths from the vicinity of the $\mathrm{C}$-Wing building. These approximations were made to determine whether the broken sump pipe at the C-Wing building is a plausible source of all carbon tetrachloride and PCE detected in wells in the study area and to estimate the effects of pumping on flow paths. MODPATH, a particle-tracking post-processor for MODFLOW developed by Pollack (1994), was used to compute the paths. Actual ground-water flow paths through the fractured-rock aquifer system are undoubtedly more complex than the simulated paths; however, the simulated paths are considered the best available estimate of the general configuration of flow paths on the scale of the study area.

Both of the primary contaminants at the CWing building--carbon tetrachloride and PCE-- are dense nonaqueous-phase liquids (DNAPLs). Although these compounds have been detected in the study area only in the dissolved phase, it is possible that undissolved masses of these DNAPLs are present near their assumed source area. Because undissolved DNAPLs are denser than water, they move in different directions and at different velocities than the surrounding water. Their density causes them to move more slowly and have a greater downward vertical component of flow than the surrounding water. As water flows past the DNAPLs, it dissolves the DNAPLs, which can then move advectively with the water. The digital model used in this study simulates only the advective transport of dissolved contaminants--it cannot predict the movement of the undissolved DNAPLs. Therefore, it is necessary to estimate the "assumed source area" over which undissolved DNAPLs are present in order to use the model to estimate advective flow paths beginning at the source area.

Kueper and McWhorter (1991) found that DNAPLs travel along dipping fracture planes at a speed directly proportional to the dip of the plane from the horizontal. They also found that DNAPLs tend to pool above confining units but that if a DNAPL encounters an open fracture in the confining unit it may move through the fracture to lower water-bearing units. These findings were used to estimate the potential movement of DNAPLs from the site of the broken sump pipe at the $\mathrm{C}$-Wing building. If any DNAPL were present, it probably would move along bedding-plane fractures in the waterbearing units in the direction of the dip of the bedrock (northwest) and also downward through vertical fractures in confining units. Consequently, any DNAPLs that ever were present near the broken sump pipe probably have moved both to the northwest and vertically downward. The extent of this movement is unknown, but water-quality data for wells RU-5 and MW5-A indicate that the maximum depth of dissolved carbon tetrachloride is 
somewhere between the bottom of water-bearing unit 9 and the top of water-bearing unit 11 and that the maximum depth of dissolved PCE is approximately at the bottom of water-bearing unit 11. Water-quality data from well $\mathrm{CH} 3-\mathrm{MW}$ indicate that both contaminants have moved less than $500 \mathrm{ft}$ downdip. Consequently, the assumed source area of undissolved carbon tetrachloride was conservatively estimated to extend $130 \mathrm{ft}$ below and $250 \mathrm{ft}$ northwest from the broken sump pipe. Similarly, the assumed source area of PCE was estimated to extend $200 \mathrm{ft}$ below and $250 \mathrm{ft}$ northwest from the broken sump pipe.

The flow paths were estimated from simulations of the ground-water system under three hypothetical steady-state conditions. In all three simulations, 11 domestic wells in the model area are pumped. In Simulation 1, the irrigation well is not pumped; in Simulation 2, the irrigation well is pumped at the average yearly rate (22.1 gal $/ \mathrm{min})$; and in Simulation 3 , the irrigation well is pumped at a rate equal to its maximum short-term yield ( $262 \mathrm{gal} / \mathrm{min}$ ). It is not known, however, whether this pumping rate could actually be sustained in the well or whether the drawdown caused by the pumping would adversely affect yields in the domestic wells.

Three different pumping rates were simulated because actual pumping from the irrigation well is intermittent. The well is pumped only during late April through October, and during those months it is pumped only when precipitation is inadequate to maintain grass on the golf course. Even at those times, the well is pumped for a maximum of about 16 hours per day. Consequently, steady-state ground-water conditions probably occur only rarely during the spring, summer, and fall. The simulated flow paths under the two "end-member" conditions--no pumping and maximum pumping-provide a reasonable range of actual flow paths of water from the $\mathrm{C}$-Wing building. The simulated flow paths under the average-yearly- pumpage condition provide an intermediate estimate of actual flow paths.

\section{Carbon tetrachloride}

Simulated paths of ground-water flow from the assumed carbon tetrachloride source area in the three simulated pumping conditions are shown in map view in figures 9-11. Only a few representative flow paths, including the two outermost paths, are shown. The two outermost flow paths enclose the entire simulated area through which water from the $\mathrm{C}$-wing building could flow. In all three simulations, flow lines trend predominantly northeast to southwest--parallel to the strike of the waterbearing units. This predominant flow direction is consistent with the conceptual model and is a result of the dip of the water-bearing units and confining units that make up the hydrogeologic framework.

Pumping from the irrigation well affects the configuration of the simulated flow paths. When the well is not pumped, all water that passes through the assumed carbon tetrachloride source area flows generally southwest and discharges to unnamed stream 1 . Water originating in the weathered part of the carbon tetrachloride source area flows nearly vertically from the weathered zone into the underlying water-bearing unit (unit 9). Most of the water flows through unit 9 to the unit's outcrop in unnamed stream 1, where it discharges to the stream, but some water from the southeasternmost part of the source area flows from unit 9 to unit 10 and back to unit 9 before discharging to the stream. It is unlikely that water reaching the stream from the $\mathrm{C}$-wing building still contains carbon tetrachloride because this compound has not been detected in concentrations above the MCL at distances greater than $10 \mathrm{ft}$ from the building.

In the model simulation in which the irrigation well is pumped at the average annual rate, all water from the assumed source area 


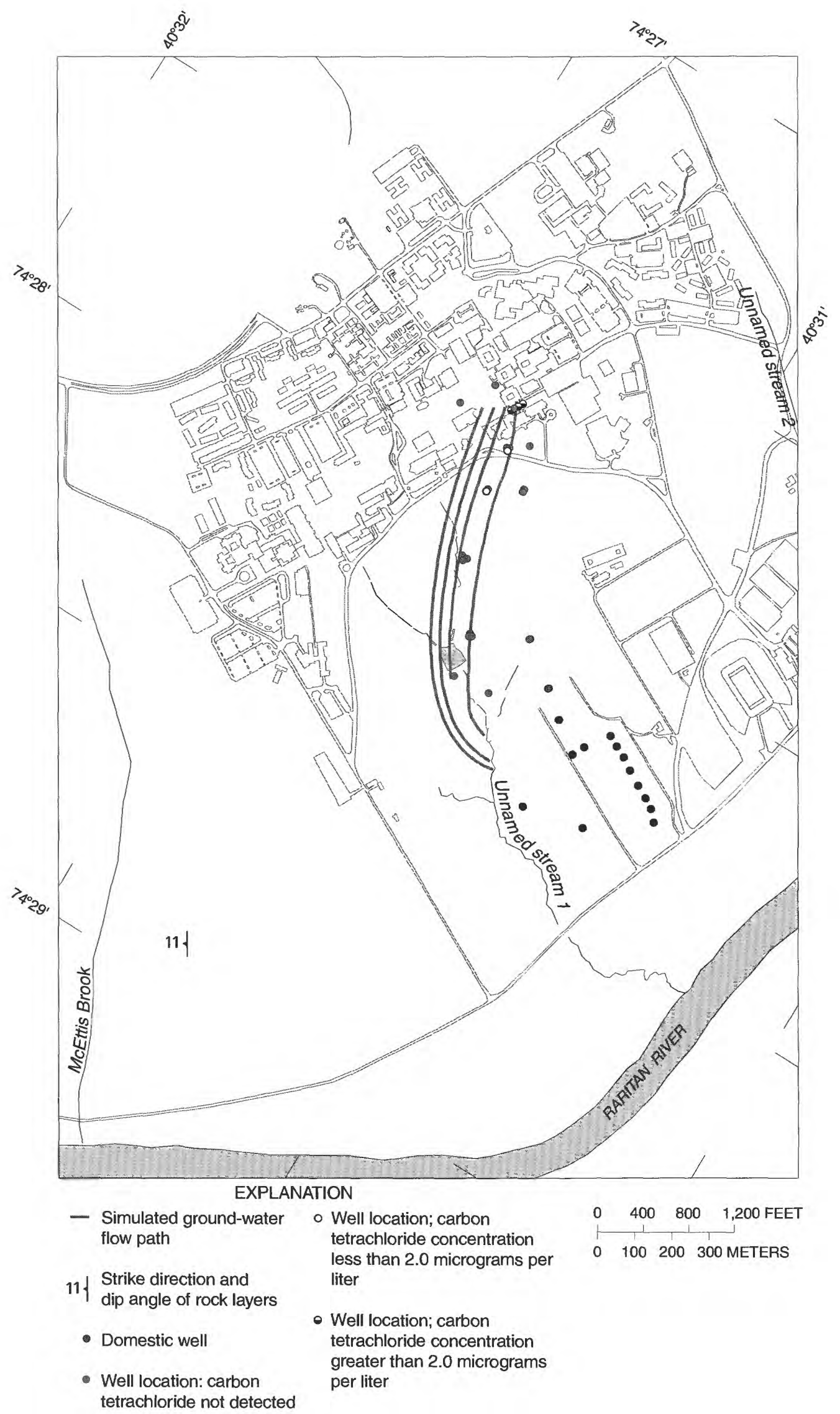

Figure 9. Concentration of carbon tetrachloride in water samples collected from wells in 1995 and simulated ground-water flow paths from the assumed carbon tetrachloride source area under steady-state conditions with no pumpage from the irrigation well, Rutgers University Busch Campus and vicinity, Piscataway Township, New Jersey. 


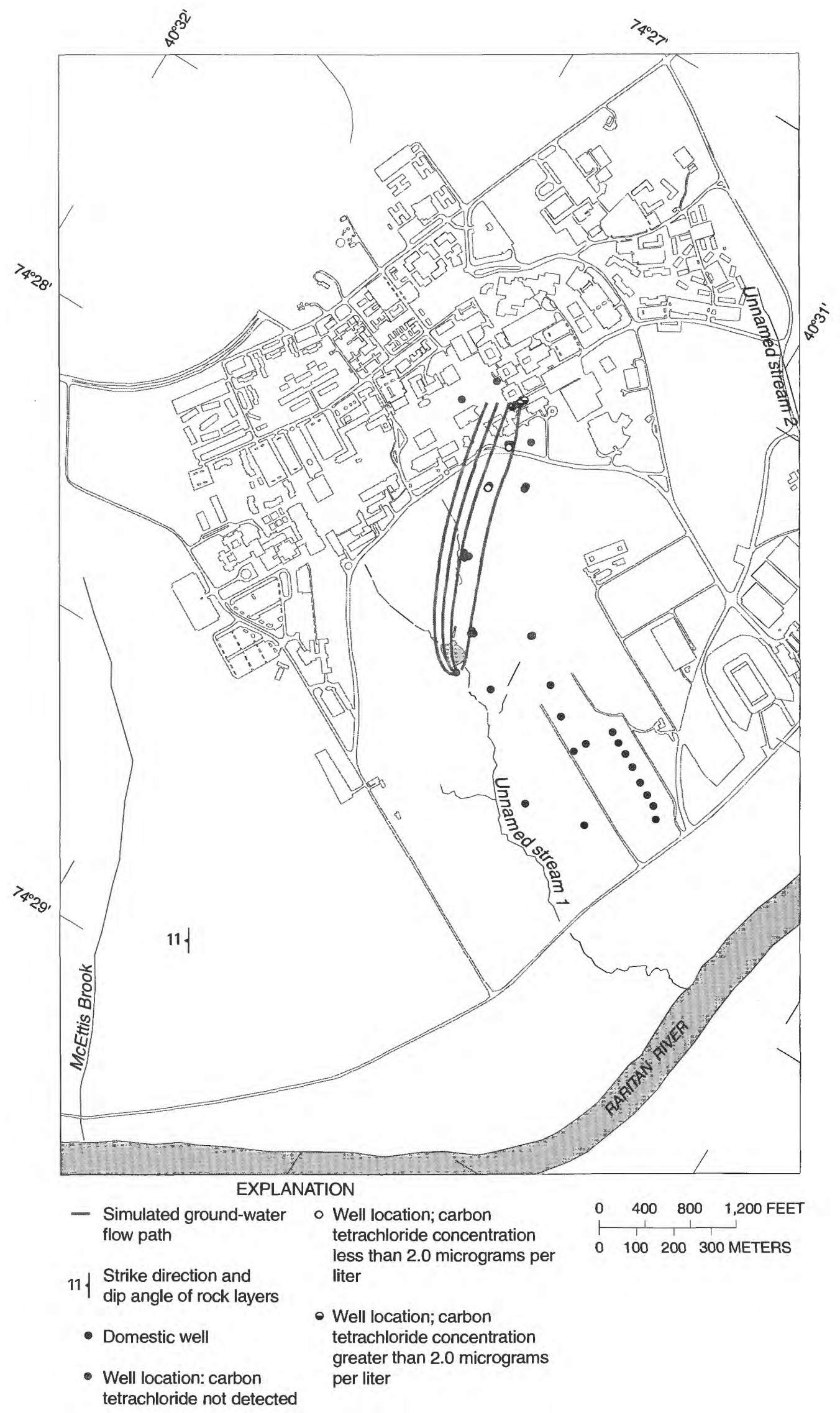

Figure 10. Concentration of carbon tetrachloride in water samples collected from wells in 1995 and simulated ground-water flow paths from the assumed carbon tetrachloride source area under steady-state conditions with average annual pumpage from the irrigation well, Rutgers University Busch Campus and vicinity, Piscataway Township, New Jersey. 


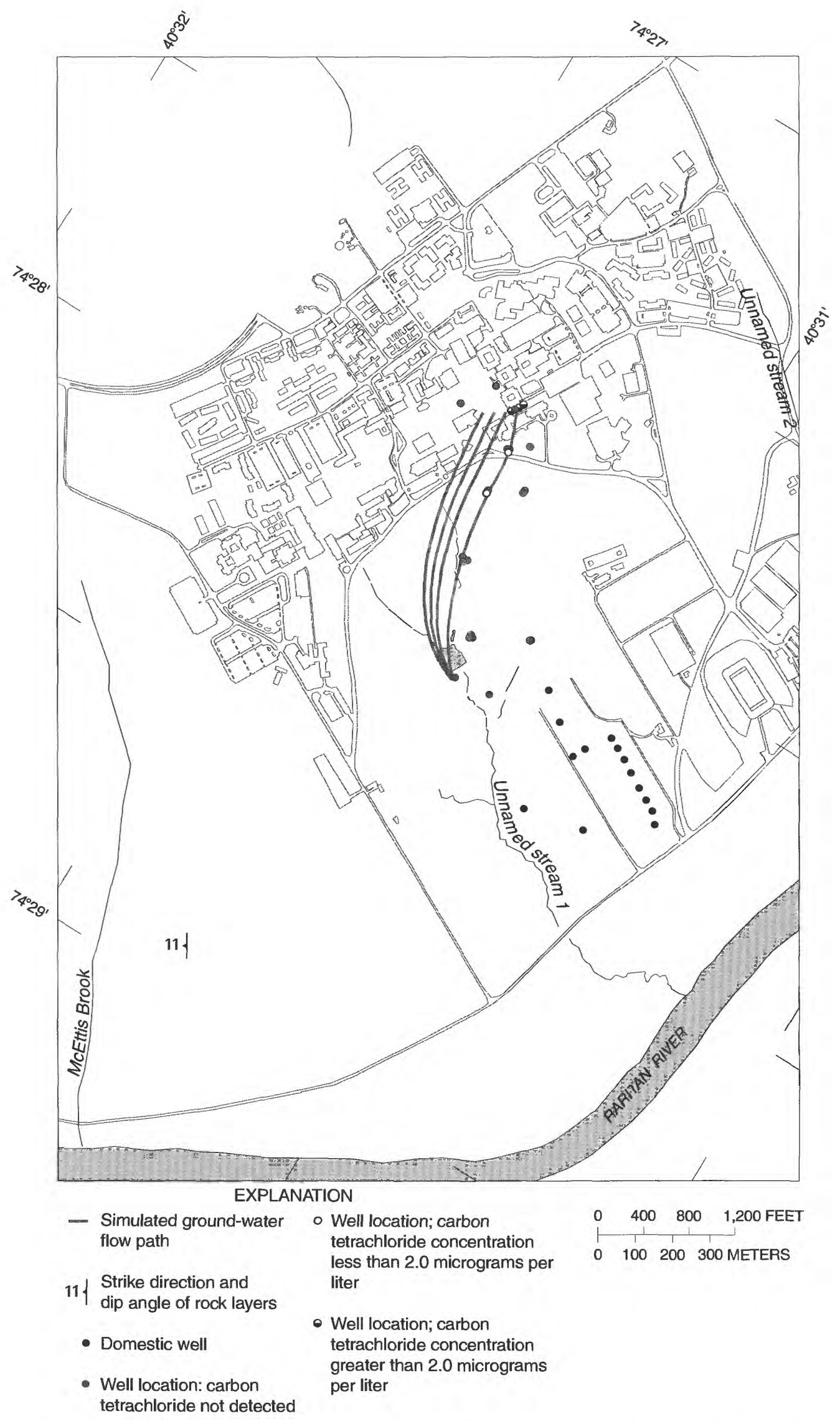

Figure 11. Concentration of carbon tetrachloride in water samples collected from wells in 1995 and simulated ground-water flow paths from the assumed carbon tetrachloride source area under steady-state conditions with maximum pumpage from the irrigation well, Rutgers University Busch Campus and vicinity, Piscataway Township, New Jersey. 
discharges to the irrigation well, which is open to water-bearing units 9-12, and all paths remain in water-bearing unit 9 . In the model simulation in which the irrigation well is pumped continuously at its maximum shortterm yield, flow paths follow the same pattern but are farther downdip, toward the northwest, as a result of drawdown in the vicinity of the irrigation well.

The concentrations of carbon tetrachloride (greater than $2 \mu \mathrm{g} / \mathrm{L}$, less than $2 \mu \mathrm{g} / \mathrm{L}$, or not detected) in samples from wells also are shown in figures 9-11. All wells in which carbon tetrachloride was detected are within the area encompassed by the flow lines from the assumed carbon tetrachloride source area, and the concentrations of carbon tetrachloride decrease along flow paths. Consequently, the flow-path analysis supports the hypothesis that all the carbon tetrachloride detected in the study area originated at the broken pipe near the $\mathrm{C}$-Wing building.

In all three pumping simulations, none of the flow paths from the assumed carbon tetrachloride source area (figs. 9-11) reaches any domestic well. The shortest distance between a flow path and a domestic well in any of the simulations is about $700 \mathrm{ft}$. That flow path was generated in the simulation with no pumping from the irrigation well. The simulation results show that pumping from the irrigation well widens the distance between flow paths of potentially contaminated water and the domestic wells.

A section view through the study area showing the extent of the simulated flow paths from the assumed carbon tetrachloride source area with no pumping from the irrigation well and concentrations of carbon tetrachloride in samples from wells are shown in figure 12. As in the map views (figs. 9-11), all wells in which carbon tetrachloride was detected are within the area encompassed by the flow lines from the carbon tetrachloride source area, and concentrations decrease along flow lines. The same information for both the average-annual-pump- age and maximum-pumpage simulations is shown in figure 13 . The area that includes the flow lines is identical in these two simulations, and, as in the no-pumping simulation, all wells in which carbon tetrachloride was detected are located within this area.

\section{Tetrachloroethylene}

Simulated paths of ground-water flow from the assumed PCE source area in the three steady-state simulations are shown in map view in figures 14-16. Flow paths from the assumed PCE source area are more numerous than those from the assumed carbon tetrachloride source area because the PCE source area encompasses two additional water-bearing units--units 10 and 11. In the simulation with no pumping from the irrigation well (fig. 14), the discharge points of flow paths in units 10 and 11 are farther southwest than the discharge points of flow paths in unit 9 because these units crop out farther southwest than does unit 9; paths in unit 11 extend to the Raritan River (fig. 14).

When the irrigation well is pumped at its average annual rate, most of the flow paths originating in the assumed PCE source area are captured by the well (fig. 15); when the well is pumped at a rate equal to its maximum shortterm yield, all of the flow paths are captured (fig. 16). Like the flow paths originating in the assumed carbon tetrachloride source area, paths originating in the PCE source area shift to the northwest as pumpage from the irrigation well increases.

The concentrations of PCE detected in samples from wells are also shown in figures 14-16. The distribution of PCE, unlike the distribution of carbon tetrachloride, is complex and discontinuous. PCE was detected in concentrations above the $1.0 \mu \mathrm{g} / \mathrm{L}$ MCL in samples from wells as far as $2,500 \mathrm{ft}$ from the $\mathrm{C}$-Wing building but not at several wells closer to the CWing building (fig. 14). In addition, simulated ground-water flow paths from the building area do not encompass all of the wells in which PCE was detected. 


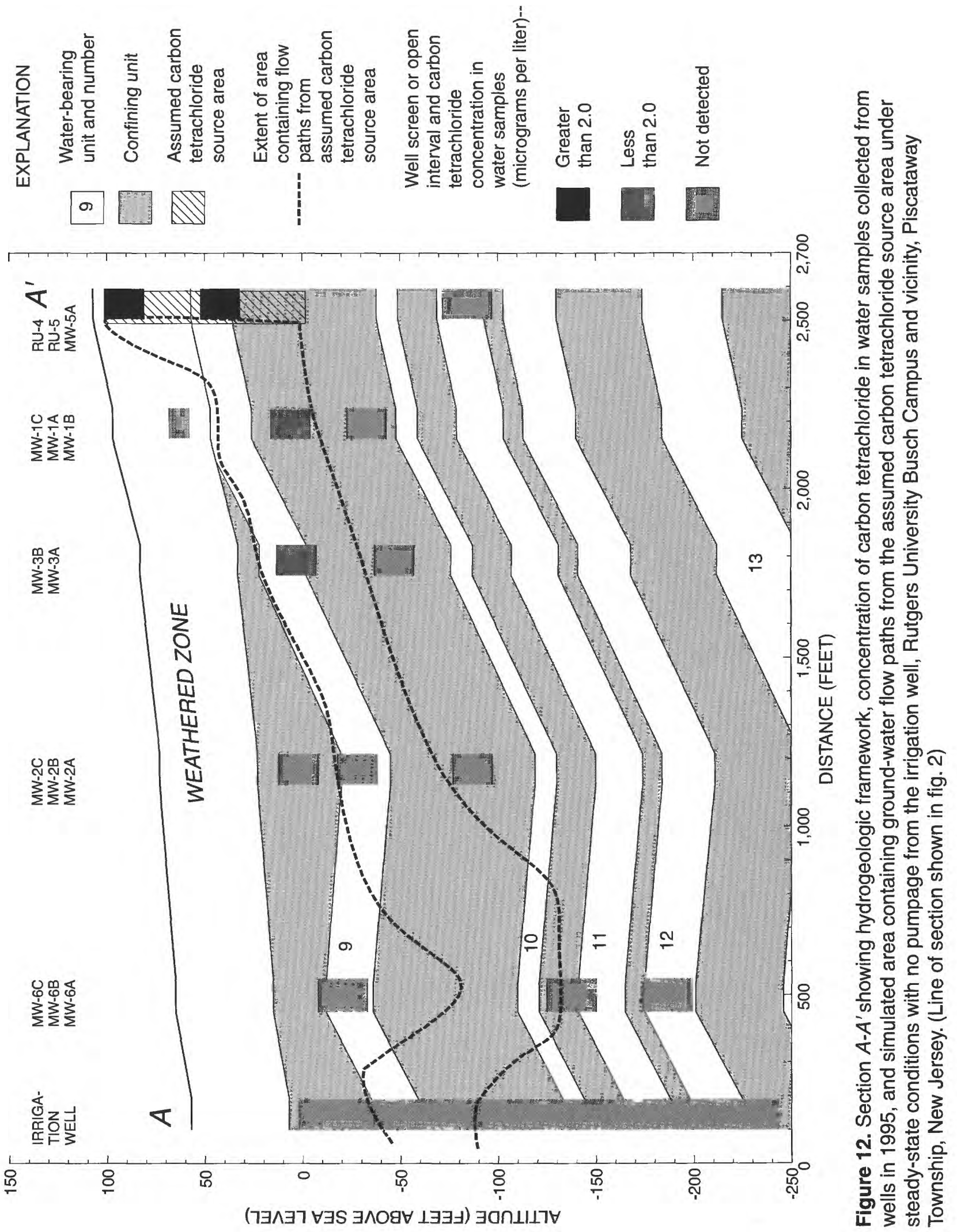




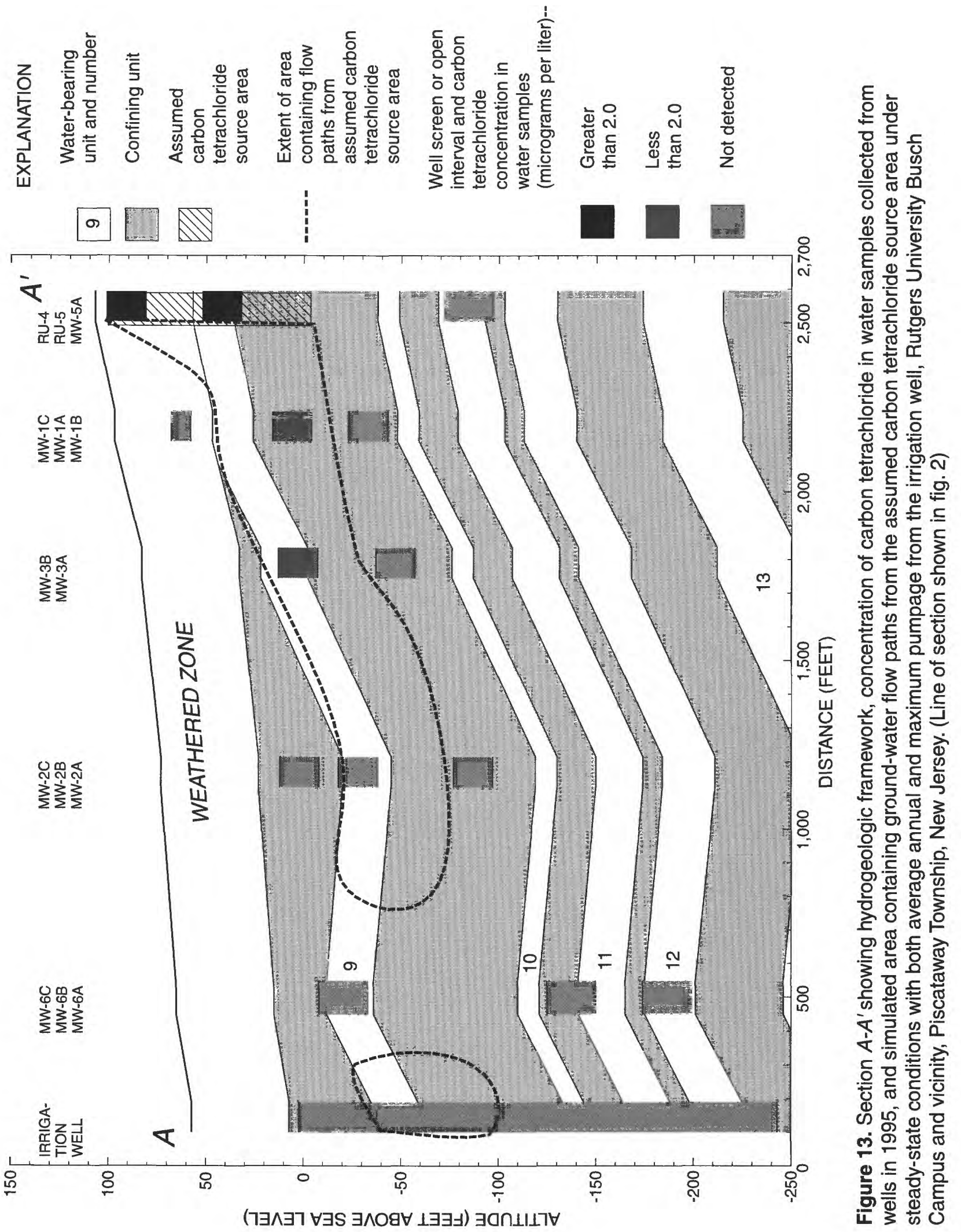




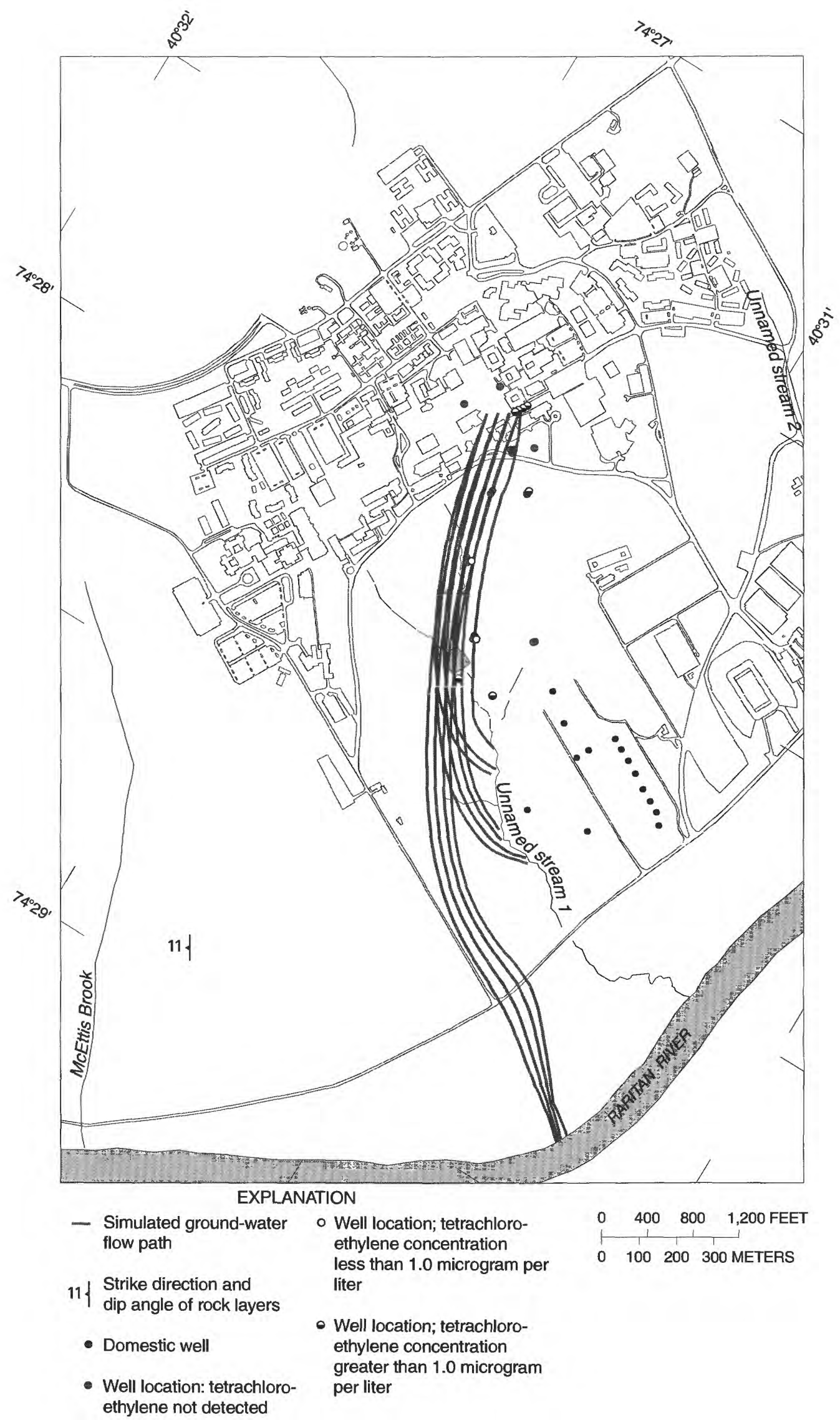

Figure 14. Concentration of tetrachloroethlyene in water samples collected from wells in 1995 and simulated ground-water flow paths from the assumed tetrachloroethlyene source area under steady-state conditions with no pumpage from the irrigation well, Rutgers University Busch Campus and vicinity, Piscataway Township, New Jersey. 


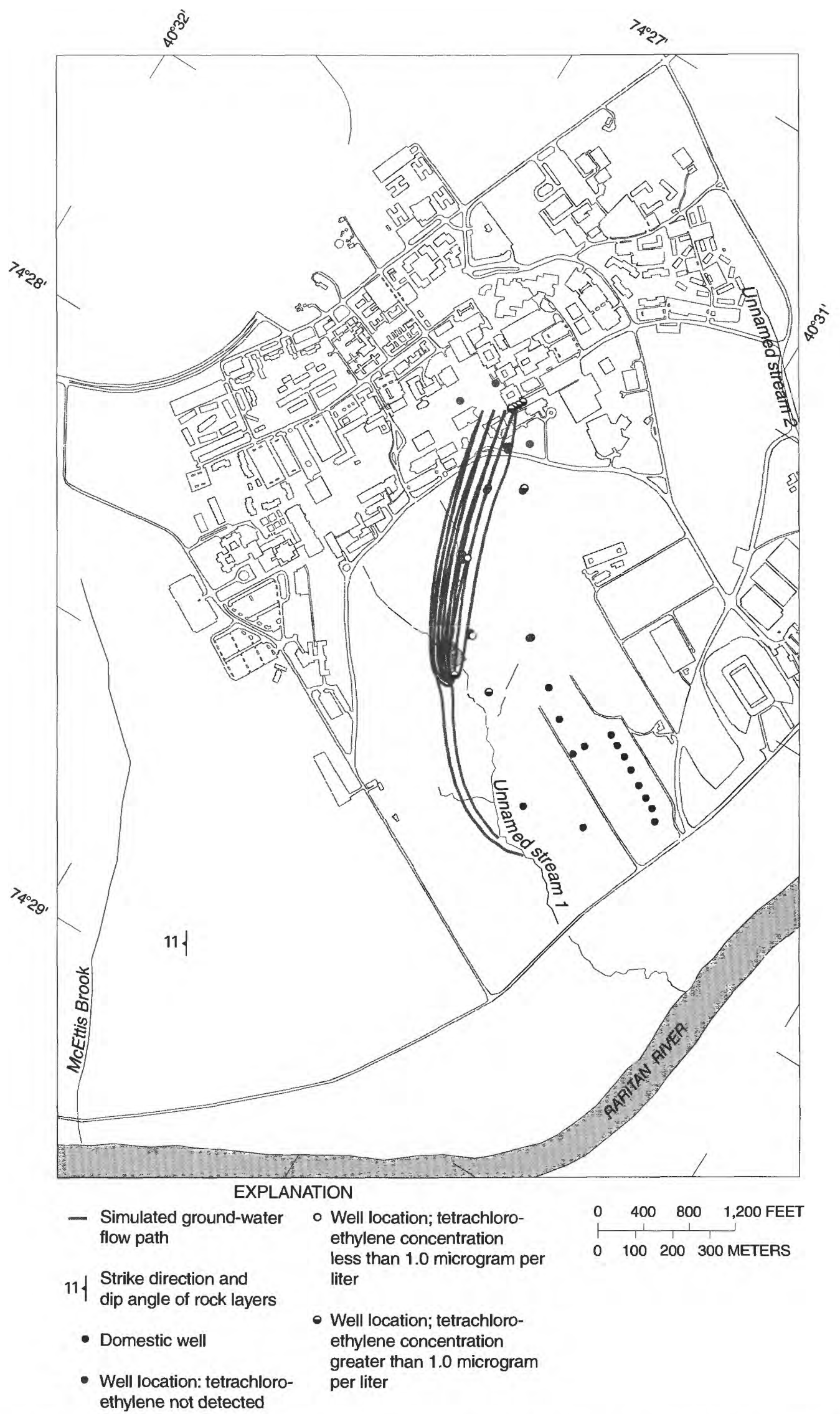

Figure 15. Concentration of tetrachloroethlyene in water samples collected from wells in 1995 and simulated ground-water flow paths from the assumed tetrachloroethlyene source area under steady-state conditions with average annual pumpage from the irrigation well, Rutgers University 


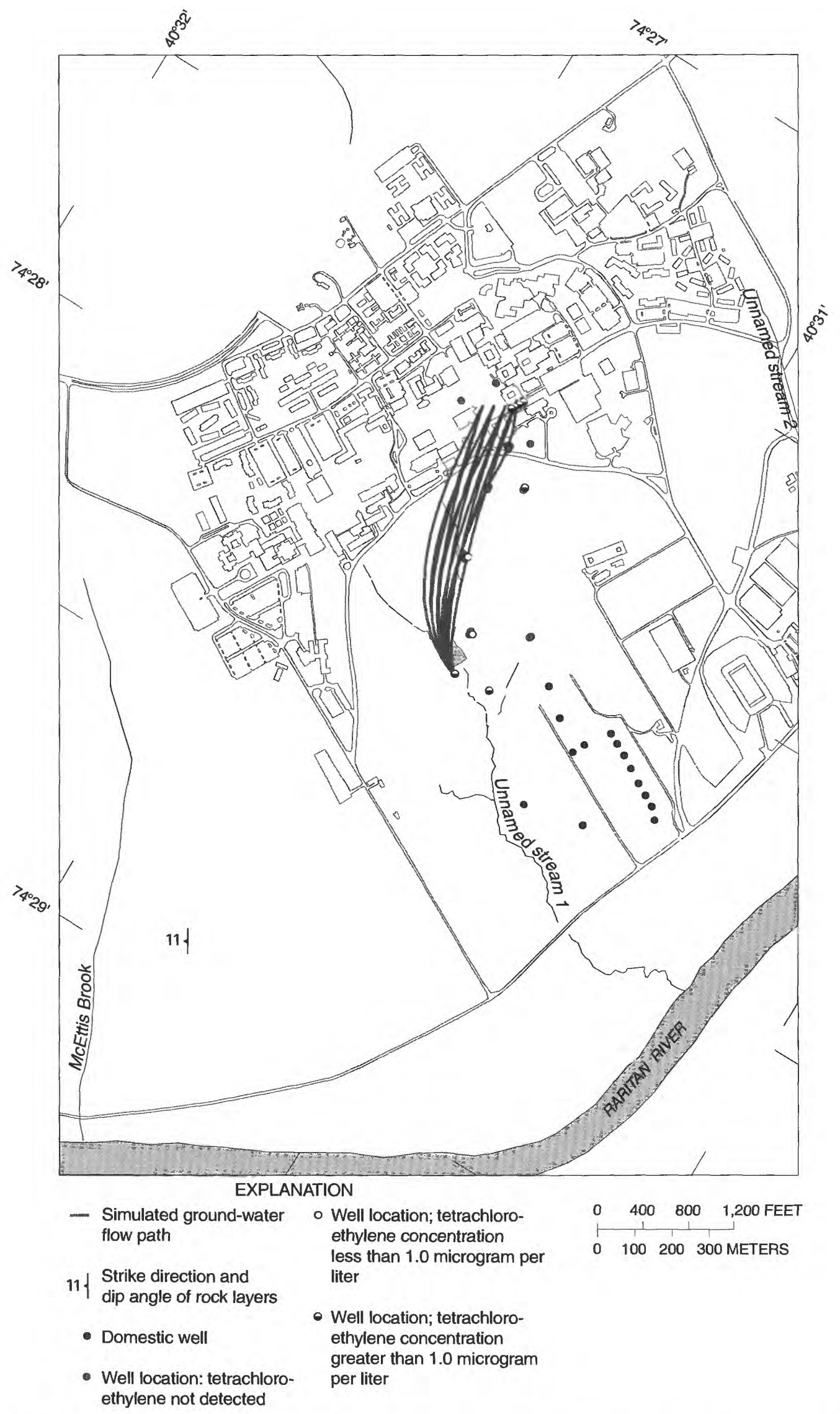

Figure 16. Concentration of tetrachloroethlyene in water samples collected from wells in 1995 and simulated ground-water flow paths from the assumed tetrachloroethlyene source area under steady-state conditions with maximum pumpage from the irrigation well, Rutgers University Busch Campus and vicinity, Piscataway Township, New Jersey. 
A section view through the study area showing the area containing simulated flow paths from the assumed PCE source area in the no-pumping simulation and concentrations of PCE detected in samples from wells are shown in figure 17. The same information for both the average-annual-pumpage and maximumpumpage simulations is shown in figure 18. As in the map views (figs. 14-16), some wells in which PCE was detected are outside the area encompassed by the flow lines from the assumed source area. Consequently, the distribution of PCE and the simulated flow paths are inconsistent with the hypothesis that all the PCE detected in the study area originated at the broken pipe near the C-Wing building. As described earlier, however, simulations of ground-water flow through fractured rocks cannot exactly duplicate the actual paths. Consequently, the possibility that all PCE found in the study area is derived from the C-Wing building area cannot be conclusively ruled out.

\section{SUMMARY AND CONCLUSIONS}

Volatile organic compounds, primarily carbon tetrachloride and tetrachloroethylene (PCE), were detected in shallow ground water near the Chemical Engineering building--also called the C-Wing building-at the Rutgers University Busch Campus in Piscataway Township, Middlesex County, New Jersey. The C-Wing building overlies the Passaic Formation, which comprises a water-supply aquifer, and is about $2,500 \mathrm{ft}$ north-northeast of several domestic wells. During 1993-96, the U.S. Geological Survey, in cooperation with Rutgers, the State University of New Jersey, conducted field investigations and data analysis to determine the extent and distribution of contamination and characteristics of the ground-water flow system in a study area comprising $0.3 \mathrm{mi}^{2}$ in the vicinity of the Busch Campus. Field investigations included geologic coring, collection of borehole-geophysical logs, installation of monitor wells, measurement of ground-water levels and streamflow, aquifer testing, and collection of water-quality samples.

In the study area, the Passaic Formation consists of dipping layers of extensively fractured coarse-grained siltstone and sandstone interbedded with layers of sparsely fractured, finer grained siltstone and mudstone. Ground water is primarily stored in and transmitted through interconnected fractures in these rocks. The rocks are weathered near land surface. Clay and silt derived from the weathering process fills many of the fractures in the weathered zone, causing it to be less permeable than the underlying water-bearing units.

At least 23 fracture zones are present in the study area. Transmissivity data from wells completed in these zones, however, indicate that only four of these fracture zones are actually water-bearing units. No other fracture zones transmit significant volumes of water and all are within confining units. The median transmissivity of zones identified as waterbearing units and confining units, respectively, is 84 and $3.7 \mathrm{ft}^{2} / \mathrm{d}$. The median transmissivity of the weathered zone is $4.8 \mathrm{ft}^{2} / \mathrm{d}$.

Recharge to the ground-water system is by downward leakage of infiltrated precipitation. The transmissivity contrasts and the dipping hydrogeologic units of the multiunit aquifer system cause large-scale anisotropic flow. Ground-water flow through the system is predominantly southwest, parallel to the strike of the rock layers. Discharge is predominantly to the Raritan River and its tributaries; minor amounts flow to pumped wells. The northeastern half of the study area lies in a recharge area and the southwestern half--which is nearer to the Raritan River--lies in a discharge area.

A digital model was developed to simulate both steady-state and transient ground-water flow and to analyze ground-water flow in the study area. The digital model used in this inves- 

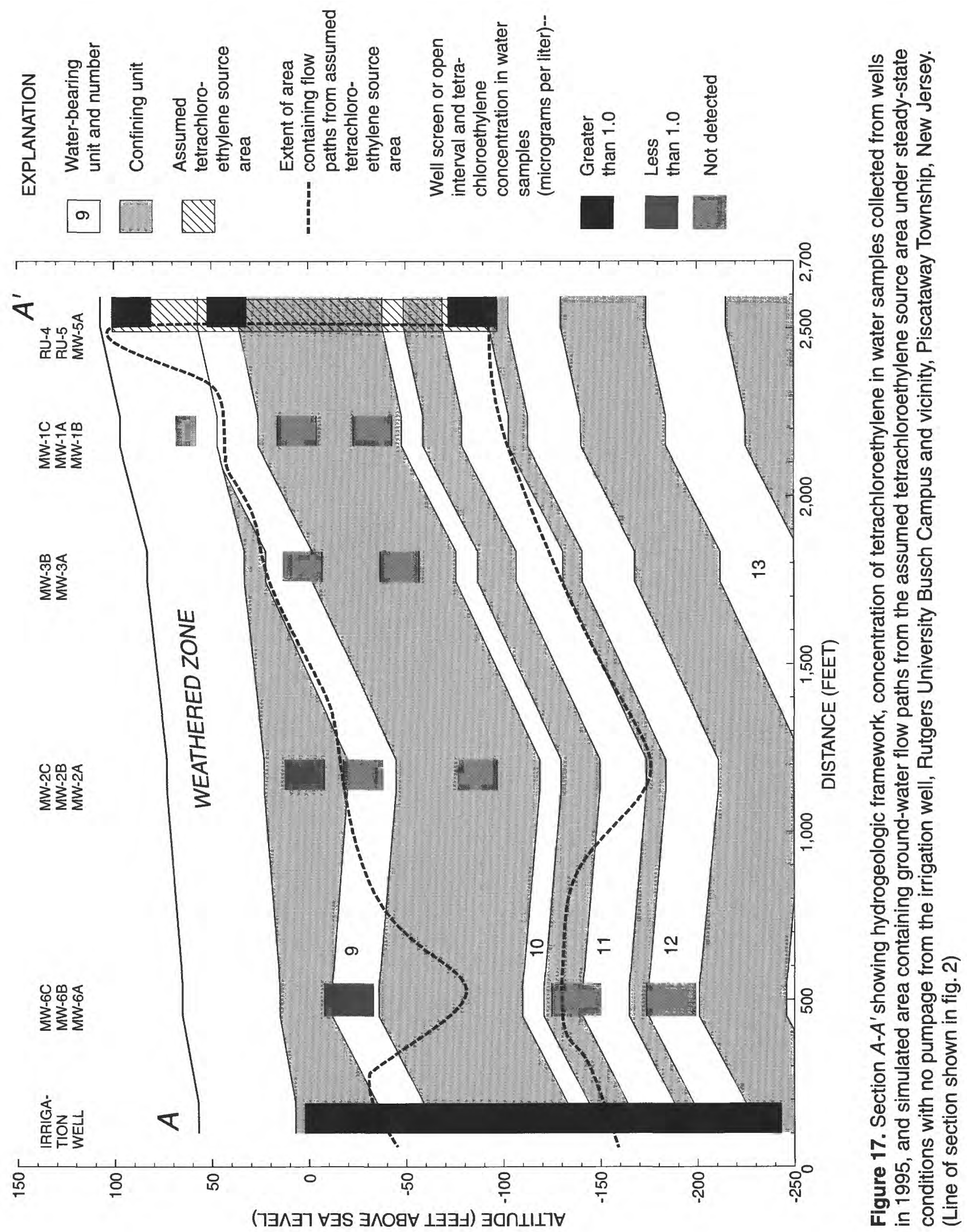


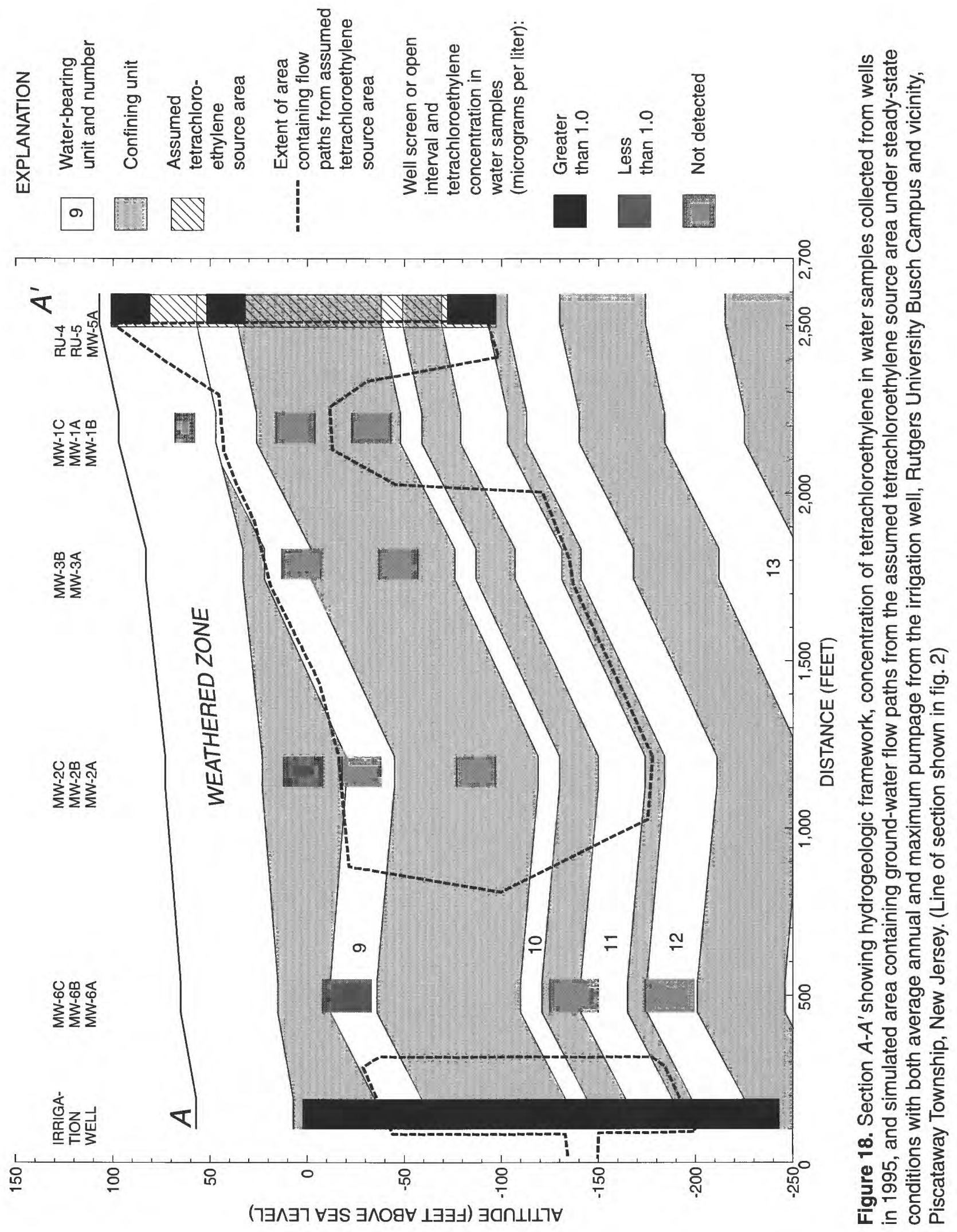


tigation simulates only advective transport of constituents dissolved in the water; dilution and dispersion of dissolved contaminants and the movement of dense nonaqueous-phase liquids cannot be simulated. The model area, which encompasses $2.3 \mathrm{mi}^{2}$, was extended beyond the study area to natural hydrologic boundaries.

Areal recharge was represented in the model as specified flux of 7.4 inches per year applied to the uppermost active model layer. Surface-water bodies were simulated as headdependent-flux boundaries. The value of vertical hydraulic conductivity of the streambed material used in the model is $1.0 \mathrm{ft} / \mathrm{d}$.

In the calibrated model, the horizontal transmissivity of the weathered zone is $16 \mathrm{ft}^{2} / \mathrm{d}$, and the transmissivity of the underlying waterbearing units ranges from 110 to $1,900 \mathrm{ft}^{2} / \mathrm{d}$ depending on lithology and depth. Vertical hydraulic conductivity in the calibrated model is $4.0 \times 10^{-3} \mathrm{ft} / \mathrm{d}$ in the weathered zone and ranges from $1.9 \times 10^{-8} \mathrm{ft} / \mathrm{d}$ to $7.7 \times 10^{-1} \mathrm{ft} / \mathrm{d}$ in the confining units, depending on lithology and depth. Below the weathered zone, both the transmissivity of the water-bearing units and the vertical hydraulic conductivity of the confining units decrease with depth. Storage coefficients are $3.0 \times 10^{-2}$ in the weathered zone and $4.0 \times 10^{-7}$ in all of the water-bearing units.

Water samples were collected from each of the 25 wells in the study area at least once during 1993-96. The spatial distributions of the two primary contaminants in the study area-carbon tetrachloride and PCE--differ from each other. The carbon tetrachloride plume, as defined by the points where this compound has been detected at concentrations exceeding the MCL, is localized in the C-Wing building area, although trace amounts were detected in wells as far as $750 \mathrm{ft}$ from the $\mathrm{C}$-Wing building. The plume's vertical extent is somewhere between 75 and $179 \mathrm{ft}$ below land surface.

The distribution of PCE, in contrast, is discontinuous. This compound was detected in concentrations above the New Jersey MCL of $1.0 \mu \mathrm{g} / \mathrm{L}$ at several locations in the study area. Concentrations were highest in shallow wells less than $10 \mathrm{ft}$ from the $\mathrm{C}$-Wing building. PCE was detected in samples from six additional wells in the study area. Of these six wells, the irrigation well, which is $2,370 \mathrm{ft}$ from the $\mathrm{C}$ Wing building, contained the highest concentration of PCE. PCE was not detected in samples from nine wells between the C-Wing building and the irrigation well, however.

The digital model was used to estimate the configuration of ground-water flow paths from the vicinity of the $\mathrm{C}$-Wing building. Actual flow paths through the fractured-rock aquifer system undoubtedly are more complex than the simulated paths. The simulated flow paths are primarily horizontal in the water-bearing units and vertical in the confining units. Horizontal flow generally is parallel or subparallel to the strike of the rock layers. When the irrigation well is not being pumped, all water that passes through the vicinity of the C-Wing building discharges to the Raritan River and its tributaries. It is unlikely that water reaching the stream from the $\mathrm{C}$-wing building still contains carbon tetrachloride because this compound has not been detected in concentrations above the MCL at distances greater than $10 \mathrm{ft}$ from the building.

Pumping at the irrigation well causes flow lines to shift toward the well. Analysis of flow paths shows that if this well were pumped continually at its current maximum short-term yield, all water that originates at or passes through the C-Wing building area would discharge to the irrigation well. The simulated flow paths do not reach any domestic well when the irrigation well is not pumped, and the distance between the flow paths and the nearest domestic well increases as simulated pumping from the irrigation well increases.

All wells in which carbon tetrachloride was detected are within the area encompassed by the flow paths from the assumed carbon tetrachloride source area, and the concentration of 
carbon tetrachloride decreases along flow paths. Therefore, the flow-path analysis supports the hypothesis that all of the carbon tetrachloride detected in the study area originated at the broken pipe near the $\mathrm{C}$-Wing building.

Some wells in which PCE was detected, however, are located outside the area encompassed by the flow paths from the assumed PCE source area. Consequently, both the simulated flow paths and the discontinuous distribution of PCE are inconsistent with the hypothesis that all of the PCE detected in the study area originated at the broken pipe near the $\mathrm{C}$-Wing building. Because of the complexity of actual ground-water flow paths through the fracturedrock aquifer system, however, it is not possible to state conclusively that an additional source of PCE must be present.

\section{REFERENCES CITED}

Aerial Data Reduction Associates, 1988, Topographic survey, Rutgers University, Middlesex County, N.J.: Pennsauken, New Jersey, Aerial Data Reduction Associates, scale 1:600.

Bouwer, H., and Rice, R.C., 1976, A slug test for determining hydraulic conductivity of unconfined aquifers with completely or partially penetrating wells: Water Resources Research, v. 12, no. 3, p. 423428.

Carleton, G.B., Welty, C., and Buxton, H.T., 1999, Design and analysis of tracer tests to determine effective porosity and dispersivity in fractured sedimentary rocks, Newark Basin, N.J.: U.S. Geological Survey Water-Resources Investigations Report 98-4126, $80 \mathrm{p}$.

Chichester, D.C., 1996, Hydrogeology of, and simulation of ground-water flow in, a mantled carbonate-rock system, Cumberland Valley, Pennsylvania: U.S. Geological Survey Water-Resources Investigations Report 94-4090, 39 p.
Cooper, H. H., Jr., Bredehoeft, J.D., and Papadopoulos, I.S., 1967, Response of a finite-diameter well to an instantaneous charge of water: Water Resources Research, v. 3, no. 1, p. 263-269.

dePaul, Vincent, 1996, Reconnaissance of volatile organic compounds in the subsurface at Rutgers University, Busch Campus, Piscataway Township, New Jersey: U.S. Geological Survey Open-File Report 95-729, 26 p.

ENSR Consulting and Engineering, 1989, Preliminary ground water assessment for the engineering building $\mathrm{C}$-wing basement, Piscataway, New Jersey: Somerset, New Jersey, ENSR Consulting and Engineering, 47 p., 4 app.

Freedman, D.L., and Gossett, J.M., 1989, Biological reductive dechlorination of tetrachloroethylene and trichloroethylene to ethylene under methanogenic conditions: Applied and Environmental Microbiology, v. 55, p. 2,144 to 2,151.

Froelich, A.J., and Olsen, P.E., 1985, Newark Supergroup, a revision of the Newark Group in eastern North America, in Robinson, G.R., and Froelich, A.J., eds, Proceedings of the second U.S. Geological Survey workshop on the Early Mesozoic basins of the eastern United States: U.S. Geological Survey Circular 946, p. 1-3.

Gerhart, J.M., and Lazorchick, G.J., 1988, Evaluation of the ground-water resources of the Lower Susquehanna River basin, Pennsylvania and Maryland: U.S. Geological Survey Water-Supply Paper 2284, $128 \mathrm{p}$.

Heath, R.C., 1983, Basic ground-water hydrology: U.S. Geological Survey WaterSupply Paper 2220, 84 p.

Houghton, H.F., 1990, Hydrogeology of the early Mesozoic rocks of the Newark Basin, New Jersey, in Kroll, R.L., and Brown, J.O, comp., Aspects of ground water in New Jersey: Seventh Annual Meeting of the Geological Association of New Jersey, October 26-27, 1990, Kean College, Union, N.J., p. E1-E36. 
Hvorslev, M.J., 1951, Time lag and soil permeability in ground water observations: U.S Army Corps of Engineers Waterway Experimentation Station, Vicksburg, Mississippi, Bulletin $36,56 \mathrm{p}$.

Keys, W.S., and MacCary, L.M., 1971, Application of borehole geophysics to water-resources investigations: U.S. Geological Survey Techniques of WaterResources Investigations, book 2, chap. E1, $126 \mathrm{p}$.

Keystone Aerial Surveys, Inc., 1985, Aerial photographs of Rutgers University: Philadelphia, Pennsylvania, Keystone Aerial Surveys, unpublished photographs.

Kueper, B.H., and McWhorter, D.B., 1991, The behavior of dense, nonaqueous phase liquids in fractured clay and rock: Ground Water, v. 29, no. 5, p 716-728.

Lewis-Brown, J.C., and Jacobsen, Eric, 1995, Hydrogeology and ground-water flow, fractured Mesozoic structural-basin rocks, Stony Brook, Beden Brook, and Jacobs Creek drainage basins, west-central New Jersey: U.S. Geological Survey WaterResources Investigations Report 94-4147, $83 \mathrm{p}$.

McDonald, M.G., and Harbaugh, A.W., 1988, A modular three-dimensional finitedifference ground-water flow model: U.S. Geological Survey Techniques of WaterResources Investigations, book 6, chap. A1, 576 p.

Michalski, Andrew. 1990, Hydrogeology of the Brunswick (Passaic) Formation and implications for ground water monitoring practice: Ground Water Monitoring Review, v. 10, no. 4, p 134-143.

New Jersey Administrative Code, 1990, Safe drinking-water act: Secondary Drinking Water Regulations, Title 7, Chapter 10, Subchapter 7, p. 10-19 to 10-21.
Olsen, P.E., 1980, Triassic and Jurassic Formations of the Newark Basin, in Field studies of New Jersey geology and guide to field trips, 52nd annual meeting of the New York State Geological Association, p. 2-39.

Pollack, D.W., 1994, User's guide for MODPATH/MODPATH-PLOT, Version 3: A particle tracking post-processing package for MODFLOW, the U.S. Geological Survey finite-difference ground-water flow model: U.S. Geological Survey Open-File Report 94-464, 104 p., 6 app.

Rantz, S. E., and others, 1982, Measurement and computation of streamflow--Volume 1. Measurement of stage and discharge; Volume 2. Computation of discharge: U.S. Geological Survey Water-Supply Paper 2175, $631 \mathrm{p}$.

Rima, D.R., Meisler, Harold, and Longwill, Stanley, 1962, Geology and hydrology of the Stockton Formation in southeastern Pennsylvania: A study of the effect of lithology upon the yield of wells: Pennsylvania Geological Survey, Fourth series, Bulletin W14, 46 p.

U.S. Environmental Protection Agency, 1991, Methods for the determination of organic compounds in drinking water: EPA 600/4-88/039.

1992, Methods for the determination of organic compounds in drinking water, Supplement II: EPA 600/R-92/129.

1994, Technical notes on drinking water methods: EPA 600/R-94/173.

Van Houten, F.B., 1969, Late Triassic Newark Group, north-central New Jersey and adjacent Pennsylvania and New York, in Subitzky, Seymour, ed., Geology of selected areas in New Jersey and Pennsylvania and guidebook of excursions: New Brunswick, N.J., Rutgers University Press, p. 314-347. 
Table 7. Concentrations of selected volatile organic compounds in, and chemical and physical properties of, water samples from wells, Rutgers University Busch Campus and vicinity, Piscataway Township, New Jersey, 1993-96

[All concentrations in micrograms per liter, unless otherwise noted; <, less than; B, compound present in method blank; $\mu \mathrm{S} / \mathrm{cm}$, microsiemens per centimeter at 25 degrees Celsius; deg C, degrees Celsius; $\mathrm{mg} / \mathrm{L}$, milligrams per liter; E, compound was positively detected but the amount detected is below where it can be reliably quantified; --, no data; all volatile organic compounds analyzed are listed in Appendix 2]

\begin{tabular}{|c|c|c|c|c|c|c|c|c|c|c|}
\hline $\begin{array}{c}\text { U.S. } \\
\text { Geological } \\
\text { Survey well } \\
\text { number } \\
\end{array}$ & Local well name & $\begin{array}{c}\text { Date } \\
\text { sampled }\end{array}$ & $\begin{array}{c}\text { Specitic } \\
\text { conduc- } \\
\text { tance } \\
(\mu \mathrm{S} / \mathrm{cm})\end{array}$ & $\begin{array}{c}\text { pH, field } \\
\text { (standard } \\
\text { units) }\end{array}$ & $\begin{array}{c}\text { Tempera- } \\
\text { ture, water } \\
\text { (deg C) }\end{array}$ & $\begin{array}{c}\text { Oxygen, dis- } \\
\text { solved } \\
\text { (mg/L) }\end{array}$ & Benzene & $\begin{array}{l}\text { Carbon tet- } \\
\text { rachloride }\end{array}$ & Chloroform & $\begin{array}{l}\text { cis-1,2- } \\
\text { Dichloro- } \\
\text { ethylene }\end{array}$ \\
\hline $23-1190$ & B-4 & $09-23-96$ & 727 & 6.76 & 21.1 & - & $<0.5$ & 100 & 4.6 & $<0.5$ \\
\hline $\begin{array}{l}23-1221 \\
23-1221 \\
23-1221 \\
23-1221 \\
23-1221\end{array}$ & $\mathrm{CH}-1 \mathrm{MW}$ & $\begin{array}{l}09-13-93 \\
07-14-94 \\
07-14-94 \\
09-28-95 \\
10-08-96\end{array}$ & $\begin{array}{r}5,390 \\
921 \\
921 \\
1,133 \\
1,504\end{array}$ & $\begin{array}{l}11.52 \\
11.88 \\
11.88 \\
11.64 \\
12.14\end{array}$ & $\begin{array}{l}15.0 \\
16.0 \\
16.0 \\
12.5 \\
12.8\end{array}$ & $\begin{array}{r}.8 \\
.2 \\
.2 \\
1.1 \\
--\end{array}$ & $\begin{array}{l}2.9 \\
<.5 \\
<.5 \\
<.5 \\
<.5\end{array}$ & $\begin{array}{l}<.5 \\
<.5 \\
<.5 \\
<.5 \\
<.5\end{array}$ & $\begin{array}{l}<.5 \\
<.5 \\
<.5 \\
<.5 \\
<.5\end{array}$ & $\begin{array}{l}\text { E .23 } \\
<.5 \\
<.5 \\
<.5 \\
<.5\end{array}$ \\
\hline $\begin{array}{l}23-1219 \\
23-1219 \\
23-1219 \\
23-1219 \\
23-1219\end{array}$ & CH-2MWA & $\begin{array}{l}08-24-93 \\
07-14-94 \\
09-26-95 \\
10-07-96 \\
10-07-96\end{array}$ & $\begin{array}{l}342 \\
324 \\
324 \\
328 \\
328\end{array}$ & $\begin{array}{l}7.12 \\
7.89 \\
7.85 \\
8.04 \\
8.04\end{array}$ & $\begin{array}{l}14.5 \\
13.0 \\
13.0 \\
13.0 \\
13.0\end{array}$ & $\begin{array}{l}6.3 \\
6.6 \\
6.0 \\
5.49 \\
5.49\end{array}$ & $\begin{array}{l}<.5 \\
<.5 \\
<.5 \\
<.5 \\
<.5\end{array}$ & $\begin{array}{l}<.5 \\
<.5 \\
<.5 \\
<.5 \\
<.5\end{array}$ & $\begin{array}{l}\quad .68 \\
<.5 \\
<.5 \\
<.5 \\
<.5\end{array}$ & $\begin{array}{l}<.5 \\
<.5 \\
<.5 \\
<.5 \\
<.5\end{array}$ \\
\hline $\begin{array}{l}23-1218 \\
23-1218 \\
23-1218 \\
23-1218\end{array}$ & CH-2MWB & $\begin{array}{l}08-23-93 \\
07-14-94 \\
09-26-95 \\
10-08-96\end{array}$ & $\begin{array}{l}423 \\
458 \\
586 \\
637\end{array}$ & $\begin{array}{l}7.17 \\
7.53 \\
7.34 \\
7.75\end{array}$ & $\begin{array}{l}14.5 \\
13.0 \\
12.5 \\
13.1\end{array}$ & $\begin{array}{l}6.0 \\
- \\
4.6 \\
5.31\end{array}$ & $\begin{array}{l}<.5 \\
<.5 \\
<.5 \\
<.5\end{array}$ & $\begin{array}{l}<.5 \\
<.5 \\
<.5 \\
<.5\end{array}$ & $\begin{aligned} & .50 \\
< & .5 \\
< & .5 \\
< & .5\end{aligned}$ & $\begin{array}{l}<.5 \\
<.5 \\
<.5 \\
<.5\end{array}$ \\
\hline $\begin{array}{l}23-1232 \\
23-1232 \\
23-1232 \\
23-1232 \\
23-1232\end{array}$ & $\mathrm{CH}-3 \mathrm{MW}$ & $\begin{array}{l}08-19-93 \\
08-19-93 \\
07-06-94 \\
09-22-95 \\
09-17-96\end{array}$ & $\begin{array}{l}510 \\
510 \\
525 \\
560 \\
553\end{array}$ & $\begin{array}{l}6.77 \\
6.77 \\
7.48 \\
7.51 \\
7.51\end{array}$ & $\begin{array}{l}17.0 \\
17.0 \\
16.5 \\
16.5 \\
17.0\end{array}$ & $\begin{array}{l}2.5 \\
2.5 \\
1.7 \\
1.4 \\
1.18\end{array}$ & $\begin{array}{l}<.5 \\
\mathrm{E} .14 \\
<.5 \\
<.5 \\
<.5\end{array}$ & $\begin{array}{l}<.5 \\
<.5 \\
<.5 \\
<.5 \\
<.5\end{array}$ & $\begin{array}{l}1.4 \\
1.4 \\
\text { E.44 } \\
<.5 \\
<.5\end{array}$ & $\begin{array}{l}<.5 \\
<.5 \\
<.5 \\
<.5 \\
<.5\end{array}$ \\
\hline $\begin{array}{l}23-1226 \\
23-1226 \\
23-1226 \\
23-1226\end{array}$ & $M W-1 A$ & $\begin{array}{l}09-14-93 \\
07-08-94 \\
09-19-95 \\
10-03-96\end{array}$ & $\begin{array}{l}276 \\
286 \\
276 \\
307\end{array}$ & $\begin{array}{l}7.66 \\
8.15 \\
8.16 \\
8.04\end{array}$ & $\begin{array}{l}14.5 \\
16.5 \\
16.0 \\
14.5\end{array}$ & $\begin{array}{l}1.1 \\
1.0 \\
1.7 \\
2.86\end{array}$ & $\begin{array}{l}<.5 \\
<.5 \\
<.5 \\
<.5\end{array}$ & $\begin{array}{l}\text { E } .29 \\
<.5 \\
1.2 \\
<.5\end{array}$ & $\begin{array}{l}\text { E } .05 \\
<.5 \\
<.5 \\
<.5\end{array}$ & $\begin{array}{l}<.5 \\
<.5 \\
<.5 \\
<.5\end{array}$ \\
\hline $\begin{array}{l}23-1227 \\
23-1227 \\
23-1227 \\
23-1227\end{array}$ & $M W-1 B$ & $\begin{array}{l}09-15-93 \\
07-06-94 \\
09-19-95 \\
10-04-96\end{array}$ & $\begin{array}{l}293 \\
288 \\
245 \\
283\end{array}$ & $\begin{array}{l}7.21 \\
8.64 \\
8.83 \\
8.31\end{array}$ & $\begin{array}{l}15.5 \\
14.0 \\
15.0 \\
14.3\end{array}$ & $\begin{array}{l}-- \\
<.1 \\
1.2 \\
3.00\end{array}$ & $\begin{array}{l}<.5 \\
<.5 \\
<.5 \\
<.5\end{array}$ & $\begin{array}{l}<.5 \\
<.5 \\
<.5 \\
<.5\end{array}$ & $\begin{array}{l}<.5 \\
<.5 \\
<.5 \\
<.5\end{array}$ & $\begin{array}{l}<.5 \\
<.5 \\
<.5 \\
<.5\end{array}$ \\
\hline $\begin{array}{l}23-1228 \\
23-1228 \\
23-1228 \\
23-1228\end{array}$ & $M W-1 C$ & $\begin{array}{l}08-23-93 \\
07-06-94 \\
11-21-95 \\
10-04-96\end{array}$ & $\begin{array}{l}459 \\
513 \\
517 \\
537\end{array}$ & $\begin{array}{l}6.99 \\
7.43 \\
7.35 \\
7.38\end{array}$ & $\begin{array}{l}16.5 \\
16.5 \\
14.5 \\
14.3\end{array}$ & $\begin{array}{l}- \\
2.8 \\
.9 \\
2.70\end{array}$ & $\begin{array}{l}<.5 \\
<.5 \\
<.5 \\
<.5\end{array}$ & $\begin{array}{l}<.5 \\
<.5 \\
<.5 \\
<.5\end{array}$ & $\begin{array}{l}\text { E } .07 \\
\text { E.066 } \\
<.5 \\
<.5\end{array}$ & $\begin{array}{l}<.5 \\
<.5 \\
<.5 \\
<.5\end{array}$ \\
\hline $\begin{array}{l}23-1223 \\
23-1223 \\
23-1223 \\
23-1223\end{array}$ & $M W-2 A$ & $\begin{array}{l}08-17-93 \\
07-08-94 \\
09-20-95 \\
09-26-96\end{array}$ & $\begin{array}{l}745 \\
270 \\
443 \\
409\end{array}$ & $\begin{array}{l}7.26 \\
8.85 \\
8.10 \\
8.05\end{array}$ & $\begin{array}{l}15.5 \\
16.5 \\
16.0 \\
17.0\end{array}$ & $\begin{array}{c}1.9 \\
<.1 \\
.2 \\
.90\end{array}$ & $\begin{array}{l}<.5 \\
<.5 \\
<.5 \\
<.5\end{array}$ & $\begin{array}{l}<.5 \\
<.5 \\
<.5 \\
<.5\end{array}$ & $\begin{array}{l}<.5 \\
<.5 \\
<.5 \\
<.5\end{array}$ & $\begin{array}{l}<.5 \\
<.5 \\
<.5 \\
<.5\end{array}$ \\
\hline $\begin{array}{l}23-1224 \\
23-1224 \\
23-1224 \\
23-1224\end{array}$ & $M W-2 B$ & $\begin{array}{c}08-18-93 \\
07-08-94 \\
09-20-95 \\
10-02-96\end{array}$ & $\begin{array}{l}411 \\
433 \\
457 \\
454\end{array}$ & $\begin{array}{l}6.91 \\
7.84 \\
6.46 \\
7.92\end{array}$ & $\begin{array}{l}14.0 \\
13.5 \\
13.0 \\
13.0\end{array}$ & $\begin{array}{r}1.2 \\
.5 \\
.5 \\
.6\end{array}$ & $\begin{array}{l}<.5 \\
<.5 \\
<.5 \\
<.5\end{array}$ & $\begin{array}{l}\text { E } .17 \\
<.5 \\
<.5 \\
<.5\end{array}$ & $\begin{array}{l}\text { E .25 } \\
<.5 \\
<.5 \\
<.5\end{array}$ & $\begin{array}{l}<.5 \\
<.5 \\
<.5 \\
<.5\end{array}$ \\
\hline $\begin{array}{l}23-1225 \\
23-1225 \\
23-1225 \\
23-1225\end{array}$ & MW-2C & $\begin{array}{l}08-18-93 \\
07-08-94 \\
09-25-95 \\
09-26-96\end{array}$ & $\begin{array}{l}425 \\
574 \\
491 \\
535\end{array}$ & $\begin{array}{l}6.26 \\
7.11 \\
6.63 \\
6.76\end{array}$ & $\begin{array}{l}14.5 \\
15.0 \\
14.0 \\
14.5\end{array}$ & $\begin{array}{l}- \\
1.6 \\
2.3 \\
1.36\end{array}$ & $\begin{array}{l}\text { E } .07 \\
<.5 \\
<.5 \\
<.5\end{array}$ & $\begin{array}{l}\text { E } .08 \\
<.5 \\
<.5 \\
<.5\end{array}$ & $\begin{array}{l}\text { E .42 } \\
<.5 \\
<.5 \\
<.5\end{array}$ & $\begin{array}{l}<.5 \\
<.5 \\
<.5 \\
<.5\end{array}$ \\
\hline $\begin{array}{l}23-1229 \\
23-1229 \\
23-1229 \\
23-1229 \\
23-1229\end{array}$ & MW-3A & $\begin{array}{l}08-25-93 \\
08-25-93 \\
07-12-94 \\
09-21-95 \\
10-01-96\end{array}$ & $\begin{array}{l}315 \\
315 \\
331 \\
290 \\
296\end{array}$ & $\begin{array}{l}7.24 \\
7.24 \\
7.88 \\
8.15 \\
8.12\end{array}$ & $\begin{array}{l}15.0 \\
15.0 \\
14.0 \\
14.0 \\
13.8\end{array}$ & $\begin{array}{c}2.1 \\
2.1 \\
.5 \\
.3 \\
.55\end{array}$ & $\begin{array}{l}<.5 \\
<.5 \\
<.5 \\
<.5 \\
<.5\end{array}$ & $\begin{array}{l}\text { E } .05 \\
\text { E.06 } \\
<.5 \\
<.5 \\
<.5\end{array}$ & $\begin{array}{l}<.5 \\
<.5 \\
<.5 \\
<.5 \\
<.5\end{array}$ & $\begin{array}{l}<.5 \\
<.5 \\
<.5 \\
<.5 \\
<.5\end{array}$ \\
\hline 23-1230 & MW-3B & $09-13-93$ & 411 & 6.90 & 14.5 & -- & E.26 & .80 & E .21 & $<.5$ \\
\hline $\begin{array}{l}23-1230 \\
23-1230 \\
23-1229\end{array}$ & & $\begin{array}{l}07-12-94 \\
09-26-95 \\
10-02-96\end{array}$ & $\begin{array}{l}450 \\
451 \\
481\end{array}$ & $\begin{array}{l}7.74 \\
7.69 \\
7.79\end{array}$ & $\begin{array}{l}13.5 \\
13.5 \\
13.3\end{array}$ & $\begin{array}{l}1.9 \\
2.0 \\
2.39\end{array}$ & $\begin{array}{l}<.5 \\
<.5 \\
<.5\end{array}$ & $\begin{array}{l}.57 \\
.8 \\
.8\end{array}$ & $\begin{array}{l}<.5 \\
0.5 \\
<.5\end{array}$ & $\begin{array}{l}<.5 \\
<.5 \\
<.5\end{array}$ \\
\hline $\begin{array}{l}23-1231 \\
23-1231 \\
23-1231\end{array}$ & $M W-4$ & $\begin{array}{l}01-19-95 \\
11-08-95 \\
09-24-96\end{array}$ & $\begin{array}{l}240 \\
247 \\
230\end{array}$ & $\begin{array}{l}9.16 \\
9.26 \\
9.53\end{array}$ & $\begin{array}{l}16.5 \\
17.5 \\
17.0\end{array}$ & $\begin{array}{l}- \\
--\end{array}$ & $\begin{array}{l}<.5 \\
<.5 \\
<.5\end{array}$ & $\begin{array}{l}<.5 \\
<.5 \\
<.5\end{array}$ & $\begin{array}{l}<.5 \\
<.5 \\
<.5\end{array}$ & $\begin{array}{l}<.5 \\
<.5 \\
<.5\end{array}$ \\
\hline
\end{tabular}


Table 7. Concentrations of selected volatile organic compounds in, and chemical and physical properties of, water samples from wells, Rutgers University Busch Campus and vicinity, Piscataway Township, New Jersey, 1993-96 -Continued

[All concentrations in micrograms per liter, unless otherwise noted; <, less than; B, compound present in method blank; $\mu \mathrm{S} / \mathrm{cm}$, microsiemens per centimeter at 25 degrees Celsius; $\operatorname{deg} \mathrm{C}$, degrees Celsius; $\mathrm{mg} / \mathrm{L}$, milligrams per liter; $\mathrm{E}$, compound was positively detected but the amount detected is below where it can be reliably quantified; --, no data; all volatile organic compounds analyzed are listed in Appendix 2]

\begin{tabular}{|c|c|c|c|c|c|c|c|c|c|c|}
\hline $\begin{array}{c}\text { U.S. } \\
\text { Geological } \\
\text { Survey well } \\
\text { number } \\
\end{array}$ & Local well name & $\begin{array}{c}\text { Date } \\
\text { sampled }\end{array}$ & $\begin{array}{l}\text { Specific } \\
\text { conduc- } \\
\text { tance } \\
(\mu S / \mathrm{cm})\end{array}$ & $\begin{array}{c}\text { pH, field } \\
\text { (standard } \\
\text { units) }\end{array}$ & $\begin{array}{c}\text { Tempera- } \\
\text { ture, water } \\
\text { (deg C) }\end{array}$ & $\begin{array}{c}\text { Oxygen, dis- } \\
\text { solved } \\
\text { (mg/L) }\end{array}$ & Benzene & $\begin{array}{l}\text { Carbon tet- } \\
\text { rachloride }\end{array}$ & Chloroform & $\begin{array}{l}\text { cis-1,2- } \\
\text { Dichloro- } \\
\text { ethylene }\end{array}$ \\
\hline $\begin{array}{l}23-1268 \\
23-1268 \\
23-1268\end{array}$ & $M W-5 A$ & $\begin{array}{l}11-28-95 \\
10-09-96 \\
10-09-96\end{array}$ & $\begin{array}{l}347 \\
381 \\
381\end{array}$ & $\begin{array}{l}7.97 \\
7.95 \\
7.95\end{array}$ & $\begin{array}{l}14.0 \\
14.6 \\
14.6\end{array}$ & $\begin{array}{l}2.4 \\
2.07 \\
2.07\end{array}$ & $\begin{array}{l}<.5 \\
<.5 \\
<.5\end{array}$ & $\begin{array}{l}<.5 \\
<.5 \\
<.5\end{array}$ & $\begin{array}{l}<.5 \\
<.5 \\
<.5\end{array}$ & $\begin{array}{l}1.3 \\
1.6 \\
1.5\end{array}$ \\
\hline $\begin{array}{l}23-1265 \\
23-1265\end{array}$ & $M W-6 A$ & $\begin{array}{l}11-22-95 \\
09-25-96\end{array}$ & $\begin{array}{l}1,373 \\
1,414\end{array}$ & $\begin{array}{l}7.45 \\
7.48\end{array}$ & $\begin{array}{l}13.5 \\
13.2\end{array}$ & $\begin{array}{c}<.1 \\
.03\end{array}$ & $\begin{array}{l}<.5 \\
<.5\end{array}$ & $\begin{array}{l}<.5 \\
<.5\end{array}$ & $\begin{array}{l}<.5 \\
<.5\end{array}$ & $\begin{array}{l}<.5 \\
<.5\end{array}$ \\
\hline $\begin{array}{l}23-1266 \\
23-1266\end{array}$ & $M W-6 B$ & $\begin{array}{l}11-21-95 \\
09-24-96\end{array}$ & $\begin{array}{l}597 \\
507\end{array}$ & $\begin{array}{l}7.64 \\
7.70\end{array}$ & $\begin{array}{l}13.0 \\
13.2\end{array}$ & $\begin{array}{c}<.1 \\
.09\end{array}$ & $\begin{array}{l}<.5 \\
<.5\end{array}$ & $\begin{array}{l}<.5 \\
<.5\end{array}$ & $\begin{array}{l}<.5 \\
<.5\end{array}$ & $\begin{array}{l}<.5 \\
<.5\end{array}$ \\
\hline $\begin{array}{l}23-1267 \\
23-1267 \\
23-1267\end{array}$ & $M W-6 C$ & $\begin{array}{l}11-22-95 \\
09-24-96 \\
09-24-96\end{array}$ & $\begin{array}{l}429 \\
449 \\
449\end{array}$ & $\begin{array}{l}7.32 \\
7.29 \\
7.30\end{array}$ & $\begin{array}{l}12.5 \\
12.7 \\
12.7\end{array}$ & $\begin{array}{l}2.7 \\
2.11 \\
2.11\end{array}$ & $\begin{array}{l}<.5 \\
<.5 \\
<.5\end{array}$ & $\begin{array}{l}<.5 \\
<.5 \\
<.5\end{array}$ & $\begin{array}{l}<.5 \\
<.5 \\
<.5\end{array}$ & $\begin{array}{l}<.5 \\
<.5 \\
<.5\end{array}$ \\
\hline $\begin{array}{l}23-1263 \\
23-1263 \\
23-1263\end{array}$ & MW-7A & $\begin{array}{l}11-08-95 \\
11-08-95 \\
09-18-96\end{array}$ & $\begin{array}{l}427 \\
427 \\
490\end{array}$ & $\begin{array}{l}7.92 \\
7.92 \\
7.92\end{array}$ & $\begin{array}{l}12.5 \\
12.5 \\
12.9\end{array}$ & $\begin{array}{l}2.5 \\
2.5 \\
3.46\end{array}$ & $\begin{array}{l}<.5 \\
<.5 \\
<.5\end{array}$ & $\begin{array}{l}<.5 \\
<.5 \\
<.5\end{array}$ & $\begin{array}{r}.5 \\
<.5 \\
.6\end{array}$ & $\begin{array}{l}<.5 \\
<.5 \\
<.5\end{array}$ \\
\hline $\begin{array}{l}23-1264 \\
23-1264\end{array}$ & MW-7B & $\begin{array}{l}11-08-95 \\
09-18-96\end{array}$ & $\begin{array}{l}644 \\
574\end{array}$ & $\begin{array}{l}7.94 \\
7.73\end{array}$ & $\begin{array}{l}13.0 \\
13.3\end{array}$ & $\begin{array}{l}2.4 \\
1.28\end{array}$ & $\begin{array}{l}<.5 \\
<.5\end{array}$ & $\begin{array}{l}<.5 \\
<.5\end{array}$ & $\begin{array}{l}<.5 \\
<.5\end{array}$ & $\begin{array}{l}<.5 \\
<.5\end{array}$ \\
\hline $\begin{array}{l}23-1184 \\
23-1184 \\
23-1184 \\
23-1184 \\
23-1184\end{array}$ & RU-2 & $\begin{array}{l}08-20-93 \\
07-15-94 \\
11-28-95 \\
10-09-96 \\
10-09-96\end{array}$ & $\begin{array}{r}954 \\
1,034 \\
569 \\
462 \\
462\end{array}$ & $\begin{array}{l}6.47 \\
7.39 \\
7.29 \\
7.10 \\
7.10\end{array}$ & $\begin{array}{l}24.5 \\
20.5 \\
19.0 \\
21.0 \\
21.0\end{array}$ & $\begin{array}{l}1.4 \\
6.3 \\
5.57 \\
5.57\end{array}$ & $\begin{array}{l}<.5 \\
<.5 \\
<50 \\
<.5 \\
<.5\end{array}$ & $\begin{array}{r}150 \\
6,600 \\
2,100 \\
300 \\
230\end{array}$ & $\begin{array}{r}14 \\
110 \\
<50 \\
12 \\
10\end{array}$ & $\begin{array}{l}<.5 \\
<.5 \\
<50 \\
<.5 \\
<.5\end{array}$ \\
\hline $\begin{array}{l}23-1185 \\
23-1185 \\
23-1185 \\
23-1185\end{array}$ & $\mathrm{RU}-4$ & $\begin{array}{l}07-15-94 \\
11-28-95 \\
11-28-95 \\
10-10-96\end{array}$ & $\begin{array}{l}524 \\
268 \\
268 \\
630\end{array}$ & $\begin{array}{l}6.87 \\
6.60 \\
6.60 \\
6.85\end{array}$ & $\begin{array}{l}18.0 \\
18.5 \\
18.5 \\
18.4\end{array}$ & $\begin{array}{l}1.6 \\
- \\
\overline{5} .96\end{array}$ & $\begin{aligned} & 3.40 \\
< & 250 \\
< & 250 \\
< & 25\end{aligned}$ & $\begin{array}{l}24,000 \\
21,000 \\
18,000 \\
25,000\end{array}$ & $\begin{array}{r}50 \\
<250 \\
<250 \\
35\end{array}$ & $\begin{aligned} & 5.20 \\
< & 250 \\
< & 250 \\
< & 25\end{aligned}$ \\
\hline $\begin{array}{l}23-1183 \\
23-1183 \\
23-1183 \\
23-1183\end{array}$ & RU-5 & $\begin{array}{l}07-15-94 \\
11-29-95 \\
10-10-96 \\
10-10-96\end{array}$ & $\begin{array}{l}364 \\
374 \\
395 \\
395\end{array}$ & $\begin{array}{l}7.46 \\
7.75 \\
7.85 \\
7.85\end{array}$ & $\begin{array}{l}18.0 \\
16.0 \\
17.5 \\
17.5\end{array}$ & $\begin{array}{l}6.3 \\
6.6 \\
5.40 \\
5.40\end{array}$ & $\begin{array}{l}<.5 \\
<50 \\
<25 \\
<25\end{array}$ & $\begin{array}{l}6,000 \\
8,500 \\
6,400 \\
5,600\end{array}$ & $\begin{array}{r}25 \\
<50 \\
<25 \\
28\end{array}$ & $\begin{array}{l}<.5 \\
<50 \\
<25 \\
<25\end{array}$ \\
\hline $\begin{array}{l}23-1165 \\
23-1165 \\
23-1165 \\
23-1165 \\
23-1165\end{array}$ & Rutgers golf 13 obs & $\begin{array}{l}08-24-93 \\
07-12-94 \\
09-28-95 \\
09-28-95 \\
09-19-96\end{array}$ & $\begin{array}{l}954 \\
832 \\
859 \\
859 \\
786\end{array}$ & $\begin{array}{l}6.84 \\
7.63 \\
7.59 \\
7.59 \\
7.40\end{array}$ & $\begin{array}{l}14.0 \\
13.0 \\
13.0 \\
13.0 \\
13.0\end{array}$ & $\begin{array}{r}.4 \\
.5 \\
.2 \\
.2 \\
<.1\end{array}$ & $\begin{array}{l}<.5 \\
<.5 \\
<.5 \\
<.5 \\
<.5\end{array}$ & $\begin{array}{l}<.5 \\
<.5 \\
<.5 \\
<.5 \\
<.5\end{array}$ & $\begin{array}{l}E .13 \\
<.5 \\
<.5 \\
<.5 \\
<.5\end{array}$ & $\begin{array}{l}<.5 \\
<.5 \\
<.5 \\
<.5 \\
<.5\end{array}$ \\
\hline 23-1053 & $\begin{array}{l}\text { Rutgers golf course } \\
\text { (Irrigation well) }\end{array}$ & $08-17-93$ & 2,170 & 6.42 & 14.0 & 0.5 & $<0.5$ & $<0.5$ & $<0.5$ & $<0.5$ \\
\hline $\begin{array}{l}23-1053 \\
23-1053 \\
23-1053 \\
23-1053\end{array}$ & & $\begin{array}{l}06-01-94 \\
09-19-95 \\
09-25-96 \\
09-25-96\end{array}$ & $\begin{array}{l}2,080 \\
2,330 \\
2,120 \\
2,120\end{array}$ & $\begin{array}{l}7.49 \\
7.41 \\
7.43 \\
7.43\end{array}$ & $\begin{array}{l}16.0 \\
13.5 \\
13.4 \\
13.4\end{array}$ & $\begin{array}{l}<.1 \\
0.1 \\
<.1\end{array}$ & $\begin{array}{l}<.5 \\
<.5 \\
<.5 \\
<.5\end{array}$ & $\begin{array}{l}<.5 \\
<.5 \\
<.5 \\
<.5\end{array}$ & $\begin{array}{l}<.5 \\
<.5 \\
<.5 \\
<.5\end{array}$ & $\begin{array}{l}<.5 \\
\text { E. } .19 \\
<.5 \\
<.5\end{array}$ \\
\hline
\end{tabular}


Table 7. Concentrations of selected volatile organic compounds in, and chemical and physical properties of, water samples from wells, Rutgers University Busch Campus and vicinity, Piscataway Township, New Jersey, 1993-96-Continued

\begin{tabular}{|c|c|c|c|c|c|c|c|c|c|}
\hline $\begin{array}{c}\text { U.S. } \\
\text { Geological } \\
\text { Survey wel } \\
\text { number } \\
\end{array}$ & Local well name & $\begin{array}{c}\text { Date } \\
\text { sampled }\end{array}$ & $\begin{array}{c}1,2 \\
\text { Dichloro- } \\
\text { ethane }\end{array}$ & $\begin{array}{l}\text { Hexachlor- } \\
\text { obutadiene }\end{array}$ & $\begin{array}{c}\text { Methylene } \\
\text { chloride }\end{array}$ & $\begin{array}{c}\text { Tetrachloro- } \\
\text { ethylene }\end{array}$ & Toluene & $\begin{array}{l}\text { Trichloro- } \\
\text { ethylene }\end{array}$ & $\begin{array}{c}\text { Trichloro- } \\
\text { fluoro- } \\
\text { methane }\end{array}$ \\
\hline $23-1190$ & B-4 & 09-23-96 & $<0.5$ & $<0.5$ & $<0.5$ & 1.7 & $<0.5$ & $<0.5$ & $<0.5$ \\
\hline $\begin{array}{l}23-1221 \\
23-1221 \\
23-1221 \\
23-1221 \\
23-1221\end{array}$ & $\mathrm{CH}-1 \mathrm{MW}$ & $\begin{array}{l}09-13-93 \\
07-14-94 \\
07-14-94 \\
09-28-95 \\
10-08-96\end{array}$ & $\begin{array}{l}<.5 \\
<.5 \\
<.5 \\
<.5 \\
<.5\end{array}$ & $\begin{array}{l}<.5 \\
<.5 \\
<.5 \\
<.5 \\
<.5\end{array}$ & $\begin{array}{l}<.5 \\
2.3 \mathrm{~B} \\
2.2 \mathrm{~B} \\
<.5 \\
1.2 \mathrm{~B}\end{array}$ & $\begin{array}{l}<.5 \\
<.5 \\
<.5 \\
<.5 \\
<.5\end{array}$ & $\begin{array}{l}1.5 \\
<.5 \\
<.5 \\
<.5 \\
<.5\end{array}$ & $\begin{array}{l}1.1 \\
<.5 \\
<.5 \\
<.5 \\
<.5\end{array}$ & $\begin{array}{l}<.5 \\
<.5 \\
<.5 \\
<.5 \\
<.5\end{array}$ \\
\hline $\begin{array}{l}23-1219 \\
23-1219 \\
23-1219 \\
23-1219 \\
23-1219\end{array}$ & CH-2MWA & $\begin{array}{l}08-24-93 \\
07-14-94 \\
09-26-95 \\
10-07-96 \\
10-07-96\end{array}$ & $\begin{array}{l}<.5 \\
<.5 \\
<.5 \\
<.5 \\
<.5\end{array}$ & $\begin{array}{l}<.5 \\
<.5 \\
<.5 \\
<.5 \\
<.5\end{array}$ & $\begin{array}{l}2.74 \mathrm{~B} \\
2.4 \mathrm{~B} \\
<.5 \\
1.2 \mathrm{~B} \\
1.3 \mathrm{~B}\end{array}$ & $\begin{array}{l}\text { E. } .21 \\
<.5 \\
<.5 \\
<.5 \\
<.5\end{array}$ & $\begin{array}{l}E .22 \\
<.5 \\
<.5 \\
<.5 \\
<.5\end{array}$ & $\begin{array}{l}<.5 \\
<.5 \\
<.5 \\
<.5 \\
<.5\end{array}$ & $\begin{array}{l}<.5 \\
<.5 \\
<.5 \\
<.5 \\
<.5\end{array}$ \\
\hline $\begin{array}{l}23-1218 \\
23-1218 \\
23-1218 \\
23-1218\end{array}$ & $\mathrm{CH}-2 \mathrm{MWB}$ & $\begin{array}{l}08-23-93 \\
07-14-94 \\
09-26-95 \\
10-08-96\end{array}$ & $\begin{array}{l}<.5 \\
<.5 \\
<.5 \\
<.5\end{array}$ & $\begin{array}{l}<.5 \\
<.5 \\
<.5 \\
<.5\end{array}$ & $\begin{array}{l}0.8 \\
2.1 \mathrm{~B} \\
<.5 \\
2.1 \mathrm{~B}\end{array}$ & $\begin{array}{l}3.7 \\
1.7 \\
4.2 \\
1.4\end{array}$ & $\begin{array}{l}<.5 \\
<.5 \\
<.5 \\
<.5\end{array}$ & $\begin{array}{l}<.5 \\
<.5 \\
<.5 \\
<.5\end{array}$ & $\begin{array}{l}<.5 \\
<.5 \\
<.5 \\
<.5\end{array}$ \\
\hline $\begin{array}{l}23-1232 \\
23-1232 \\
23-1232 \\
23-1232 \\
23-1232\end{array}$ & CH-3MW & $\begin{array}{l}08-19-93 \\
08-19-93 \\
07-06-94 \\
09-22-95 \\
09-17-96\end{array}$ & $\begin{array}{l}<.5 \\
<.5 \\
<.5 \\
<.5 \\
<.5\end{array}$ & $\begin{array}{l}<.5 \\
<.5 \\
<.5 \\
<.5 \\
<.5\end{array}$ & $\begin{array}{l}\text { E. } .23 \\
\text { E.24 } \\
\text { E.37 } \\
<.5 \\
<.5\end{array}$ & $\begin{array}{l}<.5 \\
E .16 \\
<.5 \\
<.5 \\
<.5\end{array}$ & $\begin{array}{l}\text { E. } .30 \\
\text { E.29 } \\
<.5 \\
<.5 \\
<.5\end{array}$ & $\begin{array}{l}<.5 \\
<.5 \\
<.5 \\
<.5 \\
<.5\end{array}$ & $\begin{array}{l}<.5 \\
<.5 \\
<.5 \\
<.5 \\
<.5\end{array}$ \\
\hline $\begin{array}{l}23-1226 \\
23-1226 \\
23-1226 \\
23-1226\end{array}$ & $M W-1 A$ & $\begin{array}{l}09-14-93 \\
07-08-94 \\
09-19-95 \\
10-03-96\end{array}$ & $\begin{array}{l}<.5 \\
<.5 \\
<.5 \\
<.5\end{array}$ & $\begin{array}{l}<.5 \\
<.5 \\
<.5 \\
<.5\end{array}$ & $\begin{array}{l}<.5 \\
<.5 \\
<.5 \\
6.1 \mathrm{~B}\end{array}$ & $\begin{array}{l}<.5 \\
<.5 \\
<.5 \\
<.5\end{array}$ & $\begin{array}{l}<.5 \\
<.5 \\
<.5 \\
<.5\end{array}$ & $\begin{array}{l}<.5 \\
<.5 \\
<.5 \\
<.5\end{array}$ & $\begin{array}{l}<.5 \\
<.5 \\
<.5 \\
<.5\end{array}$ \\
\hline $\begin{array}{l}23-1227 \\
23-1227 \\
23-1227 \\
23-1227\end{array}$ & $M W-1 B$ & $\begin{array}{l}09-15-93 \\
07-06-94 \\
09-19-95 \\
10-04-96\end{array}$ & $\begin{array}{l}<.5 \\
<.5 \\
<.5 \\
<.5\end{array}$ & $\begin{array}{l}<.5 \\
<.5 \\
<.5 \\
<.5\end{array}$ & $\begin{array}{l}<.5 \\
\text { E } .36 \\
<.5 \\
1.3\end{array}$ & $\begin{array}{l}<.5 \\
<.5 \\
<.5 \\
<.5\end{array}$ & $\begin{array}{l}\text { E } .09 \\
<.5 \\
<.5 \\
<.5\end{array}$ & $\begin{array}{l}<.5 \\
<.5 \\
<.5 \\
<.5\end{array}$ & $\begin{array}{l}<.5 \\
<.5 \\
<.5 \\
<.5\end{array}$ \\
\hline $\begin{array}{l}23-1228 \\
23-1228 \\
23-1228 \\
23-1228\end{array}$ & $M W-1 C$ & $\begin{array}{c}08-23-93 \\
07-06-94 \\
11-21-95 \\
10-04-96\end{array}$ & $\begin{array}{l}<.5 \\
<.5 \\
<.5 \\
<.5\end{array}$ & $\begin{array}{l}<.5 \\
<.5 \\
<.5 \\
<.5\end{array}$ & $\begin{array}{l}<.5 \\
<.5 \\
<.5 \\
1.3\end{array}$ & $\begin{array}{l}<.5 \\
<.5 \\
<.5 \\
<.5\end{array}$ & $\begin{array}{l}<.5 \\
<.5 \\
<.5 \\
<.5\end{array}$ & $\begin{array}{l}<.5 \\
<.5 \\
<.5 \\
<.5\end{array}$ & $\begin{array}{l}<.5 \\
<.5 \\
<.5 \\
<.5\end{array}$ \\
\hline $\begin{array}{l}23-1223 \\
23-1223 \\
23-1223 \\
23-1223\end{array}$ & $M W-2 A$ & $\begin{array}{l}08-17-93 \\
07-08-94 \\
09-20-95 \\
09-26-96\end{array}$ & $\begin{array}{l}<.5 \\
<.5 \\
<.5 \\
<.5\end{array}$ & $\begin{array}{l}<.5 \\
<.5 \\
<.5 \\
<.5\end{array}$ & $\begin{array}{l}\text { E. } .24 \\
<.5 \\
<.5 \\
2.1\end{array}$ & $\begin{array}{l}<.5 \\
<.5 \\
<.5 \\
<.5\end{array}$ & $\begin{array}{l}\text { E } .20 \\
<.5 \\
<.5 \\
<.5\end{array}$ & $\begin{array}{l}<.5 \\
<.5 \\
<.5 \\
<.5\end{array}$ & $\begin{array}{l}<.5 \\
<.5 \\
<.5 \\
<.5\end{array}$ \\
\hline $\begin{array}{l}23-1224 \\
23-1224 \\
23-1224 \\
23-1224\end{array}$ & MW-2B & $\begin{array}{c}08-18-93 \\
07-08-94 \\
09-20-95 \\
10-02-96\end{array}$ & $\begin{array}{l}<.5 \\
<.5 \\
<.5 \\
<.5\end{array}$ & $\begin{array}{l}<.5 \\
<.5 \\
<.5 \\
<.5\end{array}$ & $\begin{array}{l}<.5 \\
<.5 \\
<.5 \\
3.7\end{array}$ & $\begin{array}{l}\text { E } .44 \\
<.5 \\
<.5 \\
<.5\end{array}$ & $\begin{array}{l}<.5 \\
<.5 \\
<.5 \\
<.5\end{array}$ & $\begin{array}{l}<.5 \\
<.5 \\
<.5 \\
<.5\end{array}$ & $\begin{array}{l}<.5 \\
<.5 \\
<.5 \\
<.5\end{array}$ \\
\hline $\begin{array}{l}23-1225 \\
23-1225 \\
23-1225 \\
23-1225\end{array}$ & $M W-2 C$ & $\begin{array}{l}08-18-93 \\
07-08-94 \\
09-26-95 \\
09-26-96\end{array}$ & $\begin{array}{l}<.5 \\
<.5 \\
<.5 \\
<.5\end{array}$ & $\begin{array}{l}<.5 \\
<.5 \\
<.5 \\
<.5\end{array}$ & $\begin{array}{l}<.5 \\
<.5 \\
<.5 \\
3.8\end{array}$ & $\begin{array}{l}1.0 \\
.74 \\
.8 \\
.6\end{array}$ & $\begin{array}{l}<.5 \\
<.5 \\
<.5 \\
<.5\end{array}$ & $\begin{array}{l}<.5 \\
<.5 \\
<.5 \\
<.5\end{array}$ & $\begin{array}{l}<.5 \\
<.5 \\
<.5 \\
<.5\end{array}$ \\
\hline $\begin{array}{l}23-1229 \\
23-1229 \\
23-1229 \\
23-1229 \\
23-1229\end{array}$ & $M W-3 A$ & $\begin{array}{l}08-25-93 \\
08-25-93 \\
07-12-94 \\
09-21-95 \\
10-01-96\end{array}$ & $\begin{array}{l}<.5 \\
<.5 \\
<.5 \\
<.5 \\
<.5\end{array}$ & $\begin{array}{l}<.5 \\
<.5 \\
<.5 \\
<.5 \\
<.5\end{array}$ & $\begin{array}{r}.85 \mathrm{~B} \\
.82 \mathrm{~B} \\
.53 \mathrm{~B} \\
<.5 \\
.5\end{array}$ & $\begin{array}{l}<.5 \\
<.5 \\
<.5 \\
<.5 \\
<.5\end{array}$ & $\begin{array}{l}<.5 \\
<.5 \\
<.5 \\
<.5 \\
<.5\end{array}$ & $\begin{array}{l}<.5 \\
<.5 \\
<.5 \\
<.5 \\
<.5\end{array}$ & $\begin{array}{l}<.5 \\
<.5 \\
<.5 \\
<.5 \\
<.5\end{array}$ \\
\hline $\begin{array}{l}23-1230 \\
23-1230 \\
23-1230 \\
23-1229\end{array}$ & MW-3B & $\begin{array}{l}09-13-93 \\
07-12-94 \\
09-26-95 \\
10-02-96\end{array}$ & $\begin{array}{l}<.5 \\
<.5 \\
<.5 \\
<.5\end{array}$ & $\begin{array}{l}<.5 \\
<.5 \\
<.5 \\
<.5\end{array}$ & $\begin{array}{l}<.5 \\
.57 \mathrm{~B} \\
<.5 \\
<.5\end{array}$ & $\begin{array}{l}<.5 \\
<.5 \\
<.5 \\
<.5\end{array}$ & $\begin{array}{l}\text { E } .06 \\
<.5 \\
<.5 \\
<.5\end{array}$ & $\begin{array}{l}<.5 \\
<.5 \\
<.5 \\
<.5\end{array}$ & $\begin{array}{l}<.5 \\
<.5 \\
<.5 \\
<.5\end{array}$ \\
\hline $\begin{array}{l}23-1231 \\
23-1231 \\
23-1231\end{array}$ & $M W-4$ & $\begin{array}{l}01-19-95 \\
11-08-95 \\
09-24-96\end{array}$ & $\begin{array}{l}<.5 \\
<.5 \\
<.5\end{array}$ & $\begin{array}{l}<.5 \\
<.5 \\
<.5\end{array}$ & $\begin{array}{l}<.5 \\
<.5 \\
<.5\end{array}$ & $\begin{array}{l}<.5 \\
<.5 \\
<.5\end{array}$ & $\begin{array}{l}<.5 \\
<.5 \\
<.5\end{array}$ & $\begin{array}{l}<.5 \\
<.5 \\
<.5\end{array}$ & $\begin{array}{l}<.5 \\
<.5 \\
<.5\end{array}$ \\
\hline
\end{tabular}


Table 7. Concentrations of selected volatile organic compounds in, and chemical and physical properties of, water samples from wells, Rutgers University Busch Campus and vicinity, Piscataway Township, New Jersey, 1993-96-Continued

\begin{tabular}{|c|c|c|c|c|c|c|c|c|c|}
\hline $\begin{array}{c}\text { U.S. } \\
\text { Geological } \\
\text { Survey well } \\
\text { number }\end{array}$ & Local well name & $\begin{array}{c}\text { Date } \\
\text { sampled }\end{array}$ & $\begin{array}{c}1,2 \\
\text { Dichloro- } \\
\text { ethane }\end{array}$ & $\begin{array}{l}\text { Hexachlor- } \\
\text { obutadiene }\end{array}$ & $\begin{array}{l}\text { Methylene } \\
\text { chloride }\end{array}$ & $\begin{array}{l}\text { Tetrachloro- } \\
\text { ethylene }\end{array}$ & Toluene & $\begin{array}{l}\text { Trichloro- } \\
\text { ethylene }\end{array}$ & $\begin{array}{c}\text { Trichloro- } \\
\text { fluoro- } \\
\text { methane }\end{array}$ \\
\hline $\begin{array}{l}23-1268 \\
23-1268 \\
23-1268\end{array}$ & MW-5A & $\begin{array}{l}11-28-95 \\
10-09-96 \\
10-09-96\end{array}$ & $\begin{array}{l}<.5 \\
<.5 \\
<.5\end{array}$ & $\begin{array}{l}<.5 \\
<.5 \\
<.5\end{array}$ & $\begin{array}{l}<.5 \\
1.9 \\
2.2\end{array}$ & $\begin{array}{r}1.4 \\
1.0 \\
.9\end{array}$ & $\begin{array}{l}<.5 \\
<.5 \\
<.5\end{array}$ & $\begin{array}{l}1.6 \\
1.3 \\
1.5\end{array}$ & $\begin{array}{l}<.5 \\
<.5 \\
<.5\end{array}$ \\
\hline $\begin{array}{l}\text { 23-1265 } \\
23-1265\end{array}$ & MW-6A & $\begin{array}{l}11-22-95 \\
09-25-96\end{array}$ & $\begin{array}{l}<.5 \\
<.5\end{array}$ & $\begin{array}{l}<.5 \\
<.5\end{array}$ & $\begin{array}{l}<.5 \\
1.6\end{array}$ & $\begin{array}{r}<.5 \\
.5\end{array}$ & $\begin{array}{r}0.8 \\
<.5\end{array}$ & $\begin{array}{l}<.5 \\
<.5\end{array}$ & $\begin{array}{l}<.5 \\
<.5\end{array}$ \\
\hline $\begin{array}{l}23-1266 \\
23-1266\end{array}$ & $M W-6 B$ & $\begin{array}{l}11-21-95 \\
09-24-96\end{array}$ & $\begin{array}{l}<.5 \\
<.5\end{array}$ & $\begin{array}{l}<.5 \\
<.5\end{array}$ & $\begin{array}{l}<.5 \\
1.5\end{array}$ & $\begin{array}{l}<.5 \\
<.5\end{array}$ & $\begin{array}{l}<.5 \\
<.5\end{array}$ & $\begin{array}{l}<.5 \\
<.5\end{array}$ & $\begin{array}{l}<.5 \\
<.5\end{array}$ \\
\hline $\begin{array}{l}23-1267 \\
23-1267 \\
23-1267\end{array}$ & $M W-6 C$ & $\begin{array}{l}11-22-95 \\
09-24-96 \\
09-24-96\end{array}$ & $\begin{array}{l}<.5 \\
<.5 \\
<.5\end{array}$ & $\begin{array}{l}<.5 \\
<.5 \\
<.5\end{array}$ & $\begin{array}{l}<.5 \\
<.5 \\
<.5\end{array}$ & $\begin{array}{r}\quad .5 \\
<.5 \\
<.5\end{array}$ & $\begin{array}{l}<.5 \\
<.5 \\
<.5\end{array}$ & $\begin{array}{l}<.5 \\
<.5 \\
<.5\end{array}$ & $\begin{array}{l}<.5 \\
<.5 \\
<.5\end{array}$ \\
\hline $\begin{array}{l}23-1263 \\
23-1263 \\
23-1263\end{array}$ & MW-7A & $\begin{array}{l}11-08-95 \\
11-08-95 \\
09-18-96\end{array}$ & $\begin{array}{l}<.5 \\
<.5 \\
<.5\end{array}$ & $\begin{array}{l}<.5 \\
<.5 \\
<.5\end{array}$ & $\begin{array}{l}<.5 \\
<.5 \\
<.5\end{array}$ & $\begin{array}{l}<.5 \\
<.5 \\
<.5\end{array}$ & $\begin{array}{l}<.5 \\
<.5 \\
<.5\end{array}$ & $\begin{array}{l}<.5 \\
<.5 \\
<.5\end{array}$ & $\begin{array}{l}<.5 \\
<.5 \\
<.5\end{array}$ \\
\hline $\begin{array}{l}23-1264 \\
23-1264\end{array}$ & MW-7B & $\begin{array}{l}11-08-95 \\
09-18-96\end{array}$ & $\begin{array}{l}<.5 \\
<.5\end{array}$ & $\begin{array}{l}<.5 \\
<.5\end{array}$ & $\begin{array}{l}<.5 \\
<.5\end{array}$ & $\begin{array}{l}<.5 \\
<.5\end{array}$ & $\begin{array}{l}29 \\
<.5\end{array}$ & $\begin{array}{l}<.5 \\
<.5\end{array}$ & $\begin{array}{l}<.5 \\
<.5\end{array}$ \\
\hline $\begin{array}{l}23-1184 \\
23-1184 \\
23-1184 \\
23-1184 \\
23-1184\end{array}$ & RU-2 & $\begin{array}{l}08-20-93 \\
07-15-94 \\
11-28-95 \\
10-09-96 \\
10-09-96\end{array}$ & $\begin{aligned}<.5 \\
<.5 \\
<50 \\
<.5 \\
<.5\end{aligned}$ & $\begin{array}{r}<.5 \\
3.7 \\
<50 \\
<.5 \\
<.5\end{array}$ & $\begin{array}{c}\text { E.16 } \\
3.0 \mathrm{~B} \\
<50 \\
2.2 \\
4.4\end{array}$ & $\begin{array}{c}5.1 \\
34 \\
<50 \\
5.1 \\
4.4\end{array}$ & $\begin{aligned}<.5 \\
<.5 \\
<50 \\
<.5 \\
<.5\end{aligned}$ & $\begin{aligned}<.5 \\
<.5 \\
<50 \\
<.5 \\
<.5\end{aligned}$ & $\begin{aligned} & E .15 \\
&<.5 \\
&<50 \\
&<.5 \\
&<.5\end{aligned}$ \\
\hline $\begin{array}{l}23-1185 \\
23-1185 \\
23-1185 \\
23-1185\end{array}$ & RU-4 & $\begin{array}{l}07-15-94 \\
11-28-95 \\
11-28-95 \\
10-10-96\end{array}$ & $\begin{array}{r}36 \\
<250 \\
<250 \\
<25\end{array}$ & $\begin{array}{l}<250^{.95} \\
<250 \\
<25\end{array}$ & $\begin{aligned} & 1.3 B \\
&< 250 \\
&< 250 \\
& 100\end{aligned}$ & $\begin{array}{r}1,000 \\
1,300 \\
990 \\
1,200\end{array}$ & $\begin{aligned} & 2.0 \\
&< 250 \\
&<250 \\
&<25\end{aligned}$ & $\begin{array}{r}9 \\
<250 \\
<250 \\
<25\end{array}$ & $\begin{array}{l}<250 \\
<28 \\
<250 \\
<25\end{array}$ \\
\hline $\begin{array}{l}23-1183 \\
23-1183 \\
23-1183 \\
23-1183\end{array}$ & RU-5 & $\begin{array}{l}07-15-94 \\
11-29-95 \\
10-10-96 \\
10-10-96\end{array}$ & $\begin{array}{l}<.5 \\
<50 \\
<25 \\
<25\end{array}$ & $\begin{array}{l}<.5 \\
<50 \\
<25 \\
<25\end{array}$ & $\begin{array}{c}2.4 \mathrm{~B} \\
<50 \\
94 \\
89\end{array}$ & $\begin{array}{r}100 \\
130 \\
96 \\
99\end{array}$ & $\begin{array}{l}<.5 \\
<50 \\
<25 \\
<25\end{array}$ & $\begin{array}{l}\quad 0.81 \\
<50 \\
<25 \\
<25\end{array}$ & $\begin{aligned} & 1.6 \\
< & 50 \\
< & 25 \\
< & 25\end{aligned}$ \\
\hline $\begin{array}{l}23-1165 \\
23-1165 \\
23-1165 \\
23-1165 \\
23-1165\end{array}$ & Rutgers golf 13 obs & $\begin{array}{l}08-24-93 \\
07-12-94 \\
09-28-95 \\
09-28-95 \\
09-19-96\end{array}$ & $\begin{array}{l}<.5 \\
<.5 \\
<.5 \\
<.5 \\
<.5\end{array}$ & $\begin{array}{l}<.5 \\
<.5 \\
<.5 \\
<.5 \\
<.5\end{array}$ & $\begin{array}{l}1.0 \mathrm{~B} \\
<.5 \\
<.5 \\
<.5 \\
1.2\end{array}$ & $\begin{array}{l}1.7 \\
.86 \\
1.7 \\
1.6 \\
<.5\end{array}$ & $\begin{array}{l}<.5 \\
<.5 \\
<.5 \\
<.5 \\
<.5\end{array}$ & $\begin{array}{l}<.5 \\
<.5 \\
<.5 \\
<.5 \\
<.5\end{array}$ & $\begin{array}{l}<.5 \\
<.5 \\
<.5 \\
<.5 \\
<.5\end{array}$ \\
\hline $23-1053$ & $\begin{array}{l}\text { Rutgers golf course } \\
\text { (Irrigation well) }\end{array}$ & 08-17-93 & $<0.5$ & $<0.5$ & $<0.5$ & 21 & $<0.5$ & $<0.5$ & $<0.5$ \\
\hline $\begin{array}{l}23-1053 \\
23-1053 \\
23-1053 \\
23-1053\end{array}$ & & $\begin{array}{l}06-01-94 \\
09-19-95 \\
09-25-96 \\
09-25-96\end{array}$ & $\begin{array}{l}<.5 \\
<.5 \\
<.5 \\
<.5\end{array}$ & $\begin{array}{l}<.5 \\
<.5 \\
<.5 \\
<.5\end{array}$ & $\begin{array}{l}<.5 \\
<.5 \\
.8 \\
2.1\end{array}$ & $\begin{array}{l}16 \\
23 \\
26 \\
26\end{array}$ & $\begin{array}{l}<.5 \\
<.5 \\
<.5 \\
<.5\end{array}$ & $\begin{array}{l}\text { E } .13 \\
<.5 \\
<.5 \\
<.5\end{array}$ & $\begin{array}{l}<.5 \\
<.5 \\
<.5 \\
<.5\end{array}$ \\
\hline
\end{tabular}


Appendix 1. Water-level altitudes in wells, Rutgers University Busch campus and vicinity, Piscataway Township, New Jersey, 1992-96

\begin{tabular}{|c|c|c|c|c|c|c|}
\hline $\begin{array}{c}\text { U.S. } \\
\text { Geologi- } \\
\text { cal } \\
\text { Survey } \\
\text { well } \\
\text { number }\end{array}$ & $\begin{array}{l}\text { Local } \\
\text { well } \\
\text { name }\end{array}$ & $\begin{array}{c}\text { Depth of } \\
\text { screened } \\
\text { or open } \\
\text { interval } \\
\text { (feet below } \\
\text { land } \\
\text { surface) }\end{array}$ & $\begin{array}{l}\text { Altitude } \\
\text { of land } \\
\text { surface } \\
\text { (feet } \\
\text { above sea } \\
\text { level) }\end{array}$ & $\begin{array}{l}\text { Date } \\
\text { measured } \\
\text { (YYMMDD) }\end{array}$ & $\begin{array}{l}\text { Water- } \\
\text { level } \\
\text { altitude } \\
\text { (feet } \\
\text { above sea } \\
\text { level) }\end{array}$ & Remarks \\
\hline \multirow[t]{2}{*}{$23-1191$} & B-1 & $14-15$ & 79.47 & $\begin{array}{l}920113 \\
920404 \\
921123 \\
951019 \\
961028\end{array}$ & $\begin{array}{l}75.62 \\
75.73 \\
75.55 \\
75.23 \\
75.64\end{array}$ & \\
\hline & & & & 961029 & 75.49 & \\
\hline \multirow[t]{4}{*}{$23-1190$} & B-4 & $2-4$ & 96.14 & $\begin{array}{l}920113 \\
920404 \\
921123 \\
930930 \\
931103\end{array}$ & $\begin{array}{l}96.12 \\
95.96 \\
95.93 \\
95.93 \\
95.82\end{array}$ & \\
\hline & & & & $\begin{array}{l}931202 \\
940207 \\
940324 \\
940426 \\
940601\end{array}$ & $\begin{array}{l}95.98 \\
95.42 \\
95.91 \\
94.82 \\
94.40\end{array}$ & Ice melt may cause non-static conditions \\
\hline & & & & $\begin{array}{l}940630 \\
940801 \\
940913 \\
951019 \\
961028\end{array}$ & $\begin{array}{l}96.25 \\
94.95 \\
94.71 \\
95.49 \\
95.54\end{array}$ & $2 n$ rain previous night \\
\hline & & & & 961029 & 95.49 & \\
\hline \multirow[t]{3}{*}{ 23-1187 } & B-6 & $14-16$ & 84.01 & $\begin{array}{l}921123 \\
930930 \\
931103 \\
931202 \\
940207\end{array}$ & $\begin{array}{l}76.40 \\
79.17 \\
80.01 \\
78.88 \\
76.79\end{array}$ & \\
\hline & & & & $\begin{array}{l}940324 \\
940427 \\
940601 \\
940630 \\
940801\end{array}$ & $\begin{array}{l}79.99 \\
79.24 \\
78.07 \\
76.80 \\
78.40\end{array}$ & $\begin{array}{l}\text { Ice melt may cause non-static conditions } \\
\text { 2" rain previous night }\end{array}$ \\
\hline & & & & $\begin{array}{l}940913 \\
951019 \\
961028 \\
961029\end{array}$ & $\begin{array}{l}76.20 \\
78.17 \\
79.92 \\
79.59\end{array}$ & \\
\hline \multirow[t]{3}{*}{ 23-1221 } & $\mathrm{CH}-1 \mathrm{MW}$ & $30-40$ & 99.75 & $\begin{array}{l}930913 \\
930930 \\
931103 \\
931202 \\
940207\end{array}$ & $\begin{array}{l}79.46 \\
83.28 \\
85.53 \\
84.28 \\
86.24\end{array}$ & \\
\hline & & & & $\begin{array}{l}940324 \\
940426 \\
940601 \\
940630 \\
940801\end{array}$ & $\begin{array}{l}97.40 \\
87.86 \\
84.94 \\
80.16 \\
82.20\end{array}$ & Ice melt may cause non-static conditions \\
\hline & & & & 940913 & 80.48 & \\
\hline
\end{tabular}


Appendix 1. Water-level altitudes in wells, Rutgers University Busch campus and vicinity, Piscataway Township, New Jersey, 1992-96 --Continued

$[<$, less than; $>$, greater than]

\begin{tabular}{|c|c|c|c|c|c|c|}
\hline $\begin{array}{l}\text { U.S. } \\
\text { Geologi- } \\
\text { cal } \\
\text { Survey } \\
\text { well } \\
\text { number }\end{array}$ & $\begin{array}{l}\text { Local } \\
\text { well } \\
\text { name }\end{array}$ & $\begin{array}{c}\text { Depth of } \\
\text { screened } \\
\text { or open } \\
\text { interval } \\
\text { (feet below } \\
\text { land } \\
\text { surface) }\end{array}$ & $\begin{array}{l}\text { Altitude } \\
\text { of land } \\
\text { surface } \\
\text { (feet } \\
\text { above sea } \\
\text { level) }\end{array}$ & $\begin{array}{c}\text { Date } \\
\text { measured } \\
\text { (YYMMDD) }\end{array}$ & $\begin{array}{l}\text { Water- } \\
\text { level } \\
\text { altitude } \\
\text { (feet } \\
\text { above sea } \\
\text { level) }\end{array}$ & Remarks \\
\hline & & & & $\begin{array}{l}951019 \\
961028 \\
961029\end{array}$ & $\begin{array}{l}82.62 \\
86.58 \\
86.52\end{array}$ & \\
\hline 23-1219 & CH-2MWA & $70-90$ & 91.03 & $\begin{array}{l}930824 \\
930930 \\
931103 \\
931202 \\
940207\end{array}$ & $\begin{array}{l}65.42 \\
68.69 \\
71.24 \\
71.52 \\
70.43\end{array}$ & \\
\hline & & & & $\begin{array}{l}940324 \\
940426 \\
940601 \\
940630 \\
940801\end{array}$ & $\begin{array}{l}72.56 \\
73.19 \\
65.07 \\
62.38 \\
68.35\end{array}$ & $\begin{array}{l}\text { Ice melt may cause non-static conditions } \\
2 \text { " rain previous night }\end{array}$ \\
\hline & & & & $\begin{array}{l}940913 \\
951019 \\
961028 \\
961029\end{array}$ & $\begin{array}{l}69.79 \\
68.14 \\
72.12 \\
64.12\end{array}$ & \\
\hline $23-1218$ & CH-2MWB & $30-40$ & 91.31 & $\begin{array}{l}930823 \\
930930 \\
931103 \\
931202 \\
940207\end{array}$ & $\begin{array}{l}80.73 \\
83.16 \\
84.27 \\
84.15 \\
83.88\end{array}$ & \\
\hline & & & & $\begin{array}{l}940324 \\
940426 \\
940601 \\
940630 \\
940801 \\
\\
940913 \\
951019 \\
961028 \\
961029\end{array}$ & $\begin{array}{l}86.72 \\
84.73 \\
83.42 \\
83.13 \\
83.47 \\
\\
82.30 \\
83.75 \\
84.89 \\
84.33\end{array}$ & $\begin{array}{l}\text { Ice melt may cause non-static conditions } \\
\text { 2" rain previous night }\end{array}$ \\
\hline $23-1232$ & $\mathrm{CH}-3 \mathrm{MW}$ & $140-160$ & 103.98 & $\begin{array}{l}930819 \\
930930 \\
931103 \\
931202 \\
940207\end{array}$ & $\begin{array}{l}63.56 \\
68.78 \\
71.21 \\
71.50 \\
70.39\end{array}$ & \\
\hline & & & & $\begin{array}{l}940324 \\
940426 \\
940601 \\
940630 \\
940801\end{array}$ & $\begin{array}{l}72.52 \\
72.24 \\
64.73 \\
62.84 \\
68.50\end{array}$ & $\begin{array}{l}\text { Ice melt may cause non-static conditions } \\
2 \text { " rain previous night }\end{array}$ \\
\hline & & & & $\begin{array}{l}940913 \\
951019 \\
961028 \\
961029\end{array}$ & $\begin{array}{l}65.24 \\
68.32 \\
71.97 \\
62.30\end{array}$ & \\
\hline $23-1226$ & $M W-1 A$ & $80-100$ & 96.29 & $\begin{array}{l}930914 \\
930930 \\
931103\end{array}$ & $\begin{array}{l}65.10 \\
68.86 \\
71.31\end{array}$ & \\
\hline
\end{tabular}


Appendix 1. Water-level altitudes in wells, Rutgers University Busch campus and vicinity, Piscataway Township, New Jersey, 1992-96 --Continued

$[<$, less than; >, greater than]

\begin{tabular}{|c|c|c|c|c|c|c|}
\hline $\begin{array}{l}\text { U.S. } \\
\text { Geologi- } \\
\text { cal } \\
\text { Survey } \\
\text { well } \\
\text { number }\end{array}$ & $\begin{array}{c}\text { Local } \\
\text { well } \\
\text { name }\end{array}$ & $\begin{array}{l}\text { Depth of } \\
\text { screened } \\
\text { or open } \\
\text { interval } \\
\text { (feet below } \\
\text { land } \\
\text { surface) }\end{array}$ & $\begin{array}{l}\text { Altitude } \\
\text { of land } \\
\text { surface } \\
\text { (feet } \\
\text { above sea } \\
\text { level) }\end{array}$ & $\begin{array}{l}\text { Date } \\
\text { measured } \\
\text { (YYMMDD) }\end{array}$ & $\begin{array}{c}\text { Water- } \\
\text { level } \\
\text { altitude } \\
\text { (feet } \\
\text { above sea } \\
\text { level) }\end{array}$ & Remarks \\
\hline & & & & 931202 & 71.62 & \\
\hline & & & & 940207 & 70.64 & \\
\hline & & & & 940324 & 72.70 & Ice melt may cause non-static conditions \\
\hline & & & & 940426 & 73.28 & \\
\hline & & & & 940601 & 66.82 & \\
\hline & & & & 940630 & 62.36 & 2 " rain previous night \\
\hline & & & & 940801 & 68.44 & \\
\hline & & & & 940913 & 64.95 & \\
\hline & & & & 951019 & 68.26 & \\
\hline & & & & 961028 & 72.12 & \\
\hline & & & & 961029 & 64.42 & \\
\hline \multirow[t]{14}{*}{ 23-1227 } & $M W-1 B$ & $120-140$ & 97.00 & 930915 & 65.44 & \\
\hline & & & & 930930 & 68.65 & \\
\hline & & & & 931103 & 71.09 & \\
\hline & & & & 931202 & 71.34 & \\
\hline & & & & 940207 & 70.43 & \\
\hline & & & & 940324 & 72.54 & Ice melt may cause non-static conditions \\
\hline & & & & 940426 & 73.62 & \\
\hline & & & & 940601 & 68.36 & \\
\hline & & & & 940630 & 65.60 & $2^{\prime \prime}$ rain previous night \\
\hline & & & & 940801 & 68.22 & \\
\hline & & & & 940913 & 64.56 & \\
\hline & & & & 951019 & $68.11 \mid$ & \\
\hline & & & & 961028 & 71.83 & \\
\hline & & & & 961029 & 67.64 & \\
\hline \multirow[t]{14}{*}{ 23-1228 } & $M W-1 C$ & $30-40$ & 97.82 & 930823 & 71.23 & \\
\hline & & & & 930930 & 74.40 & \\
\hline & & & & 931103 & 76.69 & \\
\hline & & & & 931202 & 77.06 & \\
\hline & & & & 940207 & 76.65 & \\
\hline & & & & 940324 & 78.54 & Ice melt may cause non-static conditions \\
\hline & & & & 940426 & 78.84 & \\
\hline & & & & 940601 & 74.97 & \\
\hline & & & & 940630 & 70.09 & $2 "$ rain previous night \\
\hline & & & & 940801 & 74.53 & \\
\hline & & & & 940913 & 71.50 & \\
\hline & & & & 951019 & 74.08 & \\
\hline & & & & 961028 & 77.69 & \\
\hline & & & & 961029 & 75.73 & \\
\hline \multirow[t]{9}{*}{$23-1223$} & MW-2A & $150-170$ & 72.80 & 930817 & 49.03 & \\
\hline & & & & 930930 & 57.63 & \\
\hline & & & & 931103 & 58.79 & \\
\hline & & & & 931202 & 58.53 & \\
\hline & & & & 940324 & 66.95 & Ice melt may cause non-static conditions \\
\hline & & & & 940426 & 61.21 & \\
\hline & & & & 940601 & 57.69 & May not be static--nearby irrigation well recently pumped \\
\hline & & & & 940630 & 65.67 & $2 "$ rain previous night \\
\hline & & & & 940801 & 56.39 & \\
\hline
\end{tabular}


Appendix 1. Water-level altitudes in wells, Rutgers University Busch campus and vicinity, Piscataway Township, New Jersey, 1992-96 --Continued

[<, less than; >, greater than]

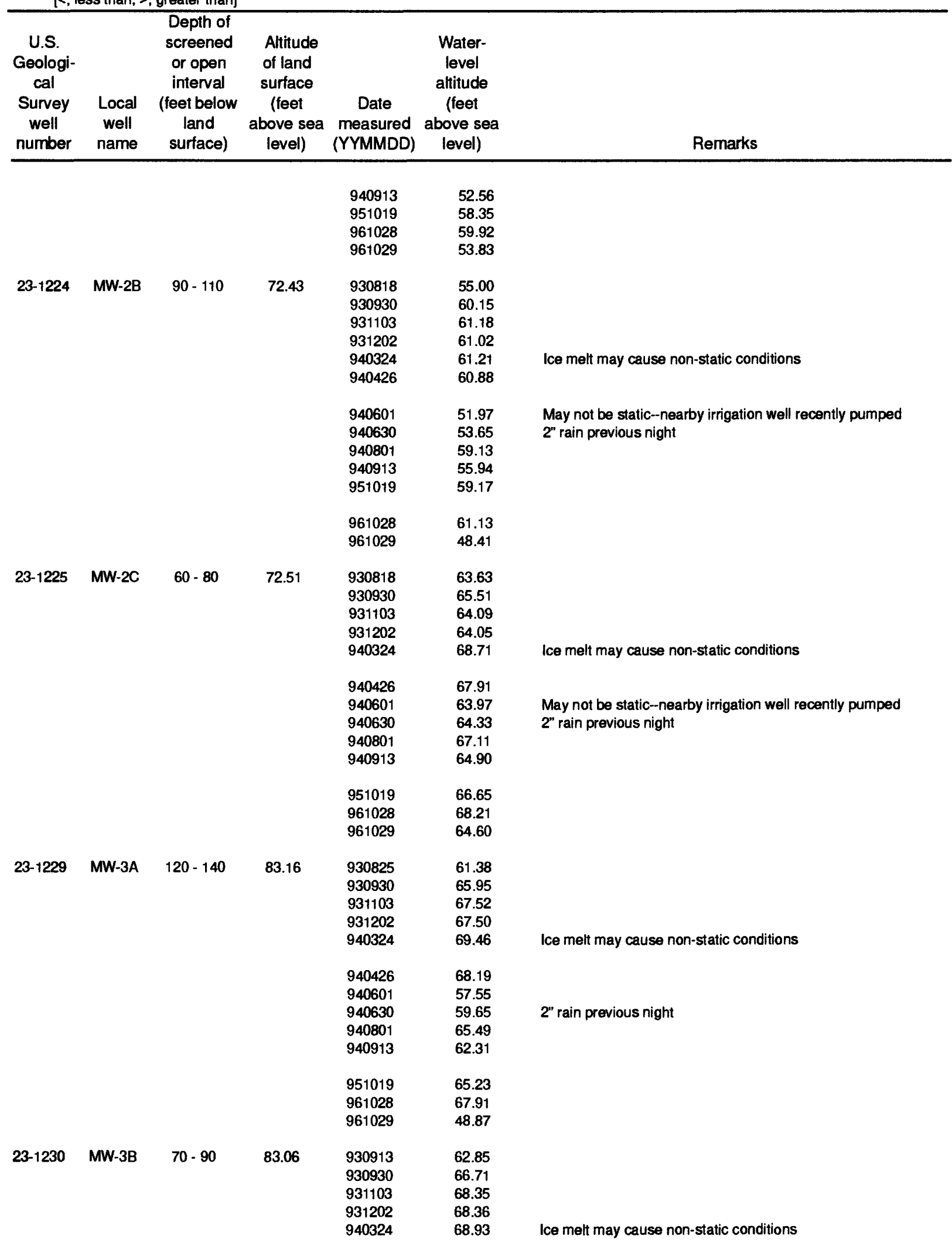


Appendix 1. Water-level altitudes in wells, Rutgers University Busch campus and vicinity, Piscataway Township, New Jersey, 1992-96 --Continued

$[<$, less than; $>$, greater than]

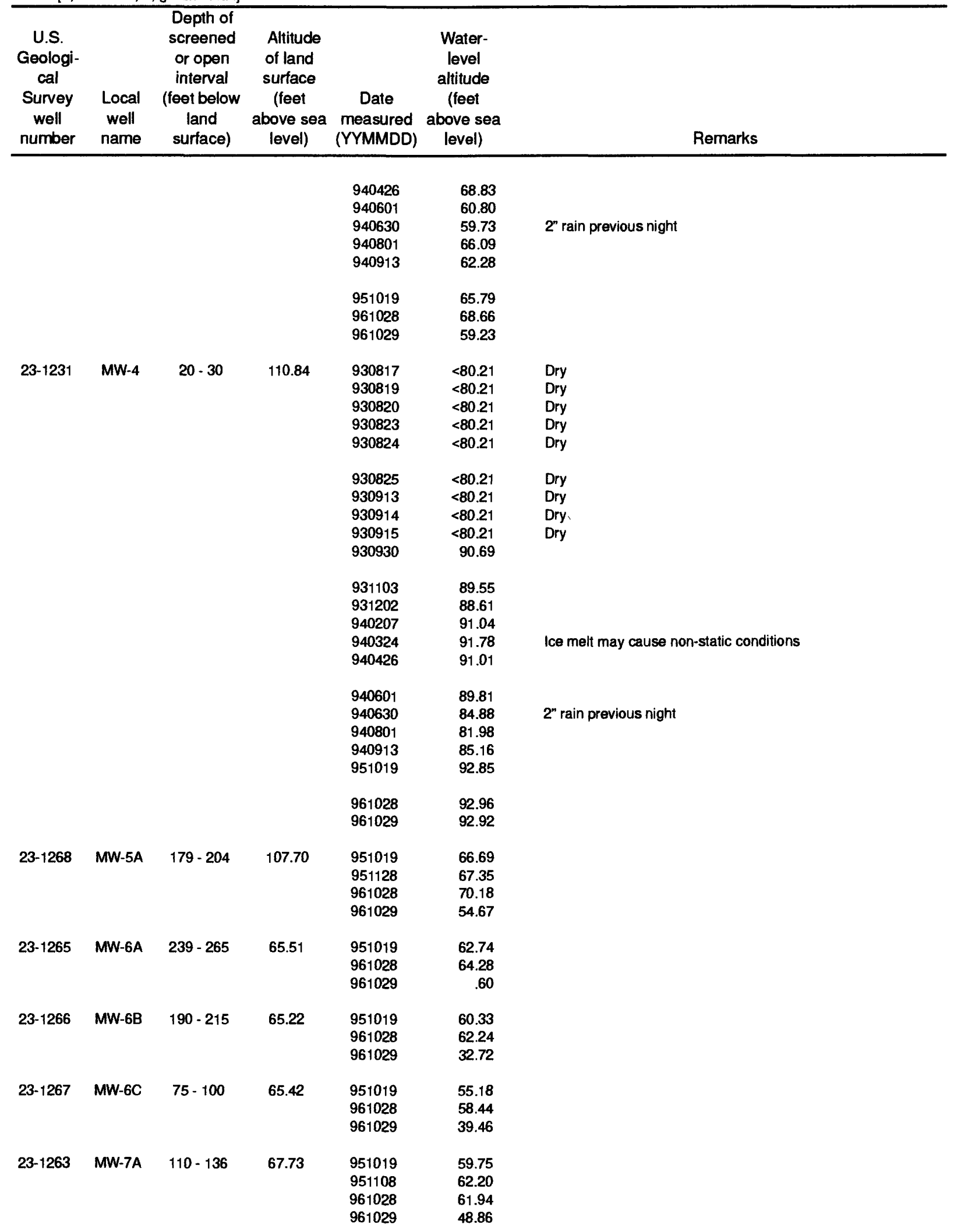


Appendix 1. Water-level altitudes in wells, Rutgers University Busch campus and vicinity, Piscataway Township, New Jersey, 1992-96 --Continued

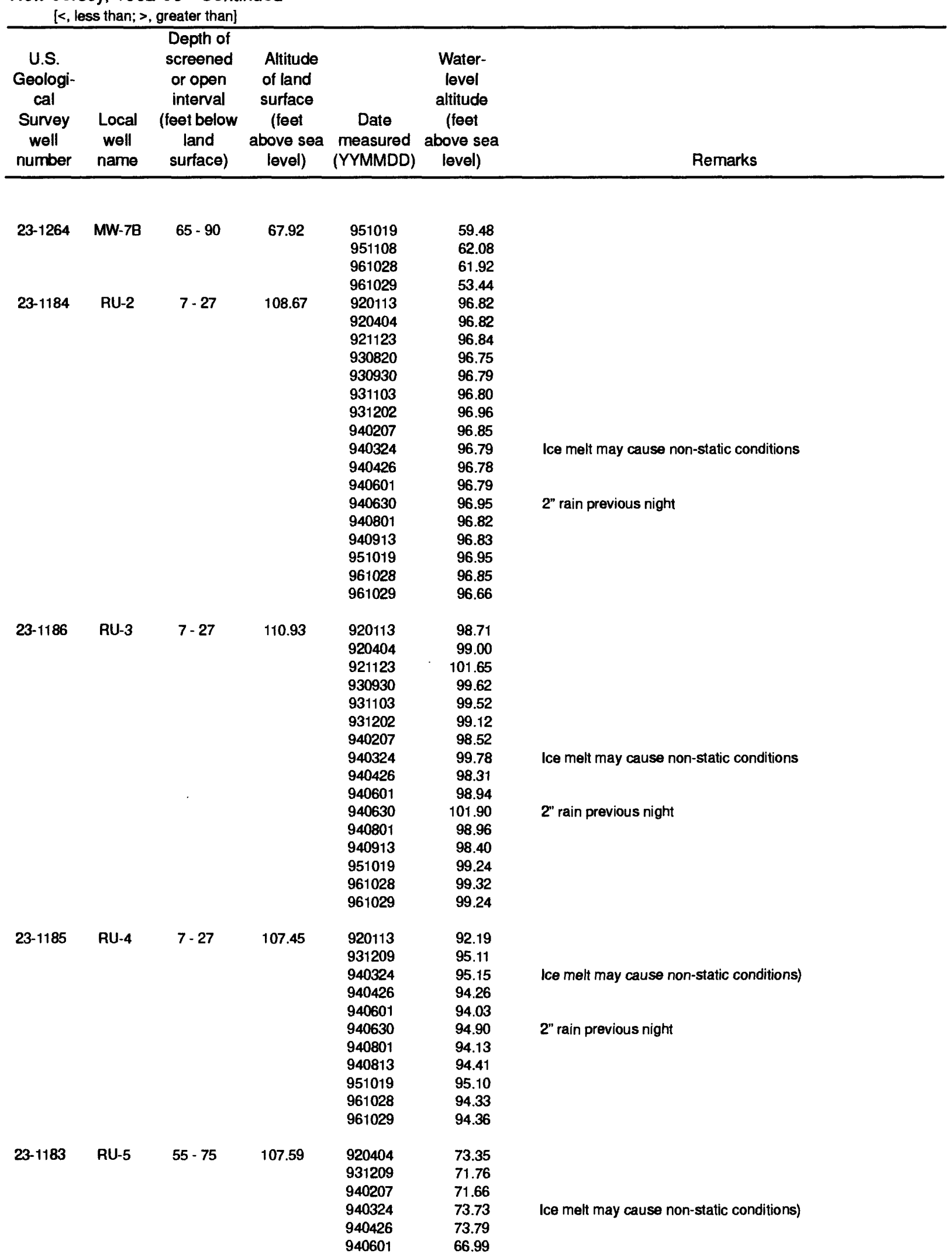


Appendix 1. Water-level altitudes in wells, Rutgers University Busch campus and vicinity, Piscataway Township, New Jersey, 1992-96 --Continued

$[<$, less than; >, greater than]

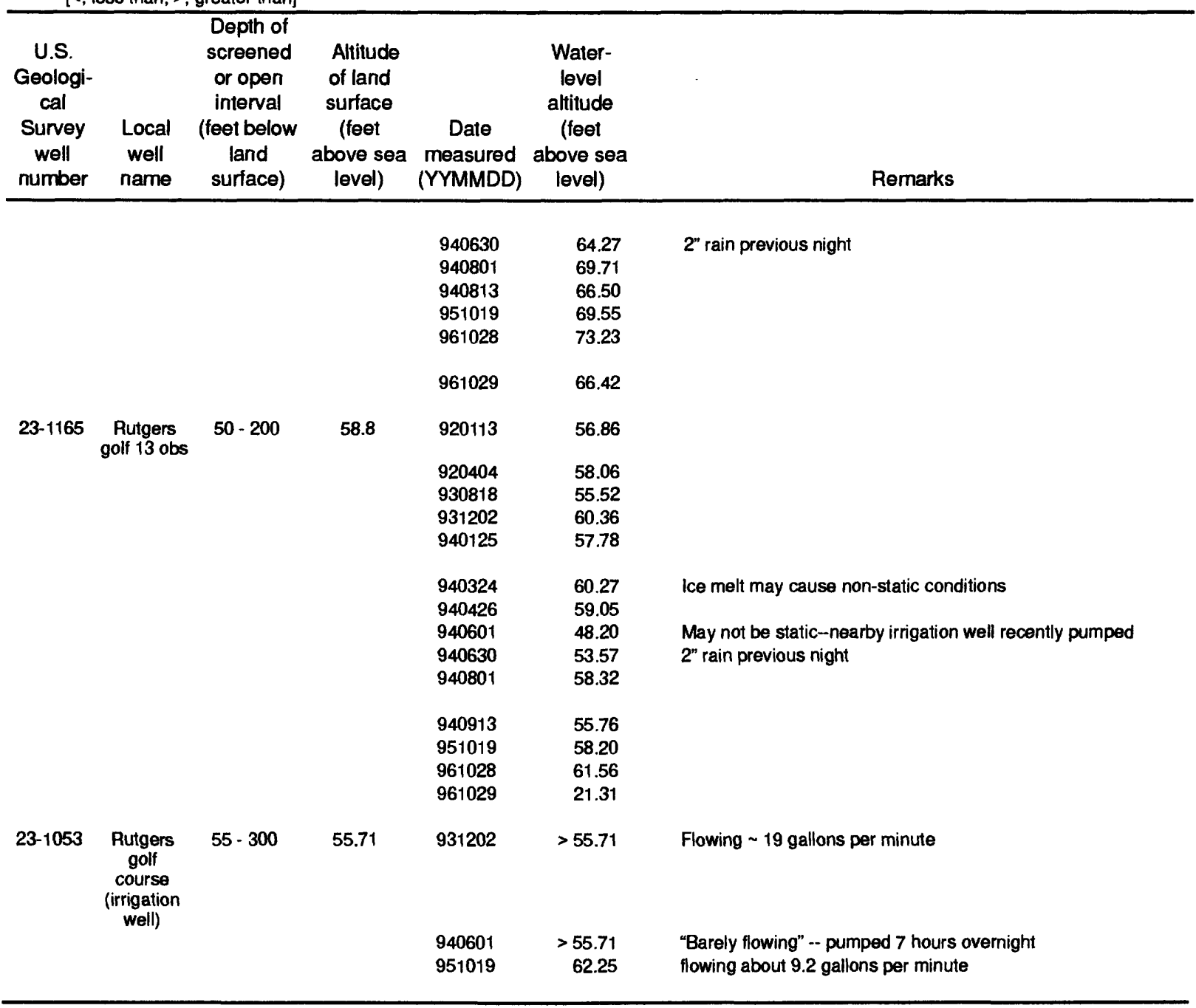


Appendix 2. Volatile organic compounds determined in ground-water samples, Rutgers University Busch Campus and vicinity, Piscataway Township, New Jersey

\begin{tabular}{|c|c|c|c|}
\hline Compound & $\begin{array}{l}\text { Reporting limit } \\
\text { (micrograms per } \\
\text { liter) }\end{array}$ & Compound & $\begin{array}{c}\text { Reporting limit } \\
\text { (micrograms per } \\
\text { liter) }\end{array}$ \\
\hline Benzene & 0.50 & 1,3-Dichloropropane & .50 \\
\hline Bromobenzene & .50 & 2,2-Dichloropropane & .50 \\
\hline Bromochloromethane & .50 & 1,1-Dichloropropene & .50 \\
\hline Bromodichloromethane & .50 & cis-1,3-Dichloropropene & .50 \\
\hline Bromoform & .50 & trans-1,3-Dichloropropene & .50 \\
\hline Bromomethane & .50 & Ethylbenzene & .50 \\
\hline n-Butylbenzene & .50 & Hexachlorobutadiene & .50 \\
\hline sec-Butylbenzene & .50 & 1-Methylethylbenzene (Cumene) & .50 \\
\hline tert-Butylbenzene & .50 & p-Isopropyltoluene (p-Cymene & .50 \\
\hline Carbon tetrachloride & .50 & Methylene chloride & .50 \\
\hline Chlorobenzene & .50 & Napthalene & .50 \\
\hline Chloroethane & .50 & n-Propylbenzene & .50 \\
\hline Chloroform & .50 & Styrene & .50 \\
\hline Chloromethane & .50 & 1,1,1,2-Tetrachloroethane & .50 \\
\hline 2-Chlorotoluene & .50 & 1,1,2,2-Tetrachloroethane & .50 \\
\hline 4-Chlorotoluene & .50 & Tetrachloroethene & .50 \\
\hline Dibromochloromethane & .50 & Toluene & .50 \\
\hline 1,2-Dibromo-3-chloro-propane & .50 & 1,2,3-Trichlorobenzene & .50 \\
\hline 1,2-Dibromomethane & .50 & 1,2,4-Trichlorobenzene & .50 \\
\hline Dibromomethane & .50 & 1,1,1-Trichloroethane & \\
\hline 1,2-Dichlorobenzene & .50 & 1,1,2-Trichloroethylane & .50 \\
\hline 1,3-Dichlorobenzene & .50 & Trichloroethene & .50 \\
\hline 1,4-Dichlorobenzene & .50 & Trichlorofluoromethane & .50 \\
\hline Dichlorodifluoromethane & .50 & 1,2,3-Trichloropropane & .50 \\
\hline 1,1-Dichloroethane & .50 & 1,2,4-Trimethylbenzene & .50 \\
\hline 1,2-Dichloroethane & .50 & 1,3,5-Trimethylbenzene & .50 \\
\hline 1,1-Dichloroethene & .50 & Vinyl chloride & .50 \\
\hline cis-1,2-Dichloroethene & .50 & o-Xylene & .50 \\
\hline trans-1,2-Dichloroethene & .50 & meta/para-Xylene & 1.0 \\
\hline 1,2-Dichloropropane & .50 & & \\
\hline
\end{tabular}


Appendix 3. Selected chemical constituents in ground-water samples collected at Rutgers University Busch Campus and vicinity, Piscataway Township, New Jersey, 1993-94

[Well locations are shown in figure 2; mg/, milligrams per liter; $\mu \mathrm{g} /$, micrograms per liter; --, no data; PCB, polychlorinated biphenyl; <, less than; ANC, acidneutralizing capacity; $E$, compound was positively detected but the amount detected is below where it can be reliably quantified]

\begin{tabular}{|c|c|c|c|c|c|c|c|c|c|c|}
\hline $\begin{array}{c}\text { U.S. Geo- } \\
\text { logical } \\
\text { Survey } \\
\text { well } \\
\text { number }\end{array}$ & Local & II name & $\begin{array}{c}\text { Date } \\
\text { sampled }\end{array}$ & $\begin{array}{l}\text { Depth of well } \\
\text { (feet below } \\
\text { land surface) }\end{array}$ & $\begin{array}{c}\text { Calcium, } \\
\text { dissolved } \\
\text { (mg/L } \\
\text { as Ca) }\end{array}$ & $\begin{array}{c}\text { Magnesium, } \\
\text { dissolved } \\
\text { (mg } / \\
\text { as Mg) }\end{array}$ & $\begin{array}{c}\text { Sodium, } \\
\text { dissolved } \\
\text { (mg/ } \\
\text { as } \mathrm{Na} \text { ) }\end{array}$ & $\begin{array}{c}\text { Potassium, } \\
\text { dissolved } \\
\text { (mg/ } \\
\text { as k) }\end{array}$ & $\begin{array}{c}\text { ANC, } \\
\text { lab } \\
(\mathrm{mg} / \mathrm{Las} \\
\left.\mathrm{CaCO}_{3}\right)\end{array}$ & $\begin{array}{c}\text { Sulfate, } \\
\text { dissolved } \\
\text { (mg/ } \\
\left.\text { as } \mathrm{SO}_{4}\right)\end{array}$ \\
\hline $\begin{array}{l}23-1219 \\
23-1218 \\
23-1232 \\
23-1226\end{array}$ & $\begin{array}{l}\text { CH-2MWA } \\
\text { CH-2MWB } \\
\text { CH-3MW } \\
\text { MW-1A }\end{array}$ & & $\begin{array}{l}08-24-93 \\
08-23-93 \\
08-19-93 \\
09-14-93\end{array}$ & $\begin{array}{r}90 \\
40 \\
160 \\
100\end{array}$ & $\begin{array}{r}17.3 \\
50.8 \\
5.3 \\
28.3\end{array}$ & $\begin{array}{r}4.1 \\
10.9 \\
3.0 \\
9.8\end{array}$ & $\begin{array}{l}10.4 \\
12.4 \\
26.8 \\
13.2\end{array}$ & $\begin{array}{r}<5.0 \\
E 1.4 \\
25.7 \\
E 2.9\end{array}$ & $\begin{array}{c}37.4 \\
130 \\
55.0 \\
136\end{array}$ & \begin{tabular}{r|}
26.4 \\
14.5 \\
31.3 \\
E 1.1
\end{tabular} \\
\hline $\begin{array}{l}23-1227 \\
23-1228 \\
23-1223 \\
23-1224\end{array}$ & $\begin{array}{l}M W-1 B \\
M W-1 C \\
M W-2 A \\
M W-2 B\end{array}$ & & $\begin{array}{l}09-15-93 \\
07-06-94 \\
08-17-93 \\
08-18-93\end{array}$ & $\begin{array}{r}140 \\
40 \\
170 \\
110\end{array}$ & $\begin{array}{l}27.9 \\
66.4 \\
39.6 \\
27.9\end{array}$ & $\begin{array}{l}13.1 \\
14.5 \\
21.3 \\
11.6\end{array}$ & $\begin{array}{l}12.9 \\
18.1 \\
41.1 \\
28.1\end{array}$ & $\begin{array}{r}E 4.1 \\
<5.0 \\
7.2 \\
7.0\end{array}$ & $\begin{array}{c}140 \\
201 \\
79.2 \\
110\end{array}$ & $\begin{array}{c}11.2 \\
15 \\
346.0 \\
41.4\end{array}$ \\
\hline $\begin{array}{l}23-1225 \\
23-1229 \\
23-1230 \\
23-1053\end{array}$ & $\begin{array}{l}\text { MW-2C } \\
M W-3 A \\
M W-3 B \\
\text { Rutgers go } \\
\text { (irrigation }\end{array}$ & ourse & $\begin{array}{l}08-18-93 \\
08-25-93 \\
09-13-93 \\
08-17-93\end{array}$ & $\begin{array}{r}80 \\
140 \\
90 \\
300\end{array}$ & $\begin{array}{l}48.4 \\
28.2 \\
44.5 \\
445\end{array}$ & $\begin{array}{l}12.6 \\
14.4 \\
14.0 \\
51.3\end{array}$ & $\begin{array}{l}16.0 \\
13.6 \\
14.9 \\
96.2\end{array}$ & $\begin{array}{l}\text { E } 2.2 \\
\text { E } 3.1 \\
\text { E } 2.9 \\
\text { E } 4.6\end{array}$ & $\begin{array}{l}114 \\
165 \\
170 \\
103\end{array}$ & $\begin{array}{r}43.1 \\
E 2.8 \\
E 2.7 \\
2,030\end{array}$ \\
\hline $\begin{array}{c}\text { U.S. Geo- } \\
\text { logical } \\
\text { Survey } \\
\text { well } \\
\text { number }\end{array}$ & $\begin{array}{c}\text { Date } \\
\text { sampled }\end{array}$ & $\begin{array}{c}\text { Chloride, } \\
\text { dissolved } \\
\text { (mg/L } \\
\text { as Cl) }\end{array}$ & $\begin{array}{l}\text { Fluoride, } \\
\text { dissolved } \\
\text { (mg/ } \\
\text { as F) }\end{array}$ & $\begin{array}{c}\text { Nitrogen, } \\
\text { nitrite } \\
\text { dissolved } \\
(\mathrm{mg} / \\
\text { as } N)\end{array}$ & $\begin{array}{l}\text { Nitrogen, } \\
\text { nitrate } \\
\text { dissolved } \\
\text { (mg/L } \\
\text { as N) }\end{array}$ & $\begin{array}{l}\text { Nitrogen, } \\
\text { ammonia } \\
\text { dissolved } \\
\text { (mg/L } \\
\text { as N) }\end{array}$ & $\begin{array}{c}\text { Arsenic, } \\
\text { dissolved } \\
(\mu g / \text { as As) }\end{array}$ & $\begin{array}{c}\text { Barium, } \\
\text { dissolved } \\
\text { ( } \mu \mathrm{g} / \\
\text { as Ba) }\end{array}$ & $\begin{array}{l}\text { Beryl- } \\
\text { lium, } \\
\text { dissolved } \\
\text { ( } \mu g / L \\
\text { as Be) }\end{array}$ & $\begin{array}{c}\text { Cadmium, } \\
\text { dissolved } \\
\text { ( } \mu g / 2 \\
\text { as Cd) }\end{array}$ \\
\hline $\begin{array}{l}23-1219 \\
23-1218 \\
23-1232 \\
23-1226\end{array}$ & $\begin{array}{l}08-24-93 \\
08-23-93 \\
08-19-93 \\
09-14-93\end{array}$ & $\begin{array}{r}13.3 \\
45.8 \\
26.2 \\
5.3\end{array}$ & $\begin{array}{l}0.12 \\
E .05 \\
<.1 \\
<.1\end{array}$ & $\begin{array}{l}.29 \\
.24 \\
.085 \\
.056\end{array}$ & $\begin{array}{l}.16 \\
.86 \\
.18 \\
1.3\end{array}$ & $\begin{array}{l}<0.20 \\
<.20 \\
<.20 \\
<.20\end{array}$ & $\begin{array}{l}\text { E } 3.4 \\
<5.0 \\
<5.0 \\
<5.0\end{array}$ & $\begin{array}{r}110 \\
540 \\
17 \\
280\end{array}$ & $\begin{array}{l}<2.0 \\
<2.0 \\
<2.0 \\
<2.0\end{array}$ & $\begin{array}{l}<5.0 \\
<5.0 \\
<5.0 \\
<5.0\end{array}$ \\
\hline $\begin{array}{l}23-1227 \\
23-1228 \\
23-1223 \\
23-1224\end{array}$ & $\begin{array}{l}09-15-93 \\
07-06-94 \\
08-17-93 \\
08-18-93\end{array}$ & $\begin{array}{r}2.1 \\
13.0 \\
6.7 \\
17.6\end{array}$ & $\begin{array}{l}<.1 \\
\text { E } .053 \\
<.1 \\
\text { E } .05\end{array}$ & $\begin{array}{l}\text { E .016 } \\
\text { E .049 } \\
\text { E.016 } \\
<.050\end{array}$ & $\begin{array}{l}.57 \\
.094 \\
.14 \\
.27\end{array}$ & $\begin{array}{l}<.20 \\
E .15 \\
<.20 \\
<.20\end{array}$ & $\begin{array}{l}<5.0 \\
E 2.8 \\
<5.0 \\
<5.0\end{array}$ & $\begin{array}{r}100 \\
880 \\
<10 \\
23\end{array}$ & $\begin{array}{l}<2.0 \\
<2.0 \\
<2.0 \\
<2.0\end{array}$ & $\begin{array}{l}<5.0 \\
<5.0 \\
<5.0 \\
<5.0\end{array}$ \\
\hline $\begin{array}{l}23-1225 \\
23-1229 \\
23-1230 \\
23-1053\end{array}$ & $\begin{array}{l}08-18-93 \\
08-25-93 \\
09-13-93 \\
08-17-93\end{array}$ & $\begin{array}{r}35.8 \\
4.1 \\
26.4 \\
18.8\end{array}$ & $\begin{array}{l}<.1 \\
<.1 \\
<.1 \\
\quad .11\end{array}$ & $\begin{array}{r}<.050 \\
\text { E } .023 \\
.051 \\
<.050\end{array}$ & $\begin{array}{c}1.5 \\
.40 \\
.93 \\
\text { E.02 }\end{array}$ & $\begin{array}{l}<.20 \\
<.20 \\
<.20 \\
<.20\end{array}$ & $\begin{array}{r}<5.0 \\
6.7 \\
<5.0 \\
\text { E } 3.9\end{array}$ & $\begin{array}{l}210 \\
150 \\
390 \\
<10\end{array}$ & $\begin{array}{l}<2.0 \\
<2.0 \\
<2.0 \\
<2.0\end{array}$ & $\begin{array}{l}<5.0 \\
<5.0 \\
<5.0 \\
<5.0\end{array}$ \\
\hline $\begin{array}{c}\text { U.S. Geo- } \\
\text { logical } \\
\text { Survey } \\
\text { well } \\
\text { number }\end{array}$ & $\begin{array}{c}\text { Date } \\
\text { sampled }\end{array}$ & $\begin{array}{c}\text { Chromium, } \\
\text { dissolved } \\
(\mu g / 2 \\
\text { as } \mathrm{Cr})\end{array}$ & $\begin{array}{c}\text { Copper, } \\
\text { dissolved } \\
(\mu g h / \\
\text { as Cu) }\end{array}$ & $\begin{array}{l}\text { Iron, } \\
\text { dissolved } \\
(\mu \mathrm{g} / \\
\text { as } \mathrm{Fe})\end{array}$ & $\begin{array}{c}\text { Lead, } \\
\text { dissolved } \\
(\mu \mathrm{g} / \\
\text { as } \mathrm{Pb})\end{array}$ & $\begin{array}{c}\text { Manganese } \\
\text { dissolved } \\
(\mu \mathrm{g} / \\
\text { as } \mathrm{Mn})\end{array}$ & $\begin{array}{c}\text { Nickel, } \\
\text { dissolved } \\
\text { ( } \mu \mathrm{g} / \\
\text { as } \\
\text { Ni) }\end{array}$ & $\begin{array}{c}\text { Zinc, } \\
\text { dissolved } \\
(\mu g \AA \\
\text { as } Z n)\end{array}$ & $\begin{array}{c}\text { Mercury, } \\
\text { dissolved } \\
(\mu g / 2 \\
\text { as } \mathrm{Hg})\end{array}$ & $\begin{array}{c}\text { Phenols, } \\
\text { total } \\
(\mu g /))\end{array}$ \\
\hline $\begin{array}{l}23-1219 \\
23-1218 \\
23-1232 \\
23-1226\end{array}$ & $\begin{array}{l}08-24-93 \\
08-23-93 \\
08-19-93 \\
09-14-93\end{array}$ & $\begin{array}{l}<10 \\
<10 \\
<10 \\
<10\end{array}$ & $\begin{array}{l}<10 \\
<10 \\
<10 \\
<10\end{array}$ & $\begin{array}{c}<100 \\
E 7.2 \\
<100 \\
\text { E } 6.2\end{array}$ & $\begin{aligned}< & 7.5 \\
< & 7.5 \\
& \quad \\
< & 7.5\end{aligned}$ & $\begin{array}{r}<10 \\
81 \\
<10 \\
16\end{array}$ & $\begin{array}{l}<40 \\
<40 \\
<40 \\
<40\end{array}$ & $\begin{array}{l}<20 \\
<20 \\
<20 \\
<20\end{array}$ & $\begin{array}{l}<0.20 \\
<.20 \\
<.20 \\
<.20\end{array}$ & $\begin{array}{r}220 \\
37 \\
46 \\
32\end{array}$ \\
\hline $\begin{array}{l}23-1227 \\
23-1228 \\
23-1223 \\
23-1224\end{array}$ & $\begin{array}{l}09-15-93 \\
07-06-94 \\
08-17-93 \\
08-18-93\end{array}$ & $\begin{array}{l}<10 \\
<10 \\
<10 \\
<10\end{array}$ & $\begin{array}{l}<10 \\
<10 \\
<10 \\
<10\end{array}$ & $\begin{array}{r}<100 \\
260 \\
<100 \\
<100\end{array}$ & $\begin{array}{c}-- \\
<\overline{7} .5 \\
--\end{array}$ & $\begin{array}{l}49 \\
59 \\
81 \\
21\end{array}$ & $\begin{array}{l}<40 \\
<40 \\
<40 \\
<40\end{array}$ & $\begin{array}{l}<20 \\
<20 \\
<20 \\
<20\end{array}$ & $\begin{array}{l}<.20 \\
<.20 \\
<.20 \\
<.20\end{array}$ & $\begin{array}{r}20 \\
78 \\
<10 \\
20\end{array}$ \\
\hline $\begin{array}{l}23-1225 \\
23-1229 \\
23-1230 \\
23-1053\end{array}$ & $\begin{array}{l}08-18-93 \\
08-25-93 \\
09-13-93 \\
08-17-93\end{array}$ & $\begin{array}{l}<10 \\
<10 \\
<10 \\
<10\end{array}$ & $\begin{array}{l}<10 \\
<10 \\
<10 \\
<10\end{array}$ & $\begin{array}{l}320 \\
\text { E } 9.9 \\
\text { E } 6.2 \\
260\end{array}$ & $\begin{aligned} & - \\
< & 7.5 \\
< & 7.5 \\
< & 7.5\end{aligned}$ & $\begin{array}{r}260 \\
16 \\
26 \\
350\end{array}$ & $\begin{array}{l}<40 \\
<40 \\
<40 \\
<40\end{array}$ & $\begin{array}{l}\text { E2.7 } \\
<20 \\
<20 \\
310\end{array}$ & $\begin{array}{l}<.20 \\
<.20 \\
<.20 \\
<.20\end{array}$ & $\begin{array}{r}24 \\
33 \\
710 \\
17\end{array}$ \\
\hline
\end{tabular}


Appendix 3. Selected chemical constituents in ground-water samples collected at Rutgers University Busch Campus and vicinity, Piscataway Township, New Jersey, 1993-94--Continued

\begin{tabular}{|c|c|c|c|c|c|c|c|c|}
\hline $\begin{array}{c}\text { U.S. Geo- } \\
\text { logical } \\
\text { Survey } \\
\text { well } \\
\text { number }\end{array}$ & $\begin{array}{c}\text { Date } \\
\text { sampled }\end{array}$ & $\begin{array}{c}\text { Aroclor } 1016 \\
\text { PCB } \\
\text { total } \\
(\mu \mathrm{g} /)\end{array}$ & $\begin{array}{c}\text { Aroclor } 1221 \\
\text { PCB } \\
\text { total } \\
(\mu \mathrm{g} / \mathrm{L})\end{array}$ & $\begin{array}{c}\text { Aroclor } 1232 \\
\text { PCB } \\
\text { total } \\
(\mu \mathrm{g} /)\end{array}$ & $\begin{array}{c}\text { Aroclor } 1242 \\
\text { PCB } \\
\text { total } \\
(\mu \mathrm{g} \Lambda)\end{array}$ & $\begin{array}{c}\text { Aroclor } 1248 \\
\text { PCB } \\
\text { total } \\
(\mu \mathrm{g} \Lambda)\end{array}$ & $\begin{array}{c}\text { Aroclor } 1254 \\
\text { PCB } \\
\text { total } \\
(\mu g \Lambda)\end{array}$ & $\begin{array}{c}\text { Aroclor } 1260 \\
\text { PCB } \\
\text { total } \\
(\mu g / L)\end{array}$ \\
\hline $\begin{array}{l}23-1219 \\
23-1218 \\
23-1232 \\
23-1226\end{array}$ & $\begin{array}{l}08-24-93 \\
08-23-93 \\
08-19-93 \\
09-14-93\end{array}$ & $\begin{array}{l}<0.50 \\
<.50 \\
<.50 \\
<.50\end{array}$ & $\begin{array}{l}<0.50 \\
<.50 \\
<.50 \\
<.50\end{array}$ & $\begin{array}{l}<0.50 \\
<.50 \\
<.50 \\
<.50\end{array}$ & $\begin{array}{l}<0.50 \\
<.50 \\
<.50 \\
<.50\end{array}$ & $\begin{array}{l}<.50 \\
<.50 \\
<.50 \\
<.50\end{array}$ & $\begin{array}{l}<1 \\
<1 \\
<1 \\
<1\end{array}$ & $\begin{array}{l}<1 \\
<1 \\
<1 \\
<1\end{array}$ \\
\hline $\begin{array}{l}23-1227 \\
23-1228 \\
23-1223 \\
23-1224\end{array}$ & $\begin{array}{l}09-15-93 \\
07-06-94 \\
08-17-93 \\
08-18-93\end{array}$ & $\begin{array}{l}<.50 \\
<.50 \\
<.50 \\
<.50\end{array}$ & $\begin{array}{l}<.50 \\
<.50 \\
<.50 \\
<.50\end{array}$ & $\begin{array}{l}<.50 \\
<.50 \\
<.50 \\
<.50\end{array}$ & $\begin{array}{l}<.50 \\
<.50 \\
<.50 \\
<.50\end{array}$ & $\begin{array}{l}<.50 \\
<.50 \\
<.50 \\
<.50\end{array}$ & $\begin{array}{l}<1 \\
<1 \\
<1 \\
<1\end{array}$ & $\begin{array}{l}<1 \\
<1 \\
<1 \\
<1\end{array}$ \\
\hline $\begin{array}{l}23-1225 \\
23-1229 \\
23-1230\end{array}$ & $\begin{array}{l}08-18-93 \\
08-25-93 \\
09-13-93\end{array}$ & $\begin{array}{l}<.50 \\
<.50 \\
--\end{array}$ & $\begin{array}{l}<.50 \\
<.50 \\
--\end{array}$ & $\begin{array}{l}<.50 \\
<.50 \\
--\end{array}$ & $\begin{array}{l}<.50 \\
<.50 \\
--\end{array}$ & $\begin{array}{l}<.50 \\
<.50 \\
--\end{array}$ & $\begin{array}{r}<1 \\
<1 \\
-.\end{array}$ & $\begin{array}{r}<1 \\
<1 \\
\quad-.\end{array}$ \\
\hline 23-1053 & $08-17-93$ & $<.50$ & $<.50$ & $<.50$ & $<.50$ & $<.50$ & $<1$ & $<1$ \\
\hline
\end{tabular}


Appendix 4. Maximum contaminant levels for selected organic compounds and inorganic constituents, New Jersey

[Maximum contaminant levels from New Jersey Administrative Code, 1990]

\begin{tabular}{|c|c|}
\hline Organic compound & $\begin{array}{l}\text { Maximum contaminant level } \\
\text { (micrograms per liter) }\end{array}$ \\
\hline Benzene & 1 \\
\hline Carbon tetrachloride & 2 \\
\hline meta-Dichlorobenzene & 600 \\
\hline ortho-Dichlorobenzene & 600 \\
\hline para-Dichlorobenzene & 75 \\
\hline 1,2-Dichloroethane & 2 \\
\hline 1,1-Dichloroethylene & 2 \\
\hline cis-1,2-Dichloroethylene & 10 \\
\hline trans-1,2-Dichloroethylene & 10 \\
\hline Methylene chloride & 2 \\
\hline Polychlorinated biphenyls & .5 \\
\hline Tetrachloroethylene & 1 \\
\hline Toluene & 1,000 \\
\hline 1,2,4-Trichlorobenzene & 8 \\
\hline 1,1,1-Trichloroethane & 26 \\
\hline Trichloroethylene & 1 \\
\hline Trihalomethanes & 100 \\
\hline Vinyl chloride & 2 \\
\hline Xylenes (total) & 44 \\
\hline \multicolumn{2}{|l|}{ Inorganic constituent } \\
\hline Arsenic & 50 \\
\hline Barium & 2,000 \\
\hline Beryllium & 4 \\
\hline Cadmium & 5 \\
\hline Chromium & 100 \\
\hline Cyanide & 200 \\
\hline Fluoride & 4,000 \\
\hline Mercury & 2 \\
\hline Nickel & 100 \\
\hline Nitrate (as nitrogen) & 10,000 \\
\hline Nitrite & 1,000 \\
\hline Nitrate/nitrite & 10,000 \\
\hline Selenium & 50 \\
\hline
\end{tabular}


Appendix 5. Results of analyses of quality-assurance blank samples for selected organic compounds, $1993-96$

[All concentrations in micrograms per liter; <, less than minimum reporting limit]

\begin{tabular}{|c|c|c|c|c|c|c|c|c|c|c|c|}
\hline Sample type & Date & Benzene & $\begin{array}{l}\text { Bromo- } \\
\text { benzene }\end{array}$ & $\begin{array}{l}\text { Bromo- } \\
\text { chloro- } \\
\text { methane }\end{array}$ & $\begin{array}{l}\text { Bromo- } \\
\text { dichloro- } \\
\text { methane }\end{array}$ & Bromoform & $\begin{array}{l}\text { Bromo- } \\
\text { methane } \\
\text { (methyl } \\
\text { bromide) }\end{array}$ & $\begin{array}{l}\text { n-Butyl- } \\
\text { benzene }\end{array}$ & $\begin{array}{l}\text { sec-Butyl- } \\
\text { benzene }\end{array}$ & $\begin{array}{l}\text { tert-Butyl- } \\
\text { benzene }\end{array}$ & $\begin{array}{l}\text { Carbon } \\
\text { tetrachloride }\end{array}$ \\
\hline $\begin{array}{l}\text { Field blank } \\
\text { Field blank } \\
\text { Trip blank } \\
\text { Trip blank } \\
\text { Field blank }\end{array}$ & $\begin{array}{l}08-19-93 \\
08-25-93 \\
08-19-93 \\
09-14-93 \\
07-06-94\end{array}$ & $\begin{array}{l}<0.5 \\
<.5 \\
<.5 \\
<.5 \\
<.5\end{array}$ & $\begin{array}{l}<0.5 \\
<.5 \\
<.5 \\
<.5 \\
<.5\end{array}$ & $\begin{array}{l}<0.5 \\
<.5 \\
<.5 \\
<.5 \\
<.5\end{array}$ & $\begin{array}{l}<0.5 \\
<.5 \\
<.5 \\
<.5 \\
<.5\end{array}$ & $\begin{array}{l}<0.5 \\
<.5 \\
<.5 \\
<.5 \\
<.5\end{array}$ & $\begin{array}{l}<0.5 \\
<.5 \\
<.5 \\
<.5 \\
<.5\end{array}$ & $\begin{array}{l}<0.5 \\
<.5 \\
<.5 \\
<.5 \\
<.5\end{array}$ & $\begin{array}{l}<0.5 \\
<.5 \\
<.5 \\
<.5 \\
<.5\end{array}$ & $\begin{array}{l}<0.5 \\
<.5 \\
<.5 \\
<.5 \\
<.5\end{array}$ & $\begin{array}{l}<0.5 \\
<.5 \\
<.5 \\
<.5 \\
<.5\end{array}$ \\
\hline $\begin{array}{l}\text { Field blank } \\
\text { Field blank } \\
\text { Field blank } \\
\text { Field blank } \\
\text { Trip blank }\end{array}$ & $\begin{array}{l}07-08-94 \\
07-12-94 \\
07-14-94 \\
07-15-94 \\
07-06-94\end{array}$ & $\begin{array}{l}<.5 \\
<.5 \\
<.5 \\
<.5 \\
<.5\end{array}$ & $\begin{array}{l}<.5 \\
<.5 \\
<.5 \\
<.5 \\
<.5\end{array}$ & $\begin{array}{l}<.5 \\
<.5 \\
<.5 \\
<.5 \\
<.5\end{array}$ & $\begin{array}{l}<.5 \\
<.5 \\
<.5 \\
<.5 \\
<.5\end{array}$ & $\begin{array}{l}<.5 \\
<.5 \\
<.5 \\
<.5 \\
<.5\end{array}$ & $\begin{array}{l}<.5 \\
<.5 \\
<.5 \\
<.5 \\
<.5\end{array}$ & $\begin{array}{l}<.5 \\
<.5 \\
<.5 \\
<.5 \\
<.5\end{array}$ & $\begin{array}{l}<.5 \\
<.5 \\
<.5 \\
<.5 \\
<.5\end{array}$ & $\begin{array}{l}<.5 \\
<.5 \\
<.5 \\
<.5 \\
<.5\end{array}$ & $\begin{array}{l}<.5 \\
<.5 \\
<.5 \\
<.5 \\
<.5\end{array}$ \\
\hline $\begin{array}{l}\text { Trip blank } \\
\text { Trip blank } \\
\text { Trip blank } \\
\text { Field blank } \\
\text { Trip blank }\end{array}$ & $\begin{array}{l}07-08-94 \\
07-12-94 \\
07-14-94 \\
01-19-95 \\
01-18-95\end{array}$ & $\begin{array}{l}<.5 \\
<.5 \\
<.5 \\
<.5 \\
<.5\end{array}$ & $\begin{array}{l}<.5 \\
<.5 \\
<.5 \\
<.5 \\
<.5\end{array}$ & $\begin{array}{l}<.5 \\
<.5 \\
<.5 \\
<.5 \\
<.5\end{array}$ & $\begin{array}{l}<.5 \\
<.5 \\
<.5 \\
<.5 \\
<.5\end{array}$ & $\begin{array}{l}<.5 \\
<.5 \\
<.5 \\
<.5 \\
<.5\end{array}$ & $\begin{array}{l}<.5 \\
<.5 \\
<.5 \\
<.5 \\
<.5\end{array}$ & $\begin{array}{l}<.5 \\
<.5 \\
<.5 \\
<.5 \\
<.5\end{array}$ & $\begin{array}{l}<.5 \\
<.5 \\
<.5 \\
<.5 \\
<.5\end{array}$ & $\begin{array}{l}<.5 \\
<.5 \\
<.5 \\
<.5 \\
<.5\end{array}$ & $\begin{array}{l}<.5 \\
<.5 \\
<.5 \\
<.5 \\
<.5\end{array}$ \\
\hline $\begin{array}{l}\text { Equipment blank } \\
\text { Field blank } \\
\text { Field blank } \\
\text { Field blank } \\
\text { Field blank }\end{array}$ & $\begin{array}{l}08-23-95 \\
09-19-95 \\
09-20-95 \\
09-21-95 \\
09-26-95\end{array}$ & $\begin{array}{l}<.5 \\
<.5 \\
<.5 \\
<.5 \\
<.5\end{array}$ & $\begin{array}{l}<.5 \\
<.5 \\
<.5 \\
<.5 \\
<.5\end{array}$ & $\begin{array}{l}<.5 \\
<.5 \\
<.5 \\
<.5 \\
<.5\end{array}$ & $\begin{array}{l}<.5 \\
<.5 \\
<.5 \\
<.5 \\
<.5\end{array}$ & $\begin{array}{l}<.5 \\
<.5 \\
<.5 \\
<.5 \\
<.5\end{array}$ & $\begin{array}{l}<.5 \\
<.5 \\
<.5 \\
<.5 \\
<.5\end{array}$ & $\begin{array}{l}<.5 \\
<.5 \\
<.5 \\
<.5 \\
<.5\end{array}$ & $\begin{array}{l}<.5 \\
<.5 \\
<.5 \\
<.5 \\
<.5\end{array}$ & $\begin{array}{l}<.5 \\
<.5 \\
<.5 \\
<.5 \\
<.5\end{array}$ & $\begin{array}{l}<.5 \\
<.5 \\
<.5 \\
<.5 \\
<.5\end{array}$ \\
\hline $\begin{array}{l}\text { Field blank } \\
\text { Field blank } \\
\text { Field blank } \\
\text { Field blank } \\
\text { Field blank }\end{array}$ & $\begin{array}{l}09-28-95 \\
11-08-95 \\
11-21-95 \\
11-22-95 \\
11-28-95\end{array}$ & $\begin{array}{l}<.5 \\
<.5 \\
<.5 \\
<.5 \\
<.5\end{array}$ & $\begin{array}{l}<.5 \\
<.5 \\
<.5 \\
<.5 \\
<.5\end{array}$ & $\begin{array}{l}<.5 \\
<.5 \\
<.5 \\
<.5 \\
<.5\end{array}$ & $\begin{array}{l}<.5 \\
<.5 \\
<.5 \\
<.5 \\
<.5\end{array}$ & $\begin{array}{l}<.5 \\
<.5 \\
<.5 \\
<.5 \\
<.5\end{array}$ & $\begin{array}{l}<.5 \\
<.5 \\
<.5 \\
<.5 \\
<.5\end{array}$ & $\begin{array}{l}<.5 \\
<.5 \\
<.5 \\
<.5 \\
<.5\end{array}$ & $\begin{array}{l}<.5 \\
<.5 \\
<.5 \\
<.5 \\
<.5\end{array}$ & $\begin{array}{l}<.5 \\
<.5 \\
<.5 \\
<.5 \\
<.5\end{array}$ & $\begin{array}{l}<.5 \\
<.5 \\
<.5 \\
<.5 \\
<.5\end{array}$ \\
\hline $\begin{array}{l}\text { Field blank } \\
\text { Trip blank } \\
\text { Trip blank } \\
\text { Trip blank } \\
\text { Trip blank }\end{array}$ & $\begin{array}{l}11-29-95 \\
09-19-95 \\
09-20-95 \\
09-22-95 \\
09-25-95\end{array}$ & $\begin{array}{l}<.5 \\
<.5 \\
<.5 \\
<.5 \\
<.5\end{array}$ & $\begin{array}{l}<.5 \\
<.5 \\
<.5 \\
<.5 \\
<.5\end{array}$ & $\begin{array}{l}<.5 \\
<.5 \\
<.5 \\
<.5 \\
<.5\end{array}$ & $\begin{array}{l}<.5 \\
<.5 \\
<.5 \\
<.5 \\
<.5\end{array}$ & $\begin{array}{l}<.5 \\
<.5 \\
<.5 \\
<.5 \\
<.5\end{array}$ & $\begin{array}{l}<.5 \\
<.5 \\
<.5 \\
<.5 \\
<.5\end{array}$ & $\begin{array}{l}<.5 \\
<.5 \\
<.5 \\
<.5 \\
<.5\end{array}$ & $\begin{array}{l}<.5 \\
<.5 \\
<.5 \\
<.5 \\
<.5\end{array}$ & $\begin{array}{l}<.5 \\
<.5 \\
<.5 \\
<.5 \\
<.5\end{array}$ & $\begin{array}{l}<.5 \\
<.5 \\
<.5 \\
<.5 \\
<.5\end{array}$ \\
\hline $\begin{array}{l}\text { Trip blank } \\
\text { Trip blank } \\
\text { Trip blank } \\
\text { Trip blank } \\
\text { Equipment blank }\end{array}$ & $\begin{array}{l}09-28-95 \\
11-07-95 \\
11-21-95 \\
11-28-95 \\
09-11-96\end{array}$ & $\begin{array}{l}<.5 \\
<.5 \\
<.5 \\
<.5 \\
<.5\end{array}$ & $\begin{array}{l}<.5 \\
<.5 \\
<.5 \\
<.5 \\
<.5\end{array}$ & $\begin{array}{l}<.5 \\
<.5 \\
<.5 \\
<.5 \\
<.5\end{array}$ & $\begin{array}{l}<.5 \\
<.5 \\
<.5 \\
<.5 \\
<.5\end{array}$ & $\begin{array}{l}<.5 \\
<.5 \\
<.5 \\
<.5 \\
<.5\end{array}$ & $\begin{array}{l}<.5 \\
<.5 \\
<.5 \\
<.5 \\
<.5\end{array}$ & $\begin{array}{l}<.5 \\
<.5 \\
<.5 \\
<.5 \\
<.5\end{array}$ & $\begin{array}{l}<.5 \\
<.5 \\
<.5 \\
<.5 \\
<.5\end{array}$ & $\begin{array}{l}<.5 \\
<.5 \\
<.5 \\
<.5 \\
<.5\end{array}$ & $\begin{array}{l}<.5 \\
<.5 \\
<.5 \\
<.5 \\
<.5\end{array}$ \\
\hline $\begin{array}{l}\text { Field blank } \\
\text { Field blank } \\
\text { Trip blank } \\
\text { Field blank } \\
\text { Trip blank }\end{array}$ & $\begin{array}{l}09-17-96 \\
09-18-96 \\
09-17-96 \\
09-19-96 \\
09-18-96\end{array}$ & $\begin{array}{l}<.5 \\
<.5 \\
<.5 \\
<.5 \\
<.5\end{array}$ & $\begin{array}{l}<.5 \\
<.5 \\
<.5 \\
<.5 \\
<.5\end{array}$ & $\begin{array}{l}<.5 \\
<.5 \\
<.5 \\
<.5 \\
<.5\end{array}$ & $\begin{array}{l}<.5 \\
<.5 \\
<.5 \\
<.5 \\
<.5\end{array}$ & $\begin{array}{l}<.5 \\
<.5 \\
<.5 \\
<.5 \\
<.5\end{array}$ & $\begin{array}{l}<.5 \\
<.5 \\
<.5 \\
<.5 \\
<.5\end{array}$ & $\begin{array}{l}<.5 \\
<.5 \\
<.5 \\
<.5 \\
<.5\end{array}$ & $\begin{array}{l}<.5 \\
<.5 \\
<.5 \\
<.5 \\
<.5\end{array}$ & $\begin{array}{l}<.5 \\
<.5 \\
<.5 \\
<.5 \\
<.5\end{array}$ & $\begin{array}{l}<.5 \\
<.5 \\
<.5 \\
<.5 \\
<.5\end{array}$ \\
\hline $\begin{array}{l}\text { Trip blank } \\
\text { Field blank } \\
\text { Trip blank } \\
\text { Field blank } \\
\text { Field blank }\end{array}$ & $\begin{array}{l}09-23-96 \\
09-24-96 \\
09-24-96 \\
09-25-96 \\
09-26-96\end{array}$ & $\begin{array}{l}<.5 \\
<.5 \\
<.5 \\
<.5 \\
<.5\end{array}$ & $\begin{array}{l}<.5 \\
<.5 \\
<.5 \\
<.5 \\
<.5\end{array}$ & $\begin{array}{l}<.5 \\
<.5 \\
<.5 \\
<.5 \\
<.5\end{array}$ & $\begin{array}{l}<.5 \\
<.5 \\
<.5 \\
<.5 \\
<.5\end{array}$ & $\begin{array}{l}<.5 \\
<.5 \\
<.5 \\
<.5 \\
<.5\end{array}$ & $\begin{array}{l}<.5 \\
<.5 \\
<.5 \\
<.5 \\
<.5\end{array}$ & $\begin{array}{l}<.5 \\
<.5 \\
<.5 \\
<.5 \\
<.5\end{array}$ & $\begin{array}{l}<.5 \\
<.5 \\
<.5 \\
<.5 \\
<.5\end{array}$ & $\begin{array}{l}<.5 \\
<.5 \\
<.5 \\
<.5 \\
<.5\end{array}$ & $\begin{array}{l}<.5 \\
<.5 \\
<.5 \\
<.5 \\
<.5\end{array}$ \\
\hline $\begin{array}{l}\text { Trip blank } \\
\text { Field blank } \\
\text { Field blank } \\
\text { Trip blank } \\
\text { Field blank }\end{array}$ & $\begin{array}{l}10-01-96 \\
10-01-96 \\
10-02-96 \\
10-04-96 \\
10-04-96\end{array}$ & $\begin{array}{l}<.5 \\
<.5 \\
<.5 \\
<.5 \\
<.5\end{array}$ & $\begin{array}{l}<.5 \\
<.5 \\
<.5 \\
<.5 \\
<.5\end{array}$ & $\begin{array}{l}<.5 \\
<.5 \\
<.5 \\
<.5 \\
<.5\end{array}$ & $\begin{array}{l}<.5 \\
<.5 \\
<.5 \\
<.5 \\
<.5\end{array}$ & $\begin{array}{l}<.5 \\
<.5 \\
<.5 \\
<.5 \\
<.5\end{array}$ & $\begin{array}{l}<.5 \\
<.5 \\
<.5 \\
<.5 \\
<.5\end{array}$ & $\begin{array}{l}<.5 \\
<.5 \\
<.5 \\
<.5 \\
<.5\end{array}$ & $\begin{array}{l}<.5 \\
<.5 \\
<.5 \\
<.5 \\
<.5\end{array}$ & $\begin{array}{l}<.5 \\
<.5 \\
<.5 \\
<.5 \\
<.5\end{array}$ & $\begin{array}{l}<.5 \\
<.5 \\
<.5 \\
<.5 \\
<.5\end{array}$ \\
\hline $\begin{array}{l}\text { Trip blank } \\
\text { Field blank } \\
\text { Field blank } \\
\text { Field blank } \\
\text { Trip blank }\end{array}$ & $\begin{array}{c}10-07-96 \\
10-07-96 \\
10-08-96 \\
10-09-96 \\
10-09-96\end{array}$ & $\begin{array}{l}<.5 \\
<.5 \\
<.5 \\
<.5 \\
<.5\end{array}$ & $\begin{array}{l}<.5 \\
<.5 \\
<.5 \\
<.5 \\
<.5\end{array}$ & $\begin{array}{l}<.5 \\
<.5 \\
<.5 \\
<.5 \\
<.5\end{array}$ & $\begin{array}{l}<.5 \\
<.5 \\
<.5 \\
<.5 \\
<.5\end{array}$ & $\begin{array}{l}<.5 \\
<.5 \\
<.5 \\
<.5 \\
<.5\end{array}$ & $\begin{array}{l}<.5 \\
<.5 \\
<.5 \\
<.5 \\
<.5\end{array}$ & $\begin{array}{l}<.5 \\
<.5 \\
<.5 \\
<.5 \\
<.5\end{array}$ & $\begin{array}{l}<.5 \\
<.5 \\
<.5 \\
<.5 \\
<.5\end{array}$ & $\begin{array}{l}<.5 \\
<.5 \\
<.5 \\
<.5 \\
<.5\end{array}$ & $\begin{array}{l}<.5 \\
<.5 \\
<.5 \\
<.5 \\
<.5\end{array}$ \\
\hline Field blank & $10-10-96$ & $<.5$ & $<.5$ & $<.5$ & $<.5$ & $<.5$ & $<.5$ & $<.5$ & $<.5$ & $<.5$ & $<.5$ \\
\hline
\end{tabular}


Appendix 5. Results of analyses of quality-assurance blank samples for selected organic compounds, 1993-96--Continued

\begin{tabular}{|c|c|c|c|c|c|c|c|c|c|c|c|}
\hline Sample type & Date & $\begin{array}{l}\text { Chloro- } \\
\text { benzene }\end{array}$ & $\begin{array}{l}\text { Chloro- } \\
\text { ethane }\end{array}$ & Chloroform & $\begin{array}{l}\text { Chloro- } \\
\text { methane } \\
\text { (methyl } \\
\text { chloride) }\end{array}$ & $\begin{array}{l}\text { 2-Chloro- } \\
\text { toluene } \\
\text { (o-chloro- } \\
\text { toluene) }\end{array}$ & $\begin{array}{l}\text { 4-Chloro- } \\
\text { toluene } \\
\text { (p-chloro- } \\
\text { toluene }\end{array}$ & $\begin{array}{l}\text { Chloro- } \\
\text { dibromo- } \\
\text { methane }\end{array}$ & $\begin{array}{l}1,2- \\
\text { Dibromo-3- } \\
\text { chloro- } \\
\text { propane } \\
\text { (dibromo- } \\
\text { chloro- } \\
\text { propane) }\end{array}$ & $\begin{array}{l}1,2- \\
\text { Dibromo- } \\
\text { ethane }\end{array}$ & $\begin{array}{l}\text { Dibromo- } \\
\text { methane }\end{array}$ \\
\hline $\begin{array}{l}\text { Field blank } \\
\text { Field blank } \\
\text { Trip blank } \\
\text { Trip blank } \\
\text { Field blank }\end{array}$ & $\begin{array}{l}08-19-93 \\
08-25-93 \\
08-19-93 \\
09-14-93 \\
07-06-94\end{array}$ & $\begin{array}{l}<0.5 \\
<.5 \\
<.5 \\
<.5 \\
<.5\end{array}$ & $\begin{array}{l}<0.5 \\
<.5 \\
<.5 \\
<.5 \\
<.5\end{array}$ & $\begin{array}{l}<0.5 \\
<.5 \\
<.5 \\
<.5 \\
<.5\end{array}$ & $\begin{array}{l}<0.5 \\
<.5 \\
<.5 \\
<.5 \\
<.5\end{array}$ & $\begin{array}{l}<0.5 \\
<.5 \\
<.5 \\
<.5 \\
<.5\end{array}$ & $\begin{array}{l}<0.5 \\
<.5 \\
<.5 \\
<.5 \\
<.5\end{array}$ & $\begin{array}{l}<0.5 \\
<.5 \\
<.5 \\
<.5 \\
<.5\end{array}$ & $\begin{array}{l}<0.5 \\
<.5 \\
<.5 \\
<.5 \\
<.5\end{array}$ & $\begin{array}{l}<0.5 \\
<.5 \\
<.5 \\
<.5 \\
<.5\end{array}$ & $\begin{array}{l}<0.5 \\
<.5 \\
<.5 \\
<.5 \\
<.5\end{array}$ \\
\hline $\begin{array}{l}\text { Field blank } \\
\text { Field blank } \\
\text { Field blank } \\
\text { Field blank } \\
\text { Trip blank }\end{array}$ & $\begin{array}{l}07-08-94 \\
07-12-94 \\
07-14-94 \\
07-15-94 \\
07-06-94\end{array}$ & $\begin{array}{l}<.5 \\
<.5 \\
<.5 \\
<.5 \\
<.5\end{array}$ & $\begin{array}{l}<.5 \\
<.5 \\
<.5 \\
<.5 \\
<.5\end{array}$ & $\begin{array}{l}<.5 \\
<.5 \\
<.5 \\
<.5 \\
<.5\end{array}$ & $\begin{array}{l}<.5 \\
<.5 \\
<.5 \\
<.5 \\
<.5\end{array}$ & $\begin{array}{l}<.5 \\
<.5 \\
<.5 \\
<.5 \\
<.5\end{array}$ & $\begin{array}{l}<.5 \\
<.5 \\
<.5 \\
<.5 \\
<.5\end{array}$ & $\begin{array}{l}<.5 \\
<.5 \\
<.5 \\
<.5 \\
<.5\end{array}$ & $\begin{array}{l}<.5 \\
<.5 \\
<.5 \\
<.5 \\
<.5\end{array}$ & $\begin{array}{l}<.5 \\
<.5 \\
<.5 \\
<.5 \\
<.5\end{array}$ & $\begin{array}{l}<.5 \\
<.5 \\
<.5 \\
<.5 \\
<.5\end{array}$ \\
\hline $\begin{array}{l}\text { Trip blank } \\
\text { Trip blank } \\
\text { Trip blank } \\
\text { Field blank } \\
\text { Trip blank }\end{array}$ & $\begin{array}{l}07-08-94 \\
07-12-94 \\
07-14-94 \\
01-19-95 \\
01-18-95\end{array}$ & $\begin{array}{l}<.5 \\
<.5 \\
<.5 \\
<.5 \\
<.5\end{array}$ & $\begin{array}{l}<.5 \\
<.5 \\
<.5 \\
<.5 \\
<.5\end{array}$ & $\begin{array}{l}<.5 \\
<.5 \\
<.5 \\
<.5 \\
<.5\end{array}$ & $\begin{array}{l}<.5 \\
<.5 \\
<.5 \\
<.5 \\
<.5\end{array}$ & $\begin{array}{l}<.5 \\
<.5 \\
<.5 \\
<.5 \\
<.5\end{array}$ & $\begin{array}{l}<.5 \\
<.5 \\
<.5 \\
<.5 \\
<.5\end{array}$ & $\begin{array}{l}<.5 \\
<.5 \\
<.5 \\
<.5 \\
<.5\end{array}$ & $\begin{array}{l}<.5 \\
<.5 \\
<.5 \\
<.5 \\
<.5\end{array}$ & $\begin{array}{l}<.5 \\
<.5 \\
<.5 \\
<.5 \\
<.5\end{array}$ & $\begin{array}{l}<.5 \\
<.5 \\
<.5 \\
<.5 \\
<.5\end{array}$ \\
\hline $\begin{array}{l}\text { Equipment blank } \\
\text { Field blank } \\
\text { Field blank } \\
\text { Field blank } \\
\text { Field blank }\end{array}$ & $\begin{array}{l}08-23-95 \\
09-19-95 \\
09-20-95 \\
09-21-95 \\
09-26-95\end{array}$ & $\begin{array}{l}<.5 \\
<.5 \\
<.5 \\
<.5 \\
<.5\end{array}$ & $\begin{array}{l}<.5 \\
<.5 \\
<.5 \\
<.5 \\
<.5\end{array}$ & $\begin{array}{l}<.5 \\
<.5 \\
<.5 \\
<.5 \\
<.5\end{array}$ & $\begin{array}{l}<.5 \\
<.5 \\
<.5 \\
<.5 \\
<.5\end{array}$ & $\begin{array}{l}<.5 \\
<.5 \\
<.5 \\
<.5 \\
<.5\end{array}$ & $\begin{array}{l}<.5 \\
<.5 \\
<.5 \\
<.5 \\
<.5\end{array}$ & $\begin{array}{l}<.5 \\
<.5 \\
<.5 \\
<.5 \\
<.5\end{array}$ & $\begin{array}{l}<.5 \\
<.5 \\
<.5 \\
<.5 \\
<.5\end{array}$ & $\begin{array}{l}<.5 \\
<.5 \\
<.5 \\
<.5 \\
<.5\end{array}$ & $\begin{array}{l}<.5 \\
<.5 \\
<.5 \\
<.5 \\
<.5\end{array}$ \\
\hline $\begin{array}{l}\text { Field blank } \\
\text { Field blank } \\
\text { Field blank } \\
\text { Field blank } \\
\text { Field blank }\end{array}$ & $\begin{array}{l}09-28-95 \\
11-08-95 \\
11-21-95 \\
11-22-95 \\
11-28-95\end{array}$ & $\begin{array}{l}<.5 \\
<.5 \\
<.5 \\
<.5 \\
<.5\end{array}$ & $\begin{array}{l}<.5 \\
<.5 \\
<.5 \\
<.5 \\
<.5\end{array}$ & $\begin{array}{l}<.5 \\
<.5 \\
<.5 \\
<.5 \\
<.5\end{array}$ & $\begin{array}{l}<.5 \\
<.5 \\
<.5 \\
<.5 \\
<.5\end{array}$ & $\begin{array}{l}<.5 \\
<.5 \\
<.5 \\
<.5 \\
<.5\end{array}$ & $\begin{array}{l}<.5 \\
<.5 \\
<.5 \\
<.5 \\
<.5\end{array}$ & $\begin{array}{l}<.5 \\
<.5 \\
<.5 \\
<.5 \\
<.5\end{array}$ & $\begin{array}{l}<.5 \\
<.5 \\
<.5 \\
<.5 \\
<.5\end{array}$ & $\begin{array}{l}<.5 \\
<.5 \\
<.5 \\
<.5 \\
<.5\end{array}$ & $\begin{array}{l}<.5 \\
<.5 \\
<.5 \\
<.5 \\
<.5\end{array}$ \\
\hline $\begin{array}{l}\text { Field blank } \\
\text { Trip blank } \\
\text { Trip blank } \\
\text { Trip blank } \\
\text { Trip blank }\end{array}$ & $\begin{array}{l}11-29-95 \\
09-19-95 \\
09-20-95 \\
09-22-95 \\
09-25-95\end{array}$ & $\begin{array}{l}<.5 \\
<.5 \\
<.5 \\
<.5 \\
<.5\end{array}$ & $\begin{array}{l}<.5 \\
<.5 \\
<.5 \\
<.5 \\
<.5\end{array}$ & $\begin{array}{r}<.5 \\
.6 \\
<.5 \\
<.5 \\
<.5\end{array}$ & $\begin{array}{l}<.5 \\
<.5 \\
<.5 \\
<.5 \\
<.5\end{array}$ & $\begin{array}{l}<.5 \\
<.5 \\
<.5 \\
<.5 \\
<.5\end{array}$ & $\begin{array}{l}<.5 \\
<.5 \\
<.5 \\
<.5 \\
<.5\end{array}$ & $\begin{array}{l}<.5 \\
<.5 \\
<.5 \\
<.5 \\
<.5\end{array}$ & $\begin{array}{l}<.5 \\
<.5 \\
<.5 \\
<.5 \\
<.5\end{array}$ & $\begin{array}{l}<.5 \\
<.5 \\
<.5 \\
<.5 \\
<.5\end{array}$ & $\begin{array}{l}<.5 \\
<.5 \\
<.5 \\
<.5 \\
<.5\end{array}$ \\
\hline $\begin{array}{l}\text { Trip blank } \\
\text { Trip blank } \\
\text { Trip blank } \\
\text { Trip blank } \\
\text { Equipment blank }\end{array}$ & $\begin{array}{l}09-28-95 \\
11-07-95 \\
11-21-95 \\
11-28-95 \\
09-11-96\end{array}$ & $\begin{array}{l}<.5 \\
<.5 \\
<.5 \\
<.5 \\
<.5\end{array}$ & $\begin{array}{l}<.5 \\
<.5 \\
<.5 \\
<.5 \\
<.5\end{array}$ & $\begin{array}{l}<.5 \\
<.5 \\
<.5 \\
<.5 \\
<.5\end{array}$ & $\begin{array}{l}<.5 \\
<.5 \\
<.5 \\
<.5 \\
<.5\end{array}$ & $\begin{array}{l}<.5 \\
<.5 \\
<.5 \\
<.5 \\
<.5\end{array}$ & $\begin{array}{l}<.5 \\
<.5 \\
<.5 \\
<.5 \\
<.5\end{array}$ & $\begin{array}{l}<.5 \\
<.5 \\
<.5 \\
<.5 \\
<.5\end{array}$ & $\begin{array}{l}<.5 \\
<.5 \\
<.5 \\
<.5 \\
<.5\end{array}$ & $\begin{array}{l}<.5 \\
<.5 \\
<.5 \\
<.5 \\
<.5\end{array}$ & $\begin{array}{l}<.5 \\
<.5 \\
<.5 \\
<.5 \\
<.5\end{array}$ \\
\hline $\begin{array}{l}\text { Field blank } \\
\text { Field blank } \\
\text { Trip blank } \\
\text { Field blank } \\
\text { Trip blank }\end{array}$ & $\begin{array}{l}09-17-96 \\
09-18-96 \\
09-17-96 \\
09-19-96 \\
09-18-96\end{array}$ & $\begin{array}{l}<.5 \\
<.5 \\
<.5 \\
<.5 \\
<.5\end{array}$ & $\begin{array}{l}<.5 \\
<.5 \\
<.5 \\
<.5 \\
<.5\end{array}$ & $\begin{array}{l}<.5 \\
<.5 \\
<.5 \\
<.5 \\
<.5\end{array}$ & $\begin{array}{l}<.5 \\
<.5 \\
<.5 \\
<.5 \\
<.5\end{array}$ & $\begin{array}{l}<.5 \\
<.5 \\
<.5 \\
<.5 \\
<.5\end{array}$ & $\begin{array}{l}<.5 \\
<.5 \\
<.5 \\
<.5 \\
<.5\end{array}$ & $\begin{array}{l}<.5 \\
<.5 \\
<.5 \\
<.5 \\
<.5\end{array}$ & $\begin{array}{l}<.5 \\
<.5 \\
<.5 \\
<.5 \\
<.5\end{array}$ & $\begin{array}{l}<.5 \\
<.5 \\
<.5 \\
<.5 \\
<.5\end{array}$ & $\begin{array}{l}<.5 \\
<.5 \\
<.5 \\
<.5 \\
<.5\end{array}$ \\
\hline $\begin{array}{l}\text { Trip blank } \\
\text { Field blank } \\
\text { Trip blank } \\
\text { Field blank } \\
\text { Field blank }\end{array}$ & $\begin{array}{l}09-23-96 \\
09-24-96 \\
09-24-96 \\
09-25-96 \\
09-26-96\end{array}$ & $\begin{array}{l}<.5 \\
<.5 \\
<.5 \\
<.5 \\
<.5\end{array}$ & $\begin{array}{l}<.5 \\
<.5 \\
<.5 \\
<.5 \\
<.5\end{array}$ & $\begin{array}{l}<.5 \\
<.5 \\
<.5 \\
<.5 \\
<.5\end{array}$ & $\begin{array}{l}<.5 \\
<.5 \\
<.5 \\
<.5 \\
<.5\end{array}$ & $\begin{array}{l}<.5 \\
<.5 \\
<.5 \\
<.5 \\
<.5\end{array}$ & $\begin{array}{l}<.5 \\
<.5 \\
<.5 \\
<.5 \\
<.5\end{array}$ & $\begin{array}{l}<.5 \\
<.5 \\
<.5 \\
<.5 \\
<.5\end{array}$ & $\begin{array}{l}<.5 \\
<.5 \\
<.5 \\
<.5 \\
<.5\end{array}$ & $\begin{array}{l}<.5 \\
<.5 \\
<.5 \\
<.5 \\
<.5\end{array}$ & $\begin{array}{l}<.5 \\
<.5 \\
<.5 \\
<.5 \\
<.5\end{array}$ \\
\hline $\begin{array}{l}\text { Trip blank } \\
\text { Field blank } \\
\text { Field blank } \\
\text { Trip blank } \\
\text { Field blank }\end{array}$ & $\begin{array}{l}10-01-96 \\
10-01-96 \\
10-02-96 \\
10-04-96 \\
10-04-96\end{array}$ & $\begin{array}{l}<.5 \\
<.5 \\
<.5 \\
<.5 \\
<.5\end{array}$ & $\begin{array}{l}<.5 \\
<.5 \\
<.5 \\
<.5 \\
<.5\end{array}$ & $\begin{array}{l}<.5 \\
<.5 \\
<.5 \\
<.5 \\
<.5\end{array}$ & $\begin{array}{l}<.5 \\
<.5 \\
<.5 \\
<.5 \\
<.5\end{array}$ & $\begin{array}{l}<.5 \\
<.5 \\
<.5 \\
<.5 \\
<.5\end{array}$ & $\begin{array}{l}<.5 \\
<.5 \\
<.5 \\
<.5 \\
<.5\end{array}$ & $\begin{array}{l}<.5 \\
<.5 \\
<.5 \\
<.5 \\
<.5\end{array}$ & $\begin{array}{l}<.5 \\
<.5 \\
<.5 \\
<.5 \\
<.5\end{array}$ & $\begin{array}{l}<.5 \\
<.5 \\
<.5 \\
<.5 \\
<.5\end{array}$ & $\begin{array}{l}<.5 \\
<.5 \\
<.5 \\
<.5 \\
<.5\end{array}$ \\
\hline $\begin{array}{l}\text { Trip blank } \\
\text { Field blank } \\
\text { Field blank } \\
\text { Field blank } \\
\text { Trip blank }\end{array}$ & $\begin{array}{l}10-07-96 \\
10-07-96 \\
10-08-96 \\
10-09-96 \\
10-09-96\end{array}$ & $\begin{array}{l}<.5 \\
<.5 \\
<.5 \\
<.5 \\
<.5\end{array}$ & $\begin{array}{l}<.5 \\
<.5 \\
<.5 \\
<.5 \\
<.5\end{array}$ & $\begin{array}{l}<.5 \\
<.5 \\
<.5 \\
<.5 \\
<.5\end{array}$ & $\begin{array}{l}<.5 \\
<.5 \\
<.5 \\
<.5 \\
<.5\end{array}$ & $\begin{array}{l}<.5 \\
<.5 \\
<.5 \\
<.5 \\
<.5\end{array}$ & $\begin{array}{l}<.5 \\
<.5 \\
<.5 \\
<.5 \\
<.5\end{array}$ & $\begin{array}{l}<.5 \\
<.5 \\
<.5 \\
<.5 \\
<.5\end{array}$ & $\begin{array}{l}<.5 \\
<.5 \\
<.5 \\
<.5 \\
<.5\end{array}$ & $\begin{array}{l}<.5 \\
<.5 \\
<.5 \\
<.5 \\
<.5\end{array}$ & $\begin{array}{l}<.5 \\
<.5 \\
<.5 \\
<.5 \\
<.5\end{array}$ \\
\hline Field blank & $10-10-96$ & $<.5$ & $<.5$ & $<.5$ & $<.5$ & $<.5$ & $<.5$ & $<.5$ & $<.5$ & $<.5$ & $<.5$ \\
\hline
\end{tabular}


Appendix 5. Results of analyses of quality-assurance blank samples for selected organic compounds, 1993-96--Continued

\begin{tabular}{|c|c|c|c|c|c|c|c|c|c|c|c|}
\hline Sample type & Date & $\begin{array}{l}\text { 1,2-Dichloro- } \\
\text { benzene } \\
\text { (o-chloro- } \\
\text { benzene }\end{array}$ & $\begin{array}{l}\text { 1.3-Dichloro- } \\
\text { benzene }\end{array}$ & $\begin{array}{l}\text { 1,4-Dichloro- } \\
\text { benzene }\end{array}$ & $\begin{array}{l}\text { Dichloro- } \\
\text { difluoro- } \\
\text { methane }\end{array}$ & $\begin{array}{l}\text { 1,1-Dichloro- } \\
\text { ethane }\end{array}$ & $\begin{array}{l}\text { 1,2-Dichloro- } \\
\text { ethane }\end{array}$ & $\begin{array}{l}\text { 1,1-Dichloro- } \\
\text { ethylene }\end{array}$ & $\begin{array}{l}\text { cis-1,2- } \\
\text { Dichloro- } \\
\text { ethene }\end{array}$ & $\begin{array}{l}\text { trans-1,2- } \\
\text { Dichloro- } \\
\text { ethene }\end{array}$ & $\begin{array}{l}\text { 1,2-Dichloro- } \\
\text { propane }\end{array}$ \\
\hline $\begin{array}{l}\text { Field blank } \\
\text { Field blank } \\
\text { Trip blank } \\
\text { Trip blank } \\
\text { Field blank }\end{array}$ & $\begin{array}{l}08-19-93 \\
08-25-93 \\
08-19-93 \\
09-14-93 \\
07-06-94\end{array}$ & $\begin{array}{l}<0.5 \\
<.5 \\
<.5 \\
<.5 \\
<.5\end{array}$ & $\begin{array}{l}<0.5 \\
<.5 \\
<.5 \\
<.5 \\
<.5\end{array}$ & $\begin{array}{l}<0.5 \\
<.5 \\
<.5 \\
<.5 \\
<.5\end{array}$ & $\begin{array}{l}<0.5 \\
<.5 \\
<.5 \\
<.5 \\
<.5\end{array}$ & $\begin{array}{l}<0.5 \\
<.5 \\
<.5 \\
<.5 \\
<.5\end{array}$ & $\begin{array}{l}<0.5 \\
<.5 \\
<.5 \\
<.5 \\
<.5\end{array}$ & $\begin{array}{l}<0.5 \\
<.5 \\
<.5 \\
<.5 \\
<.5\end{array}$ & $\begin{array}{l}<0.5 \\
<.5 \\
<.5 \\
<.5 \\
<.5\end{array}$ & $\begin{array}{l}<0.5 \\
<.5 \\
<.5 \\
<.5 \\
<.5\end{array}$ & $\begin{array}{l}<0.5 \\
<.5 \\
<.5 \\
<.5 \\
<.5\end{array}$ \\
\hline $\begin{array}{l}\text { Field blank } \\
\text { Field blank } \\
\text { Field blank } \\
\text { Field blank } \\
\text { Trip blank }\end{array}$ & $\begin{array}{l}07-08-94 \\
07-12-94 \\
07-14-94 \\
07-15-94 \\
07-06-94\end{array}$ & $\begin{array}{l}<.5 \\
<.5 \\
<.5 \\
<.5 \\
<.5\end{array}$ & $\begin{array}{l}<.5 \\
<.5 \\
<.5 \\
<.5 \\
<.5\end{array}$ & $\begin{array}{l}<.5 \\
<.5 \\
<.5 \\
<.5 \\
<.5\end{array}$ & $\begin{array}{l}<.5 \\
<.5 \\
<.5 \\
<.5 \\
<.5\end{array}$ & $\begin{array}{l}<.5 \\
<.5 \\
<.5 \\
<.5 \\
<.5\end{array}$ & $\begin{array}{l}<.5 \\
<.5 \\
<.5 \\
<.5 \\
<.5\end{array}$ & $\begin{array}{l}<.5 \\
<.5 \\
<.5 \\
<.5 \\
<.5\end{array}$ & $\begin{array}{l}<.5 \\
<.5 \\
<.5 \\
<.5 \\
<.5\end{array}$ & $\begin{array}{l}<.5 \\
<.5 \\
<.5 \\
<.5 \\
<.5\end{array}$ & $\begin{array}{l}<.5 \\
<.5 \\
<.5 \\
<.5 \\
<.5\end{array}$ \\
\hline $\begin{array}{l}\text { Trip blank } \\
\text { Trip blank } \\
\text { Trip blank } \\
\text { Field blank } \\
\text { Trip blank }\end{array}$ & $\begin{array}{l}07-08-94 \\
07-12-94 \\
07-14-94 \\
01-19-95 \\
01-18-95\end{array}$ & $\begin{array}{l}<.5 \\
<.5 \\
<.5 \\
<.5 \\
<.5\end{array}$ & $\begin{array}{l}<.5 \\
<.5 \\
<.5 \\
<.5 \\
<.5\end{array}$ & $\begin{array}{l}<.5 \\
<.5 \\
<.5 \\
<.5 \\
<.5\end{array}$ & $\begin{array}{l}<.5 \\
<.5 \\
<.5 \\
<.5 \\
<.5\end{array}$ & $\begin{array}{l}<.5 \\
<.5 \\
<.5 \\
<.5 \\
<.5\end{array}$ & $\begin{array}{l}<.5 \\
<.5 \\
<.5 \\
<.5 \\
<.5\end{array}$ & $\begin{array}{l}<.5 \\
<.5 \\
<.5 \\
<.5 \\
<.5\end{array}$ & $\begin{array}{l}<.5 \\
<.5 \\
<.5 \\
<.5 \\
<.5\end{array}$ & $\begin{array}{l}<.5 \\
<.5 \\
<.5 \\
<.5 \\
<.5\end{array}$ & $\begin{array}{l}<.5 \\
<.5 \\
<.5 \\
<.5 \\
<.5\end{array}$ \\
\hline $\begin{array}{l}\text { Equipment blank } \\
\text { Field blank } \\
\text { Field blank } \\
\text { Field blank } \\
\text { Field blank }\end{array}$ & $\begin{array}{l}08-23-95 \\
09-19-95 \\
09-20-95 \\
09-21-95 \\
09-26-95\end{array}$ & $\begin{array}{l}<.5 \\
<.5 \\
<.5 \\
<.5 \\
<.5\end{array}$ & $\begin{array}{l}<.5 \\
<.5 \\
<.5 \\
<.5 \\
<.5\end{array}$ & $\begin{array}{l}<.5 \\
<.5 \\
<.5 \\
<.5 \\
<.5\end{array}$ & $\begin{array}{l}<.5 \\
<.5 \\
<.5 \\
<.5 \\
<.5\end{array}$ & $\begin{array}{l}<.5 \\
<.5 \\
<.5 \\
<.5 \\
<.5\end{array}$ & $\begin{array}{l}<.5 \\
<.5 \\
<.5 \\
<.5 \\
<.5\end{array}$ & $\begin{array}{l}<.5 \\
<.5 \\
<.5 \\
<.5 \\
<.5\end{array}$ & $\begin{array}{l}<.5 \\
<.5 \\
<.5 \\
<.5 \\
<.5\end{array}$ & $\begin{array}{l}<.5 \\
<.5 \\
<.5 \\
<.5 \\
<.5\end{array}$ & $\begin{array}{l}<.5 \\
<.5 \\
<.5 \\
<.5 \\
<.5\end{array}$ \\
\hline $\begin{array}{l}\text { Field blank } \\
\text { Field blank } \\
\text { Field blank } \\
\text { Field blank } \\
\text { Field blank }\end{array}$ & $\begin{array}{l}09-28-95 \\
11-08-95 \\
11-21-95 \\
11-22-95 \\
11-28-95\end{array}$ & $\begin{array}{l}<.5 \\
<.5 \\
<.5 \\
<.5 \\
<.5\end{array}$ & $\begin{array}{l}<.5 \\
<.5 \\
<.5 \\
<.5 \\
<.5\end{array}$ & $\begin{array}{l}<.5 \\
<.5 \\
<.5 \\
<.5 \\
<.5\end{array}$ & $\begin{array}{l}<.5 \\
<.5 \\
<.5 \\
<.5 \\
<.5\end{array}$ & $\begin{array}{l}<.5 \\
<.5 \\
<.5 \\
<.5 \\
<.5\end{array}$ & $\begin{array}{l}<.5 \\
<.5 \\
<.5 \\
<.5 \\
<.5\end{array}$ & $\begin{array}{l}<.5 \\
<.5 \\
<.5 \\
<.5 \\
<.5\end{array}$ & $\begin{array}{l}<.5 \\
<.5 \\
<.5 \\
<.5 \\
<.5\end{array}$ & $\begin{array}{l}<.5 \\
<.5 \\
<.5 \\
<.5 \\
<.5\end{array}$ & $\begin{array}{l}<.5 \\
<.5 \\
<.5 \\
<.5 \\
<.5\end{array}$ \\
\hline $\begin{array}{l}\text { Field blank } \\
\text { Trip blank } \\
\text { Trip blank } \\
\text { Trip blank } \\
\text { Trip blank }\end{array}$ & $\begin{array}{l}11-29-95 \\
09-19-95 \\
09-20-95 \\
09-22-95 \\
09-25-95\end{array}$ & $\begin{array}{l}<.5 \\
<.5 \\
<.5 \\
<.5 \\
<.5\end{array}$ & $\begin{array}{l}<.5 \\
<.5 \\
<.5 \\
<.5 \\
<.5\end{array}$ & $\begin{array}{l}<.5 \\
<.5 \\
<.5 \\
<.5 \\
<.5\end{array}$ & $\begin{array}{l}<.5 \\
<.5 \\
<.5 \\
<.5 \\
<.5\end{array}$ & $\begin{array}{l}<.5 \\
<.5 \\
<.5 \\
<.5 \\
<.5\end{array}$ & $\begin{array}{l}<.5 \\
<.5 \\
<.5 \\
<.5 \\
<.5\end{array}$ & $\begin{array}{l}<.5 \\
<.5 \\
<.5 \\
<.5 \\
<.5\end{array}$ & $\begin{array}{l}<.5 \\
<.5 \\
<.5 \\
<.5 \\
<.5\end{array}$ & $\begin{array}{l}<.5 \\
<.5 \\
<.5 \\
<.5 \\
<.5\end{array}$ & $\begin{array}{l}<.5 \\
<.5 \\
<.5 \\
<.5 \\
<.5\end{array}$ \\
\hline $\begin{array}{l}\text { Trip blank } \\
\text { Trip blank } \\
\text { Trip blank } \\
\text { Trip blank } \\
\text { Equipment blank }\end{array}$ & $\begin{array}{l}09-28-95 \\
11-07-95 \\
11-21-95 \\
11-28-95 \\
09-11-96\end{array}$ & $\begin{array}{l}<.5 \\
<.5 \\
<.5 \\
<.5 \\
<.5\end{array}$ & $\begin{array}{l}<.5 \\
<.5 \\
<.5 \\
<.5 \\
<.5\end{array}$ & $\begin{array}{l}<.5 \\
<.5 \\
<.5 \\
<.5 \\
<.5\end{array}$ & $\begin{array}{l}<.5 \\
<.5 \\
<.5 \\
<.5 \\
<.5\end{array}$ & $\begin{array}{l}<.5 \\
<.5 \\
<.5 \\
<.5 \\
<.5\end{array}$ & $\begin{array}{l}<.5 \\
<.5 \\
<.5 \\
<.5 \\
<.5\end{array}$ & $\begin{array}{l}<.5 \\
<.5 \\
<.5 \\
<.5 \\
<.5\end{array}$ & $\begin{array}{l}<.5 \\
<.5 \\
<.5 \\
<.5 \\
<.5\end{array}$ & $\begin{array}{l}<.5 \\
<.5 \\
<.5 \\
<.5 \\
<.5\end{array}$ & $\begin{array}{l}<.5 \\
<.5 \\
<.5 \\
<.5 \\
<.5\end{array}$ \\
\hline $\begin{array}{l}\text { Field blank } \\
\text { Field blank } \\
\text { Trip blank } \\
\text { Field blank } \\
\text { Trip blank }\end{array}$ & $\begin{array}{l}09-17-96 \\
09-18-96 \\
09-17-96 \\
09-19-96 \\
09-18-96\end{array}$ & $\begin{array}{l}<.5 \\
<.5 \\
<.5 \\
<.5 \\
<.5\end{array}$ & $\begin{array}{l}<.5 \\
<.5 \\
<.5 \\
<.5 \\
<.5\end{array}$ & $\begin{array}{l}<.5 \\
<.5 \\
<.5 \\
<.5 \\
<.5\end{array}$ & $\begin{array}{l}<.5 \\
<.5 \\
<.5 \\
<.5 \\
<.5\end{array}$ & $\begin{array}{l}<.5 \\
<.5 \\
<.5 \\
<.5 \\
<.5\end{array}$ & $\begin{array}{l}<.5 \\
<.5 \\
<.5 \\
<.5 \\
<.5\end{array}$ & $\begin{array}{l}<.5 \\
<.5 \\
<.5 \\
<.5 \\
<.5\end{array}$ & $\begin{array}{l}<.5 \\
<.5 \\
<.5 \\
<.5 \\
<.5\end{array}$ & $\begin{array}{l}<.5 \\
<.5 \\
<.5 \\
<.5 \\
<.5\end{array}$ & $\begin{array}{l}<.5 \\
<.5 \\
<.5 \\
<.5 \\
<.5\end{array}$ \\
\hline $\begin{array}{l}\text { Trip blank } \\
\text { Field blank } \\
\text { Trip blank } \\
\text { Field blank } \\
\text { Field blank }\end{array}$ & $\begin{array}{l}09-23-96 \\
09-24-96 \\
09-24-96 \\
09-25-96 \\
09-26-96\end{array}$ & $\begin{array}{l}<.5 \\
<.5 \\
<.5 \\
<.5 \\
<.5\end{array}$ & $\begin{array}{l}<.5 \\
<.5 \\
<.5 \\
<.5 \\
<.5\end{array}$ & $\begin{array}{l}<.5 \\
<.5 \\
<.5 \\
<.5 \\
<.5\end{array}$ & $\begin{array}{l}<.5 \\
<.5 \\
<.5 \\
<.5 \\
<.5\end{array}$ & $\begin{array}{l}<.5 \\
<.5 \\
<.5 \\
<.5 \\
<.5\end{array}$ & $\begin{array}{l}<.5 \\
<.5 \\
<.5 \\
<.5 \\
<.5\end{array}$ & $\begin{array}{l}<.5 \\
<.5 \\
<.5 \\
<.5 \\
<.5\end{array}$ & $\begin{array}{l}<.5 \\
<.5 \\
<.5 \\
<.5 \\
<.5\end{array}$ & $\begin{array}{l}<.5 \\
<.5 \\
<.5 \\
<.5 \\
<.5\end{array}$ & $\begin{array}{l}<.5 \\
<.5 \\
<.5 \\
<.5 \\
<.5\end{array}$ \\
\hline $\begin{array}{l}\text { Trip blank } \\
\text { Field blank } \\
\text { Field blank } \\
\text { Trip blank } \\
\text { Field blank }\end{array}$ & $\begin{array}{l}10-01-96 \\
10-01-96 \\
10-02-96 \\
10-04-96 \\
10-04-96\end{array}$ & $\begin{array}{l}<.5 \\
<.5 \\
<.5 \\
<.5 \\
<.5\end{array}$ & $\begin{array}{l}<.5 \\
<.5 \\
<.5 \\
<.5 \\
<.5\end{array}$ & $\begin{array}{l}<.5 \\
<.5 \\
<.5 \\
<.5 \\
<.5\end{array}$ & $\begin{array}{l}<.5 \\
<.5 \\
<.5 \\
<.5 \\
<.5\end{array}$ & $\begin{array}{l}<.5 \\
<.5 \\
<.5 \\
<.5 \\
<.5\end{array}$ & $\begin{array}{l}<.5 \\
<.5 \\
<.5 \\
<.5 \\
<.5\end{array}$ & $\begin{array}{l}<.5 \\
<.5 \\
<.5 \\
<.5 \\
<.5\end{array}$ & $\begin{array}{l}<.5 \\
<.5 \\
<.5 \\
<.5 \\
<.5\end{array}$ & $\begin{array}{l}<.5 \\
<.5 \\
<.5 \\
<.5 \\
<.5\end{array}$ & $\begin{array}{r}<.5 \\
<.5 \\
<.5 \\
.6 \\
<.5\end{array}$ \\
\hline $\begin{array}{l}\text { Trip blank } \\
\text { Field blank } \\
\text { Field blank } \\
\text { Field blank } \\
\text { Trip blank }\end{array}$ & $\begin{array}{l}10-07-96 \\
10-07-96 \\
10-08-96 \\
10-09-96 \\
10-09-96\end{array}$ & $\begin{array}{l}<.5 \\
<.5 \\
<.5 \\
<.5 \\
<.5\end{array}$ & $\begin{array}{l}<.5 \\
<.5 \\
<.5 \\
<.5 \\
<.5\end{array}$ & $\begin{array}{l}<.5 \\
<.5 \\
<.5 \\
<.5 \\
<.5\end{array}$ & $\begin{array}{l}<.5 \\
<.5 \\
<.5 \\
<.5 \\
<.5\end{array}$ & $\begin{array}{l}<.5 \\
<.5 \\
<.5 \\
<.5 \\
<.5\end{array}$ & $\begin{array}{l}<.5 \\
<.5 \\
<.5 \\
<.5 \\
<.5\end{array}$ & $\begin{array}{l}<.5 \\
<.5 \\
<.5 \\
<.5 \\
<.5\end{array}$ & $\begin{array}{l}<.5 \\
<.5 \\
<.5 \\
<.5 \\
<.5\end{array}$ & $\begin{array}{l}<.5 \\
<.5 \\
<.5 \\
<.5 \\
<.5\end{array}$ & $\begin{array}{l}<.5 \\
<.5 \\
<.5 \\
<.5 \\
<.5\end{array}$ \\
\hline Field blank & $10-10-96$ & $<.5$ & $<.5$ & $<.5$ & $<.5$ & $<.5$ & $<.5$ & $<.5$ & $<.5$ & $<.5$ & $<.5$ \\
\hline
\end{tabular}


Appendix 5. Results of analyses of quality-assurance blank samples for selected organic compounds, 1993-96--Continued

\begin{tabular}{|c|c|c|c|c|c|c|c|c|c|c|c|}
\hline Sample type & Date & $\begin{array}{l}\text { 1,3-Dichloro- } \\
\text { propane }\end{array}$ & $\begin{array}{l}\text { 2,2-Dichloro- } \\
\text { propane }\end{array}$ & $\begin{array}{l}\text { 1,1-Dichloro- } \\
\text { propene }\end{array}$ & $\begin{array}{l}\text { cis-1,3- } \\
\text { Dichloro- } \\
\text { propene }\end{array}$ & $\begin{array}{l}\text { trans-1,3- } \\
\text { Dichloro- } \\
\text { propene }\end{array}$ & $\begin{array}{l}\text { Ethyl- } \\
\text { benzene }\end{array}$ & $\begin{array}{l}\text { Hexachloro- } \\
\text { butadiene }\end{array}$ & $\begin{array}{l}\text { Isopropyl- } \\
\text { benzene }\end{array}$ & $\begin{array}{l}\text { 4-lsopropyl- } \\
\text { toluene } \\
\text { (p-Isopropyl- } \\
\text { toluene) }\end{array}$ & $\begin{array}{l}\text { Methylene } \\
\text { chloride }\end{array}$ \\
\hline $\begin{array}{l}\text { Field blank } \\
\text { Field blank } \\
\text { Trip blank } \\
\text { Trip blank } \\
\text { Field blank }\end{array}$ & $\begin{array}{l}08-19-93 \\
08-25-93 \\
08-19-93 \\
09-14-93 \\
07-06-94\end{array}$ & $\begin{array}{l}<0.5 \\
<.5 \\
<.5 \\
<.5 \\
<.5\end{array}$ & $\begin{array}{l}<0.5 \\
<.5 \\
<.5 \\
<.5 \\
<.5\end{array}$ & $\begin{array}{l}<0.5 \\
<.5 \\
<.5 \\
<.5 \\
<.5\end{array}$ & $\begin{array}{l}<0.5 \\
<.5 \\
<.5 \\
<.5 \\
<.5\end{array}$ & $\begin{array}{l}<0.5 \\
<.5 \\
<.5 \\
<.5 \\
<.5\end{array}$ & $\begin{array}{l}<0.5 \\
<.5 \\
<.5 \\
<.5 \\
<.5\end{array}$ & $\begin{array}{l}<0.5 \\
<.5 \\
<.5 \\
<.5 \\
<.5\end{array}$ & $\begin{array}{l}<0.5 \\
<.5 \\
<.5 \\
<.5 \\
<.5\end{array}$ & $\begin{array}{l}<0.5 \\
<.5 \\
<.5 \\
<.5 \\
<.5\end{array}$ & $\begin{aligned} &< 0.5 \\
& .81 \\
&<.5 \\
&<.5 \\
&<.5\end{aligned}$ \\
\hline $\begin{array}{l}\text { Field blank } \\
\text { Field blank } \\
\text { Field blank } \\
\text { Field blank } \\
\text { Trip blank }\end{array}$ & $\begin{array}{l}07-08-94 \\
07-12-94 \\
07-14-94 \\
07-15-94 \\
07-06-94\end{array}$ & $\begin{array}{l}<.5 \\
<.5 \\
<.5 \\
<.5 \\
<.5\end{array}$ & $\begin{array}{l}<.5 \\
<.5 \\
<.5 \\
<.5 \\
<.5\end{array}$ & $\begin{array}{l}<.5 \\
<.5 \\
<.5 \\
<.5 \\
<.5\end{array}$ & $\begin{array}{l}<.5 \\
<.5 \\
<.5 \\
<.5 \\
<.5\end{array}$ & $\begin{array}{l}<.5 \\
<.5 \\
<.5 \\
<.5 \\
<.5\end{array}$ & $\begin{array}{l}<.5 \\
<.5 \\
<.5 \\
<.5 \\
<.5\end{array}$ & $\begin{array}{l}<.5 \\
<.5 \\
<.5 \\
<.5 \\
<.5\end{array}$ & $\begin{array}{l}<.5 \\
<.5 \\
<.5 \\
<.5 \\
<.5\end{array}$ & $\begin{array}{l}<.5 \\
<.5 \\
<.5 \\
<.5 \\
<.5\end{array}$ & $\begin{array}{l}<.5 \\
.54 \\
2.50 \\
1.20 \\
<.5\end{array}$ \\
\hline $\begin{array}{l}\text { Trip blank } \\
\text { Trip blank } \\
\text { Trip blank } \\
\text { Field blank } \\
\text { Trip blank }\end{array}$ & $\begin{array}{l}07-08-94 \\
07-12-94 \\
07-14-94 \\
01-19-95 \\
01-18-95\end{array}$ & $\begin{array}{l}<.5 \\
<.5 \\
<.5 \\
<.5 \\
<.5\end{array}$ & $\begin{array}{l}<.5 \\
<.5 \\
<.5 \\
<.5 \\
<.5\end{array}$ & $\begin{array}{l}<.5 \\
<.5 \\
<.5 \\
<.5 \\
<.5\end{array}$ & $\begin{array}{l}<.5 \\
<.5 \\
<.5 \\
<.5 \\
<.5\end{array}$ & $\begin{array}{l}<.5 \\
<.5 \\
<.5 \\
<.5 \\
<.5\end{array}$ & $\begin{array}{l}<.5 \\
<.5 \\
<.5 \\
<.5 \\
<.5\end{array}$ & $\begin{array}{l}<.5 \\
<.5 \\
<.5 \\
<.5 \\
<.5\end{array}$ & $\begin{array}{l}<.5 \\
<.5 \\
<.5 \\
<.5 \\
<.5\end{array}$ & $\begin{array}{l}<.5 \\
<.5 \\
<.5 \\
<.5 \\
<.5\end{array}$ & $\begin{array}{l}<.5 \\
2.40 \\
1.40 \\
<.5 \\
1.0\end{array}$ \\
\hline $\begin{array}{l}\text { Equipment blank } \\
\text { Field blank } \\
\text { Field blank } \\
\text { Field blank } \\
\text { Field blank }\end{array}$ & $\begin{array}{l}08-23-95 \\
09-19-95 \\
09-20-95 \\
09-21-95 \\
09-26-95\end{array}$ & $\begin{array}{l}<.5 \\
<.5 \\
<.5 \\
<.5 \\
<.5\end{array}$ & $\begin{array}{l}<.5 \\
<.5 \\
<.5 \\
<.5 \\
<.5\end{array}$ & $\begin{array}{l}<.5 \\
<.5 \\
<.5 \\
<.5 \\
<.5\end{array}$ & $\begin{array}{l}<.5 \\
<.5 \\
<.5 \\
<.5 \\
<.5\end{array}$ & $\begin{array}{l}<.5 \\
<.5 \\
<.5 \\
<.5 \\
<.5\end{array}$ & $\begin{array}{l}<.5 \\
<.5 \\
<.5 \\
<.5 \\
<.5\end{array}$ & $\begin{array}{l}<.5 \\
<.5 \\
<.5 \\
<.5 \\
<.5\end{array}$ & $\begin{array}{l}<.5 \\
<.5 \\
<.5 \\
<.5 \\
<.5\end{array}$ & $\begin{array}{l}<.5 \\
<.5 \\
<.5 \\
<.5 \\
<.5\end{array}$ & $\begin{array}{l}<.5 \\
<.5 \\
<.5 \\
<.5 \\
<.5\end{array}$ \\
\hline $\begin{array}{l}\text { Field blank } \\
\text { Field blank } \\
\text { Field blank } \\
\text { Field blank } \\
\text { Field blank }\end{array}$ & $\begin{array}{l}09-28-95 \\
11-08-95 \\
11-21-95 \\
11-22-95 \\
11-28-95\end{array}$ & $\begin{array}{l}<.5 \\
<.5 \\
<.5 \\
<.5 \\
<.5\end{array}$ & $\begin{array}{l}<.5 \\
<.5 \\
<.5 \\
<.5 \\
<.5\end{array}$ & $\begin{array}{l}<.5 \\
<.5 \\
<.5 \\
<.5 \\
<.5\end{array}$ & $\begin{array}{l}<.5 \\
<.5 \\
<.5 \\
<.5 \\
<.5\end{array}$ & $\begin{array}{l}<.5 \\
<.5 \\
<.5 \\
<.5 \\
<.5\end{array}$ & $\begin{array}{l}<.5 \\
<.5 \\
<.5 \\
<.5 \\
<.5\end{array}$ & $\begin{array}{l}<.5 \\
<.5 \\
<.5 \\
<.5 \\
<.5\end{array}$ & $\begin{array}{l}<.5 \\
<.5 \\
<.5 \\
<.5 \\
<.5\end{array}$ & $\begin{array}{l}<.5 \\
<.5 \\
<.5 \\
<.5 \\
<.5\end{array}$ & $\begin{array}{l}<.5 \\
<.5 \\
<.5 \\
<.5 \\
<.5\end{array}$ \\
\hline $\begin{array}{l}\text { Field blank } \\
\text { Trip blank } \\
\text { Trip blank } \\
\text { Trip blank } \\
\text { Trip blank }\end{array}$ & $\begin{array}{l}11-29-95 \\
09-19-95 \\
09-20-95 \\
09-22-95 \\
09-25-95\end{array}$ & $\begin{array}{l}<.5 \\
<.5 \\
<.5 \\
<.5 \\
<.5\end{array}$ & $\begin{array}{l}<.5 \\
<.5 \\
<.5 \\
<.5 \\
<.5\end{array}$ & $\begin{array}{l}<.5 \\
<.5 \\
<.5 \\
<.5 \\
<.5\end{array}$ & $\begin{array}{l}<.5 \\
<.5 \\
<.5 \\
<.5 \\
<.5\end{array}$ & $\begin{array}{l}<.5 \\
<.5 \\
<.5 \\
<.5 \\
<.5\end{array}$ & $\begin{array}{l}<.5 \\
<.5 \\
<.5 \\
<.5 \\
<.5\end{array}$ & $\begin{array}{l}<.5 \\
<.5 \\
<.5 \\
<.5 \\
<.5\end{array}$ & $\begin{array}{l}<.5 \\
<.5 \\
<.5 \\
<.5 \\
<.5\end{array}$ & $\begin{array}{l}<.5 \\
<.5 \\
<.5 \\
<.5 \\
<.5\end{array}$ & $\begin{array}{r}\quad .9 \\
<.5 \\
<.5 \\
<.5 \\
<.5\end{array}$ \\
\hline $\begin{array}{l}\text { Trip blank } \\
\text { Trip blank } \\
\text { Trip blank } \\
\text { Trip blank } \\
\text { Equipment blank }\end{array}$ & $\begin{array}{l}09-28-95 \\
11-07-95 \\
11-21-95 \\
11-28-95 \\
09-11-96\end{array}$ & $\begin{array}{l}<.5 \\
<.5 \\
<.5 \\
<.5 \\
<.5\end{array}$ & $\begin{array}{l}<.5 \\
<.5 \\
<.5 \\
<.5 \\
<.5\end{array}$ & $\begin{array}{l}<.5 \\
<.5 \\
<.5 \\
<.5 \\
<.5\end{array}$ & $\begin{array}{l}<.5 \\
<.5 \\
<.5 \\
<.5 \\
<.5\end{array}$ & $\begin{array}{l}<.5 \\
<.5 \\
<.5 \\
<.5 \\
<.5\end{array}$ & $\begin{array}{l}<.5 \\
<.5 \\
<.5 \\
<.5 \\
<.5\end{array}$ & $\begin{array}{l}<.5 \\
<.5 \\
<.5 \\
<.5 \\
<.5\end{array}$ & $\begin{array}{l}<.5 \\
<.5 \\
<.5 \\
<.5 \\
<.5\end{array}$ & $\begin{array}{l}<.5 \\
<.5 \\
<.5 \\
<.5 \\
<.5\end{array}$ & $\begin{array}{l}<.5 \\
<.5 \\
<.5 \\
<.5 \\
<.5\end{array}$ \\
\hline $\begin{array}{l}\text { Field blank } \\
\text { Field blank } \\
\text { Trip blank } \\
\text { Field blank } \\
\text { Trip blank }\end{array}$ & $\begin{array}{l}09-17-96 \\
09-18-96 \\
09-17-96 \\
09-19-96 \\
09-18-96\end{array}$ & $\begin{array}{l}<.5 \\
<.5 \\
<.5 \\
<.5 \\
<.5\end{array}$ & $\begin{array}{l}<.5 \\
<.5 \\
<.5 \\
<.5 \\
<.5\end{array}$ & $\begin{array}{l}<.5 \\
<.5 \\
<.5 \\
<.5 \\
<.5\end{array}$ & $\begin{array}{l}<.5 \\
<.5 \\
<.5 \\
<.5 \\
<.5\end{array}$ & $\begin{array}{l}<.5 \\
<.5 \\
<.5 \\
<.5 \\
<.5\end{array}$ & $\begin{array}{l}<.5 \\
<.5 \\
<.5 \\
<.5 \\
<.5\end{array}$ & $\begin{array}{l}<.5 \\
<.5 \\
<.5 \\
<.5 \\
<.5\end{array}$ & $\begin{array}{l}<.5 \\
<.5 \\
<.5 \\
<.5 \\
<.5\end{array}$ & $\begin{array}{l}<.5 \\
<.5 \\
<.5 \\
<.5 \\
<.5\end{array}$ & $\begin{array}{l}<.5 \\
<.5 \\
<.5 \\
.7 \\
<.5\end{array}$ \\
\hline $\begin{array}{l}\text { Trip blank } \\
\text { Field blank } \\
\text { Trip blank } \\
\text { Field blank } \\
\text { Field blank }\end{array}$ & $\begin{array}{l}09-23-96 \\
09-24-96 \\
09-24-96 \\
09-25-96 \\
09-26-96\end{array}$ & $\begin{array}{l}<.5 \\
<.5 \\
<.5 \\
<.5 \\
<.5\end{array}$ & $\begin{array}{l}<.5 \\
<.5 \\
<.5 \\
<.5 \\
<.5\end{array}$ & $\begin{array}{l}<.5 \\
<.5 \\
<.5 \\
<.5 \\
<.5\end{array}$ & $\begin{array}{l}<.5 \\
<.5 \\
<.5 \\
<.5 \\
<.5\end{array}$ & $\begin{array}{l}<.5 \\
<.5 \\
<.5 \\
<.5 \\
<.5\end{array}$ & $\begin{array}{l}<.5 \\
<.5 \\
<.5 \\
<.5 \\
<.5\end{array}$ & $\begin{array}{l}<.5 \\
<.5 \\
<.5 \\
<.5 \\
<.5\end{array}$ & $\begin{array}{l}<.5 \\
<.5 \\
<.5 \\
<.5 \\
<.5\end{array}$ & $\begin{array}{l}<.5 \\
<.5 \\
<.5 \\
<.5 \\
<.5\end{array}$ & $\begin{array}{l}1.5 \\
<.5 \\
2.0 \\
6.3 \\
4.5\end{array}$ \\
\hline $\begin{array}{l}\text { Trip blank } \\
\text { Field blank } \\
\text { Field blank } \\
\text { Trip blank } \\
\text { Field blank }\end{array}$ & $\begin{array}{l}10-01-96 \\
10-01-96 \\
10-02-96 \\
10-04-96 \\
10-04-96\end{array}$ & $\begin{array}{l}<.5 \\
<.5 \\
<.5 \\
<.5 \\
<.5\end{array}$ & $\begin{array}{l}<.5 \\
<.5 \\
<.5 \\
<.5 \\
<.5\end{array}$ & $\begin{array}{l}<.5 \\
<.5 \\
<.5 \\
<.5 \\
<.5\end{array}$ & $\begin{array}{l}<.5 \\
<.5 \\
<.5 \\
<.5 \\
<.5\end{array}$ & $\begin{array}{l}<.5 \\
<.5 \\
<.5 \\
<.5 \\
<.5\end{array}$ & $\begin{array}{l}<.5 \\
<.5 \\
<.5 \\
<.5 \\
<.5\end{array}$ & $\begin{array}{l}<.5 \\
<.5 \\
<.5 \\
<.5 \\
<.5\end{array}$ & $\begin{array}{l}<.5 \\
<.5 \\
<.5 \\
<.5 \\
<.5\end{array}$ & $\begin{array}{l}<.5 \\
<.5 \\
<.5 \\
<.5 \\
<.5\end{array}$ & $\begin{array}{r}.8 \\
<.5 \\
1.4 \\
1.3 \\
2.6\end{array}$ \\
\hline $\begin{array}{l}\text { Trip blank } \\
\text { Field blank } \\
\text { Field blank } \\
\text { Field blank } \\
\text { Trip blank }\end{array}$ & $\begin{array}{l}10-07-96 \\
10-07-96 \\
10-08-96 \\
10-09-96 \\
10-09-96\end{array}$ & $\begin{array}{l}<.5 \\
<.5 \\
<.5 \\
<.5 \\
<.5\end{array}$ & $\begin{array}{l}<.5 \\
<.5 \\
<.5 \\
<.5 \\
<.5\end{array}$ & $\begin{array}{l}<.5 \\
<.5 \\
<.5 \\
<.5 \\
<.5\end{array}$ & $\begin{array}{l}<.5 \\
<.5 \\
<.5 \\
<.5 \\
<.5\end{array}$ & $\begin{array}{l}<.5 \\
<.5 \\
<.5 \\
<.5 \\
<.5\end{array}$ & $\begin{array}{l}<.5 \\
<.5 \\
<.5 \\
<.5 \\
<.5\end{array}$ & $\begin{array}{l}<.5 \\
<.5 \\
<.5 \\
<.5 \\
<.5\end{array}$ & $\begin{array}{l}<.5 \\
<.5 \\
<.5 \\
<.5 \\
<.5\end{array}$ & $\begin{array}{l}<.5 \\
<.5 \\
<.5 \\
<.5 \\
<.5\end{array}$ & $\begin{array}{r}.9 \\
1.0 \\
<.5 \\
3.0 \\
5.8\end{array}$ \\
\hline Field blank & $10-10-96$ & $<.5$ & $<.5$ & $<.5$ & $<.5$ & $<.5$ & $<.5$ & $<.5$ & $<.5$ & $<.5$ & 3.9 \\
\hline
\end{tabular}


Appendix 5. Results of analyses of quality-assurance blank samples for selected organic compounds, 1993-96--Continued

\begin{tabular}{|c|c|c|c|c|c|c|c|c|c|c|c|}
\hline Sample type & Date & Naphthalene & $\begin{array}{l}\text { N-propyl- } \\
\text { benzene }\end{array}$ & Styrene & $\begin{array}{l}1,1,1,2- \\
\text { Tetrachloro- } \\
\text { ethane }\end{array}$ & $\begin{array}{l}1,1,2,2-\text { Tetra- } \\
\text { chloro- } \\
\text { ethane }\end{array}$ & $\begin{array}{l}\text { Tetrachloro- } \\
\text { ethene }\end{array}$ & Toluene & $\begin{array}{l}1,2,3- \\
\text { Trichloroben } \\
\text { zene }\end{array}$ & $\begin{array}{l}1,2,4- \\
\text { Trichloro- } \\
\text { benzene }\end{array}$ & $\begin{array}{l}1,1,1- \\
\text { Trichloro- } \\
\text { ethane }\end{array}$ \\
\hline $\begin{array}{l}\text { Field blank } \\
\text { Field blank } \\
\text { Trip blank } \\
\text { Trip blank } \\
\text { Field blank }\end{array}$ & $\begin{array}{l}08-19-93 \\
08-25-93 \\
08-19-93 \\
09-14-93 \\
07-06-94\end{array}$ & $\begin{array}{l}<0.5 \\
<.5 \\
<.5 \\
<.5 \\
<.5\end{array}$ & $\begin{array}{l}<0.5 \\
<.5 \\
<.5 \\
<.5 \\
<.5\end{array}$ & $\begin{array}{l}<0.5 \\
<.5 \\
<.5 \\
<.5 \\
<.5\end{array}$ & $\begin{array}{l}<0.5 \\
<.5 \\
<.5 \\
<.5 \\
<.5\end{array}$ & $\begin{array}{l}<0.5 \\
<.5 \\
<.5 \\
<.5 \\
<.5\end{array}$ & $\begin{array}{l}<0.5 \\
<.5 \\
<.5 \\
<.5 \\
<.5\end{array}$ & $\begin{array}{l}<0.5 \\
<.5 \\
<.5 \\
<.5 \\
<.5\end{array}$ & $\begin{array}{l}<0.5 \\
<.5 \\
<.5 \\
<.5 \\
<.5\end{array}$ & $\begin{array}{l}<0.5 \\
<.5 \\
<.5 \\
<.5 \\
<.5\end{array}$ & $\begin{array}{l}<0.5 \\
<.5 \\
<.5 \\
<.5 \\
<.5\end{array}$ \\
\hline $\begin{array}{l}\text { Field blank } \\
\text { Field blank } \\
\text { Field blank } \\
\text { Field blank } \\
\text { Trip blank }\end{array}$ & $\begin{array}{l}07-08-94 \\
07-12-94 \\
07-14-94 \\
07-15-94 \\
07-06-94\end{array}$ & $\begin{array}{l}<.5 \\
<.5 \\
<.5 \\
<.5 \\
<.5\end{array}$ & $\begin{array}{l}<.5 \\
<.5 \\
<.5 \\
<.5 \\
<.5\end{array}$ & $\begin{array}{l}<.5 \\
<.5 \\
<.5 \\
<.5 \\
<.5\end{array}$ & $\begin{array}{l}<.5 \\
<.5 \\
<.5 \\
<.5 \\
<.5\end{array}$ & $\begin{array}{l}<.5 \\
<.5 \\
<.5 \\
<.5 \\
<.5\end{array}$ & $\begin{array}{l}<.5 \\
<.5 \\
<.5 \\
<.5 \\
<.5\end{array}$ & $\begin{array}{l}<.5 \\
<.5 \\
<.5 \\
<.5 \\
<.5\end{array}$ & $\begin{array}{l}<.5 \\
<.5 \\
<.5 \\
<.5 \\
<.5\end{array}$ & $\begin{array}{l}<.5 \\
<.5 \\
<.5 \\
<.5 \\
<.5\end{array}$ & $\begin{array}{l}<.5 \\
<.5 \\
<.5 \\
<.5 \\
<.5\end{array}$ \\
\hline $\begin{array}{l}\text { Trip blank } \\
\text { Trip blank } \\
\text { Trip blank } \\
\text { Field blank } \\
\text { Trip blank }\end{array}$ & $\begin{array}{l}07-08-94 \\
07-12-94 \\
07-14-94 \\
01-19-95 \\
01-18-95\end{array}$ & $\begin{array}{l}<.5 \\
<.5 \\
<.5 \\
<.5 \\
<.5\end{array}$ & $\begin{array}{l}<.5 \\
<.5 \\
<.5 \\
<.5 \\
<.5\end{array}$ & $\begin{array}{l}<.5 \\
<.5 \\
<.5 \\
<.5 \\
<.5\end{array}$ & $\begin{array}{l}<.5 \\
<.5 \\
<.5 \\
<.5 \\
<.5\end{array}$ & $\begin{array}{l}<.5 \\
<.5 \\
<.5 \\
<.5 \\
<.5\end{array}$ & $\begin{array}{l}<.5 \\
<.5 \\
<.5 \\
<.5 \\
<.5\end{array}$ & $\begin{array}{l}<.5 \\
<.5 \\
<.5 \\
<.5 \\
<.5\end{array}$ & $\begin{array}{l}<.5 \\
<.5 \\
<.5 \\
<.5 \\
<.5\end{array}$ & $\begin{array}{l}<.5 \\
<.5 \\
<.5 \\
<.5 \\
<.5\end{array}$ & $\begin{array}{l}<.5 \\
<.5 \\
<.5 \\
<.5 \\
<.5\end{array}$ \\
\hline $\begin{array}{l}\text { Equipment blank } \\
\text { Field blank } \\
\text { Field blank } \\
\text { Field blank } \\
\text { Field blank }\end{array}$ & $\begin{array}{l}08-23-95 \\
09-19-95 \\
09-20-95 \\
09-21-95 \\
09-26-95\end{array}$ & $\begin{array}{l}<.5 \\
<.5 \\
<.5 \\
<.5 \\
<.5\end{array}$ & $\begin{array}{l}<.5 \\
<.5 \\
<.5 \\
<.5 \\
<.5\end{array}$ & $\begin{array}{l}<.5 \\
<.5 \\
<.5 \\
<.5 \\
<.5\end{array}$ & $\begin{array}{l}<.5 \\
<.5 \\
<.5 \\
<.5 \\
<.5\end{array}$ & $\begin{array}{l}<.5 \\
<.5 \\
<.5 \\
<.5 \\
<.5\end{array}$ & $\begin{array}{l}<.5 \\
<.5 \\
<.5 \\
<.5 \\
<.5\end{array}$ & $\begin{array}{l}<.5 \\
<.5 \\
<.5 \\
<.5 \\
<.5\end{array}$ & $\begin{array}{l}<.5 \\
<.5 \\
<.5 \\
<.5 \\
<.5\end{array}$ & $\begin{array}{l}<.5 \\
<.5 \\
<.5 \\
<.5 \\
<.5\end{array}$ & $\begin{array}{l}<.5 \\
<.5 \\
<.5 \\
<.5 \\
<.5\end{array}$ \\
\hline $\begin{array}{l}\text { Field blank } \\
\text { Field blank } \\
\text { Field blank } \\
\text { Field blank } \\
\text { Field blank }\end{array}$ & $\begin{array}{l}09-28-95 \\
11-08-95 \\
11-21-95 \\
11-22-95 \\
11-28-95\end{array}$ & $\begin{array}{l}<.5 \\
<.5 \\
<.5 \\
<.5 \\
<.5\end{array}$ & $\begin{array}{l}<.5 \\
<.5 \\
<.5 \\
<.5 \\
<.5\end{array}$ & $\begin{array}{l}<.5 \\
<.5 \\
<.5 \\
<.5 \\
<.5\end{array}$ & $\begin{array}{l}<.5 \\
<.5 \\
<.5 \\
<.5 \\
<.5\end{array}$ & $\begin{array}{l}<.5 \\
<.5 \\
<.5 \\
<.5 \\
<.5\end{array}$ & $\begin{array}{l}<.5 \\
<.5 \\
<.5 \\
<.5 \\
<.5\end{array}$ & $\begin{array}{l}<.5 \\
<.5 \\
<.5 \\
<.5 \\
<.5\end{array}$ & $\begin{array}{l}<.5 \\
<.5 \\
<.5 \\
<.5 \\
<.5\end{array}$ & $\begin{array}{l}<.5 \\
<.5 \\
<.5 \\
<.5 \\
<.5\end{array}$ & $\begin{array}{l}<.5 \\
<.5 \\
<.5 \\
<.5 \\
<.5\end{array}$ \\
\hline $\begin{array}{l}\text { Field blank } \\
\text { Trip blank } \\
\text { Trip blank } \\
\text { Trip blank } \\
\text { Trip blank }\end{array}$ & $\begin{array}{l}11-29-95 \\
09-19-95 \\
09-20-95 \\
09-22-95 \\
09-25-95\end{array}$ & $\begin{array}{l}<.5 \\
<.5 \\
<.5 \\
<.5 \\
<.5\end{array}$ & $\begin{array}{l}<.5 \\
<.5 \\
<.5 \\
<.5 \\
<.5\end{array}$ & $\begin{array}{l}<.5 \\
<.5 \\
<.5 \\
<.5 \\
<.5\end{array}$ & $\begin{array}{l}<.5 \\
<.5 \\
<.5 \\
<.5 \\
<.5\end{array}$ & $\begin{array}{l}<.5 \\
<.5 \\
<.5 \\
<.5 \\
<.5\end{array}$ & $\begin{array}{l}<.5 \\
<.5 \\
<.5 \\
<.5 \\
<.5\end{array}$ & $\begin{array}{l}<.5 \\
<.5 \\
<.5 \\
<.5 \\
<.5\end{array}$ & $\begin{array}{l}<.5 \\
<.5 \\
<.5 \\
<.5 \\
<.5\end{array}$ & $\begin{array}{l}<.5 \\
<.5 \\
<.5 \\
<.5 \\
<.5\end{array}$ & $\begin{array}{l}<.5 \\
<.5 \\
<.5 \\
<.5 \\
<.5\end{array}$ \\
\hline $\begin{array}{l}\text { Trip blank } \\
\text { Trip blank } \\
\text { Trip blank } \\
\text { Trip blank } \\
\text { Equipment blank }\end{array}$ & $\begin{array}{l}09-28-95 \\
11-07-95 \\
11-21-95 \\
11-28-95 \\
09-11-96\end{array}$ & $\begin{array}{l}<.5 \\
<.5 \\
<.5 \\
<.5 \\
<.5\end{array}$ & $\begin{array}{l}<.5 \\
<.5 \\
<.5 \\
<.5 \\
<.5\end{array}$ & $\begin{array}{l}<.5 \\
<.5 \\
<.5 \\
<.5 \\
<.5\end{array}$ & $\begin{array}{l}<.5 \\
<.5 \\
<.5 \\
<.5 \\
<.5\end{array}$ & $\begin{array}{l}<.5 \\
<.5 \\
<.5 \\
<.5 \\
<.5\end{array}$ & $\begin{array}{l}<.5 \\
<.5 \\
<.5 \\
<.5 \\
<.5\end{array}$ & $\begin{array}{l}<.5 \\
<.5 \\
<.5 \\
<.5 \\
<.5\end{array}$ & $\begin{array}{l}<.5 \\
<.5 \\
<.5 \\
<.5 \\
<.5\end{array}$ & $\begin{array}{l}<.5 \\
<.5 \\
<.5 \\
<.5 \\
<.5\end{array}$ & $\begin{array}{l}<.5 \\
<.5 \\
<.5 \\
<.5 \\
<.5\end{array}$ \\
\hline $\begin{array}{l}\text { Field blank } \\
\text { Field blank } \\
\text { Trip blank } \\
\text { Field blank } \\
\text { Trip blank }\end{array}$ & $\begin{array}{l}09-17-96 \\
09-18-96 \\
09-17-96 \\
09-19-96 \\
09-18-96\end{array}$ & $\begin{array}{l}<.5 \\
<.5 \\
<.5 \\
<.5 \\
<.5\end{array}$ & $\begin{array}{l}<.5 \\
<.5 \\
<.5 \\
<.5 \\
<.5\end{array}$ & $\begin{array}{l}<.5 \\
<.5 \\
<.5 \\
<.5 \\
<.5\end{array}$ & $\begin{array}{l}<.5 \\
<.5 \\
<.5 \\
<.5 \\
<.5\end{array}$ & $\begin{array}{l}<.5 \\
<.5 \\
<.5 \\
<.5 \\
<.5\end{array}$ & $\begin{array}{l}<.5 \\
<.5 \\
<.5 \\
<.5 \\
<.5\end{array}$ & $\begin{array}{l}<.5 \\
<.5 \\
<.5 \\
<.5 \\
<.5\end{array}$ & $\begin{array}{l}<.5 \\
<.5 \\
<.5 \\
<.5 \\
<.5\end{array}$ & $\begin{array}{l}<.5 \\
<.5 \\
<.5 \\
<.5 \\
<.5\end{array}$ & $\begin{array}{l}<.5 \\
<.5 \\
<.5 \\
<.5 \\
<.5\end{array}$ \\
\hline $\begin{array}{l}\text { Trip blank } \\
\text { Field blank } \\
\text { Trip blank } \\
\text { Field blank } \\
\text { Field blank }\end{array}$ & $\begin{array}{l}09-23-96 \\
09-24-96 \\
09-24-96 \\
09-25-96 \\
09-26-96\end{array}$ & $\begin{array}{l}<.5 \\
<.5 \\
<.5 \\
<.5 \\
<.5\end{array}$ & $\begin{array}{l}<.5 \\
<.5 \\
<.5 \\
<.5 \\
<.5\end{array}$ & $\begin{array}{l}<.5 \\
<.5 \\
<.5 \\
<.5 \\
<.5\end{array}$ & $\begin{array}{l}<.5 \\
<.5 \\
<.5 \\
<.5 \\
<.5\end{array}$ & $\begin{array}{l}<.5 \\
<.5 \\
<.5 \\
<.5 \\
<.5\end{array}$ & $\begin{array}{l}<.5 \\
<.5 \\
<.5 \\
<.5 \\
<.5\end{array}$ & $\begin{array}{l}<.5 \\
<.5 \\
<.5 \\
<.5 \\
<.5\end{array}$ & $\begin{array}{l}<.5 \\
<.5 \\
<.5 \\
<.5 \\
<.5\end{array}$ & $\begin{array}{l}<.5 \\
<.5 \\
<.5 \\
<.5 \\
<.5\end{array}$ & $\begin{array}{l}<.5 \\
<.5 \\
<.5 \\
<.5 \\
<.5\end{array}$ \\
\hline $\begin{array}{l}\text { Trip blank } \\
\text { Field blank } \\
\text { Field blank } \\
\text { Trip blank } \\
\text { Field blank }\end{array}$ & $\begin{array}{l}10-01-96 \\
10-01-96 \\
10-02-96 \\
10-04-96 \\
10-04-96\end{array}$ & $\begin{array}{l}<.5 \\
<.5 \\
<.5 \\
<.5 \\
<.5\end{array}$ & $\begin{array}{l}<.5 \\
<.5 \\
<.5 \\
<.5 \\
<.5\end{array}$ & $\begin{array}{l}<.5 \\
<.5 \\
<.5 \\
<.5 \\
<.5\end{array}$ & $\begin{array}{l}<.5 \\
<.5 \\
<.5 \\
<.5 \\
<.5\end{array}$ & $\begin{array}{l}<.5 \\
<.5 \\
<.5 \\
<.5 \\
<.5\end{array}$ & $\begin{array}{l}<.5 \\
<.5 \\
<.5 \\
<.5 \\
<.5\end{array}$ & $\begin{array}{l}<.5 \\
<.5 \\
<.5 \\
<.5 \\
<.5\end{array}$ & $\begin{array}{l}<.5 \\
<.5 \\
<.5 \\
<.5 \\
<.5\end{array}$ & $\begin{array}{l}<.5 \\
<.5 \\
<.5 \\
<.5 \\
<.5\end{array}$ & $\begin{array}{l}<.5 \\
<.5 \\
<.5 \\
<.5 \\
<.5\end{array}$ \\
\hline $\begin{array}{l}\text { Trip blank } \\
\text { Field blank } \\
\text { Field blank } \\
\text { Field blank } \\
\text { Trip blank }\end{array}$ & $\begin{array}{l}10-07-96 \\
10-07-96 \\
10-08-96 \\
10-09-96 \\
10-09-96\end{array}$ & $\begin{array}{l}<.5 \\
<.5 \\
<.5 \\
<.5 \\
<.5\end{array}$ & $\begin{array}{l}<.5 \\
<.5 \\
<.5 \\
<.5 \\
<.5\end{array}$ & $\begin{array}{l}<.5 \\
<.5 \\
<.5 \\
<.5 \\
<.5\end{array}$ & $\begin{array}{l}<.5 \\
<.5 \\
<.5 \\
<.5 \\
<.5\end{array}$ & $\begin{array}{l}<.5 \\
<.5 \\
<.5 \\
<.5 \\
<.5\end{array}$ & $\begin{array}{l}<.5 \\
<.5 \\
<.5 \\
<.5 \\
<.5\end{array}$ & $\begin{array}{l}<.5 \\
<.5 \\
<.5 \\
<.5 \\
<.5\end{array}$ & $\begin{array}{l}<.5 \\
<.5 \\
<.5 \\
<.5 \\
<.5\end{array}$ & $\begin{array}{l}<.5 \\
<.5 \\
<.5 \\
<.5 \\
<.5\end{array}$ & $\begin{array}{l}<.5 \\
<.5 \\
<.5 \\
<.5 \\
<.5\end{array}$ \\
\hline Field blank & $10-10-96$ & $<.5$ & $<.5$ & $<.5$ & $<.5$ & $<.5$ & $<.5$ & $<.5$ & $<.5$ & $<.5$ & $<.5$ \\
\hline
\end{tabular}


Appendix 5. Results of analyses of quality-assurance blank samples for selected organic compounds, 1993-96--Continued

\begin{tabular}{|c|c|c|c|c|c|c|c|c|c|c|}
\hline Sample type & Date & $\begin{array}{l}1,1,2- \\
\text { Trichloro- } \\
\text { ethane }\end{array}$ & $\begin{array}{l}\text { Trichloro- } \\
\text { ethene }\end{array}$ & $\begin{array}{l}\text { Trichloro- } \\
\text { fluoro- } \\
\text { methane }\end{array}$ & $\begin{array}{l}\text { 1,2,3- } \\
\text { Trichloro- } \\
\text { propane }\end{array}$ & $\begin{array}{l}\text { 1,2,4-Tri- } \\
\text { methyl- } \\
\text { benzene }\end{array}$ & $\begin{array}{l}\text { 1,3,5-Tri- } \\
\text { methyl- } \\
\text { benzene }\end{array}$ & $\begin{array}{l}\text { Vinyl } \\
\text { chloride }\end{array}$ & 0-Xylene & $\begin{array}{l}\text { meta/para- } \\
\text { Xylene }\end{array}$ \\
\hline $\begin{array}{l}\text { Field blank } \\
\text { Field blank } \\
\text { Trip blank } \\
\text { Trip blank } \\
\text { Field blank }\end{array}$ & $\begin{array}{l}08-19-93 \\
08-25-93 \\
08-19-93 \\
09-14-93 \\
07-06-94\end{array}$ & $\begin{array}{l}<0.5 \\
<.5 \\
<.5 \\
<.5 \\
<.5\end{array}$ & $\begin{array}{l}<0.5 \\
<.5 \\
<.5 \\
<.5 \\
<.5\end{array}$ & $\begin{array}{l}<0.5 \\
<.5 \\
<.5 \\
<.5 \\
<.5\end{array}$ & $\begin{array}{l}<0.5 \\
<.5 \\
<.5 \\
<.5 \\
<.5\end{array}$ & $\begin{array}{l}<0.5 \\
<.5 \\
<.5 \\
<.5 \\
<.5\end{array}$ & $\begin{array}{l}<0.5 \\
<.5 \\
<.5 \\
<.5 \\
<.5\end{array}$ & $\begin{array}{l}<0.5 \\
<.5 \\
<.5 \\
<.5 \\
<.5\end{array}$ & $\begin{array}{l}<0.5 \\
<.5 \\
<.5 \\
<.5 \\
<.5\end{array}$ & $\begin{array}{l}<0.5 \\
<.5 \\
<.5 \\
<.5 \\
<.5\end{array}$ \\
\hline $\begin{array}{l}\text { Field blank } \\
\text { Field blank } \\
\text { Field blank } \\
\text { Field blank } \\
\text { Trip blank }\end{array}$ & $\begin{array}{l}07-08-94 \\
07-12-94 \\
07-14-94 \\
07-15-94 \\
07-06-94\end{array}$ & $\begin{array}{l}<.5 \\
<.5 \\
<.5 \\
<.5 \\
<.5\end{array}$ & $\begin{array}{l}<.5 \\
<.5 \\
<.5 \\
<.5 \\
<.5\end{array}$ & $\begin{array}{l}<.5 \\
<.5 \\
<.5 \\
<.5 \\
<.5\end{array}$ & $\begin{array}{l}<.5 \\
<.5 \\
<.5 \\
<.5 \\
<.5\end{array}$ & $\begin{array}{l}<.5 \\
<.5 \\
<.5 \\
<.5 \\
<.5\end{array}$ & $\begin{array}{l}<.5 \\
<.5 \\
<.5 \\
<.5 \\
<.5\end{array}$ & $\begin{array}{l}<.5 \\
<.5 \\
<.5 \\
<.5 \\
<.5\end{array}$ & $\begin{array}{l}<.5 \\
<.5 \\
<.5 \\
<.5 \\
<.5\end{array}$ & $\begin{array}{l}<.5 \\
<.5 \\
<.5 \\
<.5 \\
<.5\end{array}$ \\
\hline $\begin{array}{l}\text { Trip blank } \\
\text { Trip blank } \\
\text { Trip blank } \\
\text { Field blank } \\
\text { Trip blank }\end{array}$ & $\begin{array}{l}07-08-94 \\
07-12-94 \\
07-14-94 \\
01-19-95 \\
01-18-95\end{array}$ & $\begin{array}{l}<.5 \\
<.5 \\
<.5 \\
<.5 \\
<.5\end{array}$ & $\begin{array}{l}<.5 \\
<.5 \\
<.5 \\
<.5 \\
<.5\end{array}$ & $\begin{array}{l}<.5 \\
<.5 \\
<.5 \\
<.5 \\
<.5\end{array}$ & $\begin{array}{l}<.5 \\
<.5 \\
<.5 \\
<.5 \\
<.5\end{array}$ & $\begin{array}{l}<.5 \\
<.5 \\
<.5 \\
<.5 \\
<.5\end{array}$ & $\begin{array}{l}<.5 \\
<.5 \\
<.5 \\
<.5 \\
<.5\end{array}$ & $\begin{array}{l}<.5 \\
<.5 \\
<.5 \\
<.5 \\
<.5\end{array}$ & $\begin{array}{l}<.5 \\
<.5 \\
<.5 \\
<.5 \\
<.5\end{array}$ & $\begin{array}{l}<.5 \\
<.5 \\
<.5 \\
<1.0 \\
<1.0\end{array}$ \\
\hline $\begin{array}{l}\text { Equipment blank } \\
\text { Field blank } \\
\text { Field blank } \\
\text { Field blank } \\
\text { Field blank }\end{array}$ & $\begin{array}{l}08-23-95 \\
09-19-95 \\
09-20-95 \\
09-21-95 \\
09-26-95\end{array}$ & $\begin{array}{l}<.5 \\
<.5 \\
<.5 \\
<.5 \\
<.5\end{array}$ & $\begin{array}{l}<.5 \\
<.5 \\
<.5 \\
<.5 \\
<.5\end{array}$ & $\begin{array}{l}<.5 \\
<.5 \\
<.5 \\
<.5 \\
<.5\end{array}$ & $\begin{array}{l}<.5 \\
<.5 \\
<.5 \\
<.5 \\
<.5\end{array}$ & $\begin{array}{l}<.5 \\
<.5 \\
<.5 \\
<.5 \\
<.5\end{array}$ & $\begin{array}{l}<.5 \\
<.5 \\
<.5 \\
<.5 \\
<.5\end{array}$ & $\begin{array}{l}<.5 \\
<.5 \\
<.5 \\
<.5 \\
<.5\end{array}$ & $\begin{array}{l}<.5 \\
<.5 \\
<.5 \\
<.5 \\
<.5\end{array}$ & $\begin{array}{l}<1.0 \\
<1.0 \\
<1.0 \\
<1.0 \\
<1.0\end{array}$ \\
\hline $\begin{array}{l}\text { Field blank } \\
\text { Field blank } \\
\text { Field blank } \\
\text { Field blank } \\
\text { Field blank }\end{array}$ & $\begin{array}{l}09-28-95 \\
11-08-95 \\
11-21-95 \\
11-22-95 \\
11-28-95\end{array}$ & $\begin{array}{l}<.5 \\
<.5 \\
<.5 \\
<.5 \\
<.5\end{array}$ & $\begin{array}{l}<.5 \\
<.5 \\
<.5 \\
<.5 \\
<.5\end{array}$ & $\begin{array}{l}<.5 \\
<.5 \\
<.5 \\
<.5 \\
<.5\end{array}$ & $\begin{array}{l}<.5 \\
<.5 \\
<.5 \\
<.5 \\
<.5\end{array}$ & $\begin{array}{l}<.5 \\
<.5 \\
<.5 \\
<.5 \\
<.5\end{array}$ & $\begin{array}{l}<.5 \\
<.5 \\
<.5 \\
<.5 \\
<.5\end{array}$ & $\begin{array}{l}<.5 \\
<.5 \\
<.5 \\
<.5 \\
<.5\end{array}$ & $\begin{array}{l}<.5 \\
<.5 \\
<.5 \\
<.5 \\
<.5\end{array}$ & $\begin{array}{l}<1.0 \\
<1.0 \\
<1.0 \\
<1.0 \\
<1.0\end{array}$ \\
\hline $\begin{array}{l}\text { Field blank } \\
\text { Trip blank } \\
\text { Trip blank } \\
\text { Trip blank } \\
\text { Trip blank }\end{array}$ & $\begin{array}{l}11-29-95 \\
09-19-95 \\
09-20-95 \\
09-22-95 \\
09-25-95\end{array}$ & $\begin{array}{l}<.5 \\
<.5 \\
<.5 \\
<.5 \\
<.5\end{array}$ & $\begin{array}{l}<.5 \\
<.5 \\
<.5 \\
<.5 \\
<.5\end{array}$ & $\begin{array}{l}<.5 \\
<.5 \\
<.5 \\
<.5 \\
<.5\end{array}$ & $\begin{array}{l}<.5 \\
<.5 \\
<.5 \\
<.5 \\
<.5\end{array}$ & $\begin{array}{l}<.5 \\
<.5 \\
<.5 \\
<.5 \\
<.5\end{array}$ & $\begin{array}{l}<.5 \\
<.5 \\
<.5 \\
<.5 \\
<.5\end{array}$ & $\begin{array}{l}<.5 \\
<.5 \\
<.5 \\
<.5 \\
<.5\end{array}$ & $\begin{array}{l}<.5 \\
<.5 \\
<.5 \\
<.5 \\
<.5\end{array}$ & $\begin{array}{l}<1.0 \\
<1.0 \\
<1.0 \\
<1.0 \\
<1.0\end{array}$ \\
\hline $\begin{array}{l}\text { Trip blank } \\
\text { Trip blank } \\
\text { Trip blank } \\
\text { Trip blank } \\
\text { Equipment blank }\end{array}$ & $\begin{array}{l}09-28-95 \\
11-07-95 \\
11-21-95 \\
11-28-95 \\
09-11-96\end{array}$ & $\begin{array}{l}<.5 \\
<.5 \\
<.5 \\
<.5 \\
<.5\end{array}$ & $\begin{array}{l}<.5 \\
<.5 \\
<.5 \\
<.5 \\
<.5\end{array}$ & $\begin{array}{l}<.5 \\
<.5 \\
<.5 \\
<.5 \\
<.5\end{array}$ & $\begin{array}{l}<.5 \\
<.5 \\
<.5 \\
<.5 \\
<.5\end{array}$ & $\begin{array}{l}<.5 \\
<.5 \\
<.5 \\
<.5 \\
<.5\end{array}$ & $\begin{array}{l}<.5 \\
<.5 \\
<.5 \\
<.5 \\
<.5\end{array}$ & $\begin{array}{l}<.5 \\
<.5 \\
<.5 \\
<.5 \\
<.5\end{array}$ & $\begin{array}{l}<.5 \\
<.5 \\
<.5 \\
<.5 \\
<.5\end{array}$ & $\begin{array}{l}<1.0 \\
<1.0 \\
<1.0 \\
<1.0 \\
<1.0\end{array}$ \\
\hline $\begin{array}{l}\text { Field blank } \\
\text { Field blank } \\
\text { Trip blank } \\
\text { Field blank } \\
\text { Trip blank }\end{array}$ & $\begin{array}{l}09-17-96 \\
09-18-96 \\
09-17-96 \\
09-19-96 \\
09-18-96\end{array}$ & $\begin{array}{l}<.5 \\
<.5 \\
<.5 \\
<.5 \\
<.5\end{array}$ & $\begin{array}{l}<.5 \\
<.5 \\
<.5 \\
<.5 \\
<.5\end{array}$ & $\begin{array}{l}<.5 \\
<.5 \\
<.5 \\
<.5 \\
<.5\end{array}$ & $\begin{array}{l}<.5 \\
<.5 \\
<.5 \\
<.5 \\
<.5\end{array}$ & $\begin{array}{l}<.5 \\
<.5 \\
<.5 \\
<.5 \\
<.5\end{array}$ & $\begin{array}{l}<.5 \\
<.5 \\
<.5 \\
<.5 \\
<.5\end{array}$ & $\begin{array}{l}<.5 \\
<.5 \\
<.5 \\
<.5 \\
<.5\end{array}$ & $\begin{array}{l}<.5 \\
<.5 \\
<.5 \\
<.5 \\
<.5\end{array}$ & $\begin{array}{l}<1.0 \\
<1.0 \\
<1.0 \\
<1.0 \\
<1.0\end{array}$ \\
\hline $\begin{array}{l}\text { Trip blank } \\
\text { Field blank } \\
\text { Trip blank } \\
\text { Field blank } \\
\text { Field blank }\end{array}$ & $\begin{array}{l}09-23-96 \\
09-24-96 \\
09-24-96 \\
09-25-96 \\
09-26-96\end{array}$ & $\begin{array}{l}<.5 \\
<.5 \\
<.5 \\
<.5 \\
<.5\end{array}$ & $\begin{array}{l}<.5 \\
<.5 \\
<.5 \\
<.5 \\
<.5\end{array}$ & $\begin{array}{l}<.5 \\
<.5 \\
<.5 \\
<.5 \\
<.5\end{array}$ & $\begin{array}{l}<.5 \\
<.5 \\
<.5 \\
<.5 \\
<.5\end{array}$ & $\begin{array}{l}<.5 \\
<.5 \\
<.5 \\
<.5 \\
<.5\end{array}$ & $\begin{array}{l}<.5 \\
<.5 \\
<.5 \\
<.5 \\
<.5\end{array}$ & $\begin{array}{l}<.5 \\
<.5 \\
<.5 \\
<.5 \\
<.5\end{array}$ & $\begin{array}{l}<.5 \\
<.5 \\
<.5 \\
<.5 \\
<.5\end{array}$ & $\begin{array}{l}<1.0 \\
<1.0 \\
<1.0 \\
<1.0 \\
<1.0\end{array}$ \\
\hline $\begin{array}{l}\text { Trip blank } \\
\text { Field blank } \\
\text { Field blank } \\
\text { Trip blank } \\
\text { Field blank }\end{array}$ & $\begin{array}{l}10-01-96 \\
10-01-96 \\
10-02-96 \\
10-04-96 \\
10-04-96\end{array}$ & $\begin{array}{l}<.5 \\
<.5 \\
<.5 \\
<.5 \\
<.5\end{array}$ & $\begin{array}{l}<.5 \\
<.5 \\
<.5 \\
<.5 \\
<.5\end{array}$ & $\begin{array}{l}<.5 \\
<.5 \\
<.5 \\
<.5 \\
<.5\end{array}$ & $\begin{array}{l}<.5 \\
<.5 \\
<.5 \\
<.5 \\
<.5\end{array}$ & $\begin{array}{l}<.5 \\
<.5 \\
<.5 \\
<.5 \\
<.5\end{array}$ & $\begin{array}{l}<.5 \\
<.5 \\
<.5 \\
<.5 \\
<.5\end{array}$ & $\begin{array}{l}<.5 \\
<.5 \\
<.5 \\
<.5 \\
<.5\end{array}$ & $\begin{array}{l}<.5 \\
<.5 \\
<.5 \\
<.5 \\
<.5\end{array}$ & $\begin{array}{l}<1.0 \\
<1.0 \\
<1.0 \\
<1.0 \\
<1.0\end{array}$ \\
\hline $\begin{array}{l}\text { Trip blank } \\
\text { Field blank } \\
\text { Field blank } \\
\text { Field blank } \\
\text { Trip blank }\end{array}$ & $\begin{array}{l}10-07-96 \\
10-07-96 \\
10-08-96 \\
10-09-96 \\
10-09-96\end{array}$ & $\begin{array}{l}<.5 \\
<.5 \\
<.5 \\
<.5 \\
<.5\end{array}$ & $\begin{array}{l}<.5 \\
<.5 \\
<.5 \\
<.5 \\
<.5\end{array}$ & $\begin{array}{l}<.5 \\
<.5 \\
<.5 \\
<.5 \\
<.5\end{array}$ & $\begin{array}{l}<.5 \\
<.5 \\
<.5 \\
<.5 \\
<.5\end{array}$ & $\begin{array}{l}<.5 \\
<.5 \\
<.5 \\
<.5 \\
<.5\end{array}$ & $\begin{array}{l}<.5 \\
<.5 \\
<.5 \\
<.5 \\
<.5\end{array}$ & $\begin{array}{l}<.5 \\
<.5 \\
<.5 \\
<.5 \\
<.5\end{array}$ & $\begin{array}{l}<.5 \\
<.5 \\
<.5 \\
<.5 \\
<.5\end{array}$ & $\begin{array}{l}<1.0 \\
<1.0 \\
<1.0 \\
<1.0 \\
<1.0\end{array}$ \\
\hline Field blank & $10-10-96$ & $<.5$ & $<.5$ & $<.5$ & $<.5$ & $<.5$ & $<.5$ & $<.5$ & $<.5$ & $<1.0$ \\
\hline
\end{tabular}

